\author{
UNIVERSIDADE DE SÃO PAULO \\ FACULDADE DE FILOSOFIA, LETRAS E CIÊNCIAS HUMANAS \\ DEPARTAMENTO DE LINGÜÍSTICA \\ PROGRAMA DE PÓS-GRADUAÇÃO EM SEMIÓTICA E LINGÜÍSTICA
}

MAGALI ROSA DE SANT'ANNA

\title{
A PRONÚNCIA DAS CONSOANTES INGLESAS \\ EM FINAL DE VOCÁBULO \\ POR FALANTES BRASILEIROS
}




\author{
UNIVERSIDADE DE SÃO PAULO \\ FACULDADE DE FILOSOFIA, LETRAS E CIÊNCIAS HUMANAS \\ DEPARTAMENTO DE LINGÜÍSTICA \\ PROGRAMA DE PÓS-GRADUAÇÃO EM SEMIÓTICA E LINGÜÍSTICA
}

\title{
A PRONÚNCIA DAS CONSOANTES INGLESAS \\ EM FINAL DE VOCÁBULO \\ POR FALANTES BRASILEIROS
}

Magali Rosa de Sant'Anna

\begin{abstract}
Tese apresentada ao Programa de PósGraduação em Semiótica e Lingüística Geral do Departamento de Lingüística da Faculdade de Filosofia, Letras e Ciências Humanas, da Universidade de São Paulo, para obtenção do título de Doutor em Letras.
\end{abstract}

Orientador(a): Profa. Dra ${ }^{\mathrm{a}}$. Haydée Fiszbein Wertzner

São Paulo

2008 


\section{AUTORIZO A REPRODUCAO E DIVULGACAO TOTAL OU PARCIAL DESTE TRABALHO, POR QUALQUER MEIO CONVENCIONAL OU ELETRONICO, PARA FINS DE ESTUDO E PESQUISA, DESDE QUE CITADA A FONTE.}

Sant'Anna, Magali Rosa de

S223 A pronúncia das consoantes inglesas em final de vocábulos por falantes brasileiros/ Magali Rosa de Sant'Anna; orientadora Haydée Fiszbein Wertzner. -- São Paulo, 2008.

$254 f$.

Tese (Doutorado - Programa de Semiótica e Lingüística Geral. Área de Concentração: Semiótica e Lingüística Geral) Departamento de Lingüística da Faculdade de Filosofia, Letras e Ciências Humanas da Universidade de São Paulo.

1. Aquisição/Aprendizagem de Língua Estrangeira. 2. Fonética contrastiva. 3. Fonologia contrastiva. 4. Lingüística Aplicada. I. Título 


\section{Folha de Aprovação}

\section{Magali Rosa de Sant'Anna}

A Pronúncia das Consoantes Inglesas em Final de Vocábulo por Falantes Brasileiros

Tese apresentada ao Programa de Pós-Graduação do Departamento de Lingüística da Faculdade de Filosofia, Letras e Ciências Humanas da Universidade de São Paulo para obtenção do título de Doutor.

Área de Concentração: Semiótica e Lingüística Geral

Aprovado em:

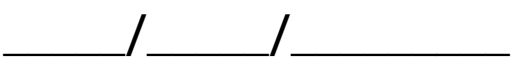

\section{Banca Examinadora}

Prof. Dr.

Instituição: Assinatura:

Prof. Dr.

Instituição:

Assinatura:

Prof. Dr.

Instituição:

Assinatura:

Prof. Dr.

Instituição:

Assinatura:

Prof. Dr.

Instituição:

Assinatura: 
Para meus pais. Por todos os exemplos de amor, respeito, caráter, honestidade e ética. 


\section{Agradecimentos}

Quando conheci a Professora Doutora Haydée Fizsbein Wertzner nas aulas de pós-graduação, não passou pela minha cabeça que pudesse ter o prazer de tê-la como orientadora durante a realização da minha pesquisa para aquisição do título de Doutorado. Foi com grande expectativa, que espero ter atendido, que ela me aceitou como sua orientanda. Aprendi muito com ela e, principalmente, que não se pode deixar de pensar um minuto na pesquisa. Ela esteve presente durante a elaboração do trabalho e sou muito grata por todas as vezes que comentou e acrescentou pontos importantes para que fossem incluídos na Tese, inclusive as orientações e análises estatísticas, as quais muito contribuíram para discussão dos dados coletados. Muito obrigada.

Agradeço a Professora Doutora Sandra Maria Silva Palomo, pelo incentivo em iniciar e concluir essa pesquisa. Ela sempre esteve presente, mesmo que distante, fazendo comentários importantíssimos para a finalização do trabalho. Sua amizade e carinho estarão sempre em meus pensamentos.

Agradeço também as Professoras Doutoras Sandra Maria Silva Palomo e Safa Abou Chahla Jubran que contribuíram para um aprofundamento da pesquisa e pelos valiosos comentários apresentados no Exame de Qualificação, os quais aceitei com muita atenção e espero ter atendido a todas as recomendações e alterações sugeridas.

Aos estudantes, a coordenadora do curso e a professora que me ajudou a coletar os dados dessa pesquisa que tornaram esse trabalho possível, a minha gratidão. Agradeço também a Universidade que possibilitou essa pesquisa.

A maior parte de mim agradece a paciência, a compreensão e o incentivo final da Maitê, minha filha querida. E ao meu companheiro Jair ... espero que você tenha entendido e me perdoado pelas noites ausentes em que estive escrevendo ... Obrigada por vocês acreditarem em mim. 
Agradeço mais uma vez meus pais por terem tentado compreender minha pesquisa e incentivado-a sempre. Cada "bate-papo" me fez perceber o quanto concluí-la também representava um objetivo alcançado por eles.

A minha irmã, Mireili, que esteve presente durante todo percurso, agradeço por todas as vezes que conversamos sobre minha pesquisa. Por toda a ajuda e incentivo. Por estar por perto. Sempre e sempre.

Ao meu cunhado, Paulo Roberto Pedrozo Rocha, por todas as vezes que conversamos sobre a minha pesquisa, pela força e incentivo durante todo o percurso, o que na verdade foi muito além disso, resultou em comentários importantes sobre os mais diferentes aspectos, os quais foram cruciais para a conclusão desta pesquisa.

Não poderia deixar de mencionar a presença constante de uma tia muito querida, tia Cema, que mesmo sem entender do que se tratava a minha pesquisa, sempre perguntou como eu estava me saindo e que eu seria mais uma vez vencedora. Obrigada por você existir e me amar.

Agradeço ainda ao estatístico Carlos Alberto Bezerra da Silva que trabalhou para que eu conseguisse descrever pormenorizadamente os dados da pesquisa. Aprendi muito com sua paciência e calma para resolver os problemas.

Merece também um agradecimento especial dois amigos e irmãos de coração. Um deles me ajudou muito no início do processo para ingresso no programa de Doutorado, com comentários sobre a leitura do meu projeto. Muito obrigada, Odair. O outro, colaborou mais adiante, na elaboração do texto final com sua força, seu incentivo e como não poderia deixar de ser, com sua sabedoria. Você foi muito importante, Rossi.

Agradeço pelo apoio recebido dos amigos em todos os momentos: Márcia, Maria Cláudia, Roseline, Glauco, Lídia, José Luis, Menezes, Jane, entre outros que não cito, mas que também deixaram sua marca nesta pesquisa. 
A linguagem pertence ao mesmo tempo à 'natureza' e à 'mente'. Eugenio Coseriu, 
Sant'Anna, M. R. de - A Pronúncia das Consoantes Inglesas em Final de Vocábulo por Falantes Brasileiros. 2008. 253 f. Tese (Doutorado) - Faculdade de Filosofia, Letras e Ciências Humanas da Universidade de São Paulo. São Paulo, 2008.

A amostra da presente pesquisa foi composta por 45 falantes do português brasileiro que aprendiam inglês como língua estrangeira. Todos foram alunos do ensino superior, do curso de Tradutor, de uma universidade privada da cidade de São Paulo. O objetivo foi analisar a produção das consoantes inglesas em final de vocábulo, nos padrões silábicos, VC e CVC, em dois momentos, com e sem treino. Os resultados evidenciaram mudanças de desempenho na análise póstreino. Foi também verificada a ocorrência de mais erros no padrão VC em função da categoria de erro Vocalização.

Palavras-chave: Aquisição e Aprendizagem de Língua Estrangeira, Fonética Contrastiva, Fonologia Contrastiva, Lingüística Aplicada 


\section{Abstract}

Sant'Anna, M. R. de - The English Consonants Pronunciation at the End of Words by Brazilian Speakers. 2008. 253 f. Thesis (Doutoral) - Faculdade de Filosofia, Letras e Ciências Humanas da Universidade de São Paulo. São Paulo, 2008.

The sample of the present research consisted of 45 Portuguese Brazilian speakers, who were learning English as a foreign language. All of them are attending the Translator course, in a private university, in the city of São Paulo. The aim of this research was to analyze the production of English ending consonants, based on syllabic patterns, VC and CVC, in two different moments, with and without training. It was also verified the occurrence of more errors in the VC pattern related to Vocalization category.

Key-words: Foreign Language Learning and Acquisition, Contrastive Phonetics, Contrastive Phonology, Applied Linguistics 


\section{Lista de Figuras}

Figura 1: Estrutura da Sílaba

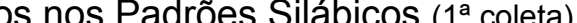

Figura 3: Ocorrência das Categorias de Erros de acordo com os Padrões Silábicos no

Total dos Sujeitos ( $1^{\text {a }}$ coleta)

Figura 4: Porcentagem de Ocorrência de Erros nos Padrões Silábicos ( $2^{\mathrm{a}}$ coleta) .......... 101

Figura 5: Ocorrência das Categorias de Erros de acordo com os Padrões Silábicos no

Total dos Sujeitos ( $2^{\mathrm{a}}$ coleta)

Figura 6: Ocorrências de Erros em VC e CVC ....................................................... 105

Figura 7: Possibilidades de Ocorrências nos Padrões Silábicos, nas Duas Coletas ...... 109

Figura 8: Ocorrência das Categorias de Erros do Padrão Silábico VC no Total dos Sujeitos

Figura 9: Ocorrência das Categorias de Erros do Padrão Silábico CVC no Total dos

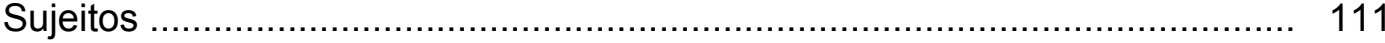

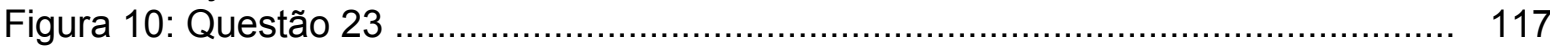

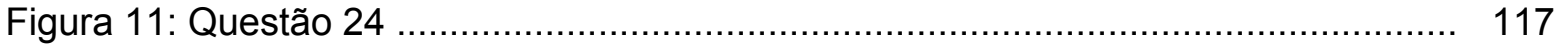

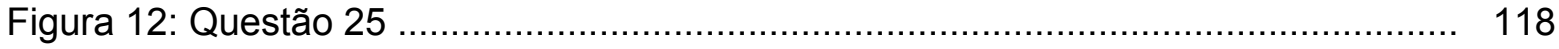

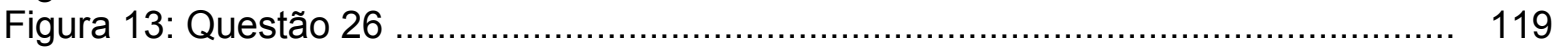

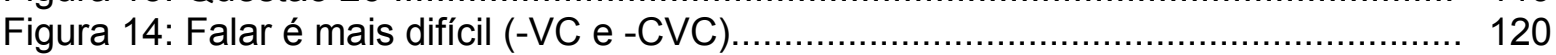

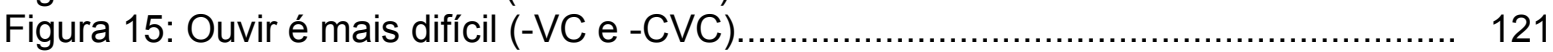

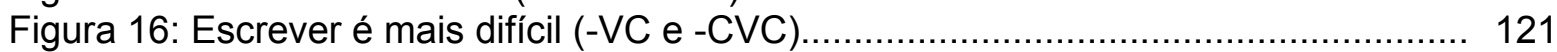

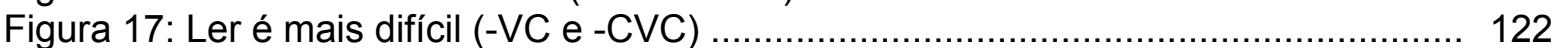

Figura 18: Habilidades Lingüísticas de Maior Dificuldade ....................................... 123 


\section{Lista de Quadros}

Qúla $p$.

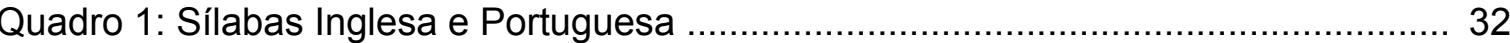

Quadro 2: Sílaba CCVCC Inglesa e Portuguesa ..................................................... 32

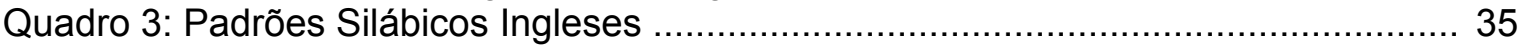

Quadro 4: Padrões Silábicos Portugueses ............................................................. 36

Quadro 5: Contaste dos Padrões Silábicos Ingleses e Portugueses .......................... 38

Quadro 6: Seqüência de Dois Fonemas no Início do Vocábulo Inglês ......................... 40

Quadro 7: Seqüência de Três Fonemas no Início do Vocábulo Inglês ............................ 41

Quadro 8: Seqüência de Fonemas em Final de Vocábulo Simples (Inglês) ...................... 42-43

Quadro 9: Seqüência de Fonemas em Final de Vocábulo com Sufixo Derivacional $\quad 44$ (Inglês)

Quadro 10: Seqüência de Morfemas em Final de Vocábulo com Sufixo Inflexional $\quad 45$ (Inglês)

Quadro 11: Seqüência de Morfemas de Plural dos Substantivos em Final de Vocábulo 46 (Inglês)

Quadro 12: Seqüência de Fonemas em Final de Vocábulo dos Verbos Regulares $\quad 47$ (Inglês)

Quadro 13: Seqüência de Dois Fonemas no Início do Vocábulo Português .................. 49

Quadro 14: Seqüência de Fonemas em Final de Sílaba (Português) ................................ 50

Quadro 15: Seqüência de Fonemas no Início ou no Final de Sílaba (Português) ............... 51

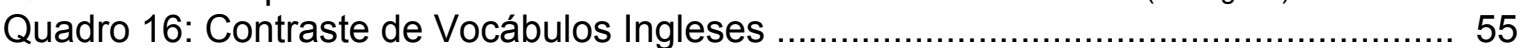

Quadro 17: Contraste dos Verbos Regulares do Inglês.............................................. 56

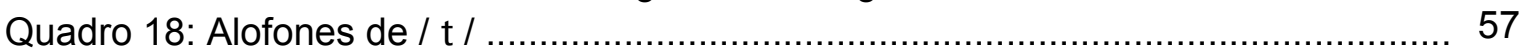

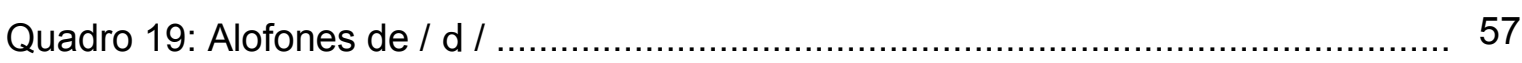

Quadro 20: Processo de Palatização - falantes do inglês ........................................... 58

Quadro 21: Vocábulo Inglês 'fill' - falantes do inglês e do português ...........................60 60

Quadro 22: Vocábulo Inglês 'thin' e 'this' - falantes do inglês e do português ............... 62

Quadro 23: Vocábulo Inglês 'house' - falantes do inglês e do português ....................... 63

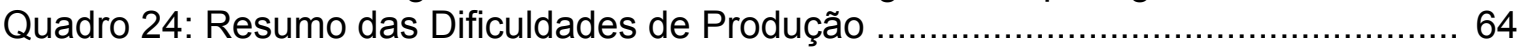

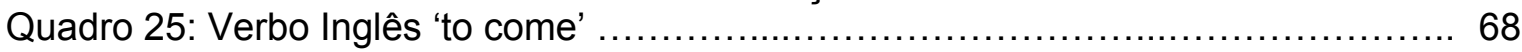

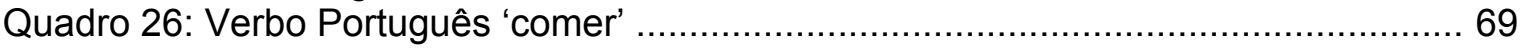

Quadro 27: Transcrição dos Vocábulos 'pickles' e 'apples' ....................................... 81

Quadro 28: Fonemas Vocálicos Finais dos Vocábulos do Texto ................................. 83

Quadro 29: Fonemas Consonantais Finais dos Vocábulos do Texto .......................... 84

Quadro 30: Fonemas Consonantais com Erro - $1^{\text {a }}$ coleta ......................................... 85

Quadro 31: Fonemas Consonantais com Erro - $2^{\text {a }}$ coleta ........................................ 86

Quadro 32: Categorias de Erros, Padrões Silábicos VC e CVC e Vocábulos do Texto.. 90-91

Quadro 33: Categorias de Erros e Padrões Silábicos .............................................. 104 


\section{Lista de Tabelas}

1.: Distribuição dos Sujeitos Segundo Idade e Gênero

Tabela 2: Vocábulos Ingleses (-VC e -CVC) do Texto ................................................ 79

Tabela 3: Possibilidades de Ocorrências na Amostra ................................................. 82

Tabela 4: Número de Vezes que Cada Categoria de Erros Ocorreu na Amostra Total. 91

Tabela 5: Estatística Descritiva Proporcional das Ocorrências de Erros nos Padrões 96

Silábicos $\left(1^{\text {a }}\right.$ coleta $)$

Tabela 6: Ocorrência das Categorias de Erros nos Vocábulos (1a coleta) ............................... 99

Tabela 7: Estatística Descritiva Proporcional das Ocorrências de Erros nos Padrões Silábicos $\left(2^{\mathrm{a}}\right.$ coleta) ..................................................................................... 101

Tabela 8: Ocorrência das Categorias de Erros nos Vocábulos ( $2^{\mathrm{a}}$ coleta) ....................... 102

Tabela 9: Ocorrência de Erros Absolutos nas Coletas ............................................ 106

Tabela 10: Estatística Descritiva dos Erros em Números Absolutos nos Padrões Silábicos - VC e CVC ...................................................................... 107

Tabela 11: Ocorrência Proporcional de Erros nos Padrões Silábicos ......................... 107

Tabela 12: Vocábulos com Erros nas $1^{\mathrm{a}}$ e $2^{\mathrm{a}}$ Coletas ................................................ 108

Tabela 13: Ocorrência das Categorias de Erros nos vocábulos da $1^{\mathrm{a}}$ e $2^{\mathrm{a}}$ coletas ....... 110

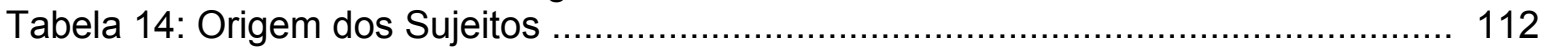

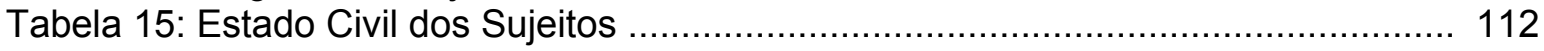

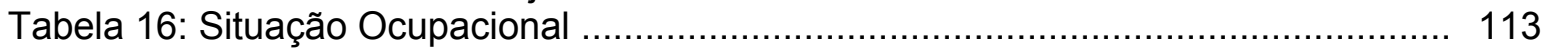

Tabela 17: Tipo de Escola de Ensino Médio ........................................................ 113

Tabela 18: Seqüência dos Estudos ................................................................. 114

Tabela 19: Interesse dos Sujeitos em Aprender Línguas Estrangeiras ....................... 114

Tabela 20: Motivo da Escolha do Curso de Tradutor ............................................... 115

Tabela 21: Motivação para Estudar Língua Inglesa .............................................. 115

Tabela 22: Níveis de Aquisição das Habilidades Lingüísticas ................................ 116

Tabela 23: Nível Estrutural e Pronúncia ............................................................... 116 


\section{Lista de Anexos}

$p$.

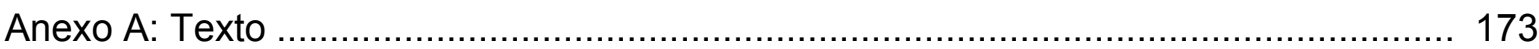

Anexo B: Vocábulos do Texto com a Transcrição da(s) Pronúncia(s) Correta(s) ......... 174

Anexo C: Quadro com Total dos Vocábulos do Texto .............................................. 176

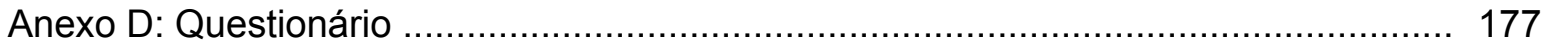

Anexo E: Tabelas com a Articulação Inadequada dos Sujeitos ............................... 181

Anexo F: Tópicos das Aulas de "Pronúncia da Língua Inglesa" ................................ 226

Anexo G: Análise com 'Test T' - Padrão Silábico VC ................................................ 227

Anexo H: Análise com 'Test T' - Padrão Silábico CVC …....................................... 229

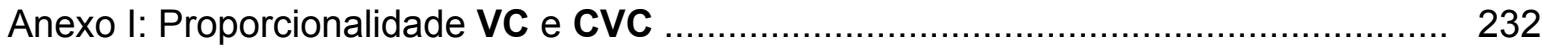




\section{Lista de Abreviaturas}

Todas as palavras em itálico são estrangeiras.

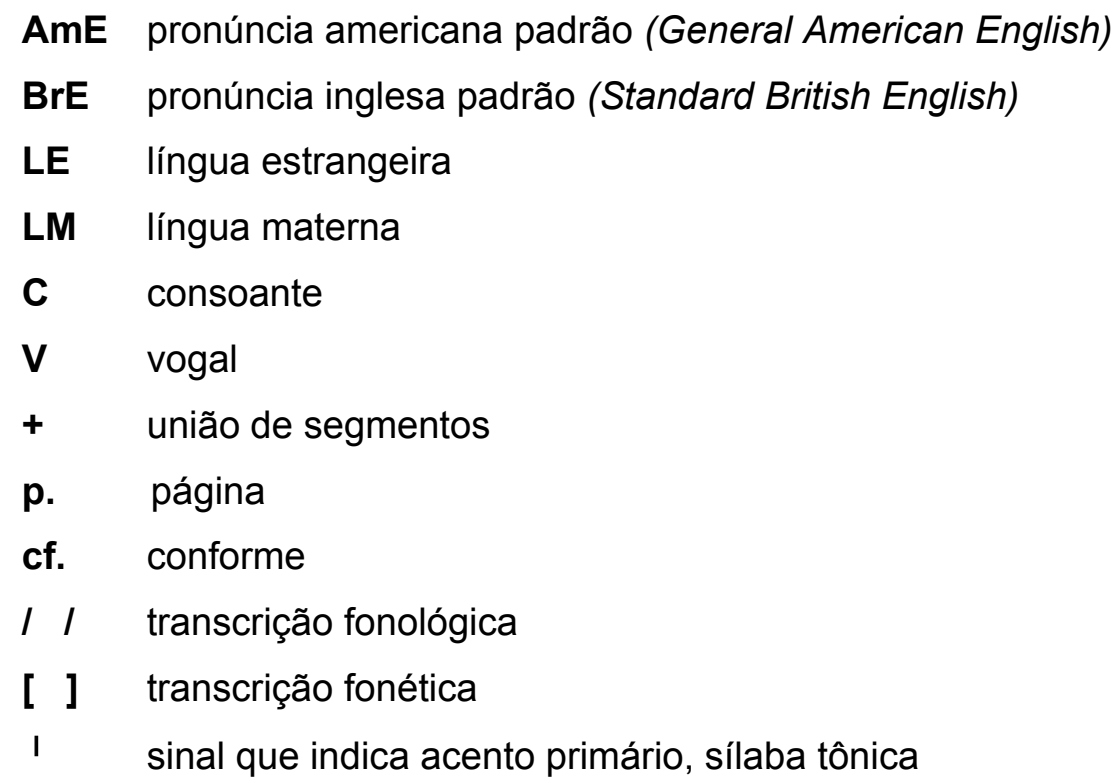

As palavras com fonemas minúsculos erguidos significam:

- sons inseridos opcionalmente ou articulados rapidamente $\rightarrow / \mathrm{w} /, \mathrm{ln}^{\mathrm{n}} / \mathrm{l}^{\mathrm{r}} / \mathrm{l} / \mathrm{j} / \mathrm{l} / \mathrm{\rho}$

- som com aspiração $\rightarrow\left[p^{h}\right]$

- som consonantal silábico $\rightarrow[\underline{m}$ ]

- som intervocálico não acentuado $\rightarrow[\check{r}$ ] 


\section{Lista de Símbolos Fonéticos e Fonológicos}

No quadro contrastivo que se segue teremos: os fonemas portugueses apresentados relativos à pronúncia do português falado na região metropolitana de São Paulo; e, os fonemas ingleses serão apresentados num inventário relativo à pronúncia norteamericana, segundo Jones (1997).

Fonemas consonantais:

\begin{tabular}{|c|c|c|c|c|c|}
\hline \multicolumn{3}{|c|}{ Língua Inglesa } & \multicolumn{3}{|c|}{ Língua Portuguesa } \\
\hline Fonema & Palavra & $\begin{array}{c}\text { Classificação ou } \\
\text { segmento consonantal }\end{array}$ & Fonema & Palavra & $\begin{array}{c}\text { Classificação ou segmento } \\
\text { consonantal }\end{array}$ \\
\hline$/ p /$ & \begin{tabular}{|l|}
$\underline{p}$ in \\
apple \\
tip
\end{tabular} & $\begin{array}{l}\text { Oclusiva bilabial } \\
\text { desvozeada }\end{array}$ & $/ \mathrm{p} /$ & \begin{tabular}{|l|}
$\underline{p} a t a$ \\
tapa \\
-- \\
\end{tabular} & Oclusiva bilabial desvozeada \\
\hline$/ \mathrm{b} /$ & \begin{tabular}{|l}
$\underline{b} i n$ \\
$a \underline{b} \underline{b}$ ove \\
pub
\end{tabular} & Oclusiva bilabial vozeada & $/ \mathrm{b} /$ & \begin{tabular}{|l|}
$\underline{b} a t a$ \\
tabba $a$ \\
--
\end{tabular} & Oclusiva bilabial vozeada \\
\hline$/ \mathrm{t} /$ & $\begin{array}{l}\underline{t i n} \\
\text { return } \\
\text { bit }\end{array}$ & $\begin{array}{l}\text { Oclusiva alveolar } \\
\text { desvozeada }\end{array}$ & $/ \mathrm{t} /$ & \begin{tabular}{|l|}
$\underline{\text { tapa }}$ \\
pata \\
--
\end{tabular} & $\begin{array}{l}\text { Oclusiva alveolar ou dental } \\
\text { desvozeada }\end{array}$ \\
\hline$/ \mathrm{d} /$ & $\begin{array}{l}\text { dear } \\
\text { added } \\
\text { fade }\end{array}$ & Oclusiva alveolar vozeada & $/ \mathrm{d} /$ & $\begin{array}{l}\text { dar } \\
\text { radar } \\
---\end{array}$ & $\begin{array}{l}\text { Oclusiva alveolar ou dental } \\
\text { vozeada }\end{array}$ \\
\hline$/ \mathrm{k} /$ & \begin{tabular}{|l|}
$\underline{c} a t$ \\
occupied \\
pack
\end{tabular} & Oclusiva velar desvozeada & $/ \mathrm{k} /$ & \begin{tabular}{|l|} 
capa \\
paca $a$ \\
-- \\
\end{tabular} & Oclusiva velar desvozeada \\
\hline$/ \mathrm{g} /$ & $\begin{array}{l}\text { gap } \\
\text { baggage } \\
\text { bag }\end{array}$ & Oclusiva velar vozeada & $/ \mathrm{g} /$ & \begin{tabular}{|l|} 
gata \\
pega \\
--- \\
\end{tabular} & Oclusiva velar vozeada \\
\hline$/ \mathrm{f} /$ & $\begin{array}{l}\text { fate } \\
\text { coffee } \\
\text { wife }\end{array}$ & $\begin{array}{l}\text { Fricativa labiodental } \\
\text { desvozeada }\end{array}$ & $/ \mathrm{f} /$ & \begin{tabular}{|l|} 
fato \\
caféé \\
---
\end{tabular} & $\begin{array}{l}\text { Fricativa labiodental } \\
\text { desvozeada }\end{array}$ \\
\hline$/ \mathrm{v} /$ & \begin{tabular}{|l|}
$\underline{v} a n$ \\
divine \\
give \\
\end{tabular} & $\begin{array}{l}\text { Fricativa labiodental } \\
\text { vozeada }\end{array}$ & $/ \mathrm{v} /$ & \begin{tabular}{|l}
$\underline{\text { vir }}$ \\
aviso \\
-- \\
\end{tabular} & Fricativa labiodental vozeada \\
\hline$/ \theta /$ & $\begin{array}{l}\text { thin } \\
\text { other } \\
\text { faith }\end{array}$ & $\begin{array}{l}\text { Fricativa linguodental } \\
\text { desvozeada }\end{array}$ & & --- & \\
\hline / б / & $\begin{array}{l}\text { that } \\
\text { feather } \\
\text { bathe }\end{array}$ & $\begin{array}{l}\text { Fricativa linguodental } \\
\text { vozeada }\end{array}$ & & \begin{tabular}{|c|}
-- \\
\end{tabular} & \\
\hline$/ \mathrm{s} /$ & \begin{tabular}{|l} 
sin \\
beśide \\
gás \\
\end{tabular} & $\begin{array}{l}\text { Fricativa alveolar } \\
\text { desvozeada }\end{array}$ & $/ \mathrm{s} /$ & $\begin{array}{l}\underline{s} a c o \\
\text { caća } \\
\text { nós } \\
\end{array}$ & $\begin{array}{l}\text { Fricativa alveolar } \\
\text { desvozeada }\end{array}$ \\
\hline$|z|$ & $\begin{array}{l}\frac{\underline{z i p}}{\text { desert }} \\
\frac{\text { verb) }}{\text { these }} \\
\text { these }\end{array}$ & Fricativa alveolar vozeada & $/ z /$ & \begin{tabular}{|l} 
zica \\
casa \\
---
\end{tabular} & Fricativa alveolar vozeada \\
\hline
\end{tabular}

Continua... 


\begin{tabular}{|c|c|c|c|c|c|}
\hline \multicolumn{3}{|c|}{ Língua Inglesa } & \multicolumn{3}{|c|}{ Língua Portuguesa } \\
\hline $\begin{array}{c}\text { Fone- } \\
\text { ma }\end{array}$ & Palavra & $\begin{array}{l}\text { Classificação ou } \\
\text { segmento consonantal }\end{array}$ & $\begin{array}{c}\text { Fone- } \\
\text { ma }\end{array}$ & Palavra & $\begin{array}{c}\text { Classificação ou segmento } \\
\text { consonantal }\end{array}$ \\
\hline $15 /$ & $\begin{array}{l}\text { ship } \\
\text { fashion } \\
\text { fish }\end{array}$ & $\begin{array}{l}\text { Fricativa alveolopalatal } \\
\text { desvozeada }\end{array}$ & $1 / 1$ & \begin{tabular}{|l|}
$\underline{x}$ ale \\
caixa $a$ \\
--
\end{tabular} & $\begin{array}{l}\text { Fricativa alveolopalatal } \\
\text { desvozeada }\end{array}$ \\
\hline$/ 3 /$ & $\begin{array}{l}-- \\
\text { pleasure } \\
\text { rouge }\end{array}$ & $\begin{array}{l}\text { Fricativa alveolopalatal } \\
\text { vozeada }\end{array}$ & $/ 3 /$ & \begin{tabular}{|l} 
jóia \\
agito \\
-- \\
\end{tabular} & $\begin{array}{l}\text { Fricativa alveolopalatal } \\
\text { vozeada }\end{array}$ \\
\hline$/ \mathrm{h} /$ & $\begin{array}{l}\text { home } \\
\text { ahead } \\
--\end{array}$ & Fricativa glotal desvozeada & & --- & \\
\hline$/ \mathrm{t} \int /$ & \begin{tabular}{|l|} 
cheap \\
question \\
fetch \\
\end{tabular} & $\begin{array}{l}\text { Africada alveolopalatal } \\
\text { desvozeada }\end{array}$ & {$\left[\mathrm{t} \int\right]$} & \begin{tabular}{|l}
$\underline{\text { tia }}$ \\
atirar \\
--- \\
\end{tabular} & $\begin{array}{l}\text { Africada alveolopalatal } \\
\text { desvozeada }\end{array}$ \\
\hline$/ \mathrm{d} 3 /$ & $\begin{array}{l}\text { jam } \\
\text { suggest } \\
\text { edge }\end{array}$ & $\begin{array}{l}\text { Africada alveolopalatal } \\
\text { vozeada }\end{array}$ & {$\left[d_{3}\right]$} & \begin{tabular}{|l} 
dia \\
ridícula \\
---
\end{tabular} & $\begin{array}{l}\text { Africada alveolopalatal } \\
\text { vozeada }\end{array}$ \\
\hline$/ \mathrm{m} /$ & $\begin{array}{l}\text { map } \\
\text { coming } \\
\text { come }\end{array}$ & Nasal bilabial vozeada & $/ \mathrm{m} /$ & \begin{tabular}{|l} 
mapa \\
cama \\
---
\end{tabular} & Nasal bilabial vozeada \\
\hline $\mathrm{ln} /$ & \begin{tabular}{|l|}
$\underline{n} e t$ \\
connect \\
cone \\
\end{tabular} & Nasal alveolar vozeada & $/ \mathrm{n} /$ & \begin{tabular}{|l|} 
nata \\
cana \\
--- \\
\end{tabular} & $\begin{array}{l}\text { Nasal alveolar ou dental } \\
\text { vozeada }\end{array}$ \\
\hline $\ln /$ & $\begin{array}{l}-- \\
\text { banker } \\
\text { singing }\end{array}$ & Nasal velar vozeada & & --- & \\
\hline & --- & & $|n|$ & $\begin{array}{l}\text { nhoque } \\
\text { manha } \\
---\end{array}$ & Nasal palatal vozeada \\
\hline & --- & & $/ \kappa /$ & $\begin{array}{l}\text { Ihama } \\
\text { malha } \\
---\end{array}$ & Lateral palatal vozeada \\
\hline$/ 1 /$ & \begin{tabular}{|l|} 
late \\
collect \\
call
\end{tabular} & Lateral alveolar vozeada & $/ 1 /$ & \begin{tabular}{|l} 
leite \\
calar \\
--- \\
\end{tabular} & $\begin{array}{l}\text { Lateral alveolar ou dental } \\
\text { vozeada }\end{array}$ \\
\hline$[+]$ & $\begin{array}{l}-- \\
--- \\
\text { call } \\
\end{array}$ & $\begin{array}{l}\text { Lateral alveolar vozeada } \\
\text { velarizada }\end{array}$ & & --- & \\
\hline$/ \mathrm{r} /$ & $\begin{array}{l}\text { rate } \\
\text { carried } \\
\text { care } \\
\end{array}$ & Retroflexa lateral vozeada & $/ \mathrm{r} /$ & \begin{tabular}{|l} 
reta \\
carro \\
-- \\
\end{tabular} & $\begin{array}{l}\text { Vibrante múltipla alveolar } \\
\text { vozeada }\end{array}$ \\
\hline$[\mathrm{t}]$ & \begin{tabular}{|l}
--- \\
letter \\
--- \\
\end{tabular} & Tepe alveolar vozeado & $/ \mathrm{r} /$ & \begin{tabular}{|l}
-- \\
caro \\
--- \\
\end{tabular} & Tepe alveolar vozeado \\
\hline$/ \mathrm{w} /$ & $\begin{array}{l}\text { water } \\
\text { awake } \\
---\end{array}$ & Semivogal bilabial vozeada & $/ w /$ & \begin{tabular}{|l}
-- \\
ágúa \\
mau
\end{tabular} & Semivogal bilabial vozeada \\
\hline$/ \mathrm{j} /$ & \begin{tabular}{|l|} 
yes \\
onion \\
-- \\
\end{tabular} & Semivogal palatal vozeada & $/ \mathrm{j} /$ & $\begin{array}{l}-- \\
\text { doido } \\
\text { sai }\end{array}$ & Semivogal palatal vozeada \\
\hline
\end{tabular}


a) Fonemas vocálicos:

Os fonemas vocálicos elencados abaixo são apenas os orais, apresentados por Jones (1997). Optamos por não apresentar os fonemas vocálicos nasais por esta ser uma característica apenas do sistema fonológico do Português, não havendo como contrastar com os fonemas ingleses.

\begin{tabular}{|c|c|c|c|c|c|}
\hline \multicolumn{3}{|c|}{ Língua Inglesa } & \multicolumn{3}{|c|}{ Língua Portuguesa } \\
\hline Fonema & Palavra & Classificação & Fonema & Palavra & Classificação \\
\hline$/ \mathrm{i}: /$ & tea & $\begin{array}{l}\text { Anterior longa não- } \\
\text { arredondada alta }\end{array}$ & & --- & \\
\hline$/ \mathrm{I} /$ & pin & $\begin{array}{l}\text { Anterior breve não- } \\
\text { arredondada alta }\end{array}$ & $/ \mathrm{I} /$ & pino & $\begin{array}{l}\text { Anterior não-arredondada } \\
\text { alta }\end{array}$ \\
\hline $\mid v /$ & look & $\begin{array}{l}\text { Posterior breve } \\
\text { arredondada alta }\end{array}$ & $\mid v /$ & súco & $\begin{array}{l}\text { Posterior arredondada } \\
\text { alta }\end{array}$ \\
\hline / u: / & blue & $\begin{array}{l}\text { Posterior longa } \\
\text { arredondada alta }\end{array}$ & & --- & \\
\hline$/$ e / or / $/ \varepsilon /$ & be $d$ & $\begin{array}{l}\text { Anterior breve não- } \\
\text { arredondada média-alta }\end{array}$ & $/ \varepsilon /$ & belo & $\begin{array}{l}\text { Anterior aberta não- } \\
\text { arredondada média-baixa }\end{array}$ \\
\hline & --- & & $/ \mathrm{e} /$ & pela & $\begin{array}{l}\text { Anterior fechada não- } \\
\text { arredondada média-alta }\end{array}$ \\
\hline /æ / & back & $\begin{array}{l}\text { Anterior breve não- } \\
\text { arredondada baixa }\end{array}$ & & --- & \\
\hline$/ \wedge /$ & cult & $\begin{array}{l}\text { Central breve baixa } \\
\text { (vogal tônica) }\end{array}$ & / a / & bala & Central aberta baixa \\
\hline$/ \theta$ / & $\underline{a g o}$ & $\begin{array}{l}\text { Central breve media } \\
\text { (vogal átona) }\end{array}$ & & --- & \\
\hline / or / & sailor & $\begin{array}{l}\text { Central breve média } \\
\text { ("r-coloured schuwa") }\end{array}$ & & \begin{tabular}{|l|}
-- \\
\end{tabular} & \\
\hline / 3:(r)/ & work & Central longa média & & --- & \\
\hline / a: / & heart & $\begin{array}{l}\text { Posterior longa aberta } \\
\text { baixa }\end{array}$ & & --- & \\
\hline$/ \mathrm{b} /$ & pot & $\begin{array}{l}\text { Posterior breve } \\
\text { arredondada baixa }\end{array}$ & & --- & \\
\hline & --- & & $/ 0 /$ & copo & $\begin{array}{l}\text { Posterior aberta } \\
\text { arredondada média-baixa }\end{array}$ \\
\hline / 0: / & more & $\begin{array}{l}\text { Posterior longa } \\
\text { arredondada média }\end{array}$ & & --- & \\
\hline & --- & & 101 & povo & $\begin{array}{l}\text { Posterior fechada } \\
\text { arredondada média-alta }\end{array}$ \\
\hline
\end{tabular}


b) Os ditongos:

\begin{tabular}{|c|c|c|c|}
\hline \multicolumn{2}{|c|}{ Língua Inglesa } & \multicolumn{2}{|c|}{ Língua Portuguesa } \\
\hline Fonema & Palavra & Fonema & Palavra \\
\hline \multirow[t]{2}{*}{ / ey / } & say & / ex / & sei \\
\hline & --- & / عI / & papéis \\
\hline / ay / & buy & / ar / & cai \\
\hline \multirow[t]{2}{*}{ / oy / } & boy & / ग1 / & dói \\
\hline & --- & / or I & boi \\
\hline / eə(r) / & there & & --- \\
\hline \multirow[t]{2}{*}{$/ \mathrm{I} \theta(\mathrm{r}) /$} & here & / тә / / та / & séria \\
\hline & --- & / ie / / i / & cárie \\
\hline \multirow[t]{4}{*}{ /Uə(r)/ } & poor & / və / / va / & rua \\
\hline & |--- & / UI / & fui \\
\hline & --- & / vo / & árduo \\
\hline & --- & / iv / / io / & partiu \\
\hline \multirow[t]{3}{*}{ / av / } & now & / au / & nau \\
\hline & |--- & / eu / & meu \\
\hline & --- & / \&u / & chapéu \\
\hline / ou / & $s \underline{O}$ & / ou / & sou \\
\hline
\end{tabular}




\section{SUMÁRIO}

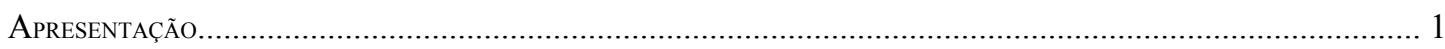

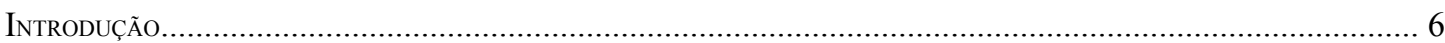

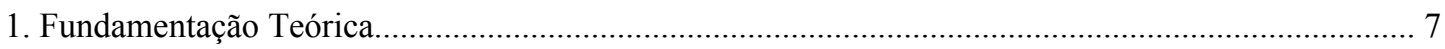

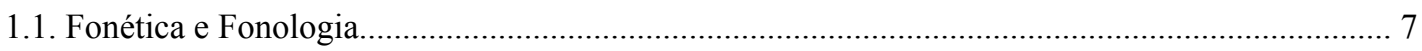

1.2. Aquisição Fonológica de Segunda Língua................................................................................ 10

1.2.1. A Relação entre Percepção e Produção da Fala....................................................................... 18

1.2.2. Relação entre a Linguagem Oral e Escrita......................................................................... 23

1.2.3. Aspectos Gerais sobre Ensino-Aprendizagem................................................................ 26

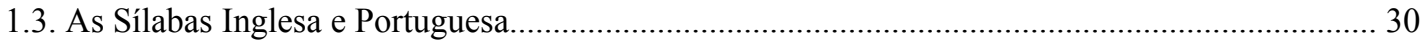

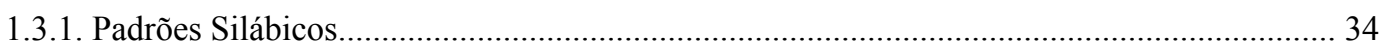

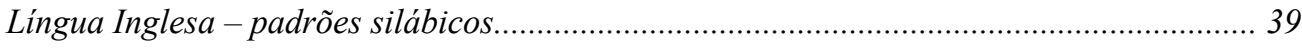

Lingua Portuguesa - padrões silábicos........................................................................ 48

Contraste dos Padrões Silábicos do Inglês e do Português................................................ 52

1.3.2. Particularidades Fonológicas da Sílaba Inglesa Final......................................................... 53

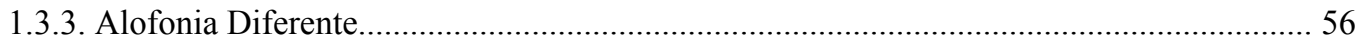

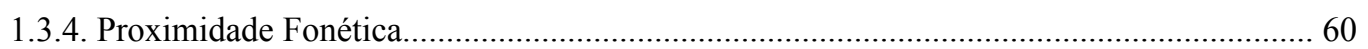

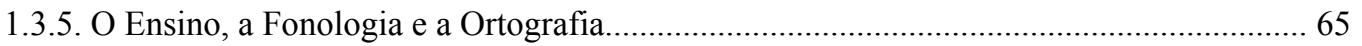

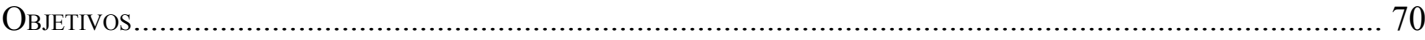

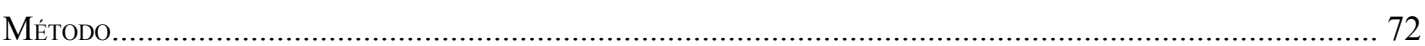

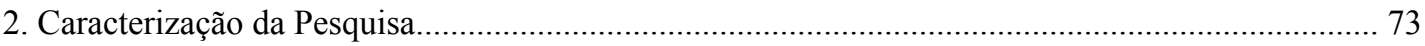

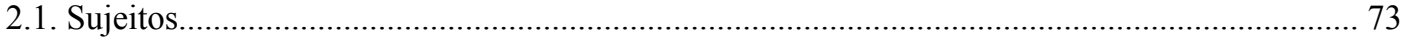

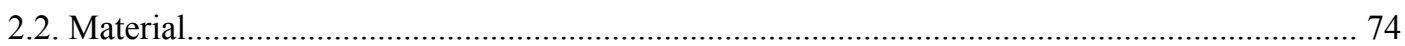

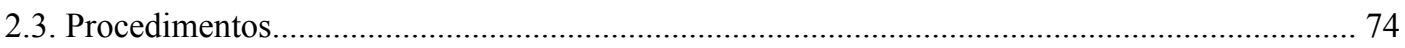

2.3.1. Seleção dos sujeitos.................................................................................................... 74

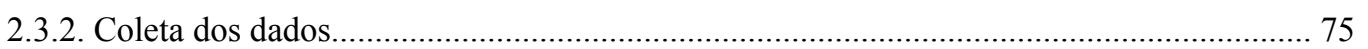

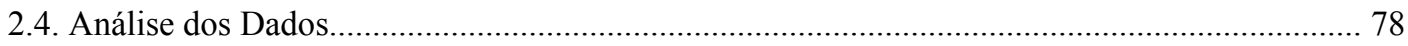

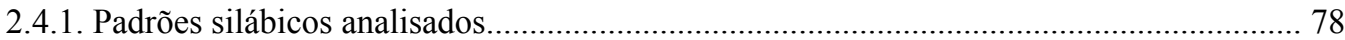

2.4.2. A relação dos padrões silábicos (CVC e VC) com o vocábulo seguinte............................ 82

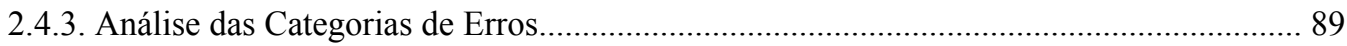

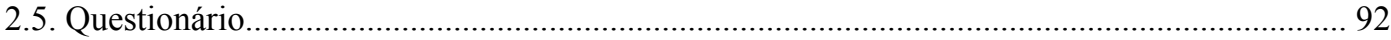

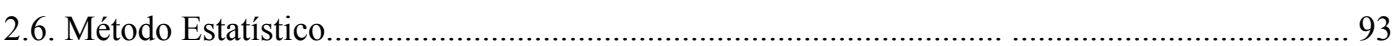




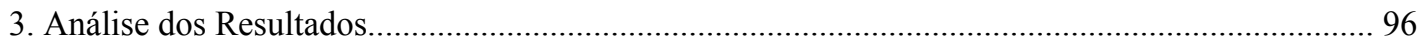

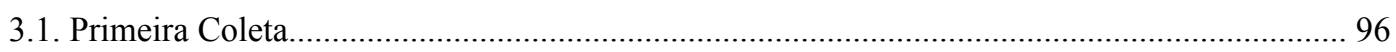

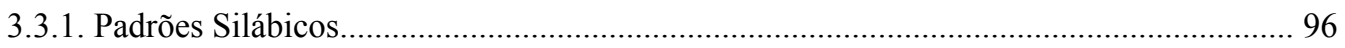

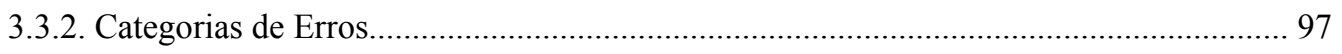

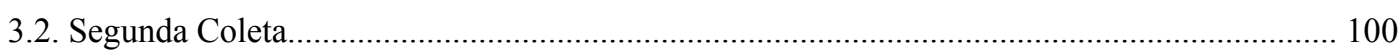

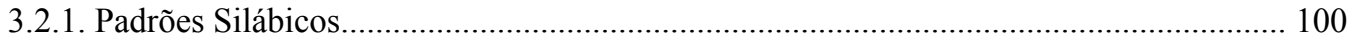

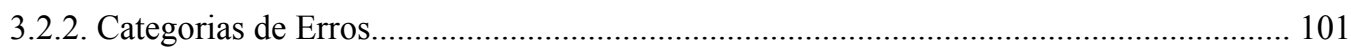

3.3. Comparação entre as Duas Coletas..................................................................................... 102

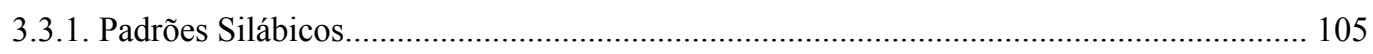

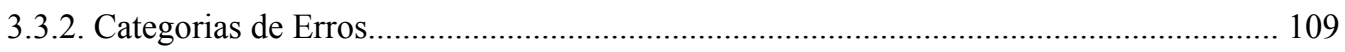

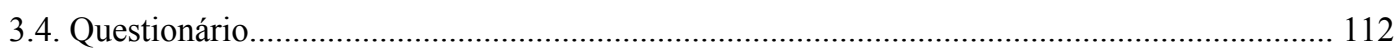

3.5. Relação entre Itens do Questionário e Categorias de Erros.................................................. 119

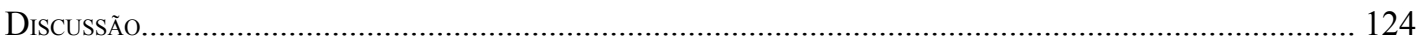

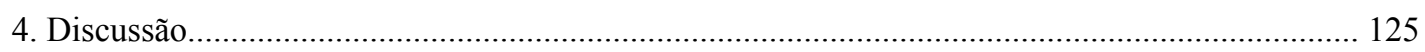

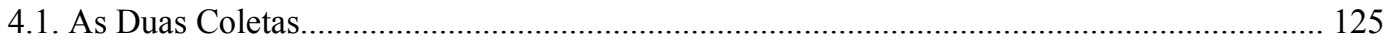

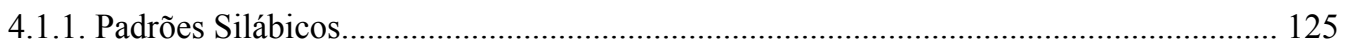

Os Padrões Silábicos Finais e Sua Relação com o Vocábulo Seguinte....................... 126

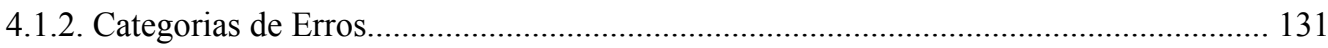

4.2. Relação entre Questionário e Categorias de Erros............................................................. 135

4.3. Implicações Pedagógicas................................................................................................... 137

4.3.1. A interferência da língua materna....................................................................... 137

4.3.2. Importância do contraste das línguas envolvidas................................................... 146

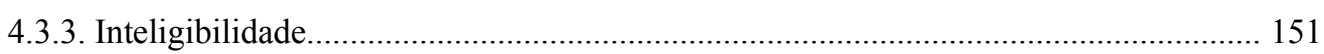

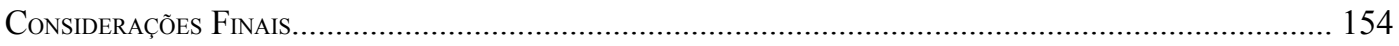

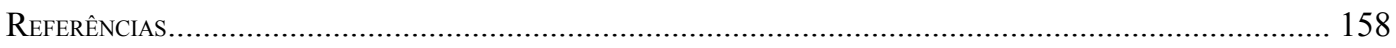

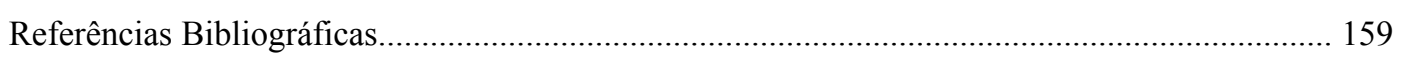

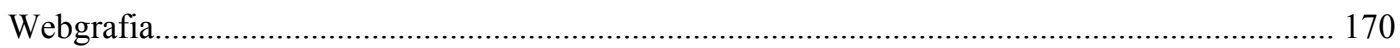

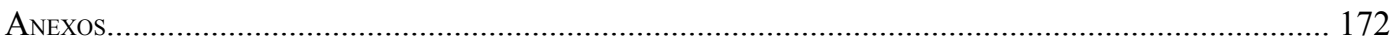



Apresentação 
A comunicação entre as pessoas, os povos, sempre foi objeto de estudo de lingüistas. As pesquisas são inúmeras, pois cabe ao lingüista a tarefa de explicar os mecanismos da linguagem e o uso das línguas.

Nossa pesquisa está diretamente ligada à nossa própria história acadêmico-profissional dedicada há mais de 15 anos ao ensino de inglês para universitários brasileiros, do curso de Letras e de Tradutor. Acreditamos que esta seja uma justificativa plausível para a escolha do tema relacionado ao ensinoaprendizagem do inglês como língua estrangeira, uma vez que nas aulas de língua inglesa, constantemente nos deparamos com situações em que a pronúncia ${ }^{1}$ dos estudantes é deficiente.

Então, especificamente para esta pesquisa, escolhemos como foco principal analisar os fonemas consonantais ingleses em final de vocábulo e seus respectivos padrões silábicos, que serão identificados a partir do nosso corpus, de um grupo de 45 falantes brasileiros, estudantes do curso de Tradutor de uma universidade privada da cidade de São Paulo. Num primeiro momento temos como objetivo realizar uma descrição fonético-fonológica dos fonemas consonantais ingleses em final de vocábulo e seus respectivos padrões silábicos, segundo as categorias de erros que serão identificados a partir do nosso corpus, que foi coletado na gravação de um texto sem treino para a $1^{\text {a }}$ coleta e após treino para compor a $2^{a}$ coleta. Em seguida faremos uma descrição, uma comparação e uma análise dessas dificuldades de produção dos fonemas. A descrição dos dados coletados será apresentada do ponto de vista lingüístico.

\footnotetext{
${ }^{1}$ O termo 'pronúncia' deve ser entendido daqui a diante como articulação ou produção dos fonemas de uma língua.
} 
A metodologia utilizada em nossa amostra partirá basicamente da análise contrastiva dos padrões silábicos finais dos vocábulos ingleses e portugueses, usados por 45 sujeitos falantes do português, na leitura de um texto padrão gravado em dois momentos distintos. Sem perder de vista as especificidades de nosso corpus, inicialmente, elencaremos a articulação inadequada ${ }^{2}$ de cada sujeito para que depois, possamos analisar, descrever e explicar os "erros" de articulação ligados às semelhanças e às diferenças fonéticas ou fonológicas entre as línguas em questão. Portanto, analisaremos os erros para identificar e explicar as dificuldades dos sujeitos. O questionário preenchido pelos sujeitos da pesquisa servirá para ter uma idéia do que os estudantes pretendiam quando optaram pelo curso de Tradutor e quais eram suas expectativas quanto à aquisição fonético-fonológica.

Em função de nosso interesse no ensino da língua estrangeira, abordaremos alguns aspectos relacionados ao assunto, com o intuito de contribuir para a melhor compreensão de questões relacionadas ao processo de ensinoaprendizagem, tais como a motivação do estudante em aprender uma segunda língua, ou até mesmo alguns fatores sociais que podem interferir no momento da leitura oral do texto. As diferenças entre as línguas no que diz respeito às sílabas tônicas e a entonação, não foram incluídas nessa pesquisa.

Sabendo da importância da descrição do inventário fonológico de ambas as línguas e que há diferenças, a serem consideradas dadas as diferentes realizações dos fonemas, apresentaremos na fundamentação teórica autores que tratam de questões de ensino-aprendizagem de uma língua estrangeira, das

\footnotetext{
${ }^{2}$ Para esta pesquisa tanto a expressão "articulação ou produção inadequada" bem como o vocábulo "erro" terá a seguinte definição: uma pronúncia incorreta do falante do português ao falar inglês, de acordo com o dicionário de pronúncia de Jones (1997).
} 
descrições lingüísticas individuais e comparadas. Desta forma, tal fundamentação pode ser considerada Estruturalista, na medida que trataremos da seqüência linear de fonemas nos vocábulos (e entre eles), e conseqüentemente analisaremos como esses elementos se manifestam. Consideraremos ainda, como se comporta um fonema na sílaba tanto quanto na interação entre fonemas que podem ser analisados em categorias de erros.

Não podemos perder de vista que haverá uma explicação para as categorias de erros diretamente relacionada à interferência da língua materna dos sujeitos dessa pesquisa. Assim, podemos afirmar que a influência da língua mãe será fundamental para justificarmos as produções orais dos sujeitos e também a ocorrência das categorias de erros que compuseram essa pesquisa. Nas descrições dos erros teremos a intenção de diferenciar as ocorrências realizadas nas duas coletas, e quais vocábulos os sujeitos irão superar suas dificuldades em articular os fonemas e suas seqüências consonantais finais. Após coletar e transcrever os dados coletados, os padrões silábicos mais recorrentes serão identificados para então, realizarmos análises e discussões combinadas às categorias de erros.

Sabemos de antemão que nem sempre é simples e fácil para o falante do português produzir seqüências consonantais com duas ou mais consoantes, uma vez que esse tipo de contexto fonológico não ocorre com freqüência na língua portuguesa. Desta forma iremos explicar as estratégias utilizadas pelo falante do português brasileiro para a produção dos fonemas consonantais finais 
Ainda merece uma explicação a abordagem contrastiva das línguas em questão que será realizada para a análise dos dados de nossa coleta. Isto quer dizer que justificaremos essas articulações inadequadas dos sujeitos no âmbito tradicional da análise contrastiva, a qual trata da identificação e interpretação das formas inadequadas da articulação dos fonemas finais dos vocábulos ingleses sob o conceito de interferência da língua materna.

Nos ativemos também ao questionário para realizar uma análise sobre as categorias de erros encontrados em nossa amostra e a relação que as questões de 23 a 26 tiveram com as categorias de erros. Sabemos que há outras possibilidades para se analisar os dados a partir do questionário, mas para isso teríamos que ter enfatizado aspectos relacionados tanto ao campo da sociolingüística como ao da psicolingüística. O que achamos pertinente para esse momento foi tratar apenas de aspectos lingüísticos de aquisição de segunda língua.

Os resultados terão tratamento estatístico e tratarão de explicar os dados coletados, baseando-se nas categorias de erros e na relação do vocábulo com o vocábulo seguinte. 
INTRODUÇÃO 


\section{Fundamentação Teórica}

\subsection{Fonética e Fonologia}

Áreas da Lingüística, a Fonética e a Fonologia são ciências autônomas, que embora não sejam independentes (CoserIu, 1979), relacionam-se e procuram formar uma unidade de pesquisa. Esse aspecto faz com que uma dependa da outra para tratar de estudos mais contemporâneos relacionados à linguagem. Ambas têm como objeto de estudo os sons da fala, sob diferentes pontos de vista.

A Fonética é descritiva e preocupa-se com a produção, a percepção e a transmissão da fala como linguagem, "é a ciência do falar concreto" (Coseriu, 1979, p.125). Já a Fonologia é explicativa e interpretativa, busca o valor dos sons, e estuda o código de uma língua.

Conforme Coseriu (1979, p.114) "a fonologia ... não se opõe a fonética ... mas a uma fonética definida em relação à fonologia" (grifos do autor). Isto significa que há um campo no qual as duas disciplinas se tocam e uma colabora com a outra, criando uma relação de interdependência entre elas, o que resulta na impossibilidade de haver uma separação entre ambas.

A Fonética ocupa-se dos sons lingüísticos produzidos pelo falante que são captados pelo ouvinte, ou seja, como os fonemas são articulados, partindo do fenômeno acústico e psicológico que envolve o momento da fala (CÂmara Jr., 1977; Coseriu, 1979; Steinberg, 1985; Callou \& Leite, 1995; et alli). 
Cabe então a Fonética observar os sons da fala sob três diferentes pontos de vista:

a) Fonética Articulatória (Motora): preocupa-se com a maneira como os sons são produzidos, segundo os movimentos do aparelho fonador;

b) Fonética Acústica (Sinal Acústico): preocupa-se com a transmissão dos sons, ou seja, como são propagados através do ar;

c) Fonética Auditiva (Perceptual): estuda a forma com que os sons são percebidos pelos ouvintes.

Assim a Fonética dedica-se à descrição da parte física dos órgãos do aparelho fonador, envolvidos na articulação dos sons pelo falante, que são responsáveis pela produção das distinções sonoras (CÂmARA JR, 1970; Mascherpe, 1970; Roach, 1983; Silveira 1986 e 1988; Cagliari e Cagliari, 2000), ou seja, trata-se da linguagem expressiva que possibilita uma correspondência entre os movimentos articulatórios dos órgãos fonadores para a produção de um fonema e sua descrição e classificação captados pelo ouvinte. Segundo MALMBERG (1974, p. 106), “Há, na realidade, tantas variantes de um som lingüístico quantas são as combinações deste som com outros elementos fonéticos." Esse aspecto pode ser exemplificado com a transcrição fonética, que será sempre caracterizada por colchetes, do vocábulo 'cantas' do português ['kãtas]. Portanto, a Fonética procura descrever pormenorizadamente cada fonema, ou seja, quais deles foram utilizados no momento da fala, verificando se houve, por exemplo, desvozeamento, nasalização, assimilação etc. (CRISTÓfARO-SILVA, 2002). 
A Fonologia volta sua atenção para o ponto de vista funcional e sistemático de como se comporta cada fonema que será descrito por um conjunto de traços distintivos invariáveis, com sua representação fonológica, sempre de uma forma comparativa (Mascherpe, 1970; RoACh,1983; Silveira 1986 e 1988). O conhecimento prévio dos sistemas fonológicos (da língua materna e da língua estrangeira) dá a sensação aos falantes-ouvintes de articular e perceber o fonema como uma unidade significativa e distintiva. Podemos exemplificar com a transcrição fonológica, a qual será sempre caracterizada por barras transversais, do mesmo vocábulo 'cantas' do português / 'kaNtaS /. Podemos exemplificar ainda com a representação fonológica dos pares mínimos da língua portuguesa 'sela' e 'zela', na oposição dos fonemas / s / e / z / (CRIStófARo-SiLVA, 2002).

A partir de material fonético, a Fonologia estuda o lado abstrato dos sons de uma língua, ou seja, estuda os fonemas para descobrir como se definem as unidades sonoras distintivas da língua, preocupando-se com a análise de sua função comunicativa para a compreensão necessária na comunicação humana.

Resumindo, podemos estudar a produção sonora vocal baseando-nos nas características físicas e fisiológicas ou de uma perspectiva fonológica em que os fonemas possam ser observados de acordo com suas combinações e relações que dão sentido aos vocábulos. Para melhor ilustrar os comentários acima, podemos usar o exemplo citado por MASCHERPE (1970) do fonema / t / do inglês: é descrito foneticamente como uma oclusiva alveolar surda, com diferenças no ponto de articulação, se é aspirado [ $\mathrm{t}^{\mathrm{h}}$ ] ou não [ $\mathrm{t}$ ], ou se for 
produzido como uma variação livre [ $\breve{r}$ ] em posição intervocálica não-acentuada. Do ponto de vista fonológico a função comunicativa inteligível da língua é a que prevalecerá, mantendo sempre a transcrição / t / como a única possível. Entretanto, faz parte do estudo de ambas as ciências -Fonética e Fonologia-, nos oferecer a possibilidade de adquirir um entendimento completo do uso dos sons da produção oral das línguas.

\subsection{Aquisição Fonológica de Segunda Língua}

A busca por se desvendar os caminhos pelo qual o aprendizado de uma segunda língua passa, abre um leque de possibilidades desde expandir a comunicação entre as pessoas de diferentes comunidades lingüísticas até o grande interesse dos professores de língua estrangeira em atingir a melhoria do ensino da mesma.

A aquisição da segunda língua é um processo psicológico, pois ocorre no subconsciente humano. Tal tópico despertou o interesse dos pesquisadores, desde a segunda metade do século $X X$, na medida em que o fenômeno da globalização passou a exercer forte pressão para o aprendizado de línguas faladas por grande parte das comunidades dispersas pelo mundo.

KRASHEN (1987) diz que o conceito mais importante em aquisição de uma segunda língua é descobrir como nós a adquirimos e como os professores podem lidar com as dificuldades diárias de ensino em todos os níveis, principalmente se considerarmos as variáveis emocionais que envolvem o aprendizado. Aponta ainda que o primeiro tipo de competência lingüística é 
alcançado por meio de um processo inconsciente que precisa ser efetivo, pois neste estágio, para o aprendiz da língua estrangeira o que interessa é que ele esteja mantendo uma comunicação, sem se preocupar com a aquisição e internalização das regras ou das estruturas fonológicas ou sintáticas.

Há também segundo o mesmo autor KRASHEN (1987), uma outra possibilidade de conquista do aprendizado que pode ser consciente, isto é, aquele em que o aprendiz conhece todas as regras da língua estrangeira e é capaz de falar sobre elas, de descrevê-las.

Ainda sobre aquisição e aprendizagem ${ }^{3}$ da língua estrangeira, KRASHEN (1987) acrescenta que durante a aquisição inconsciente, pode não haver um bom resultado se houver correção do professor ou ouvinte. Por outro lado quando há uma explicação do erro cometido, o aprendizado será consciente, possibilitando ao estudante a chance de alcançar a competência comunicativa.

Entretanto o que interessa para KRASHEN (1987) é de que maneira a língua estrangeira é internalizada pelo estudante. Assim, ele denomina de "The input hypothesis", apresentando como se processa o ato da fala durante o aprendizado. Afirma que primeiramente nos concentramos no significado do assunto que queremos transmitir para depois alcançarmos o nível estrutural do que irá ser dito, ou como iremos dizê-lo.

Ainda sobre esse mesmo tema, nível de internalização da segunda língua, para WIDDowson (1978) se a informação desejada estiver expressa na fala, não importará se alguns vocábulos forem ou não articulados

\footnotetext{
${ }^{3}$ Aquisição e Aprendizagem são processos que não devem ser confundidos. Podem ser tratados juntos se entendermos que a aquisição de uma língua é um processo de ensino considerado psicológico, quando se realiza individualmente e sem professor. Entretanto, aquisição e aprendizagem são processos que unem para tratar de problemas absolutamente didáticos. (SLAMA-CAZACU, 1979.)
} 
corretamente. Nesse sentido podemos retomar a hipótese de KRASHEN (1987) no que diz respeito à comunicação, quando afirma que cada aprendiz atingirá a fala fluente e o conhecimento da língua ao seu tempo.

Ao considerarmos o ato da fala, $\operatorname{LADO}(1957$, p. 15) aponta que no momento da articulação dos vocábulos na sentença, para o aluno "os elementos que forem similares a sua língua nativa serão simples para ele e os que forem diferentes serão difíceis". Isto quer dizer que para cada estudante haverá determinados padrões silábicos da língua estrangeira que serão fáceis de serem adquiridos enquanto outros não. Para JAKOBSON (1969) as diferenças soam difíceis de serem aprendidas, mas fácies de serem percebidas. Esse aspecto mostra que as falsas semelhanças podem apresentar dificuldade até maior durante o aprendizado de uma língua estrangeira. Tudo depende do esforço que o estudante faz para perceber as semelhanças e as diferenças.

Para o falante adulto que aprende a língua estrangeira, notaremos que o nível de dificuldade para produzir os sons da língua-alvo está diretamente ligado à dificuldade de perceber auditivamente os sons diferentes da sua língua materna, muito embora ele não tenha problema articulatório ou mesmo deficiência auditiva.

$\mathrm{Na}$ fala do estudante adulto, por exemplo, conforme KRASHEN (1987) afirma, há uma possibilidade bastante grande desta resultar numa produção de vocábulos que soará estranha para o ouvinte nativo. Segundo SLAMACAZACu (1979) isto ocorre porque o adulto não se submete a imitações como a criança no início do aprendizado da sua língua materna, fato esse que não se 
pode negligenciar, pois o estudante adulto tem sua personalidade, sua maneira de internalizar a segunda língua diferentemente da criança.

Entretanto, para BoWERMAN \& LeVInson (2000) tanto a aquisição da língua materna como a da língua estrangeira, devem ser considerados um tema obscuro, do ponto de vista da internalização ou mesmo da ordem das regras em que aprendemos uma língua. Segundo os autores, não há uma ordem préestabelecida para aquisição da língua. Especificamente para a aquisição da língua materna, os autores afirmam que as crianças aprendem-na a partir de conceitos universais.

GASS \& SELINKER (2001) discutem como o estudante adquire a segunda língua, afirmando que para eles o processo de aprendizagem pode significar uma série de questões relacionadas a uma perspectiva multidisciplinar. Para os autores, ao aprender uma língua estrangeira o estudante utiliza uma variedade de estratégias já adquiridas em diferentes áreas do conhecimento para alcançar a proficiência na língua estrangeira. Dessa forma é difícil dimensionar quais áreas o estudante utilizou ou mesmo como ele o fez, pois esse é um processo mental natural utilizado no momento da comunicação por todos nós, seja para a língua materna ou a língua estrangeira.

No que diz respeito à inteligibilidade da fala, KENWORTHY (1990) e Poedjosoedarmo (2004) analisam quais são os fatores que dificultam e interferem no aprendizado fonológico de uma segunda língua, ou seja, como o desenvolvimento e a mudança na produção oral do estudante se transforma nesse período pelo qual ele internaliza a língua. 
As mesmas autoras citadas acima ${ }^{4}$ afirmam que encontraremos erros de diferentes tipos, tais como: troca de um fonema; omissão de fonemas; acréscimo de fonema(s); troca da sílaba tônica do vocábulo; acento no vocábulo errado da frase; padrão de entonação; e até mesmo, de uma combinação dessas dificuldades. Esses possíveis erros, para os estudantes adultos de uma segunda língua, devem ser superados durante a aprendizagem, uma vez que o estudante poderá treinar a articulação dos vocábulos e sentenças até atingir uma fala mais clara e próxima do falante nativo.

Assim reafirmamos que a aquisição de uma língua estrangeira envolve diferentes tipos de aprendizado. Isto quer dizer que o aluno segue diferentes caminhos para alcançar a língua-alvo (KRASHEN, 1987). Por exemplo, ao aprender uma língua estrangeira, o estudante pode seguir um padrão de desenvolvimento particular de aprendizagem devido ao fato de suas faculdades mentais estarem estruturadas de uma certa forma. Ao receber informações importantes sobre a língua, tais como as regras do novo sistema fonéticofonológico, ele poderá organizá-las e armazená-las em sua memória, para que ao precisar utilizá-las, estejam disponíveis. Porém, não há como saber em que ordem ou de que maneira essas informações serão utilizadas no momento da fala. Pois cada aluno irá utilizar diferentes “caminhos' para qualquer aquisição/ aprendizagem, no seu tempo.

Nesse sentido, as estratégias fonológicas de aprendizado para HARMER (1994) também são consideradas métodos particulares, os quais o aluno utiliza para aprender a língua-alvo. Cita que dentre as estratégias usadas o estudante pode repetir os vocábulos novos em voz alta para memorização

\footnotetext{
${ }^{4}$ Op. cit. Kenworthy (1990) e Poedjosoedarmo (2004).
} 
auditiva, ou mesmo mentalmente, tentando associar um vocábulo novo por meio de contexto lingüístico ou situacional. O autor menciona ainda que a habilidade de se comunicar está ligada ao nível de aprendizado, mas que por outro lado também devem ser considerados outros fatores, por exemplo, qual é o motivo do estudante em alcançar a fluência na segunda língua.

Outro aspecto que devemos levar em consideração, muito embora seja uma característica individual, é o tempo que o estudante demora em aprender. Uns necessitam de mais tempo do que outros para internalizar a fonologia dos vocábulos e sua produção.

Quer essas produções orais do estudante sejam transferências positivas ou negativas ${ }^{5}$ e ocorram de variadas formas, elas não podem ser ignoradas, pois o aluno sempre terá como ponto de partida a língua materna para se comunicar na língua estrangeira, pelo menos no início do aprendizado da língua-alvo.

Para Dalton \& Seidlhorfer (1994, p. 37) o padrão silábico da língua materna filtra os sons da língua-alvo, transformando-os nos de sua própria língua, ou seja, "if the syllable structure of the second language word is not 'legal' in the own language, the sound pattern of the word is changed until it is."

Esse aspecto foi mencionado por SteINBERg (1985, p. 9) no trecho "Quando ouvimos uma língua estrangeira, tendemos a pensar que os sons dessa língua são os mesmos que os da nossa, mas distorcidos de alguma forma.”, bem como também foi discutido por Celce-Murcia \& Goodwin (1991, p. 137) quando afirmam que a fala estranha desenvolvida pelo falante de outra língua ocorre

\footnotetext{
${ }^{5} \mathrm{O}$ termo transferência positiva contraposto aos termos interferência ou transferência negativa é utilizado por Klein (1986) e Steinberg (1985 e 2006) para melhor definir a ocorrência de erros entre as línguas contrastadas, ou seja, a língua nativa e a língua estrangeira.
} 
porque a influência da língua materna na produção dos fonemas da língua estrangeira é mais "sistemática, penetrante e persistente".

Contudo, durante o aprendizado de uma língua estrangeira devemos mencionar que nas aulas de um professor não-nativo, a fala também poderá parecer estranha, uma vez que para este obter uma pronúncia muito próxima do falante nativo será necessário que ele tenha realizado um esforço demasiado a partir de materiais didáticos de pronúncia de ambas as línguas, ou mesmo ter passado um tempo no país da língua em questão. Apenas dessa maneira ele poderá atingir a proficiência comunicativa, a qual compreende principalmente no reconhecimento pelos falantes nativos da inteligibilidade da fala do falante estrangeiro.

Segundo Celce-Murcia \& Goodwin (1991) o fato do professor nãonativo conhecer os fonemas de ambas as línguas envolvidas no processo de ensino e aprendizagem, faz com que possa antecipar os possíveis erros de articulação dos fonemas dos alunos e com isso ajudá-los a superar suas dificuldades em articulá-los.

Abordando o ensino e a aprendizagem da língua estrangeira de uma forma geral, KLEIN (1986) acrescenta no trecho abaixo que:

Transfer has been observed on various linguistic levels mainly in phonology, and in the lexicon, but also in syntax. It is quite rare in morphology. [...] Whenever a learner of a second language tries to comprehend or to produce utterances in that language, he relies on all sorts of knowledge that might help him. [...] It is this interaction of different kinds of knowledge that needs to be considered in order to understand what a learner does, and why he does it. (KLEIN, 1986, p. 27-28) 
As afirmações dos pesquisadores citados acima apenas reforçam o que já foi relatado por outros lingüistas sobre o início do aprendizado de uma língua estrangeira, por exemplo, como LADO (1957) que a transferência nada mais é que uma imitação, uma utilização de fonemas comuns às duas línguas.

[...] o falante de uma língua escutando outra não ouve, na realidade, as unidades fônicas da língua estrangeira - os fonemas. Escuta as de sua própria língua. As diferenças fonêmicas da língua estrangeira passarão sistematicamente desapercebidas por ele se não houver nenhuma diferença fonêmica similar em sua língua materna. (LADO, 1957, p. 27)

O trecho acima nos prova que a interferência nada mais é que a tentativa do aprendiz em reproduzir fonemas desconhecidos ao inventário fonológico da sua língua materna, empregando um fonema com alguma semelhança nos vocábulos da língua-alvo.

Sendo assim o aprendiz da língua inglesa como segunda língua considera sua língua materna para produzir os vocábulos ingleses. No momento da fala há erros de interferência ou transferência negativa da sua língua para a estrangeira. Entretanto, devemos considerar que há também a transferência positiva, na qual o estudante baseia-se em regras a partir do inventário fonológico que ele está habituado. Utiliza-se dos fonemas da língua materna que ele já internalizou, já que esses são similares aos da língua-alvo (LADO, 1957).

É preciso pensar que nem sempre as dificuldades de aquisição fonológica da língua estrangeira são as mesmas para os aprendizes; não há como identificar se existe uma ordem exata de aquisição; nem mesmo um 
aspecto particular que capacite $\mathrm{o}$ aluno a adquirir a língua-alvo durante $\mathrm{o}$ aprendizado, seja este com ou sem instruções formais. A aquisição fonológica de uma segunda língua segue padrões mentais individuais do estudante.

Na verdade, o que se pode afirmar segundo Eluss (1997), é que o processo de aquisição fonológica é gradual, envolvendo uma série de estágios, de passos, para atingir as construções formais de uma estrutura fonológica particular que é usada como regra pelo falante.

\subsubsection{A Relação entre Percepção e Produção da Fala}

Dalton \& Seidlhofer (1994) afirmam que os humanos possuem um filtro mental, que identifica os ruídos dos sons dos vocábulos com sentido, os quais as pessoas podem produzir. Dessa forma, a nossa percepção é influenciada pelo filtro mental que identifica o sistema de sons como um código. Essa percepção acústica será responsável pelo significado da informação entendida pelo ouvinte. Esse aspecto nos remete a entender que o ouvinte terá condições de entender a seqüência de sons, transformando-as em unidades significativas, mesmo porque foi a partir do caos acústico de sua própria língua que o torna capaz de entender uma outra língua.

Nesse sentido, durante o ensino-aprendizagem de uma segunda língua, o filtro mental provavelmente irá atuar também para o reconhecimento dos sons dessa ou de qualquer língua estrangeira. Essa operação mental realizada pelo ouvinte faz com ele possa identificar os sons semelhantes dos sons diferentes de sua língua. Portanto, uma língua pode servir de instrumento de 
comunicação devido ao fato de estabelecer uma correspondência entre o significado e pronúncia dos vocábulos.

Assim, a partir das citações que acabamos de realizar, entendemos que no geral as pessoas têm capacidade de audição para ouvir e distinguir os sons individualmente em qualquer tipo de contexto.

O mesmo ocorre com relação à produção dos sons. Devemos ser capazes de produzir qualquer tipo de segmento individualmente, ou de forma combinada, ou ainda em seqüência. Assim, durante a fala ou a leitura oral de um texto, as pessoas devem ser capazes de perceber e produzir o nosso sistema de escrita alfabética ortográfica, na qual cada símbolo representa uma consoante e

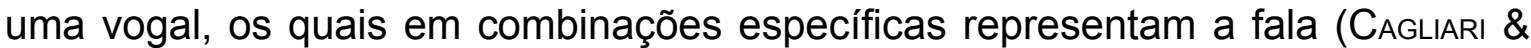
Calgiari, 2000).

Destacamos que para falar e nos comunicar, usamos nosso corpo. A produção da fala envolve vários órgãos que têm funções primárias como a respiração e a deglutição. Ao mesmo tempo vários movimentos que realizamos com o corpo (gestos, expressões faciais) também são importantes para que o ouvinte possa entender a nossa mensagem.

Ao nos tornarmos falantes competentes, a fala se concretiza por meio dos sons para manifestar uma combinação das idéias que representa a linguagem (DALton \& SEIDLHOFER, 1994).

Na fala comunicativa na língua materna, por exemplo, podemos ter um período de silêncio característico, isto é, aquela parada de segundos na 
qual estamos pensando sobre o que vamos dizer a seguir e como vamos dizê-lo (Almeida Filho, 1993; Krashen, 1987; Roseberry-McKibbin \& Brice ${ }^{6}$ ).

O mesmo acontece com o aprendiz da segunda língua, ele também segue esse padrão, pois para alcançar a competência lingüística tal como um falante nativo ele também pára para pensar antes de falar, observa atentamente como as sentenças são construídas, como os vocábulos são produzidos, quando ele está ouvindo ou mesmo lendo.

O exercício desenvolvido para ouvir e entender a língua estrangeira induzirá o estudante a se arriscar e se comunicar (Poedjosoedarmo, 2004). Essa atitude de ouvir e entender a língua demonstra que o falante reflete para se preparar posteriormente para sua produção oral, muito embora ainda faça uso de estruturas fonológicas pré-estabelecidas para determinadas combinações de fonemas (Lado, 1957; Roach, 1983; Odlin, 1989; Schumaker, White \& Zanettini, 2002; CRISTÓFARO-SILVA, 2003).

Assim se a aquisição fonológica da língua estrangeira traz características da língua materna, é possível identificar o "sotaque estrangeiro" do falante não-nativo em qualquer diálogo ${ }^{7}$.

Por isso qualquer vocábulo da língua estrangeira que for produzido com os fonemas da língua materna pode acarretar alterações na inteligibilidade do ouvinte (O'ConNOR, 1980). Nesse caso, o sotaque incomum e a produção de vocábulos inexistentes na língua-alvo podem acarretar num ato

\footnotetext{
${ }^{6}$ Referência retirada da Web: http://www.asha.org/public/speech/development/easl.htm

${ }^{7}$ Devemos ressaltar que o vocábulo 'sotaque' é utilizado em nossa pesquisa com o sentido de falar típico de um povo, de um grupo social. Aliás, isso quer dizer que naturalmente pensamos que os fonemas utilizados pelo aprendiz da língua estrangeira para a produção dos vocábulos são os mesmos que os da nossa línguamãe, porém com algumas diferenças.
} 
comunicativo não compreendido, ou não reconhecido sócio-culturalmente pelo falante na língua que ele deseja falar, o que pode resultar numa barreira lingüística entre o falante e o ouvinte.

Ao abordar esse mesmo aspecto, RIGGEnBACH \& LAZARATON (1991) afirmam que a competência lingüística ou comunicativa não se baseia apenas no aprendizado da gramática da língua-alvo. Essa também está aliada tanto ao conhecimento, como a correta utilização das regras socioculturais préestabelecidas às regras discursivas.

LADO (1957) aborda ainda que para o falante adulto perfeitamente capaz de articular todos os fonemas de sua língua materna, nem sempre há a mesma desenvoltura quando aprende uma língua estrangeira. Quando isso ocorre o falante poderá articular a seqüência de fonemas na sílaba dos vocábulos de duas maneiras: ou substituindo o fonema que deveria ser produzido por um outro de sua própria língua, ou articulando-o inadequadamente.

Duas situações podem ser exemplificadas:

a) Para mantermos um diálogo em uma língua estrangeira com alguém, interagimos com o outro falante e ao mesmo tempo expressarmos todo o conhecimento prévio e ilimitado já apreendido (O'ConnoR, 1980; Roach, 1983; Poedjosoedarmo, 2004).

b) No caso do diálogo ser entre um falante nativo e outro não-nativo, o falante nativo perceberá imediatamente quais são os vocábulos articulados de maneira incorreta ou estranha. Essa situação hipotética, mas que pode ser real, resultará na comprovação de que o falante não- 
nativo não domina o sistema fonológico da língua-alvo, prejudicando assim a comunicação (LAdo, 1957; Harmer, 1994; PoedjosoedArmo, 2004; SсHÜTZ, 2004a).

Tanto Cristófaro-Silva (2002), Jenkins (2005), como Schumaker, White \& ZanetTinı (2002) e Schütz $(2004 a, 2005)$ afirmam que é com o contato constante e o aperfeiçoamento da fala da segunda língua que começamos a perceber e a identificar as reais diferenças de produção dos fonemas das línguas, ou seja, o conjunto de fonemas da língua materna pode ser semelhante a uma série de fonemas da língua-alvo, mas nunca serão fonemas idênticos.

Então, se o falante não-nativo tiver a habilidade auditiva já apurada para perceber as semelhanças e diferenças dos fonemas, essa habilidade irá facilitar as novas estruturas fonológicas. Com o tempo será capaz até de identificar o sotaque estranho ou mesmo os erros cometidos por outro falante.

Enfim, a partir dos estudos já realizados por grandes pesquisadores, consideramos que a tentativa de construir um modelo teórico de como a língua estrangeira é adquirida pelo aprendiz, é um fenômeno complexo que envolve muitos caminhos. Mesmo assim, devemos supor que se houver motivação suficiente por parte do estudante em alcançar um nível de produção dos fonemas da língua estrangeira próxima a do falante nativo, ele terá que investir em tempo e esforço para a melhorar sua pronúncia (CELCE-Murcia \& GoodWin, 1991; Rubin \& Thompson, 2001). 


\subsubsection{Relação entre a Linguagem Oral e Escrita}

Nos estudos lingüísticos a análise contrastiva busca provar que cada língua possui seu próprio sistema sonoro, bem como uma representação gráfica do código escrito.

Devemos enfatizar que na língua inglesa a correspondência 'fonema - grafema' não é transparente, essas manifestações não são idênticas. Ou seja, como afirma O'CoNNOR (1980), embora a fala e a escrita sejam correlatas, a segunda terminantemente não representa a primeira. Nesse mesmo sentido, Poedjosoedarmo (2004) também afirma no trecho abaixo que a escrita da língua inglesa é opaca, ou seja, não tem transparência:

[...] a ortografia da língua inglesa é, obviamente, bastante inconsistente, e facilmente citaríamos pares de palavras transformadas pelos alunos em homônimas homófonas (que se escrevem diferente, apesar de terem a mesma pronúncia): 'days / daze'; 'bear / bare'; 'rays / raise'; 'fare / fair' [...] (Poedjosoedarmo, 2004, p. 9)

Contrariamente ao que ocorre na escrita da língua portuguesa, que não é tão diferente, pois é menos opaca, na maioria das vezes a letra coincide com o fonema. Por isso o aprendizado da escrita dos vocábulos ingleses por falantes do português do Brasil, muitas vezes é um fator de interferência para os estudantes. Para justificar essa interferência durante a aquisição da língua estrangeira KENWORTHY (1990) explica sobre a opacidade da língua inglesa que: 
The English spelling is rich in both regularities and irregularities which present problems to non-native learners [...]. But through a mixture of direct instruction and their own use of the powerful tool of interference, learners can become efficient users of the system. [...] Since English is an alphabetic system, this means basically sorting out which letter correspond to which sound. (KENWORTHY, 1990, p. 9798)

Freqüentemente no início do aprendizado do inglês como língua estrangeira, podemos observar que o aluno apresenta uma tendência em seguir as estratégias fonológicas de sua língua materna, mesmo quando já são quase fluentes na segunda língua.

KenWorthy (1990) entende que para a leitura oral de um texto da língua-alvo, foco dessa pesquisa, o leitor ou o estudante irá usar o que ele já conhece em termos de padrões silábicos do vocábulo da sua língua materna para articular a língua estrangeira. Contudo, como as seqüências de fonemas desses padrões das línguas se combinam de diferentes maneiras, o leitor precisará atingir um nível de conhecimento mais profundo em ambas as línguas sobre esses aspectos de modo que possa se comunicar com maior segurança na língua-alvo. Dessa forma conseguirá, ao longo de seu aprendizado, atingir uma articulação correta.

Podemos exemplificar a opacidade da língua com as letras que não são articuladas em um determinado grupo de vocábulos ingleses, tais como a regra na qual a letra 'k' no vocábulo knowledge, ou o ' $\mathrm{g}$ ' em gnostic, ou o 'm' em mnemonic, ou ainda, o 'p' em pneumonia (exemplos de KenWORTHY, 1990). Devemos ressaltar que em todos esses vocábulos as letras não articuladas precedem a letra 'n'. 
Assim, o leitor sempre terá de se lembrar da regra da língua-alvo antes de ler o texto escrito em voz alta. Ele terá que prestar maior atenção a sua leitura oral se em sua língua materna a ortografia, em sua grande maioria, tiver relação direta com a produção dos fonemas, ou seja, sempre que sua língua materna for mais transparente (CRISTÓFARO-SILVA, 2002).

Tanto os aspectos relacionados às dificuldades de percepção auditiva do som da língua-alvo ou à produção deste com transferência de um fonema da língua materna pode ocorrer por influência da leitura do vocábulo escrito. Resumindo, o estudante não reconhece auditivamente os fonemas que não fazem parte do inventário fonológico da sua língua materna e, por conseguinte os reproduz de forma estranha para o ouvinte nativo. Além disso, as combinações dos fonemas são próprias de cada língua, e há diferenças na transparência da relação 'fonema - grafema'.

\subsubsection{Aspectos Gerais sobre Ensino-Aprendizagem}

Descrever e explicar os aspectos universais da aquisição da segunda língua reforça a premissa de que as diferentes características individuais e o fator social do contexto de aprendizado geram várias dimensões de sucesso. A performance lingüística está diretamente ligada não somente ao conhecimento gramatical já adquirido pelo estudante, mas também à personalidade de cada um em se expor ao se comunicar. KRASHEN (1987) afirma que se há motivação, espontaneidade e autoconfiança, há uma grande probabilidade de sucesso durante o processo de aquisição e aprendizagem de uma língua estrangeira. Isto quer dizer que se a motivação do aluno em aprender a língua-alvo for grande, e a 
autoconfiança ligada à espontaneidade de uma imagem e conduta corretas durante a comunicação, frente aos colegas de sala for possível, o sucesso estará garantido.

Seguindo o mesmo raciocínio, HAVERSON (1991) afirma que falar na sala de aula é um risco que os alunos queiram ou não, todos têm que correr, uma vez que somente assim conseguirão desenvolver a fala da língua estrangeira. Quando isso acontece o professor tem condições de indicar quais foram os erros cometidos durante a comunicação, e essa informação, essa ajuda, tem o objetivo de resultar na superação das dificuldades de pronúncia.

Entretanto, há boas razões para nos preocuparmos com os erros de articulação das seqüências de fonemas nos padrões silábicos dos vocábulos da língua estrangeira, principalmente se considerarmos a questão didáticopedagógica. ElLIS (1997, p. 15) afirma que os professores costumam perguntar "Por que os estudantes cometem erros?", essa pergunta desperta no professor a curiosidade em tentar desvendar quais são esses erros, bem como buscar caminhos que levam-no a ajudar seu aluno a alcançar a aprendizagem a partir dos problemas e dificuldades lingüísticas que ele encontra ao aprender uma segunda língua.

A partir dessa consideração, nessa pesquisa iremos direcionar nosso interesse no que o aluno "pronunciou diferentemente do que seria o correto"8. Ao identificarmos os possíveis acertos ou erros dos estudantes é importante verificarmos se são 'erros' ou 'enganos', como explica ElLıs (1997) no trecho abaixo.

\footnotetext{
${ }^{8} \mathrm{O}$ vocábulo "correto" terá para esta pesquisa a definição de uma pronúncia ou adequada, ou esperada.
} 
How can we be sure that when a learner produces a deviant form it is not just an accidental slip of the tongue? After all, native speakers often make slips when they are tired or under some kinds of pressure to communicate. We need to distinguish errors and mistakes. Errors reflect gaps in the learner's knowledge; they occur because the learner does not know what is correct. Mistakes reflect occasional lapses in performances; they occur because, in a particular instance, the learner is unable to perform what he or she knows. [...] Where they are unable to, deviations are errors; where they are successful, they are mistakes. (ELLIS, 1997, p. 17)

Após a identificação dos erros ou enganos devemos passar para a fase da descrição e da classificação dos tipos encontrados, o que nos direciona para a explicação do porquê de todas as ocorrências. O resultado segue geralmente o seguinte padrão: ao identificar os erros percebemos que de uma certa forma eles são sistemáticos, previsíveis e universais; aqueles que não são universais ocorrem ao mesmo grupo de pessoas que falam a mesma língua nativa e que, portanto, cometem os mesmos tipos de erros.

Segundo Schütz (2004a) o professor deverá estar atento às dificuldades do seu aluno e tentar ajudá-lo explicando como os fonemas problemáticos são produzidos, contrastando-os com os da língua materna, por exemplo. Esse procedimento levará o aluno a perceber as diferenças existentes entre os pontos de articulação que são muito próximos. Poedjosoedarmo (2004) completa essa afirmação dizendo que todas as formas de esclarecimento são necessárias para o aluno entender como deverá ser realizada a produção final dos vocábulos para se aproximar a do falante nativo.

É importante ressaltar que somente conhecer o sistema fonológico da língua estrangeira não faz com que o aluno saiba produzir todos os 
fonemas corretamente. Esse conhecimento traz apenas a informação necessária para iniciar um trabalho árduo.

Segundo HARMER (1994) há outros aspectos que podem interferir e influenciar também na aquisição fonológica da língua estrangeira. Dentre esses os mais importantes são as habilidades cognitivas e a motivação. Para ilustrar esses dois aspectos ele cita que há a facilidade de memorizar e lembrar a seqüência de letras de um vocábulo escrito ou mesmo os padrões silábicos e os símbolos fonéticos; e, a vontade ou necessidade do estudante em se aprimorar para manter uma comunicação clara.

De acordo com ScHütz (2003b) para que o estudante adquira a fonologia da segunda língua com sucesso, o grau de esforço do aluno está diretamente relacionado à motivação em estudar e aprender a língua estrangeira.

A motivação do aluno pode ser variada, ele pode ter ou uma razão funcional, ou o objetivo de passar num exame, ou conseguir um novo emprego, ou entrar para a universidade (HARMER, 1994; RUBin \& THompson, 2001). Ele também pode estar interessado apenas em aprender mais sobre o povo e a cultura da língua-alvo. Ou ainda pode perceber que o resultado alcançado durante seu aprendizado foi bom e isso motivá-lo a melhorar, a aprender mais.

Para KRASHen (1988) o estudo de uma língua estrangeira sempre que possível deve ser individualizado, pensando sempre no que motivará mais o aluno a aprender.

Neste mesmo sentido, a experiência de maior ou menor sucesso no aprendizado de uma segunda língua, conforme HARMER (1994), também pode 
trazer um reconhecimento relacionado com o nível de discriminação social ou cultural.

Além disso, a motivação pode ser um fenômeno complexo se considerarmos as atitudes positivas ou negativas com relação ao grupo que fala a língua-alvo.

Enfim, a motivação é o sentimento do estudante com relação à aquisição da língua estrangeira confundida com as atividades de aprendizado que a envolvem. 


\subsection{As Sílabas Inglesa e Portuguesa}

Abordar o sistema fonológico de uma língua significa tratar da sua produção oral, em que se define 'consoante', 'vogal' e 'semivogal'. Além disso, é necessário determinar o papel de cada um deles na estrutura silábica.

Em relação à estrutura silábica, segundo CÂmARA JR. (1971) quando a sílaba é completa, a vogal é o ápice enquanto que as consoantes são consideradas respectivamente o aclive e o declive, pois podem ser facultativas ao ocorrer entre a vogal (Figura 1).

Pensando desta maneira, podemos dizer que a estrutura interna da sílaba consiste em um núcleo constituído por uma vogal $(=\mathrm{V})^{9}$ ou um ditongo ${ }^{10}$, enquanto que as posições periféricas são ocupadas pelas consoantes $(=C)$ antes e/ou depois do núcleo. Então, podemos afirmar que a vogal é o fator determinante na constituição da sílaba, pois podemos ter uma sílaba com ou sem consoante. Mas não há sílaba (inglesa ou portuguesa) sem som vocálico ${ }^{11}$.

Figura 1: Estrutura da Sílaba

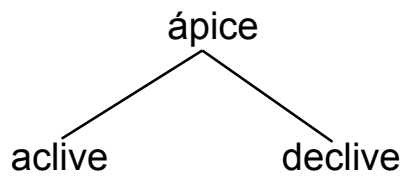

Assim, tanto em inglês como em português as consoantes ocupam as partes periféricas do núcleo da sílaba. Em ambas as línguas em questão a vogal é parte obrigatória na estrutura silábica, o núcleo pode ser

\footnotetext{
${ }^{9}$ Ou mesmo uma vogal longa, no caso do Inglês.

${ }^{10}$ Os ditongos são formados por uma vogal e uma semivogal. Para essa pesquisa consideraremos a semivogal que ocorre no ditongo como um fonema vocálico.

${ }^{11}$ Há possibilidade também de ocorrer em inglês fonemas consonantais que são considerados vocálicos tais como: / $\mathrm{mnnIr/.}$
} 
simples com apenas uma vogal ou complexo de mais de uma vogal, enquanto que a consoante é parte facultativa tanto o inglês como no português.

Assim a fala divide-se em segmentos, os quais podem ser agrupados numa variedade bastante grande de seqüências, quer seja a língua inglesa ou portuguesa. Para que pudéssemos estudar e entender a fala com suas diferentes possibilidades de agrupamentos, foi criada uma representação mental da fala que inclui o sistema fonológico de uma língua e o seu conjunto de fonemas, os quais são utilizados na fala. Desta forma, cada letra, cada som, tem sua própria representação, aliada aos padrões silábicos específicos de cada língua, seja ela a linguagem escrita ou oral.

Ao considerarmos que cada língua admite determinados modelos de sílabas, nos Quadros 1 e 2 mostramos as possibilidades das sílabas inglesa e portuguesa. Qualquer fonema representado por uma letra em caixa alta refere-se ao arquifonema ${ }^{12}$ da língua portuguesa, sendo os vocábulos utilizados como exemplos escolhidos por nós.

Para o contraste dos padrões silábicos do inglês e do português, iremos nos deter, sempre que possível, na transcrição fonológica para descrever as seqüências de fonemas no início ou no final do vocábulo.

\footnotetext{
12 "Arquifonema: é o conjunto de particularidades distintivas comuns a dois fonemas, cuja oposição é neutralizável. [...]" (DuboIs, 1973, p.65). Pode ser um fonema consonantal ou vocálico.
} 
Quadro 1: Sílabas Inglesa e Portuguesa

\begin{tabular}{|c|c|c|}
\hline \multicolumn{3}{|c|}{ Sílabas } \\
\hline Padrão & Inglesa & Portuguesa \\
\hline CCV- & pronounce / prə- / & prefixo / pre- / \\
\hline CVC & $\underline{\text { bed / bed / }}$ & $\underline{\text { mas / maS / }}$ \\
\hline
\end{tabular}

Nos vocábulos monossilábicos do português, possivelmente produzidos como na transcrição no Quadro 2, por seus respectivos falantes nativos, temos dois fonemas consonantais que antecedem e também outros que são posteriores ao núcleo.

Quadro 2: Sílaba CCVCC Inglesa e Portuguesa

\begin{tabular}{|c|c|c|}
\hline \multicolumn{3}{|c|}{ Sílabas } \\
\hline Padrão & Inglesa & Portuguesa \\
\hline CCVCC & crimes / kraimz / & trens / treiNS / ${ }^{13}$ \\
\hline
\end{tabular}

Cada língua possui características próprias e também padrões silábicos próprios, os quais permitem que um determinado número de segmentos se combine formando um constituinte silábico. Desta forma podemos afirmar que cada língua possui um número de padrões silábicos possíveis.

Ao compararmos as sílabas inglesa e portuguesa, podemos discutir as semelhanças e as diferenças existentes nas sílabas de ambas as

\footnotetext{
${ }^{13} \mathrm{Na}$ transcrição do vocábulo português 'trens' a vogal 'e' é seguida de consoante nasal. Nesse caso o 'N' foi utilizado como um arquifonema, representando a nasalização da vogal ' $i$ '. O mesmo vocábulo poderia ter sido transcrito foneticamente: [ trejs ].
} 
línguas. Para tanto basearemos esse contraste em alguns autores que descrevem a língua portuguesa (CÁmara JR., 1970, 1971 e 1972; Silveira, 1986 e 1988; Bisol, 2001; Ferreira Netto, 2001; Cristófaro-Silva, 2002 e 2003;); os que descrevem a língua inglesa (Gleason, 1961; Gimson, 1962; O’Connor, 1980; Odlin, 1989; e Roach, 1983; Kenworthy, 1990; Jones, 1997; Hewings \& Goldstein, 2000); e os que contrastam ambas as línguas (Azevedo, 1981; Steinberg, 1985 e 2006; Sant'Anna, 1997, 2003 e 2004; Schumaker, White \& ZanettinI, 2002; Schütz, 2004b e 2005).

Na literatura há uma nomenclatura mais recente nos estudos fonéticos e fonológicos. Por exemplo, podemos citar Bısol (2001) ${ }^{14}$ que afirma que a sílaba pode ser caracterizada como leve ou pesada. Para a autora, a sílaba leve contém apenas uma vogal, já a sílaba pesada pode conter uma vogal mais uma consoante, ou ainda conter dois elementos vocálicos, os quais podem ser caracterizados por um ditongo ou por uma vogal longa. Entretanto para analisar e discutir os dados dessa pesquisa utilizaremos o modelo de sílaba de Câmara JR (1971), uma vez que acreditamos que esse modelo é mais apropriado para analisar e discutir os dados da presente pesquisa.

\footnotetext{
${ }^{14}$ Leda Bisol aborda em suas obras a perspectiva de uma teoria não-linear.
} 


\subsubsection{Padrões Silábicos}

Para melhor entendermos os fonemas e suas combinações que obedecem aos critérios e aos padrões de cada língua, realizaremos um contraste fonético-fonológico das possibilidades existentes de padrões das sílabas inglesa e portuguesa.

Nos padrões silábicos da língua inglesa, descritos no Quadro 3, há predominância de vocábulos monossilábicos, uma vez que nessa língua ocorre uma grande quantidade de vocábulos com essa característica.

Ainda no Quadro 3, podemos verificar diferentes padrões silábicos para o vocábulo inglês, seja no início ou no final da sílaba. Entretanto, sabemos que apenas o fonema consonantal nasal / - 1 / não ocorre como primeiro fonema de nenhum vocábulo inglês. 
Quadro 3: Padrões Silábicos Ingleses

\begin{tabular}{|c|c|c|}
\hline $\begin{array}{l}\text { Padrões } \\
\text { Silábicos }\end{array}$ & $\begin{array}{c}\text { Vocábulos } \\
\text { Ingleses }\end{array}$ & $\begin{array}{l}\text { Transcrição } \\
\text { Fonológica } \\
\end{array}$ \\
\hline VVC & ache & / eik / \\
\hline $\mathbf{V V}$ & $I$ & I a I \\
\hline VC & of & I ov I \\
\hline V & $a$ & I ə / (weak form) \\
\hline CVVCC & coast & / koust I \\
\hline CVVC & like & I lark I \\
\hline CVV & day & / der / \\
\hline CVCCC & sixth & / siks $\theta$ / \\
\hline CVCC & sand & / sænd / \\
\hline CVC & sick & / sik / \\
\hline $\mathrm{CV}$ & the & / бә / or / бг / \\
\hline CCVVCC & grapes & / greips / \\
\hline ccVvc & broom & / bru:m / \\
\hline ccVV & dry & / drai I \\
\hline ccveccc & twelfths & I twelf $\theta$ s I \\
\hline CCVCC & drunk & / dr^nk I \\
\hline CCVC & plan & I plæn I \\
\hline $\mathrm{CCV}$ & brigade & I brr- I \\
\hline cccvvcc & screams & / skri:mz I \\
\hline cccVve & screen & / skri:n / \\
\hline CCCVV & straw & / stro: I \\
\hline CCCVCCCC & strengths & / strenk $\theta$ s / \\
\hline cccve & splash & / splæ / I \\
\hline
\end{tabular}

No português brasileiro não podemos exemplificar a ocorrência de todos os padrões silábicos em vocábulos monossilábicos, sendo necessário para exemplificá-los lançar mão de vocábulos dissílabos, trissílabos ou polissílabos. Assim, sublinharemos os padrões silábicos dos vocábulos de mais de uma sílaba para melhor entendimento (Quadro 4). 
Quadro 4: Padrões Silábicos Portugueses

\begin{tabular}{|c|c|c|}
\hline $\begin{array}{l}\text { Padrões } \\
\text { Silábicos }\end{array}$ & $\begin{array}{l}\text { Vocábulos } \\
\text { Portugueses }\end{array}$ & $\begin{array}{l}\text { Transcrição } \\
\text { Fonológica }\end{array}$ \\
\hline VVC & ais & / aIS / \\
\hline VV & eu & / ew / \\
\hline VC & os & 1 of 1 \\
\hline $\mathbf{v}$ & é & $|\varepsilon|$ \\
\hline CVV & sei & / sei/ \\
\hline CVCC & tórax & / -raks / \\
\hline CVC & par & / par I \\
\hline CV & pé & $/ p \varepsilon /$ \\
\hline ccVvc & $\begin{array}{c}\text { claustrofobi } \\
a\end{array}$ & / klaus / \\
\hline CCVV & flauta & / flau- I \\
\hline ccvec & transcrito & / traNs- / \\
\hline CCVC & plasma & / plas- / \\
\hline CCV & fruta & / fru- / \\
\hline
\end{tabular}

Ao observar o Quadro 4 verificamos que a sílaba portuguesa pode iniciar por um, dois fonemas, ou mesmo iniciar o vocábulo por um fonema vocálico. Devemos ressaltar ainda que as vogais do português podem ser orais ou nasais, respectivamente, / a e $\varepsilon$ I $\supset$ o u / e / ã ẽ ĩ õ ũ /.

A consoante nasal que ocorre após o fonema vocálico na estrutura silábica, será representada nas transcrições fonológicas de nossa amostra, pelo arquifonema / N /, ou seja, a letra em maiúscula é a neutralização 
de um fonema não marcado (CÂmARA JR., 1970) ${ }^{15}$, gerando / aN /, / eN /, / $\mathrm{iN} /$, / oN /, ou / uN /.

Como podemos observar no Quadro 5, a lista de padrões silábicos do português é menor que a do inglês.

Esta característica da língua inglesa pode trazer dificuldade para o falante do português no que diz respeito ao número de fonemas consonantais de alguns vocábulos, principalmente porque não estamos habituados a produzir algumas dessas seqüências diferentes de consoantes, nem no início e nem no final da sílaba.

Segundo os pesquisadores Lado (1957); AzeVedo (1981); Fernandes (1997); Steinberg (1985 e 2006); Schumaker, White \& Zanettini (2002); Sant'Anna (2003, 2004 e 2005); Cristófaro-Silva (2003), no início do aprendizado quando temos que articular os diferentes tipos de padrões silábicos da língua inglesa, com várias consoantes antes da vogal ou mesmo depois dela, nós falantes da língua portuguesa, geralmente acrescentamos uma vogal epentética ${ }^{16}$, para apoiar o primeiro ou o último fonema consonantal da sílaba.

\footnotetext{
${ }^{15}$ Citamos neste trecho Câmara Jr. (1970), pois esse é o modelo de sílaba que nos baseamos para descrever os dados de nossa amostra.

${ }^{16}$ Vogal epentética: ocorre quando há intercalação de fonema não etimológico no interior de um vocábulo por acomodação articulatória, eufonia, analogia etc.
} 
Quadro 5: Contraste dos Padrões Silábicos Ingleses e Portugueses

\begin{tabular}{|c|c|}
\hline \multicolumn{2}{|c|}{ Padrões Silábicos } \\
\hline Inglês & Português \\
\hline VVC & VVC \\
\hline VV & VV \\
\hline VC & VC \\
\hline $\mathbf{V}$ & $\mathbf{V}$ \\
\hline CVVCC & -- \\
\hline CVVC & -- \\
\hline CVV & CVV \\
\hline CVCCC & -- \\
\hline CVCC & CVCC \\
\hline CVC & CVC \\
\hline CV & CV \\
\hline ccVvcc & - \\
\hline ccVvc & cCVVC \\
\hline CCVV & CCVV \\
\hline ccveccc & -- \\
\hline cCVCC & CCVCC \\
\hline CCVC & CCVC \\
\hline CCV & CCV \\
\hline cccVvcc & -- \\
\hline cccVvc & -- \\
\hline cccVV & -- \\
\hline CcCVCCCC & -- \\
\hline
\end{tabular}

Este aspecto relacionado aos padrões silábicos e a seqüência de vários fonemas na mesma sílaba, que diferencia as duas línguas envolvidas nesse estudo, como já dissemos anteriormente é um fato que merece atenção. Dada a quantidade de vocábulos ingleses que possuem tantas diferenças de padrões silábicos, temos como uma das hipóteses para essa pesquisa 
observacional demonstrar que esse fato pode ocasionar interferências no ato da fala, no início do aprendizado da língua estrangeira.

- Língua Inglesa - padrões silábicos

Os encontros consonantais iniciais ou mesmo os finais em inglês podem gerar muitas combinações. Devemos esclarecer que nos Quadros de 6 a 12 apresentaremos as possíveis distribuições dos fonemas consonantais nas sílabas. Segundo O'Connor (1980) há algumas possibilidades de combinação de duas ou três consoantes no início da sílaba do vocábulo inglês, as quais destacaremos nos Quadros 6 e 7. 
Quadro 6: Seqüência de Dois Fonemas no Início do Vocábulo Inglês

\begin{tabular}{|c|c|c|c|c|c|}
\hline $\begin{array}{c}\text { Fonema } \\
\text { inicial }\end{array}$ & $\begin{array}{c}+ \\
\text { Fonema }\end{array}$ & $\begin{array}{c}\text { Vocábulos } \\
\text { ingleses }\end{array}$ & $\begin{array}{c}\text { Fonema } \\
\text { inicial }\end{array}$ & $\begin{array}{c}+ \\
\text { Fonema }\end{array}$ & $\begin{array}{c}\text { Vocábulos } \\
\text { ingleses }\end{array}$ \\
\hline$|\mathrm{s}|$ & $\begin{array}{l}\text { / sp- / } \\
\text { / st- / } \\
\text { / sk- / } \\
\text { / sf- / } \\
\text { / sm- / } \\
\text { / sn- / } \\
\text { / st- / } \\
\text { / sw- / } \\
\text { / sj- / }\end{array}$ & $\begin{array}{c}\text { spin } \\
\text { stand } \\
\text { sky } \\
\text { sphere } \\
\text { smile } \\
\text { snake } \\
\text { slim } \\
\text { swim } \\
\text { suit }\end{array}$ & $/ \mathrm{p} /$ & $\begin{array}{l}/ \mathrm{pl}-/ \\
/ \mathrm{pr}-/ \\
/ \mathrm{pj}-/\end{array}$ & $\begin{array}{l}\text { plant } \\
\text { pray } \\
\text { pure }\end{array}$ \\
\hline$/ \mathrm{t} /$ & $\begin{array}{l}/ \mathrm{tr}-/ \\
/ \mathrm{tw}-/ \\
/ \mathrm{tj}-/\end{array}$ & $\begin{array}{l}\text { tray } \\
\text { twin } \\
\text { tune }\end{array}$ & / k / & $\begin{array}{l}\text { / kl- / } \\
/ \mathrm{kr}-/ \\
/ \mathrm{kw}-/ \\
/ \mathrm{kj}-/\end{array}$ & $\begin{array}{c}\text { climb } \\
\text { create } \\
\text { quote } \\
\text { cure }\end{array}$ \\
\hline$/ \mathrm{b} /$ & $\begin{array}{l}\text { / bl- / } \\
/ \mathrm{br}-/ \\
/ \mathrm{bj}-/\end{array}$ & $\begin{array}{c}\text { blank } \\
\text { brown } \\
\text { beautiful }\end{array}$ & $/ \mathrm{d} /$ & $\begin{array}{l}/ \mathrm{dr}-/ \\
/ \mathrm{dw}-/ \\
/ \mathrm{dj}-/\end{array}$ & $\begin{array}{l}\text { drink } \\
\text { dwell } \\
\text { duty }\end{array}$ \\
\hline $\mathrm{lg} /$ & $\begin{array}{l}\text { / gl- / } \\
\text { / gr- / }\end{array}$ & $\begin{array}{l}\text { glad } \\
\text { great }\end{array}$ & $/ \mathrm{f} /$ & $\begin{array}{l}\mathrm{fl}-/ \\
/ \mathrm{fr}-/ \\
/ \mathrm{fj}-/\end{array}$ & $\begin{array}{c}\text { flight } \\
\text { fry } \\
\text { few }\end{array}$ \\
\hline$|\theta|$ & $\begin{array}{l}\theta \mathrm{r}-/ \\
/ \theta \mathrm{w}-/\end{array}$ & $\begin{array}{c}\text { through } \\
\text { thwart }\end{array}$ & $1 \int 1$ & $/ \mathrm{Sr}-1$ & shrimp \\
\hline$|\mathrm{v}|$ & / vj- I & view & $/ \mathrm{m} /$ & / mj- / & mute \\
\hline$/ \mathrm{n} /$ & / nj- / & new & $/ \mathrm{h} /$ & / hj- / & human \\
\hline
\end{tabular}


Quadro 7: Seqüência de Três Fonemas no Início do Vocábulo Inglês

\begin{tabular}{|c|c|c|}
\hline $\begin{array}{c}\text { Fonema } \\
\text { inicial }\end{array}$ & $\begin{array}{c}+ \\
\text { Fonema }\end{array}$ & $\begin{array}{c}\text { Vocábulos } \\
\text { ingleses }\end{array}$ \\
\hline & / spr-/ & spring \\
& $/$ str-/ & street \\
& $/$ skr-/ & scream \\
& / spj- / & spurious \\
/ s / & / stj-/ & stupid \\
& / skj- / & skewer \\
& / spl- / & splash \\
& / skw- / & squeak \\
\hline
\end{tabular}

Os exemplos do Quadro 8 referem-se ao estudo que apresenta os padrões silábicos e suas respectivas seqüências de fonemas consonantais da língua inglesa ${ }^{17}$ realizado por StEINBERg (1985 e 2006), no qual há vocábulos, em sua maioria monossílabos, contendo dois ou mais fonemas consonantais finais.

\footnotetext{
${ }^{17}$ Nesse estudo, Steinberg (1985) considera a pronúncia Norte-Americana padrão, por isso há várias seqüências de fonemas em final de sílaba iniciadas por / $-r$ /.
} 
Quadro 8: Seqüência de Fonemas em Final de Vocábulo Simples (Inglês)

\begin{tabular}{|c|c|}
\hline $\begin{array}{c}\text { Fonemas } \\
\text { finais }\end{array}$ & $\begin{array}{c}\text { Vocábulo } \\
\text { Inglês }\end{array}$ \\
\hline / -nd / & sound \\
\hline$/$-nt / & plant \\
\hline$/$-st / & last \\
\hline / -ns / ou / -nts / & defense \\
\hline$/$-ld / & cold \\
\hline$/$-ks / & socks \\
\hline$/$-lf / & golf \\
\hline$/$-nk / & think \\
\hline$/$-kt / & fact \\
\hline$/$-nd3 / & change \\
\hline$/$-lv / & solve \\
\hline$/$-lt / & felt \\
\hline$/$-sk / & task \\
\hline$/$-ln / & kiln \\
\hline$/$-rb / & herb \\
\hline$/$-rd / & beard \\
\hline$/$-rf / & surf \\
\hline$/$-rg / & iceberg \\
\hline$/$-rd3 / & large \\
\hline$/$-rt / & search \\
\hline$/$-rk / & shark \\
\hline$/$-rl / & pearl \\
\hline
\end{tabular}

\begin{tabular}{|c|c|}
\hline $\begin{array}{l}\text { Fonemas } \\
\text { finais }\end{array}$ & $\begin{array}{l}\text { Vocábulo } \\
\text { Inglês }\end{array}$ \\
\hline | -rz / & furze \\
\hline$/-\operatorname{lp} /$ & help \\
\hline / -ls / & false \\
\hline / -lk / & folk \\
\hline / - I $\theta$ / ou / - It $\theta$ / & health \\
\hline / -mp / & lamp \\
\hline / -nt $\int /$ & bench \\
\hline / -ft / & gift \\
\hline / -sp / & crisp \\
\hline / - Im / & calm \\
\hline / -ldz / & indulge \\
\hline / -lb / & bulb \\
\hline $1-15 /$ & Welch \\
\hline / -dz / & adze \\
\hline I -rs / & marsh \\
\hline | -r $\theta$ / & earth \\
\hline / -rps / & corpse \\
\hline / -rst / & thirst \\
\hline / -rts / & quartz \\
\hline / -mpt / & prompt \\
\hline / -mps / & glimpse \\
\hline$/-\operatorname{tt} \int /$ & belch \\
\hline
\end{tabular}

Continua... 


\begin{tabular}{|c|c|c|c|}
\hline $\begin{array}{c}\begin{array}{c}\text { Fonemas } \\
\text { finais }\end{array} \\
\end{array}$ & $\begin{array}{l}\text { Vocábulo } \\
\text { Inglês }\end{array}$ & $\begin{array}{c}\begin{array}{c}\text { Fonemas } \\
\text { finais }\end{array} \\
\end{array}$ & $\begin{array}{l}\text { Vocábulo } \\
\text { Inglês }\end{array}$ \\
\hline / -rm / & form & / -mf / ou / -mpf / & triumph \\
\hline / -rn / & burn & /-ps / & copse \\
\hline / -rp / & burp & / -pt / & script \\
\hline / -rs / & course & / -nz / & Lenz \\
\hline / -rt / & part & / -kst / & text \\
\hline / -rv / & starve & / -nks / & sphinx \\
\hline
\end{tabular}

Nos Quadros 9, 10, 11 e 12 apresentamos as derivações morfológicas, ou seja, mostraremos que alguns padrões silábicos do inglês decorrem de acréscimos morfológicos e/ou gramaticais, os quais modificam a estrutura silábica inicial. Quanto às seqüências de fonemas consonantais ingleses em final de vocábulo, é possível obtermos uma seqüência de até quatro fonemas consonantais. Para tanto temos ainda que distinguir dois tipos de combinação que podem ocorrer na língua inglesa: com ou sem acréscimo de um outro morfema (sufixos: derivacional e inflexional).

Há os vocábulos com sufixos derivacionais (Quadro 9), que a partir da adição de um morfema podem modificar a categoria gramatical do vocábulo. 
Quadro 9: Seqüência de Fonemas em Final de Vocábulo com Sufixo Derivacional (Inglês)

\begin{tabular}{|c|c|}
\hline Fonemas finais & Vocábulo Inglês \\
\hline$/-|\theta|$ & health \\
\hline$/-d \theta /$ & width \\
\hline$/-n \theta$ / & tenth \\
\hline / -f $\theta$ / & fifth \\
\hline$/-\mathrm{t} \theta /$ & eighth \\
\hline $\mid-r \theta /$ & fourth \\
\hline / -ks $\theta /$ & sixth \\
\hline / -nd $\theta$ / & thousandth \\
\hline / -If日 / & twelfth \\
\hline / -rmp $\theta$ / & warmth \\
\hline
\end{tabular}

No Quadro 10 há outros vocábulos com sufixo inflexional, que a partir da adição de um morfema de $3^{a}$ pessoa do singular do presente, pode modificar sua produção final para / s /, / z / ou / Iz /, dependendo do fonema final antes do acréscimo do sufixo. 
Quadro 10: Seqüência de Fonemas em Final de Vocábulo com Sufixo Inflexional (Inglês)

\begin{tabular}{|c|c|c|c|}
\hline $\begin{array}{c}\text { Fonemas } \\
\text { finais }\end{array}$ & $\begin{array}{l}\text { Vocábulo } \\
\text { Inglês }\end{array}$ & $\begin{array}{c}\text { Fonemas } \\
\text { finais }\end{array}$ & $\begin{array}{l}\text { Vocábulo } \\
\text { Inglês }\end{array}$ \\
\hline / -fs / & laughs & / -bz / & robs \\
\hline / -ps / & stops & $|-g z|$ & begs \\
\hline / -ts / & shouts & $|-| z \mid$ & falls \\
\hline / -fts / & lifts & $/-m z /$ & crimes \\
\hline / -kts / & acts & | -vz / & lives \\
\hline / -Ifs / & engulfs & / -nz / & belongs \\
\hline / -Iks / & talks & / -nz / & cleans \\
\hline / -Ips / & helps & $/-\operatorname{ldz} /$ & folds \\
\hline / -Its / & melts & / -Ims / & films \\
\hline / -nks / & thanks & / -Ivz / & solves \\
\hline / -sks / & tasks & / -rbz / & disturbs \\
\hline / -sps / & lisps & / -rdz / & boards \\
\hline / -sts / & interests & | -rlz / & curls \\
\hline / -mpts / & tempts & / -rmz / & harms \\
\hline / -rks / & works & / -rnz / & burns \\
\hline / -rps / & warps & / -rvz / & starves \\
\hline / -rsts / & bursts & & \\
\hline
\end{tabular}

Há ainda outros vocábulos com sufixo inflexional no Quadro 11, que a partir da adição de um morfema de plural dos substantivos, pode modificar sua articulação. Esse aspecto ocorre para a adição de $\mathbf{- s}$ ou -es para a formação de vocábulos no plural. 
Quadro 11: Seqüência de Morfemas de Plural dos Substantivos em Final de Vocábulo (Inglês)

\begin{tabular}{|c|c|c|c|}
\hline $\begin{array}{c}\text { Fonemas } \\
\text { finais }\end{array}$ & $\begin{array}{l}\text { Vocábulo } \\
\text { Inglês }\end{array}$ & $\begin{array}{c}\text { Fonemas } \\
\text { finais }\end{array}$ & $\begin{array}{l}\text { Vocábulo } \\
\text { Inglês }\end{array}$ \\
\hline$/$-fs / & cliffs & 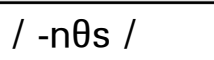 & tenths \\
\hline / -ts / & hats & / -nks / & sinks \\
\hline $\mid-\theta s /$ & deaths & / -pts / & scripts \\
\hline / -dths / & widths & / -sks / & tasks \\
\hline / -fts / & gifts & / -sps / & wasps \\
\hline / -f $\theta \mathrm{s} /$ & fifths & / -sts / & fists \\
\hline / -kts / & acts & / -t $\theta \mathrm{s} /$ & eighths \\
\hline / -Ifs / & gulfs & / -ksts / & texts \\
\hline / -Iks / & bulks & / -ks $\theta \mathrm{s} /$ & sixths \\
\hline / -Ips / & gulps & / -If $\theta \mathrm{s} /$ & twelfths \\
\hline / -Its / & belts & / -mpts / & attempts \\
\hline$/-|\theta s|$ & wealths & / -nd $\theta$ s / & thousandths \\
\hline / -mfs / & nymphs & / -nkधs / & strengths \\
\hline / -rfs / & surfs & | -vz I & saves \\
\hline / -rks / & parks & $|-\eta z z|$ & songs \\
\hline / -rps / & corps & / -lbz / & bulbs \\
\hline$|-g z|$ & dogs & / -ldz / & folds \\
\hline$|-| z \mid$ & bells & / - Imz / & elms \\
\hline / -mz / & rooms & I -Ivz I & halves \\
\hline
\end{tabular}

E, ainda há os verbos regulares que a partir da adição do morfema -d ou -ed aos vocábulos, também podem modificar sua articulação final (Quadro 12). 
Quadro 12: Seqüência de Fonemas em Final de Vocábulo dos Verbos Regulares (Inglês)

\begin{tabular}{|c|c|c|c|}
\hline $\begin{array}{l}\text { Fonemas } \\
\text { finais }\end{array}$ & $\begin{array}{l}\text { Vocábulo } \\
\text { Inglês }\end{array}$ & $\begin{array}{c}\text { Fonemas } \\
\text { finais }\end{array}$ & $\begin{array}{l}\text { Vocábulo } \\
\text { Inglês }\end{array}$ \\
\hline / -bd / & disturbed & $/-\int \mathrm{t} /$ & wished \\
\hline$/ \operatorname{lgd} /$ & jogged & / -rd3d / & charged \\
\hline / -dzd / & judged & / -rld / & curled \\
\hline / -md / & aimed & / -rmd / & formed \\
\hline /-nds / & stringed & / -rnd / & burned \\
\hline / -ðd / & bathed & / -rvd / & observed \\
\hline / -Imd / & filmed & $/-3 d /$ & rouged \\
\hline / -lvd / & solved & / -vd / & waved \\
\hline / -ndzd / & changed & / -zd / & realized \\
\hline /-rbd / & curbed & / -ldzd / & indulged \\
\hline$/$ - t $\int \mathrm{t} /$ & touched & / -kst / & mixed \\
\hline$/-1 \mathrm{ft} /$ & gulfed & / -pst / & elapsed \\
\hline$/$ - It $\int \mathrm{t} /$ & welched & / -lkt / & walked \\
\hline / -nt $\int \mathrm{t} /$ & crunched & / -lpt / & helped \\
\hline / -nst / & danced & / - Itst / & waltzed \\
\hline / -nkt / & linked & $/-\mathrm{mft} /$ & triumphed \\
\hline
\end{tabular}

Notamos pelas possibilidades descritas que há uma variedade muito grande de combinações de fonemas consonantais que podem ocorrer no idioma inglês, o que é uma característica da sílaba inglesa. 
- Língua Portuguesa - padrões silábicos

Ao considerarmos as seqüências de fonemas consonantais iniciais ou finais da língua portuguesa notamos que há várias combinações possíveis. No Quadro 13 apresentaremos as possibilidades de combinação de duas consoantes no início da sílaba do vocábulo português, segundo SILVEIRA (1988). 
Quadro 13: Seqüência de Dois Fonemas no Início do Vocábulo Português

\begin{tabular}{|c|c|c|}
\hline $\begin{array}{c}\text { Fonema } \\
\text { inicial }\end{array}$ & + Fonema & $\begin{array}{c}\text { Vocábulos } \\
\text { portugueses }\end{array}$ \\
\hline \multirow[b]{2}{*}{$/ \mathrm{p} /$} & / pl- / & planta \\
\hline & / pr- / & praia \\
\hline \multirow[b]{2}{*}{$/ \mathrm{t} /$} & / tl- / & atleta \\
\hline & / tr- / & truque \\
\hline \multirow[b]{2}{*}{$/ \mathrm{k} /$} & / kl- / & classe \\
\hline & / kr- / & cravo \\
\hline \multirow[b]{2}{*}{ / b / } & / bl- / & blefe \\
\hline & / br- / & bravo \\
\hline \multirow[b]{2}{*}{$/ \mathrm{d} /$} & / dl- / & pedra \\
\hline & $/ d r-1$ & dragão \\
\hline \multirow[b]{2}{*}{ lg / } & / gl- / & glacê \\
\hline & / gr- / & alegre \\
\hline \multirow[b]{2}{*}{ /f / } & / fl- / & flanela \\
\hline & / fr- / & fraco \\
\hline \multirow[b]{2}{*}{ / v / } & / vl- / & Vlamir \\
\hline & / vr- / & livrar \\
\hline
\end{tabular}

Quanto aos encontros consonantais em final de sílaba, há a possibilidade de termos também dois fonemas consonantais do ponto de vista fonológico. Eles não ocorrem com freqüência na língua portuguesa e podem se realizar apenas nas combinações dos seguintes fonemas: /R / + / S / e / L / + I S /. Esses encontros consonantais podem ser articulados sem vogal de apoio. Vale lembrar que SILVEIRA (1988, p. 91) acrescenta que "foneticamente pode ocorrer um encontro vocálico no caso do vocábulo ‘solstício' [ sows'tisju ], resultando no processo de vocalização do / L /". 
Os arquifonemas podem ter variantes, tais como / R / - [ r x r ];

/ L / - [ \$ w ]; e, / S / - [ s z J 3 ] (Quadro 14).

Quadro 14: Seqüência de Fonemas em Final de Sílaba (Português)

\begin{tabular}{|c|c|}
\hline $\begin{array}{c}\text { Fonemas em } \\
\text { final de sílaba }\end{array}$ & $\begin{array}{c}\text { Vocábulo no } \\
\text { Português }\end{array}$ \\
\hline$/$-RS / & perspectiva \\
\hline$/$-LS / & solstício \\
\hline \multicolumn{2}{|c|}{ (adaptado de Silveira, 1988, p. 89) } \\
\hline
\end{tabular}

Há encontros consonantais que apresentam dificuldades para os falantes da língua portuguesa, o que nos faz articular os fonemas com uma vogal de apoio, ou epentética. Esse aspecto da língua portuguesa pode ser considerado como uma seqüência fonológica que, se analisada do ponto de vista fonético deverá ser considerada de outra maneira. Isto é, na descrição fonética a vogal de apoio aparecerá transcrita, demonstrando o local exato em que a vogal é inserida no momento da produção do vocábulo.

No Quadro 15 apresentamos apenas a descrição fonológica dessas seqüências de fonemas. 
Quadro 15: Seqüência de Fonemas no Início ou no Final de Sílaba (Português)

\begin{tabular}{|c|c|}
\hline $\begin{array}{c}\text { Encontros } \\
\text { consonantais }\end{array}$ & $\begin{array}{c}\text { Vocábulo no } \\
\text { Português }\end{array}$ \\
\hline$/ \mathrm{ps} /-\left[\mathrm{p}^{i} \mathrm{~s}\right]$ & bíceps \\
\hline$/ \mathrm{ks} /-\left[\mathrm{k}^{\mathrm{i}} \mathrm{s}\right]$ & tórax \\
\hline$/ \mathrm{bs} /-\left[\mathrm{b}^{\mathrm{i}} \mathrm{s}\right]$ & substituir \\
\hline$/ \mathrm{ds} /$ - [ d's ] & feldspato \\
\hline$/ \mathrm{gs} /$ - [ g's ] & tungstênio \\
\hline \multicolumn{2}{|c|}{ (adaptado de Silveira, 1988, pp. 91-92) } \\
\hline
\end{tabular}

É importante lembrar que há uma descrição pormenorizada realizada por SILVEIRA (1988) sobre os padrões silábicos que têm a vogal epentética, na qual a autora enfatiza que o elemento vocálico inserido entre os fonemas consonantais é uma manifestação fonética.

Para SiLveIRA (1988, p. 91-92) o fato das oclusivas "serem ruídos que se apóiam na sibilante", fará com que o falante do português tenha dificuldade para articular as seqüências de consoantes descritas no Quadro 15. Por isso, a autora ainda explica que a vogal de apoio, produzida entre a consoante plosiva e a fricativa, deve ser transcrita foneticamente, fato esse que ocorre com freqüência em vocábulos derivados do latim:
a) / -pS / $\rightarrow$ do vocábulo 'bíceps' [ 'bisep's ]
b) / -kS / $\rightarrow$ do vocábulo 'tórax' [ 'torak's ]
c) / -bS / $\rightarrow$ do vocábulo 'substantivo' [ subistãlt [Ivu ]
d) / -dS / $\rightarrow$ do vocábulo 'adstringente' [ ad'strĩ'zẽt $\int$ I ]
e) / -gS / $\rightarrow$ do vocábulo 'tungstênio' [ tũg's'tenju ] 
Esses encontros consonantais de palavras derivadas são para a autora a realização fonética da seqüência fonológica, pois considera que tais seqüências ocorrem na mesma sílaba.

- Contraste dos Padrões Silábicos do Inglês e do Português

Os professores que ensinam inglês como segunda língua reconhecem que a dificuldade do aluno que aprende a falar a língua estrangeira não está apenas relacionada à articulação da seqüência em que os fonemas irão ocorrer, mas também se relaciona à posição dos fonemas nas seqüências.

Esse aspecto é confirmado por LADO (1957), quando elenca as seqüências dos fonemas iniciais / sp- /, / sk- / e / st- / do inglês como uma das possíveis dificuldades para o estudante de língua materna espanhola.

Seguindo essa linha de raciocínio, podemos afirmar que a mesma dificuldade ocorre para o falante do português, pois esse tipo de seqüência de fonemas iniciais não ocorre na língua portuguesa, pelo menos não da mesma forma que no inglês.

Embora a seqüência de fonemas apresentada acima por LADO (1957) possa ocorrer nas duas línguas, há uma diferença na separação das sílabas das línguas. Para a língua portuguesa, no que diz respeito as consoantes, podemos exemplificar com os vocábulos 'espiga', 'escala' e 'estado', que as seqüências pertencem a sílabas distintas, tal como podemos conferir na silabação 
'es-pi-ga', 'es-ca-la' e 'es-ta-do’. Por outro lado, na língua inglesa a seqüência nos fonemas consonantais iniciais também pode ocorrer, mas sem a separação silábica, como nos vocábulos 'speak', 'school', 'stare', cujos fonemas / sp- /, / sk- / e / st- / pertencem a mesma sílaba, mesmo porque os vocábulos são monossilábicos.

Devido ao fato de existir algumas especificidades na língua inglesa, quando consideramos a sílaba final dos vocábulos, remos detalhar as possíveis ocorrências relacionadas às particularidades fonológicas, a alofonia diferente e a proximidade fonética ${ }^{18}$.

\subsubsection{Particularidades Fonológicas da Sílaba Inglesa Final}

O -s final dos vocábulos ingleses apresenta uma particularidade fonológica. Há três diferentes produções / -s /, / -z / e / -Iz /, tanto para os substantivos no plural, como para a $3^{a}$ pessoa do singular dos verbos no presente do indicativo ou como para o caso genitivo ou possessivo.

Estas diferenças trazem dificuldades para o falante do português, conforme afirmam Steinberg (1985 e 2006) e Schumaker, White \& Zanettini (2002), uma vez que os vocábulos portugueses no plural são produzidos, de maneira geral, apenas com o fonema / -s /. A outra possibilidade de ocorrência é que se o

\footnotetext{
18 "As particularidades fonológicas são aquelas que fazem parte do sistema articulatório daquela língua especificamente, quando comparada com uma outra língua. Já a alofonia diferente entre as duas linguas pode levar o estudante a pronunciar as diferentes realizações de alguns fonemas ingleses da maneira como ele está habituado a fazê-lo em sua própria língua e talvez esse seja o problema mais difícil de superar durante o processo de aprendizagem da língua inglesa. Quanto à proximidade fonética, como o próprio vocábulo já diz, é um fonema da língua materna que possui uma articulação muito próxima ao fonema da língua estrangeira que não se realiza na língua mãe." (cf. SANT'ANNA, 2003, p. 64-67.)
} 
vocábulo seguinte iniciar por vogal, o falante do português brasileiro produzirá o fonema / -z /.

Um outro tipo de interferência que pode ocorrer é o acréscimo de uma vogal epentética antes do $\mathbf{- s}$ final. Pois, uma vez que a seqüência de fonemas é distinta entre as línguas envolvidas haverá essa possibilidade de ocorrência, resultando no acréscimo de uma sílaba.

No Quadro 16 utilizamos os substantivos ingleses cats e lives, na forma plural, como exemplos de adição de -s. Ambos apresentam a adição da vogal epentética entre as duas consoantes finais. Fato esse que demonstra a interferência da língua materna do falante do português quando acrescenta a vogal de apoio.

O terceiro vocábulo exemplificado no Quadro 16 traz uma outra possibilidade de articulação do verbo watch na terceira pessoa do singular do presente do indicativo. Especificamente para este caso o aluno ${ }^{19}$ mantém a produção muito próxima do falante nativo, uma vez que em inglês a vogal deve ser articulada. Entretanto, o aluno não foi capaz de produzir o fonema final $\mathbf{- s}$ do vocábulo corretamente.

\footnotetext{
${ }^{19}$ Utilizamos como exemplos a fala dos alunos no dia-a-dia da sala de aula.
} 
Quadro 16: Contraste de Vocábulos Ingleses

\begin{tabular}{|c|c|}
\hline \multicolumn{2}{|c|}{ Contraste de articulações de vocábulos inglesas } \\
\hline Falante nativo & Falante do português \\
\hline cats / kæts / & cats / 'kætıs / \\
\hline lives / laivz / & lives / 'laivis / \\
\hline watches /'wa:t Iz / & watches /'wa:t Is / \\
\hline
\end{tabular}

Ainda sobre as particularidades fonológicas da sílaba final inglesa, podemos afirmar que vocábulos que possuem a letra -e como última letra, não possuem articulação. Isso quer dizer que no momento da produção do vocábulo, o falante nativo sempre irá finalizar a produção da sílaba no último fonema consonantal.

A característica da língua inglesa descrita acima não ocorre na língua portuguesa. Esse aspecto trará dificuldades de articulação das sílabas finais por falantes do português, resultando no acréscimo de uma vogal epentética no final do vocábulo. Por isso, no início do aprendizado da língua inglesa, o aluno acrescenta a vogal epentética nos vocábulos que terminam com a letra -e.

Há também três diferentes ocorrências do passado regular -ed dos verbos em inglês, / -t /, / -d / ou / -Id /. Nos exemplos abaixo (Quadro 19) apresentaremos as possíveis articulações dos verbos regulares pelos falantes do português brasileiro.

Assim, veremos que o fato de existir na grafia de alguns verbos regulares a vogal final -e, faz com que o falante do português articule tal vogal, 
no início do aprendizado. Mais uma vez isso significa acrescentar uma sílaba aos dois primeiros verbos.

Enfim, no Quadro 17 os verbos regulares no tempo passado watched e bathed foram articulados com a vogal epentética pelo falante do português, entre os dois fonemas consonantais finais.

Para o verbo regular waited podemos notar que há uma produção muito próxima do falante nativo, entretanto a articulação final é realizada tanto com a seqüência / -Id / como com / -əd /.

Quadro 17: Contraste de Verbos Regulares do Inglês

\begin{tabular}{|c|c|}
\hline \multicolumn{2}{|c|}{ Contraste de produções de vocábulos ingleses } \\
\hline Falante nativo & Falante do português \\
\hline watched / wa:tst / & 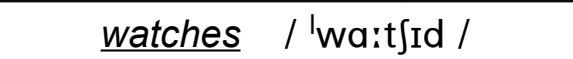 \\
\hline bathed / berðd / & bathed / 'berðıd / \\
\hline waited /'weitid / & waited / 'weitid / ou / 'weitəd / \\
\hline
\end{tabular}

\subsubsection{Alofonia Diferente}

Os fonemas ingleses africados alveolopalatais / t $/ \mathrm{e} / \mathrm{d} 3 /$, não fazem parte do inventário fonológico consonantal do Português (STEINBERG, 1985 e 2006; Cristófaro-Silva, 2002 e 2003).

Por outro lado, se os fonemas portugueses oclusivos alveolares / t / e / d / forem seguidos da vogal -i (oral ou nasal), ou mais raramente e, 
terão a articulação dos alofones [t $\mathrm{t}]$ e $[\mathrm{d} 3]$ respectivamente ${ }^{20}$. Vejamos os exemplos das possibilidades de articulação dos vocábulos do português nos Quadros 18 e 19.

Quadro 18: Alofones de / t /

\begin{tabular}{|c|c|c|c|}
\hline Português & Possibilidade 1 & Possibilidade 2 & Inglês \\
\hline pratica & [ praltstkə ] & [ praltikə ] & (he/she) practices \\
\hline tinta & [ 't finte ] & [ 'tintə ] & paint / ink \\
\hline poste & {$\left[\operatorname{pos}^{\prime} t \int \mathrm{I}\right]$} & [ pos'ti ] & (lamp) post \\
\hline
\end{tabular}

Quadro 19: Alofones de / d /

\begin{tabular}{|c|c|c|c|}
\hline Português & Possibilidade 1 & Possibilidade 2 & Inglês \\
\hline adivinha & [ aldzivinə ] & [ aldivinə ] & guess \\
\hline dica & [ 'dzIkə ] & [ 'dikə ] & tip \\
\hline pudim & [ pu'dzin ] & [ pu'diN ] & flan \\
\hline
\end{tabular}

Um outro aspecto sobre alofonia da língua inglesa pode alterar a articulação de uma seqüência de fonemas entre dois vocábulos. Por exemplo, num determinado momento da fala, os falantes nativos podem articular os fonemas consonantais alveolares $/ \mathrm{t} /, / \mathrm{d} /, / \mathrm{s} / \mathrm{e} / \mathrm{z} /$, diferentemente se forem seguidos por um vocábulo iniciado pelo fonema palatal / j / (Quadro 20).

\footnotetext{
${ }^{20}$ Sobre esse aspecto Cristófaro-Silva (2002) ainda acrescenta que neste contexto fonético há a possibilidade do falante do português de alguns dialetos de Belo Horizonte utilizarem outras vogais ou mesmo do [ $t$ ] e do [ d ] seguidos pelas consoantes -1 e -r, resultando na produção de [ t $\int$ ] e [ d3 ]. Para esta cidade, podemos exemplificar com as os vocábulos alta e calda, as quais costumam ser produzidas com as africadas, tendo como produção [ 'awtse ] e [ 'kawdze ]. Como iremos tratar de descrever e analisar as possibilidades de produzir os fonemas / t / e / d / em vocábulos pelos falantes do português, da cidade de São Paulo, possivelmente o aspecto acima descrito pelos falantes de Belo Horizonte, não irão ter nenhuma ocorrência em nossa amostra. Assim, os exemplos de transcrição fonética que acabamos de ilustrar servem apenas como contribuição para que consigamos alcançar nosso objetivo de explicar as possíveis dificuldades que o falante do português tem ao aprender inglês como língua estrangeira, no contexto em que ocorrem os fonemas descritos acima.
} 
Há uma grande probabilidade da união desses fonemas resultar em $/ \mathrm{t} \int /, / \mathrm{d}_{3} /$, $/ \int$ lou $/ 3 /$.

Quadro 20: Processo de Palatalização - falantes do inglês

\begin{tabular}{|c|c|c|}
\hline Exemplos & $\begin{array}{c}\text { União dos } \\
\text { fonemas }\end{array}$ & Resultado \\
\hline forget_your passport & $/ \mathrm{t} /+/ \mathrm{j} /$ & $\rightarrow / \mathrm{t} /$ \\
\hline need_your jacket & $/ \mathrm{d} /+/ \mathrm{j} /$ & $\rightarrow / \mathrm{d} 3 /$ \\
\hline miss_your train & $/ \mathrm{s} /+/ \mathrm{j} /$ & $\rightarrow / \mathrm{J} /$ \\
\hline lose_your camera & $/ \mathrm{z} /+/ \mathrm{j} /$ & $\rightarrow / 3 /$ \\
\hline \multicolumn{2}{|r|}{ (Exemplos adaptados de: Hewings \& GoLDSTEIN, 2000, p.83) } \\
\hline
\end{tabular}

Esse contexto ocorre provavelmente na fala rápida, fluente, principalmente com os fonemas oclusivos alveolares / t/ e / d / mais do que com / s / e / z /. Esse processo é chamado de 'palatalização', tanto em português como em inglês. Os autores Hewings \& GoldsteIn (2000, p.83-84) acrescentam ainda que durante o processo de palatalização, a sentença 'What's your name', pode parecer muito próxima de 'Watch your name', por exemplo.

Devemos comentar ainda um outro aspecto pertencente aos falantes da região metropolitana de São Paulo, com relação à articulação dos vocábulos portugueses que possuem a letra -I no final da sílaba.

Esse fonema no início do aprendizado da língua inglesa passa pelo processo de 'vocalização'. Todos os vocábulos ingleses ou portugueses com essa letra em final de sílaba, terão sua produção oral vocalizada pelo falante do 
protuguês, ou seja, o falante substituirá o - I final pelos fonemas / - w / ou / - $\mathrm{o}^{\mathrm{w}}$

I (CRistófaro-Silva \& Oliveira, 2001; Cristófaro-Silva \& Martins, 2002).

Se isso for aplicado no momento da produção dos vocábulos ingleses, o significado poderá ser alterado uma vez que a produção e o sentido do vocábulo irão mudar, pois foi adicionada uma vogal à última sílaba.

O contraste do vocábulo inglês fill, produzido pelos falantes do inglês e do português, demonstrado no Quadro 21, apresenta o fonema / -l/ final, o qual deveria ser sempre articulado como um fonema lateral velarizado [ 4 ], ou seja, um fonema consonantal. Porém, o falante do português da cidade de São Paulo utiliza-se do processo de vocalização, tal qual como o faz para articular as sílabas finais dos vocábulos portugueses com -I, substituindo então, o / - I / final por / -w /.

No caso deste vocábulo, durante um diálogo, pode ser que o falante nativo do inglês primeiramente entenda few $-\left[\mathrm{fI}^{\mathrm{w}}\right]$ ao invés de fill - [ $\left.\mathrm{fI}^{\dagger}\right]$. Porém, para compreender o que o falante não-nativo quis dizer, precisará prestar atenção ao contexto em que o vocábulo foi inserido e sua respectiva colocação na sentença, a qual demonstrará sua categoria gramatical, e assim poderá deduzir o que o falante do português "tentou dizer". Essa substituição de fonemas poderá gerar um vocábulo inexistente na língua inglesa. 
Quadro 21: Vocábulo Inglês 'fill' - falantes do inglês e do português

\begin{tabular}{|c|c|}
\hline \multicolumn{2}{|c|}{ Vocábulo inglês 'fill' } \\
\hline Falante do inglês & Falante do português \\
\hline$\underline{\text { fill } / \mathrm{fIl} /}$ & $\underline{\text { fill } / \mathrm{fI}^{\mathrm{w}} /}$ \\
\hline
\end{tabular}

\subsubsection{Proximidade Fonética}

Sabemos que os fonemas fricativos interdentais ingleses $/ \theta /$

e / ð / não existem no inventário fonético-fonológico da língua portuguesa. Por isso esses fonemas, no início da aprendizagem da língua inglesa, poderão trazer ao aluno dificuldades para pronunciá-los.

Para efetivar a sua comunicação na língua-alvo o estudante emitirá fonemas semelhantes que está acostumado a ouvir e a produzir, tal qual os fonemas surdos / $/$, / s /, /f / e os sonoros $/ \mathrm{d} /, / \mathrm{z} /, / \mathrm{v} /$, respectivamente para $/ \theta / \mathrm{e} / \partial /$, tal como afirmam O‘Connor (1980), OdLIN (1989), e ROACH (1983).

O vocábulo thin, foi produzido pelo falante do português com o fonema oclusivo alveolar surdo / t/ (Quadro 22). Podemos definir essa articulação inadequada como uma interferência ou transferência negativa, a qual pode ser explicada pela própria ortografia do th no vocábulo, resultando simplesmente na articulação da letra t. Esse caso é um fator de interferência, uma vez que no português a letra $\mathbf{h}$ não ocorre nessa mesma seqüência. 
Para podermos explicar o contexto fonológico do th no vocábulo thin, pelos falantes do português, temos que concordar com os autores O'CONNOR (1980), ROACH (1983), e OdLIN (1989), os quais afirmam que há uma proximidade fonológica dos fonemas interdentais da língua inglesa aos fonemas que pertencem ao inventário fonológico da língua portuguesa. $\mathrm{O}$ fonema inglês fricativo interdental surdo $/ \theta$ / pode ser interpreteado e realizado pelo falante do português como fonema oclusivo alveolar sonoro / t /, ou como fricativo alveolar surdo / s /, ou ainda como fricativo labiodental sonoro / $\mathrm{f} /$.

Observamos que o vocábulo this traz as possibilidades de produção do fonema inglês fricativo interdental sonoro / ð / (Quadro 22). Esse pode ser realizado pelo falante do português como um fonema oclusivo alveolar sonoro / d /, ou com um fricativo alveolar sonoro / $\mathrm{z} /$, ou ainda com um fricativo labiodental sonoro / v /. 
Quadro 22: Vocábulo Inglês 'thin' e 'this' - falantes do inglês e do português

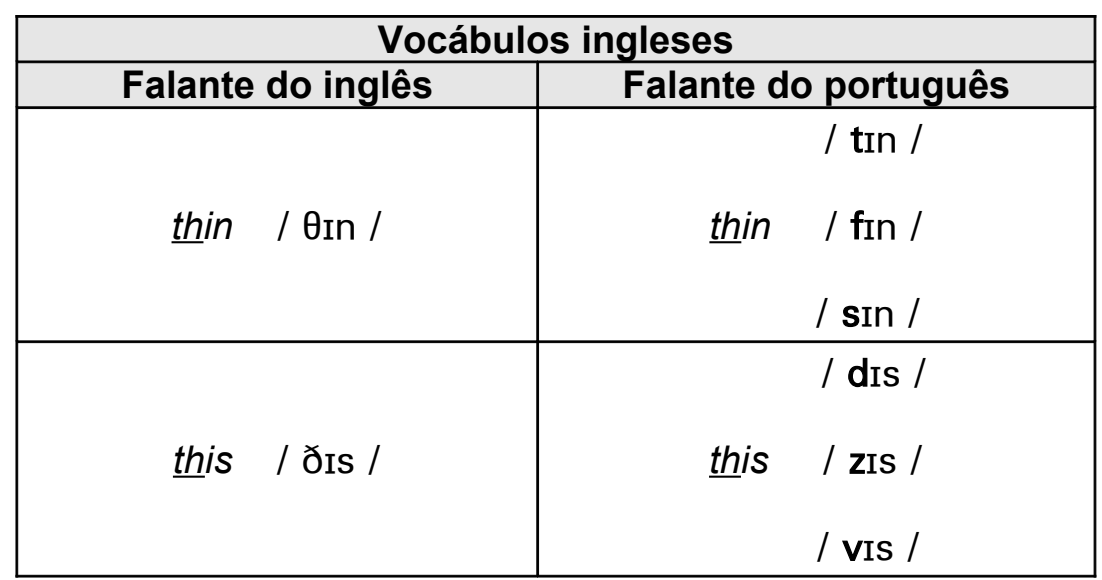

Um outro caso de proximidade fonética seria o fonema inglês fricativo glotal surdo / h /. Há duas possibilidades de produção oral do falante do português para esse fonema, uma delas seria a transferência da letra $\mathbf{h}$ do português que não tem articulação. A outra seria a troca desse pelo fonema vibrante alveolar sonoro / r /. Ambos os casos geraria um vocábulo de significado diferente ou não existente no idioma inglês.

O falante do português irá utilizar um fonema existente na sua língua materna para produzir um fonema da língua-alvo, que tenha o ponto de articulação muito próximo do fonema da língua estrangeira, provavelmente devido ao fato de não tê-lo reconhecido auditivamente como um fonema pertencente apenas ao inventário fonológico da língua-alvo. 
Especificamente para esse caso, ele o substituirá pelos alofones sonoros de / $r /,[r]$ ou $[x]$. Para superar esse erro o aluno terá que estudar as diferenças fonético-fonológicas existentes em ambas as línguas e treiná-las para adquirir uma articulação inteligível.

Quadro 23: Vocábulo Inglês 'house' - falantes do inglês e do português

\begin{tabular}{|c|c|}
\hline \multicolumn{2}{|c|}{ Vocábulo inglês 'house' } \\
\hline Falante do inglês & Falante do português \\
\hline house / haus / & house / raus / \\
/ xaus / \\
\hline
\end{tabular}

Como foi abordado, ao aprender a língua inglesa o falante do português encontra muitas dificuldades ao articular os fonemas consonantais elencados nos Quadros 1 a 23, os quais geram erros, ou por 'interferências' ou por 'transferências negativas'.

As dificuldades fonéticas e fonológicas apresentadas no Quadro 24 resume os tipos de erros que o falante adulto do português comete ao aprender inglês. 
Quadro 24: Resumo das Dificuldades de Produção

\begin{tabular}{|c|c|c|c|}
\hline $\begin{array}{l}\text { Interferências da } \\
\text { Língua Materna }\end{array}$ & \multicolumn{2}{|c|}{$\begin{array}{l}\text { Descrição de casos que } \\
\text { trazem dificuldades de } \\
\text { produção }\end{array}$} & Tipos de Erros \\
\hline \multirow{6}{*}{$\begin{array}{l}\text { Particularidades } \\
\text { fonológicas }\end{array}$} & \multirow{3}{*}{$\begin{array}{l}\text { Plural de } \\
\text { substantivos ou } 3^{a} \\
\text { pessoa do singular } \\
\text { ou caso genitivo }\end{array}$} & $-s$ & Acréscimo de sílaba / ə / ou / I / \\
\hline & & $-\mathbf{z}$ & $\begin{array}{l}\text { Acréscimo de sílaba / ə / ou / I / } \\
\text { Ensurdecimento da consoante final / s / }\end{array}$ \\
\hline & & $-\mathrm{IZ}$ & Ensurdecimento da consoante final / s / \\
\hline & \multirow{3}{*}{$\begin{array}{l}\text { Passado dos verbos } \\
\text { regulares }(-\mathrm{ed})\end{array}$} & $-t$ & $\begin{array}{l}\text { Acréscimo de silaba / ə / ou / I / } \\
\text { Sonorização da consoante final / d / }\end{array}$ \\
\hline & & $-d$ & Acréscimo de silaba / ə / ou / I / \\
\hline & & -Id & --- \\
\hline \multirow{5}{*}{$\begin{array}{l}\text { Alofonia } \\
\text { diferente }\end{array}$} & \multirow{2}{*}{ Oclusivas alveolares } & $t+j$ & Africação / ts / \\
\hline & & $d+j$ & Africação / dz / \\
\hline & \multirow{2}{*}{ Fricativas alveolares } & $s+j$ & Palatização / S / \\
\hline & & $z+j$ & Palatização / 3 / \\
\hline & Lateral & 4 & $\begin{array}{l}\text { Vocalização / -w / e / -ow / } \\
\text { ou / - } / \text { / e / - ow / }\end{array}$ \\
\hline \multirow{3}{*}{$\begin{array}{l}\text { Proximidade } \\
\text { fonética }\end{array}$} & \multirow{2}{*}{$\begin{array}{l}\text { Fonemas } \\
\text { interdentais }\end{array}$} & $\theta$ & Substituição desvozeada / t /, / s /, / f / \\
\hline & & б & Substituição vozeada / d /, / z /, / v / \\
\hline & Glotal desvozeada & h & Vibratização / r / \\
\hline
\end{tabular}

Para que a produção na língua-alvo atinja um nível de proximidade maior com a do falante nativo, LADO (1957) afirma que é necessário que o falante não-nativo desenvolva sua percepção auditiva em reconhecer as diferenças entre os fonemas e treiná-las até conseguir pronunciá-las. Esse aspecto também pode ser identificado em outros contextos fonéticos e fonológicos já citados. 
Portanto, nessa pesquisa temos como hipótese observar se os estudantes do curso de Tradutor de uma universidade privada da cidade de São Paulo:

a) Produzem durante a gravação da leitura oral de um texto sem treino, os fonemas e seus respectivos padrões silábicos finais do inglês adequadamente;

b) Após estimulação em sala de aula e treino do texto, a quantidade de produções inadequadas relacionadas aos padrões silábicos finais sofrem alguma alteração.

\subsubsection{O Ensino, a Fonologia e a Ortografia}

Do ponto de vista pedagógico, o professor de língua inglesa como segunda língua deve conhecer a língua materna do estudante e elencar as prováveis dificuldades de produção das consoantes finais dos vocábulos ingleses relacionados aos padrões silábicos, para que ele possa ajudar o estudante a alcançar uma articulação mais próxima do falante nativo.

Ao compararmos os padrões silábicos consonantais finais das sílabas inglesa e portuguesa podemos supor que o estudante, possivelmente produzirá uma sílaba a mais ao final dos vocábulos ingleses, sempre que houver um fonema consonantal final. Isso irá ocorrer pelo fato de que em português são raras as sílabas que terminam num fonema consonantal, conforme afirma STEINBERg (1985 e 2006). 
Abordado por autores, tais como CRISTÓfaro-SiLva (2002); Schumaker, White \& Zanettini (2002), esse aspecto nos mostra que o falante do português, aprendiz da língua inglesa, pode produzir uma vogal epentética, um fonema / -I / ou um schwa / -ə /, ao final das sílabas inglesas, pois ele buscará este apoio para produzir os vocábulos. Por outro lado, esse aspecto traz à tona um problema ainda maior que é a formação de vocábulos que não se encaixam no contexto ou mesmo a sua inexistência na língua-alvo.

Como exemplo do aspecto descrito acima, podemos afirmar que durante o início do aprendizado do inglês pelos falantes do português brasileiro, há o acréscimo da vogal epentética, que por sua vez adiciona uma sílaba aos vocábulos ingleses que terminam em fonemas consonantais, formando um vocábulo que não existe na língua-alvo: / 'terki / para take $=/$ terk /. Ou ainda, um vocábulo inglês possível, mas que não se encaixe ao contexto: / sæ引ks / sanks ao invés de produzir o vocábulo / Өæうks / thanks, que nesse caso é uma substituição de fonema da língua materna, pois o fonema que representa o 'th' surdo do inglês não possui correspondente na língua portuguesa.

Muitas dessas 'interferências' ou 'transferências negativas' ocorrem na produção oral pelo fato dos vocábulos terem a mesma grafia em ambas as línguas. Por isso sabemos que poderá gerar sentenças sem sentido, uma vez que têm significados diferentes (ScHüтz, 2004b).

Sabemos que os fonemas não são letras, como diz O'ConnoR (1980, p. 7) "letters are written, sounds are spoken", assim temos que mostrar e 
explicar ao estudante que conhecer o alfabeto fonológico irá facilitar seu entendimento durante o ensino-aprendizagem da língua inglesa.

Para tanto vale afirmar aos alunos que a grafia pode lembrá-los do fonema, mas nem sempre haverá letra e fonema correspondentes. Seria muito conveniente que letras e fonemas fossem idênticos, isso facilitaria (e muito!) o entendimento fonológico do estudante.

Sobre esse aspecto LADo (1957, p. 25) afirma que "Os fonemas são unidades de som que existem em todas as línguas que conhecemos, não importando se já tenham sido escritos ou não". Então, se os sistemas de escrita das línguas representam sons, isso faz com que os alunos se atrapalhem durante a leitura de vocábulos ou frases no início do aprendizado. Pois eles utilizarão o inventário fonológico de sua língua materna para articular os fonemas da língua estrangeira. Além do mais, se o alfabeto fonológico das línguas envolvidas for semelhante, os estudantes poderão produzir erroneamente os vocábulos da língua-alvo devido às influências dessa transferência.

Para podermos esclarecer a possibilidade da interferência da ortografia na articulação de fonemas ou seqüências de fonemas, precisamos ilustrar o problema de modo que o estudante entenda a incoerência da ortografia da língua inglesa.

Observando o caso da letra $\mathbf{p}$ - nos seguintes vocábulos ingleses pen e phone verificamos que na escrita temos a ocorrência da letra, mas na pronúncia temos respectivamente / pen / e / fown /, o que demonstra que a letra $\mathbf{p}$ seguida do $\mathbf{h}$, do segundo vocábulo deve ser articulada como / f- / e 
não como / p- /. Assim, o falante do português ao aprender inglês poderá articular essa letra inadequadamente, ao invés de produzi-la como deveria, uma vez que a seqüência em inglês ph devem ser articuladas como a letra $\mathbf{f}$ inicial (LADO, 1957). Isto significa dizer que se o aluno desconhece que no vocábulo phone a letra $\mathbf{p}$ deva ser produzida juntamente com o $\mathbf{h}$, formando o som inicial de / f- /, resultará num outro tipo de interferência. Não há como dizer que houve influência da língua materna nesse caso, mas sim que houve a falta de conhecimento fonológico prévio sobre o aspecto descrito acima. Portanto, é importante lembrar que o professor deve ficar atento e verificar se o aluno presta atenção na produção dos fonemas e suas respectivas seqüências de sons para perceber que os fonemas da língua estrangeira também possuem aspectos fonológicos diferentes (DaLton \& SeidLhofer, 1994).

Os Quadros 25 e 26 mostram a possível confusão que o estudante da língua inglesa pode cometer ao articular um vocábulo que possui a mesma grafia em ambas as línguas.

O vocábulo da língua inglesa come (verbo vir - presente do indicativo) ilustra a comparação do referido vocábulo português com o come (do verbo comer - presente do indicativo $-3^{a}$ pessoa do singular).

Quadro 25: Verbo Inglês 'to come'

\begin{tabular}{|l|l|}
\hline \multicolumn{2}{|c|}{ Vocábulo Inglês 'come' } \\
\hline Falante nativo & Falante do português \\
\hline$\underline{\text { come }} / \mathrm{k} \wedge \mathrm{m} /$ & $\underline{\text { come }}$ [ 'kãmI ] ou [ 'komI ] \\
\hline
\end{tabular}


Quadro 26: Verbo Português 'comer'

\begin{tabular}{|c|}
\hline Vocábulo Português 'come' \\
\hline Falante nativo \\
\hline come [ ['komi ] \\
\hline
\end{tabular}

O Quadro 25 demonstra que o vocábulo monossilábico da língua inglesa come passa a ser dissílabo quando produzido erroneamente pelo falante do português e também fica sem sentido uma vez que tal vocábulo não existe na língua inglesa, esse problema ou dificuldade deverá ser uma preocupação do professor ao ensinar o idioma inglês como língua estrangeira.

Nesse sentido KENWORTHY (1990) afirma que desde o início do aprendizado o aluno deverá ser incentivado a ouvir e articular os fonemas, e seus respectivos e diferentes padrões silábicos das línguas envolvidas no processo de aquisição de uma língua estrangeira.

Assim, temos a hipótese de que para o estudante atingir uma pronúncia inteligível, é fundamental que ele deva habituar-se a ouvir e a produzir e a treinar oralmente os vocábulos da língua estrangeira, para que desta forma obtenha a articulação mais próxima possível do falante nativo. 
Objetivos 
- Objetivo Geral

O objetivo geral desta pesquisa é: analisar a produção das consoantes inglesas em final de vocábulo por falantes brasileiros, estudantes do curso de Tradutor numa universidade privada da cidade de São Paulo.

\section{- Objetivos Específicos}

a) Descrever a ocorrência de erros bem como analisar as categorias de erros das consoantes inglesas em final de vocábulo nos padrões silábicos VC e CVC, por falantes brasileiros, estudantes do curso de Tradutor de uma universidade privada da cidade de São Paulo, em gravação sem treino;

b) Descrever a ocorrência de erros bem como analisar as categorias de erros das consoantes inglesas em final de vocábulo nos padrões silábicos VC e CVC, por falantes brasileiros, estudantes do curso de Tradutor de uma universidade privada da cidade de São Paulo, em gravação após treino;

c) Estudar as comparações entre a $1^{a}$ coleta e a $2^{a}$ coleta, com vistas a uma contribuição ao processo de ensino/aprendizagem do inglês como língua estrangeira;

d) Verificar as possíveis correlações entre o questionário, as categorias de erros e o desempenho dos alunos. 
MÉTOdo 


\section{Caracterização da Pesquisa}

Esta é uma pesquisa observacional. A todos os sujeitos e professores envolvidos, bem como a instituição particular, foi-lhes garantido o sigilo e a privacidade dos dados coletados tanto das respostas pessoais como das gravações. Todos os sujeitos desta pesquisa eram alunos do curso de Tradutor do segundo ano letivo de uma instituição privada de ensino superior da cidade de São Paulo.

\subsection{Sujeitos}

Fizeram parte desta pesquisa 45 sujeitos matriculados no $4^{\circ}$ semestre do curso de Tradutor de uma universidade da cidade de São Paulo. Os dados de parte dos sujeitos (23) foram coletados em 2003 e os demais (22) em 2004.

Para participar da pesquisa os sujeitos precisavam estar matriculados na disciplina de Pronúncia da Língua Inglesa que tanto em 2003 e 2004 foi ministrada pela mesma professora.

O grupo composto pelos 45 sujeitos está descrito na Tabela 1.

Tabela 1: Distribuição dos sujeitos segundo idade e gênero

\begin{tabular}{|c|c|c|c|}
\hline \multirow{2}{*}{ Idade } & \multicolumn{3}{|c|}{ Sujeitos } \\
\cline { 2 - 4 } & $\begin{array}{c}\text { Gênero } \\
\text { feminino }\end{array}$ & $\begin{array}{c}\text { Gênero } \\
\text { masculino }\end{array}$ & Total de sujeitos \\
\hline de 19 a 41 & 12 & 33 & 45 \\
\hline
\end{tabular}




\subsection{Material}

O material utilizado para a viabilização dessa pesquisa foi constituído basicamente de um único texto, cujo autor e título são desconhecidos, vide o Anexo A. No Anexo B há uma tabela com a transcrição de cada um dos vocábulos do texto. A escolha do referido texto pela pesquisadora, se deu devido ao fato deste ser uma lista de compras com ritmo, rimas e musicalidade. É autêntico, por isso pode ser utilizado com tranqüilidade nas aulas de pronúncia da língua inglesa (HAVERSON, 1991).

Um ambiente próprio para a gravação do texto, sem ruídos, e o equipamento da 'Lab System', do laboratório de línguas da universidade, foi utilizado para as duas coletas de dados dos sujeitos.

Foi, também, aplicado um questionário para traçar o perfil sócioeconômico dos sujeitos envolvidos para que pudessem ser contrastados com os lingüísticos. O questionário encontra-se no Anexo D. As questões 16, 18, 20, 22, 23 e 24 tiveram mais de uma alternativa assinalada por alguns sujeitos, por isso há mais de 45 respostas dadas a tais questões.

\subsection{Procedimentos}

\subsubsection{Seleção dos sujeitos}

Inicialmente foi discutida com a coordenadora do referido curso a possibilidade de execução da pesquisa. Assim, foi apresentado o objetivo da pesquisa que envolve a verificação das dificuldades fonético-fonológicas de produção das consoantes inglesas finais, dos estudantes durante a aquisição- 
aprendizagem do inglês como língua estrangeira, no ensino superior. Nesse contato foram esclarecidas as dúvidas referentes ao projeto de pesquisa e a sua execução.

Após a autorização da coordenação, as turmas do $4^{\circ}$ semestre do curso foram convidadas a participar da pesquisa e os alunos tiveram a oportunidade de ter esclarecido os procedimentos para a realização da coleta de dados. No mesmo momento os sujeitos responderam ao questionário (vide Anexo D) e tiveram o sigilo dos dados garantido pela pesquisadora.

\subsubsection{Coleta dos dados}

A professora responsável pela disciplina "Pronúncia da Língua Inglesa", foi convidada pela pesquisadora e pela coordenação do curso para auxiliar na coleta de dados, tanto em 2003 como em 2004.

Para que pudéssemos comparar o desenvolvimento ou aquisição e aprimoramento fonológico e fonético dos alunos na disciplina de "Pronúncia da Língua Inglesa" todos os sujeitos do grupo realizaram as duas gravações no laboratório de línguas da universidade, em fitas cassete individuais. A primeira delas ocorreu na segunda semana de agosto e a última foi realizada no final do mês de novembro.

Durante os quatro meses de aula, todos os alunos participaram das atividades planejadas para a disciplina que incluíam o treinamento da discriminação auditiva e de produção oral dos fonemas da língua inglesa. Em primeiro lugar foi apresentado aos alunos o alfabeto fonético internacional, de modo que começassem a se familiarizar com os fonemas e também com suas 
respectivas articulações. Iniciamos mostrando a representação gráfica e produção oral de cada som do inglês e em seguida o treino dos fonemas consonantais e fonemas vocálicos da língua inglesa.

Durante os meses de aulas sempre houve a preocupação em realizar a comparação dos fonemas semelhantes e diferentes de ambas as línguas (LADO, 1957), tanto nas aulas teóricas como nos treinos orais realizados em sala e no laboratório, tratando das diferenças e das interferências fonéticas e fonológicas da língua materna durante o aprendizado da língua inglesa. Mais ao final do curso houve também treino com os alunos que tratavam da entonação e do ritmo da língua estrangeira. No Anexo $\mathrm{F}$ pode ser visto o detalhamento do programa desenvolvido.

Para a coleta específica para a presente pesquisa, o texto da lista de compras foi entregue aos sujeitos recebendo as seguintes orientações para a gravação:

a) Na primeira gravação, no mês de agosto, a professora, que auxiliou nos procedimentos da coleta de dados, orientou-os a ler a lista de compras, apenas uma vez silenciosamente, antes de efetuar a gravação. Ou seja, não houve treino do texto, sendo que os estudantes articularam os vocábulos da maneira que acharam que estaria correto.

b) Na segunda gravação do mesmo texto, em novembro, houve treino coletivo dos alunos com a professora, em sala de aula, uma semana antes de efetuar a gravação, enfatizando primeiramente as rimas e depois o ritmo frasal do texto. Nessa aula a professora leu linha por linha do texto e os 
alunos repetiram as frases por duas vezes em conjunto, sendo corrigido os erros de maneira geral. As instruções seguintes foram que os alunos realizassem treinos orais durante uma semana antes da leitura para a gravação.

Destacamos que tanto na primeira como na segunda coleta as gravações foram feitas individualmente, na presença da professora e do técnico de gravação. Vale lembrar que a professora utilizou as gravações para avaliar o desempenho de seus alunos, segundo os objetivos da disciplina ministrada. Esta atitude foi tomada por entender que os estudantes poderiam melhorar a partir dos comentários realizados pela professora sobre os tipos de erros cometidos durante a leitura do texto. Esta também foi uma alternativa para a professora verificar se os alunos possuíam dificuldades em articular quaisquer fonemas ou padrões silábicos semelhantes, de modo que ela pudesse auxiliá-los a superar essas dificuldades (Celce-Murcia \& Goodwin, 1991).

O texto lido e gravado pelos 45 sujeitos dessa pesquisa tem um total de 98 vocábulos, sendo que 77 terminam em fonema consonantal e os outros 21 em fonema vocálico (Anexo C). 


\subsection{Análise dos Dados}

\subsubsection{Padrões silábicos analisados}

Após a transcrição dos vocábulos do texto para cada sujeito, foram identificados aqueles produzidos de forma inadequada conforme pode ser observado no Anexo E.

Na Tabela 2 elencamos os padrões silábicos finais possíveis no texto utilizado para a coleta de dados. Notamos que os padrões nos quais os sujeitos apresentaram maior ocorrência de erros foram VC e CVC, os quais foram selecionados para a análise dos dados.

Consideraremos em nossa análise também os padrões silábicos mais complexos que têm VC e CVC como sílaba final, tais como os padrões silábicos (VC)VC, (VC)CVC, (CV)CVC e (CVCV)CVC. Dessa forma, iremos comentar em nossa análise dois grupos de padrões silábicos finais, o -VC e o CVC. Os critérios de separação de sílabas do inglês utilizados para as transcrições são de JonEs (1997). 
Tabela 2: Vocábulos Ingleses (-VC e -CVC) do texto

\begin{tabular}{|c|c|c|c|c|}
\hline \multicolumn{2}{|c|}{$\begin{array}{c}\text { Padrões Silábicos } \\
\text { Finais } \\
\text { do Inglês } \\
\text { (que serão analisados) }\end{array}$} & $\begin{array}{l}\text { Todas as Ocorrências } \\
\text { da Amostra sem Erro } \\
\text { (nas duas coletas) }\end{array}$ & $\begin{array}{c}\text { Ocorrências Inadequadas } \\
\text { da Amostra } \\
\text { (nas duas coletas) }\end{array}$ & Total \\
\hline \multirow{2}{*}{ VC } & VC & or & eight, of, oil & 4 \\
\hline & $(\mathrm{VC}) \mathrm{VC}$ & ---- & apples, olive & 2 \\
\hline \multirow{4}{*}{ CVC } & CVC & $\begin{array}{l}\text { could, cut, get, five, } \\
\text { four, going, John, juice, } \\
\text { much, not, share }\end{array}$ & $\begin{array}{l}\text { bag, book, cheese, cure, } \\
\text { Dutch, foil, half, ham, hot, } \\
\text { light, pot, pure, red, sole, } \\
\text { some, sure, ten, these, thick, } \\
\text { thin, whole, wine }\end{array}$ & 33 \\
\hline & (VC)CVC & ---- & useful & 1 \\
\hline & (CV)CVC & $\begin{array}{l}\text { cooking, measure, } \\
\text { peppers, shopping }\end{array}$ & kilos, pickles & 6 \\
\hline & (CVCV)CVC & bananas, tomatoes & potatoes & 3 \\
\hline
\end{tabular}

A partir das transcrições dos padrões silábicos do inglês proposto por JonEs (1997), alguns vocábulos foram eliminados da amostra analisada. Entre esses vocábulos estão os vocábulos sublinhados na Tabela 2, apples, pickles e half. Cada eliminação ocorreu em função de determinados aspectos abordados a seguir.

O vocábulo com o padrão $(\mathrm{CV}) \mathrm{CVC}$ registrado para pickles, teve que ser descartado por violar seu padrão silábico. Como justifica Jones (1997), a divisão das sílabas segue o princípio de que cada sílaba inglesa deve considerar 
o maior número de consoantes da esquerda para a direita, e a faz sempre representada por um ponto, como exemplificado abaixo:

$$
\text { pickles } \quad \rightarrow \quad / \text { 'pIk.lz / }
$$

A divisão silábica acima indica que há uma relação direta com o acréscimo de sufixos, pois sabemos que em inglês há uma ruptura na sílaba quando adicionamos qualquer afixo. No vocábulo pickles houve o acréscimo do -s, sufixo esse que representa o plural do substantivo, e observamos que o fonema /I/, neste caso, é um item silábico. Sabemos também que para se considerar uma consoante silábica, no momento da produção do vocábulo há a possibilidade de se acrescentar minimamente um fonema, o 'schwa', / ${ }^{\ominus} /$, antes dessa consoante. Esse aspecto ocorre com freqüência na fala fluente.

Há de se destacar aqui que as consoantes inglesas que formam uma sílaba por si só são denominadas de consoantes silábicas. São elas: / $\mathrm{m} \mathbf{n} \mathrm{n} / \mathrm{r} /$, sendo as realizadas com maior freqüência / I $\mathbf{n} /$. As consoantes silábicas ocorrem apenas em sílabas átonas e podem ser transcritas foneticamente com um sinal diacrítico (um pequeno traço) abaixo do fonema; [ l ], [ $\underline{r}],[\mathrm{m}],[\underline{\mathrm{n}}]$ e [ $\mathrm{\eta}$ ]. Por essa razão descartamos esse tipo de ocorrência por pertencer às características fonético-fonológicas da língua inglesa.

Em dicionários monolíngües da língua inglesa, tais como Longman Dictionary of English Language and Culture (1992) e Macmillan Essential Dictionary (2003), também encontramos a mesma divisão silábica para 
o vocábulo pickles, o que nos fez descartá-lo efetivamente. O mesmo decidimos para o vocábulo apples, com o padrão silábico (VC)VC, pois além da silabação diferente, há o acréscimo de um fonema vocálico / ə /, o 'schwa'. Vejamos as apresentações dos dicionários no Quadro 27.

Quadro 27: Transcrição dos Vocábulos 'pickles' e 'apples'

\begin{tabular}{|c|c|c|c|}
\hline Vocábulos & $\begin{array}{c}\text { Transcrição 1 } \\
\text { English Pronouncing } \\
\text { Dictionary (Jones, 1997) }\end{array}$ & $\begin{array}{c}\text { Transcrição 2 } \\
\text { Longman Dictionary of } \\
\text { English Language and } \\
\text { Culture }\end{array}$ & $\begin{array}{c}\text { Transcrição 3 } \\
\text { MacMillan } \\
\text { Essential Dictionary }\end{array}$ \\
\hline pick.les & / 'pIk.Iz / & / 'pIkəlz / & / 'pIk(ə)Iz / \\
\hline ap.ples & / 'æpp.lz / & / 'æpəlz / & / 'æp(ə)Iz / \\
\hline
\end{tabular}

O vocábulo half foi descartado pelo fato da professora ter trabalhado este em uma atividade em sala de aula. Tal fato pode ter influenciado a pronúncia do vocábulo o que poderia enviesar a análise.

Assim, a partir da seleção dos padrões silábicos finais ingleses que serão analisados, VC e CVC, elencaremos todos os vocábulos dessa amostra que foram produzidos com algum tipo de dificuldade pelo falante do português. Em outras palavras, a seleção dos padrões silábicos finais será feita segundo as categorias de erros já identificadas por nós como possíveis dificuldades em articular os fonemas consonantais finais que o falante do português tem ao aprender inglês, as quais foram explicadas nos itens das particularidades fonológicas e da alofonia diferente. 
Para que pudéssemos explicar alguns dos erros produzidos pelos sujeitos, realizaremos um levantamento que apresenta os 77 vocábulos, que terminaram em fonema consonantal com o vocábulo seguinte. Dessa forma teremos como justificar alguns desses erros ao considerarmos a língua materna dos sujeitos.

Portanto, a partir da eliminação dos vocábulos apples, half e pickles no Tabela 3 observamos as possibilidades de ocorrências dos padrões silábicos analisados na amostra de fala coletada.

Tabela 3: Possibilidades de Ocorrências na Amostra

\begin{tabular}{|c|c|}
\hline $\begin{array}{c}\text { Padrão } \\
\text { Silábico }\end{array}$ & $\begin{array}{c}\text { Possibilidades de } \\
\text { Ocorrências }\end{array}$ \\
\hline VC & 5 \\
\hline CVC & 42 \\
\hline
\end{tabular}

\subsubsection{A relação dos padrões silábicos (CVC e VC) com o vocábulo}

\section{seguinte}

Como já explicamos anteriormente, os vocábulos do texto foram divididos de acordo com o padrão silábico final, VC e CVC.

No Quadro 28 destacamos os vocábulos terminados em fonemas vocálicos com o propósito de podermos justificar as ocorrências inadequadas de nossa amostra. Esses vocábulos estavam presentes no texto logo após aqueles dos dois padrões silábicos, VC e CVC, analisados. 
Quadro 28: Fonemas Vocálicos Finais dos Vocábulos do Texto

\begin{tabular}{|c|l|}
\hline Fonema final & \multicolumn{1}{|c|}{ Vocábulos Ingleses } \\
\hline$/$-ər / & butter, Dover, flour, measure, paper \\
\hline$/$-ə / & a (weak form), me (weak form), the (weak form), to (weak form) \\
\hline$/$-eI / & a (strong form) \\
\hline / -i / & coffee, cookery, early, the (strong form/before vowel sounds), very \\
\hline / -i: / & me (strong form), the (strong form), three \\
\hline / -u: / & glue, to (strong form), too, two \\
\hline / -ju: / & few, new, you \\
\hline / -ou / & yellow \\
\hline
\end{tabular}

Da mesma forma, o Quadro 29 destaca os vocábulos terminados em fonema consonantal, que ocorreram depois dos vocábulos selecionados para serem analisados para essa pesquisa, segundo os padrões silábicos VC e CVC. 
Quadro 29: Fonemas Consonantais Finais dos Vocábulos do Texto

\begin{tabular}{|c|l|}
\hline $\begin{array}{c}\text { Fonema } \\
\text { final }\end{array}$ & \multicolumn{1}{|c|}{ Vocábulos } \\
\hline / -t / & cut, eight, first, get, hot, light, mixed, not, pot, white \\
\hline / -d / & and, could, pound, red \\
\hline / -k / & book, chunk, thick \\
\hline / -g / & bag \\
\hline / -f / & half, if \\
\hline / -v / & five, of, olive \\
\hline / -s / & it's, juice, plates, six, sorts, thanks \\
\hline / -z / & $\begin{array}{l}\text { apples, bananas, beans, cheese, kilos, kinds, pears, peppers, } \\
\text { pickles, please, potatoes, these, things, tins, tomatoes, tubes }\end{array}$ \\
\hline / -t / & bunch, Dutch, much \\
\hline / -d3 / & large, orange \\
\hline / -l / & foil, oil, sole, useful, whole \\
\hline / -r / & beer, cure, dear, four, or, pure, share, sure, you're \\
\hline / -m / & ham, some \\
\hline / -n / & brown, carton, corn, green, John, ten, thin, wine \\
\hline / -n / & cooking, going, shopping \\
\hline
\end{tabular}

Os vocábulos com os padrões silábicos VC e CVC do texto lido inadequadamente e gravado na $1^{\text {a }}$ coleta, pelos 45 sujeitos dessa pesquisa, totalizam 28 vocábulos, que estão elencados no Quadro 30. 
Quadro 30: Fonemas Consonantais Finais com Erro - $1^{\text {a }}$ coleta

\begin{tabular}{|c|l|}
\hline Fonema final & \multicolumn{1}{c|}{ Vocábulos } \\
\hline / -t / & eight, hot, light, pot, white \\
\hline / -d / & red \\
\hline / -k / & book, thick \\
\hline / -g / & bag \\
\hline / -v / & of, olive \\
\hline / -z / & cheese, kilos, potatoes \\
\hline / -t / / & Dutch \\
\hline$/$ - / & foil, oil, sole, useful, whole \\
\hline$/$-r / & cure, pure, sure \\
\hline / -m / & ham, some \\
\hline / -n / & ten, thin, wine \\
\hline
\end{tabular}

$\mathrm{Na} 2^{\mathrm{a}}$ coleta tivemos um total de 19 vocábulos, com os padrões silábicos VC e CVC, lidos inadequadamente. São os que se encontram elencados no Quadro 31. 
Quadro 31: Fonemas Consonantais Finais com Erro - $2^{\mathrm{a}}$ coleta

\begin{tabular}{|c|l|}
\hline $\begin{array}{c}\text { Fonema } \\
\text { final }\end{array}$ & \multicolumn{1}{|c|}{ Vocábulos } \\
\hline / -t / & eight, hot, light, white \\
\hline$/-\mathrm{k} /$ & book \\
\hline$/$-g / & bag \\
\hline$/-\mathrm{v} /$ & of, olive \\
\hline$/-\mathrm{z} /$ & these \\
\hline$/-\mathrm{I} /$ & foil, oil, sole, useful, whole \\
\hline / -m / & ham, some \\
\hline / -n / & ten, thin, wine \\
\hline
\end{tabular}

Outro aspecto interessante em se tratar é a relação entre os dois grupos de padrões silábicos escolhidos (VC e CVC) para serem analisados em nossa pesquisa conjuntamente com os vocábulos seguintes. Assim, iremos elencar essas seqüências, partindo do fonema final do vocábulo CVC ou VC com o fonema vocálico ou consonantal que inicia o seguinte.

a) / -t / : eight paper

pot of

hot coffee

light white

white wine

b) / -d / : red or

c) $/-\mathrm{k} /:$ book ...a

thick or

d) / -g /: bag of 
e) / -v /: of green

of mixed

of apples

of large

of hot

of corn

of bananas

of the

of light

of brown

of orange

of Dutch

olive oil

f) $/-\mathbf{z} /:$ cheese cut

potatoes ... eight

kilos of

these few

g) $/-\mathrm{t} \int /$ : Dutch cheese

h) / - / : foil ... some

oil and

sole ... five

useful new

whole Dover

i) / $-\mathrm{r} /$ : cure if

pure ... and

sure it's 
j) / -m / : ham to

some butter

some first

some olive

some beer

some pears

some ham

k) / -n /: ten red

thin ... thanks

wine ... a

É importante destacar que a amostra da presente pesquisa é composta por falantes do português brasileiro, que estão aprendendo o inglês como língua estrangeira e, que em sua aquisição do inglês normalmente realizam interferências fonético-fonológicas, as quais ocorrem mais destacadamente no início do aprendizado. Assim, descreveremos e analisaremos nossa amostra usando o termo categorias de erros para nos referimos às produções inadequadas encontradas.

Salientamos que dois dos vocábulos com os padrões silábicos escolhidos se repetiram mais de uma vez no texto, são eles: of (VC) e some (CVC). O vocábulo of aparece onze vezes no texto, enquanto some aparece seis. Mesmo assim, todas as articulações inadequadas dos sujeitos para os dois vocábulos em questão foram consideradas para a totalização do número de ocorrências. 


\subsubsection{Análise das Categorias de Erros}

A diferença entre as línguas nos remete a imaginar que os erros na produção dos vocábulos ingleses podem decorrer de vários fatores para os falantes do português. Conforme já descrevemos na introdução quando tratamos das particularidades fonológicas dentre tais fatores estão também a alofonia diferente, a proximidade fonética e a interferência da escrita. Ao abordarmos essas interferências que podem ocorrer durante a aquisição fonológica da língua inglesa, iremos identificá-las nas seguintes categorias de erros (fonéticos ou fonológicos):
a) 'adição ou acréscimo': de sílaba;
b) 'nasalização': dos fonemas nasais do inglês;
c) 'omissão ou apagamento': da consoante final do vocábulo;
d) 'substituição ou transferência': da língua materna;
e) 'vocalização': do -I pós-vocálico.

No Quadro 32 observamos as categorias de erros nos padrões silábicos dos vocábulos do texto lido pelos sujeitos, que foram considerados com erro do fonema consonantal final, independentemente do número dos sujeitos que cometeram tal erro, bem como do número de vezes em que o erro ocorreu. 
Quadro 32: Categorias de Erros, Padrões Silábicos VC e CVC e Vocábulos do Texto

\begin{tabular}{|c|c|c|c|c|c|}
\hline $\begin{array}{c}\text { Categorias } \\
\text { de Erros }\end{array}$ & $\begin{array}{l}\text { Padrões } \\
\text { Silábicos }\end{array}$ & $\begin{array}{l}\text { Vocábul } \\
0 \\
\text { Escrito }\end{array}$ & $\begin{array}{c}\text { Transcrição } \\
\text { Correta }\end{array}$ & $\begin{array}{l}\text { Produção } \\
\text { com Erro }\end{array}$ & $\begin{array}{l}\text { Ocorrência } \\
\text { nas Coletas }\end{array}$ \\
\hline \multirow{9}{*}{$\begin{array}{l}\text { Adição ou } \\
\text { Acréscimo }\end{array}$} & \multirow{2}{*}{ VC } & eight & eIt & eI'tI & 1 e 2 \\
\hline & & oil & oIl & כU & 1 \\
\hline & (VC)VC & olive & Ioliv & Iolivi & 1 e 2 \\
\hline & \multirow{16}{*}{ CVC } & bag & bæg & 'bægI & 1 e 2 \\
\hline & & book & buk & IbukI & 1 e 2 \\
\hline & & cheese & tfi:z & $\mathrm{t} t \int i: z I$ & 1 \\
\hline & & cure & kjur (AmE) - kjuər, kjo: $:^{r}(B r E)$ & 'kjurI & 1 \\
\hline & & hot & ha:t (AmE) - hot (BrE) & 'ha:tI & 1 e 2 \\
\hline & & light & laIt & 'laitI & $1 \mathrm{e} 2$ \\
\hline \multirow{10}{*}{$\begin{array}{l}\text { (Acréscimo de } \\
\text { um fonema } \\
\text { vocálico ou } \\
\text { consonantal ao } \\
\text { vocábulo, } \\
\text { durante sua } \\
\text { produção.) }\end{array}$} & & pot & pa:t (AmE) - pot (BrE) & Ipa:tI & 1 \\
\hline & & pure & 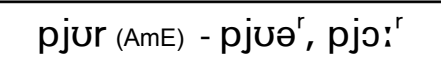 & IpjurI & 1 \\
\hline & & red & red & 'redi & 1 e 2 \\
\hline & & sole & SOUl (AmE) - SOUl (BrE) & IsoulI & $1 \mathrm{e} 2$ \\
\hline & & some & sım & IsımI & $1 \mathrm{e} 2$ \\
\hline & & sure & 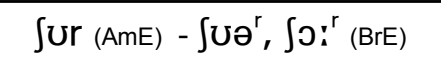 & ISUrI & 1 \\
\hline & & these & ði:z & lði:zi & 2 \\
\hline & & white & waIt & IwaItI & $1 \mathrm{e} 2$ \\
\hline & & whole & houl (AmE) - həul (BrE) & 'houlI & 1 e 2 \\
\hline & & wine & wain & I'wainI & 1 e 2 \\
\hline \multirow{3}{*}{\begin{tabular}{|c|} 
Nasalização \\
(Troca de um \\
fonema consonantal \\
nasal poss-vocáliloco \\
por uma vogal \\
nasal.)
\end{tabular}} & \multirow{3}{*}{ CVC } & ham & hæm & haN & $1 \mathrm{e} 2$ \\
\hline & & ten & ten & teiN & 1 e 2 \\
\hline & & thin & $\theta$ In & $\theta \mathrm{iN}$ & 1 e 2 \\
\hline \multirow{4}{*}{$\begin{array}{c}\text { Omissão ou } \\
\text { Apagamento } \\
\text { (Não há } \\
\text { produção de um } \\
\text { determinado } \\
\text { fonema.) }\end{array}$} & \multirow[b]{2}{*}{ CVC } & sole & SOUl (AmE) - SOUl (BrE) & sou & 1 \\
\hline & & whole & houl (AmE) - həul (BrE) & rou & 1 e 2 \\
\hline & (CV)CVC & kilos & 'ki:louz (AmE) - 'ki:ləuz & 'kilous & 1 \\
\hline & (CVCV)CVC & potatoes & $\begin{array}{c}\text { pəlteItouz (AmE) - pəlteit } \\
\text { əUZ (BrE) }\end{array}$ & tə'meitou_ & 1 \\
\hline
\end{tabular}




\begin{tabular}{|c|c|c|c|c|c|}
\hline $\begin{array}{c}\text { Categorias } \\
\text { de Erros }\end{array}$ & $\begin{array}{l}\text { Padrões } \\
\text { Silábicos }\end{array}$ & $\begin{array}{l}\text { Vocábulo } \\
\text { Escrito }\end{array}$ & $\begin{array}{l}\text { Transcrição } \\
\text { Correta }\end{array}$ & $\begin{array}{l}\text { Produção } \\
\text { com Erro }\end{array}$ & $\begin{array}{l}\text { Ocorrência } \\
\text { nas Coletas }\end{array}$ \\
\hline \multirow{4}{*}{$\begin{array}{c}\text { Substituição } \\
\text { ou } \\
\text { Transferên- } \\
\text { cia }\end{array}$} & VC & of & a:V (AmE) - DV (BrE) (strong & IDVI & 1 e 2 \\
\hline & \multirow{4}{*}{ CVC } & Dutch & $d \wedge t \int$ & $\mathrm{d} \wedge \mathrm{ks}$ & 1 e 2 \\
\hline & & thick & $\theta \mathrm{Ik}$ & tink & 1 \\
\hline & & thin & $\theta$ in & $\theta$ it & 1 \\
\hline \multirow{2}{*}{$\begin{array}{l}\text { (Troca de um } \\
\text { fonema por outro, } \\
\text { substituindo-oroor } \\
\text { um de sua li ingual } \\
\text { materna.) }\end{array}$} & & whole & houl (AmE) - həul (BrE) & 'houle & $1 \mathrm{e} 2$ \\
\hline & $(\mathrm{CV}) \mathrm{CVC}$ & kilos & 'ki:louz (AmE) - 'ki:ləuz (BrE) & 'ki:lous & 1 \\
\hline \multirow{5}{*}{$\begin{array}{c}\text { Vocalização } \\
\text { (A troca do 'p' pós- } \\
\text { vocálico pelo som } \\
\text { de uma vogal, } \\
\text { geralmente o', ou', } \\
\text { ou ' 'u'.) }\end{array}$} & VC & oil & oIl & $\mathrm{OI}^{\mathrm{w}}$ & $1 \mathrm{e} 2$ \\
\hline & \multirow{3}{*}{ CVC } & foil & forl & for ${ }^{w}$ & 1 e 2 \\
\hline & & sole & soul (AmE) - Səul (BrE) & 'souw & 1 \\
\hline & & whole & houl (AmE) - həul (BrE) & 'houw & 1 \\
\hline & (VC)CVC & useful & lju:sf'l, 'ju:sful & lju:sfow & $1 \mathrm{e} 2$ \\
\hline
\end{tabular}

A partir dos dados demonstrados no Quadro 33, montamos uma Tabela 4 para saber quantas vezes cada categoria de erros poderia ocorrer na amostra total, independentemente do vocábulo articulado inadequadamente pelos sujeitos.

Tabela 4: Número de Vezes que Cada Categoria de Erros Ocorreu na Amostra Total

\begin{tabular}{|l|c|c|c|c|}
\hline \multirow{2}{*}{ Categorias de Erros } & \multicolumn{2}{c|}{ VC } & \multicolumn{2}{c|}{ CVC } \\
\cline { 2 - 5 } & $\begin{array}{l}\text { por } \\
\text { sujeito }\end{array}$ & total & $\begin{array}{l}\text { por } \\
\text { sujeito }\end{array}$ & total \\
\hline Adição ou Acréscimo & 4 & 180 & 16 & 720 \\
\hline Nasalização & 0 & 0 & 3 & 135 \\
\hline Omissão ou Apagamento & 0 & 0 & 4 & 180 \\
\hline Substituição ou Transferência & 1 & 45 & 5 & 225 \\
\hline Vocalização & 1 & 45 & 4 & 180 \\
\hline
\end{tabular}




\subsection{Questionário}

A aplicação e a orientação sobre o preenchimento do questionário foram realizadas pela professora que coletou os dados. O mesmo foi entregue aos alunos em sala de aula, os quais foram respondidos e devolvidos em seguida ao seu término. Todos os estudantes que participaram da pesquisa preencheram o questionário.

As questões de número 18, 20, 22, 23 e 24 tiveram mais de uma resposta. Não houve instrução de que deveriam escolher apenas uma alternativa, deixamos os sujeitos livres para que pudessem melhor esclarecer seus pontos de vista e opiniões.

Assim, nas questões de 1 a 15 os dados levantados são descritivos, os quais foram tabulados para descrever os sujeitos dessa pesquisa.

A partir da questão 16 iniciamos com as perguntas relacionadas ao aprendizado de uma língua estrangeira. Houve questões sobre:

a) a intenção de estudar outra língua, além do inglês;

b) o por que da escolha do curso;

c) a motivação em estudar a língua inglesa;

d) os níveis de aquisição das habilidades lingüísticas;

e) o nível estrutural;

f) a importância do aprendizado da pronúncia. 
Quanto às questões de 23 a 26, nos fixamos em obter respostas que pudessem nos guiar na identificação do processo de aquisição fonológica da língua inglesa, sob a perspectiva dos estudantes. Tivemos a intenção de observar se com essas respostas talvez pudéssemos justificar as articulações inadequadas dos vocábulos da amostra.

\subsection{Método Estatístico}

Utilizamos o test $t$ de Student, com o software Statistic Package for the Sciences (SPSS), para analisar nossa amostra. Esse teste é um procedimento de análise de dados para testar a hipótese de que duas médias são iguais. Quanto maior for a diferença entre as médias, maior será o valor do $t$ calculado. Assim pudemos estabelecer se a diferença entre as médias possui significância estatística de 0,05.

Assim utilizamos o test $t$ para as amostras emparelhadas, pois a variável para cada sujeito é medida antes e depois de uma intervenção.

Para esse trabalho foram feitas duas coletas para cada padrão de linguagem utilizado e os resultados dos test $t$ são apresentados nos Anexos G, $\mathrm{H}$ e I. Além dos test $t$ também foram observados: o grau de significância, o desvio padrão, e o erro padrão das médias sempre considerando o Intervalo de confiança igual a $95 \%$.

Utilizamos o método estatístico também para fazermos uma análise considerando: as dificuldades elencadas pelos estudantes no questionário 
sobre ler, escrever, falar e ouvir. Conferir adiante no item '3.3. Questionário' as Figuras 2, 3, 4, 5, a esse respeito. 
Resultados 


\section{Análise dos Resultados}

No capítulo dos Resultados serão apresentadas as análises estatísticas descritivas e inferenciais da primeira e da segunda coletas e a comparação entre as mesmas, considerando os padrões silábicos, bem como das categorias de erros. A seguir são demonstrados os dados do questionário e sua relação com os erros nos padrões silábicos.

\subsection{Primeira Coleta}

A seguir demonstraremos os erros ou produções inadequadas realizadas pelos sujeitos nos padrões silábicos e das categorias de erros ocorridas na $1^{\text {a }}$ coleta.

\subsubsection{Padrões Silábicos}

Conforme descrito no método analisamos em conjunto os padrões silábicos do VC [VC; (VC)VC] e o do CVC [CVC; (CV)CVC; (VC)CVC; (CVCV)CVC], que constituíram os dois padrões silábicos analisados.

Quanto aos padrões silábicos VC e CVC, na primeira coleta, verificamos na Tabela 5 os dados descritivos das ocorrências de erros (Figura 2).

É importante destacarmos que na leitura feita pelos sujeitos há menos 
possibilidades de ocorrências do padrão silábico VC, conforme mostrado nas Tabelas 2 e 3 do capítulo Método.

A análise inferencial (test $t$ de Student pareado) mostrou diferenças significantes entre os padrões silábicos $(p<0,0001)$.

Tabela 5: Estatística Descritiva Proporcional das Ocorrências de Erros nos Padrões Silábicos ( $1^{\text {a }}$ coleta $)$

\begin{tabular}{|c|c|c|}
\hline $1^{\text {a }}$ Coleta & $\begin{array}{c}\text { Proporção de } \\
\text { Erros }\end{array}$ & $\begin{array}{c}\mathbf{N}^{\circ} \text { de } \\
\text { Sujeitos }\end{array}$ \\
\hline VC & $38 \%$ & 45 \\
\hline CVC & $15 \%$ & 45 \\
\hline
\end{tabular}

Figura 2: Porcentagem de Ocorrências de Erros dos Padrões Silábicos ( $\left(^{a}\right.$ coleta)

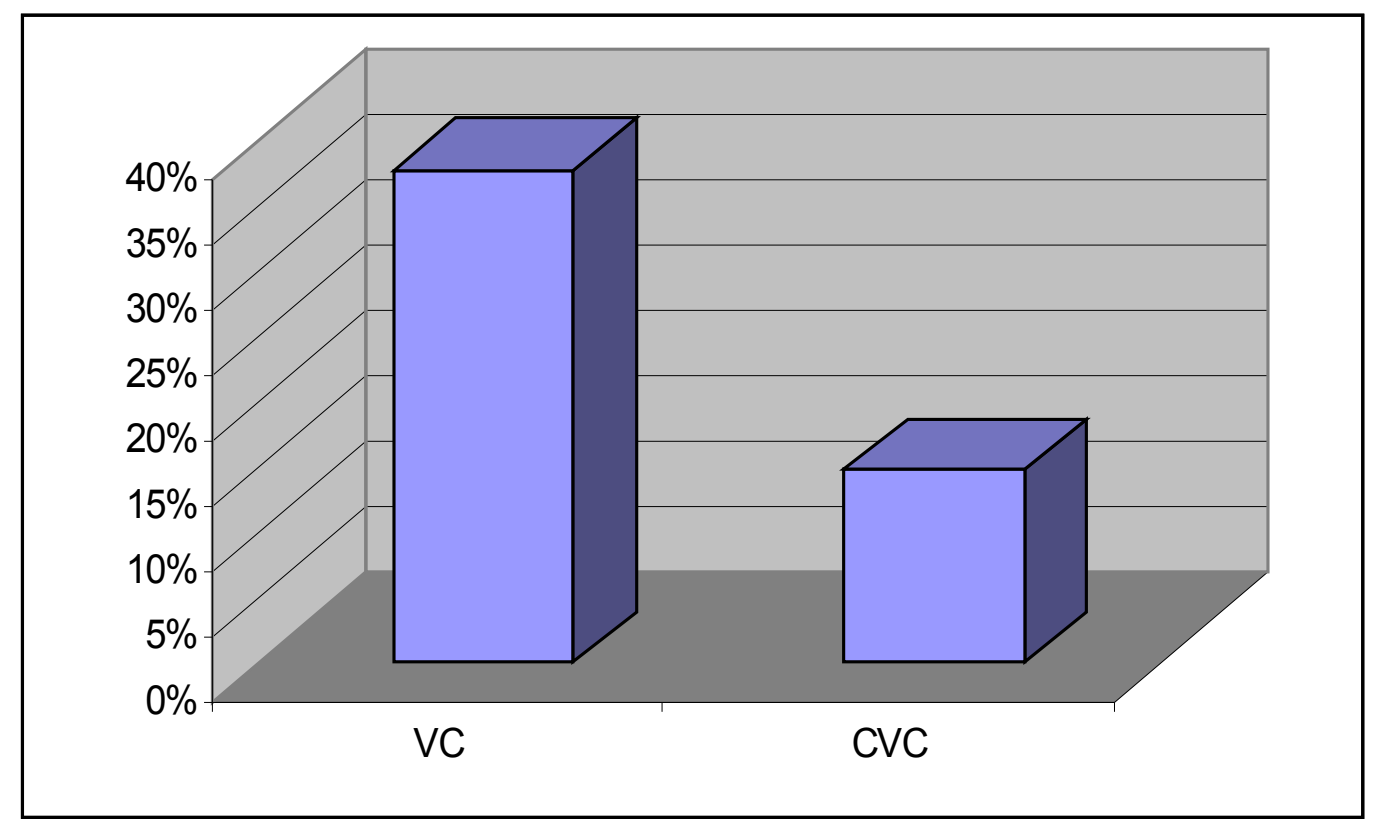

\subsubsection{Categorias de Erros}

Analisamos as categorias de erros que apresentamos no Método conforme indicado a seguir: 
a) 'adição ou acréscimo': de sílaba;

b) 'nasalização': dos fonemas nasais do inglês;

c) 'omissão ou apagamento': da consoante final do vocábulo;

d) 'substituição ou transferência': da língua materna;

e) 'vocalização': do -I pós-vocálico.

Assim, verificamos na Tabela 6 as ocorrências por vocábulo analisado classificadas de acordo com a respectiva categoria de erros. Na Figura 3 observamos a ocorrência das categorias de erros de acordo com os padrões silábicos no total de sujeitos que evidencia em VC somente o emprego da categoria de 'adição de ou acréscimo'. Já em CVC a maior freqüência foi de 'vocalização', 'nasalização', 'adição ou acréscimo', 'omissão ou apagamento' e por último 'substituição ou transferência'. 
Tabela 6: Ocorrência das Categorias de Erros nos Vocábulos - $1^{\text {a }}$ coleta

\begin{tabular}{|c|c|c|c|c|}
\hline \multirow{2}{*}{$\begin{array}{l}\text { Categorias } \\
\text { de Erros }\end{array}$} & \multicolumn{2}{|c|}{ VC } & \multicolumn{2}{|c|}{ CVC } \\
\hline & Vocábulo & Ocorrências & Vocábulo & Ocorrências \\
\hline \multirow{15}{*}{$\begin{array}{l}\text { Adição ou } \\
\text { Acréscimo }\end{array}$} & eight & 3 & bag & 6 \\
\hline & oil & 1 & book & 10 \\
\hline & olive & 2 & cheese & 1 \\
\hline & & & cure & 2 \\
\hline & & & hot & 19 \\
\hline & & & light & 4 \\
\hline & & & pot & 1 \\
\hline & & & pure & 2 \\
\hline & & & red & 5 \\
\hline & & & sole & 11 \\
\hline & & & some & 9 \\
\hline & & & sure & 2 \\
\hline & & & white & 9 \\
\hline & & & whole & 32 \\
\hline & & & wine & 15 \\
\hline \multirow{4}{*}{ Nasalização } & & & & \\
\hline & ----- & ---- & ham & 37 \\
\hline & & & ten & 3 \\
\hline & & & thin & 7 \\
\hline \multirow{4}{*}{$\begin{array}{l}\text { Omissão ou } \\
\text { Apagamento }\end{array}$} & 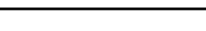 & $-\ldots$ & kilk & \\
\hline & & & potatoes & 1 \\
\hline & & & sole & 19 \\
\hline & & & whole & 4 \\
\hline \multirow{3}{*}{$\begin{array}{c}\text { Substituição } \\
\text { ou } \\
\text { Transferência }\end{array}$} & of & 40 & Dutch & 4 \\
\hline & & & kilos & 1 \\
\hline & & & thick & 3 \\
\hline \multirow{4}{*}{ Vocalização } & oil & 39 & foil & 40 \\
\hline & & & sole & 1 \\
\hline & & & useful & 38 \\
\hline & & & whole & 2 \\
\hline
\end{tabular}


Figura 3: Ocorrência das Categorias de Erros de acordo com os Padrões Silábicos no Total dos Sujeitos ( $1^{\text {a }}$ coleta $)$

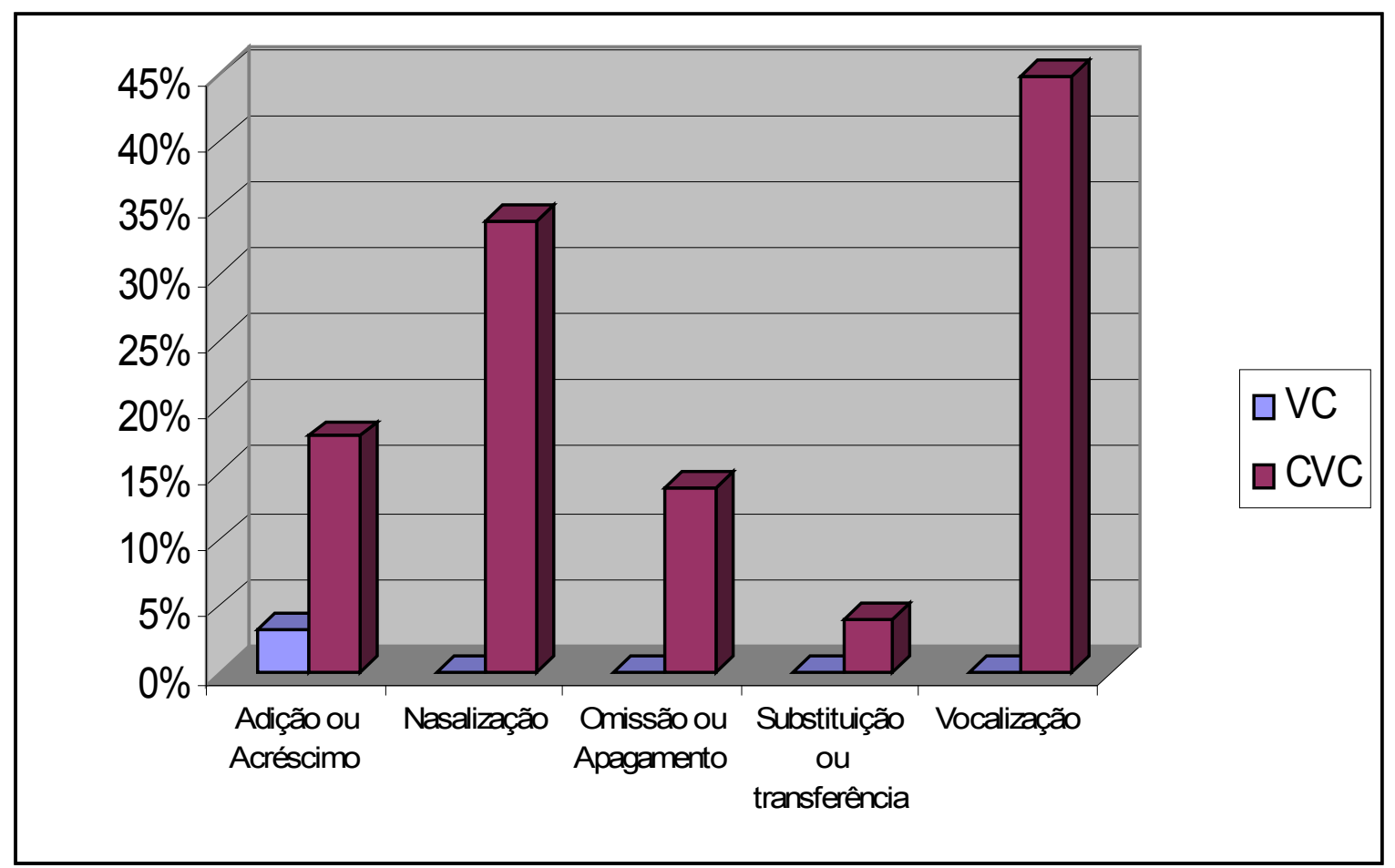

\subsection{Segunda Coleta}

\subsubsection{Padrões Silábicos}

Para a segunda coleta dos padrões silábicos VC e CVC observamos a estatística descritiva da Tabela 7. A análise inferencial (test $t$ de student pareado) mostrou diferencas significantes entre os padroes silábicos $(p<0,0001)$.

Como destacamos anteriormente, há menos possibilidades de ocorrências do padrão silábico VC, conforme mostrado nas Tabelas 2 e 3 do capítulo Método. 
Tabela 7: Estatística Descritiva das Ocorrências de Erros nos Padrões Silábicos $\left(2^{\mathrm{a}}\right.$ coleta)

\begin{tabular}{|c|c|c|}
\hline $\mathbf{2}^{\text {a }}$ Coleta & $\begin{array}{c}\text { Proporção } \\
\text { de Erros }\end{array}$ & $\begin{array}{c}\mathbf{N}^{\circ} \text { de } \\
\text { Sujeitos }\end{array}$ \\
\hline VC & $15,6 \%$ & 45 \\
\hline CVC & $6,5 \%$ & 45 \\
\hline
\end{tabular}

Figura 4: Porcentagem da Ocorrência de Erros de acordo com os Padrões Silábicos $\left(2^{\mathrm{a}}\right.$ coleta $)$

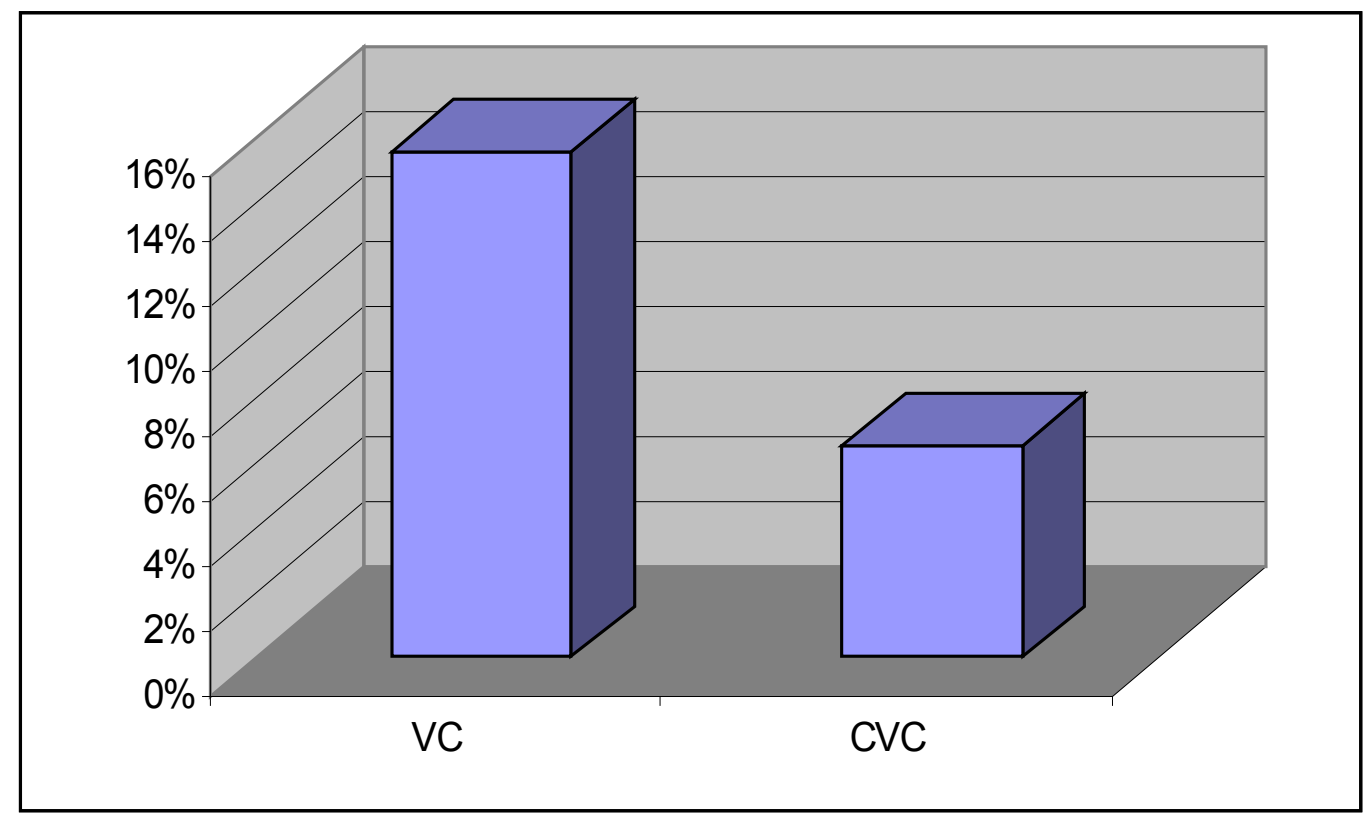

\subsubsection{Categorias de Erros}

Na Tabela 8 observamos os vocábulos produzidos de forma inadequada pelos sujeitos, na segunda coleta, e classificados por categorias de erros. Na Figura 5 verificamos a ocorrência das categorias de erros de acordo com os padrões silábicos no total de sujeitos, o qual sugere que em VC ocorrem as categorias 'vocalização' seguida de 'adição de ou acréscimo'. Já em CVC a 
maior freqüência foi de 'vocalização', 'nasalização', 'adição ou acréscimo', ‘substituição ou transferência' e 'omissão ou apagamento'.

Tabela 8: Ocorrência das Categorias de Erros nos Vocábulos - $2^{\mathrm{a}}$ coleta

\begin{tabular}{|c|c|c|c|c|}
\hline \multirow{2}{*}{$\begin{array}{l}\text { Categorias } \\
\text { de Erros }\end{array}$} & \multicolumn{2}{|c|}{ VC } & \multicolumn{2}{|c|}{ CVC } \\
\hline & Vocábulo & Ocorrências & Vocábulo & Ocorrências \\
\hline \multirow{11}{*}{$\begin{array}{l}\text { Adição ou } \\
\text { Acréscimo }\end{array}$} & eight & 1 & bag & 3 \\
\hline & olive & 1 & book & 6 \\
\hline & & & hot & 4 \\
\hline & & & light & 1 \\
\hline & & & red & 1 \\
\hline & & & sole & 2 \\
\hline & & & some & 1 \\
\hline & & & these & 1 \\
\hline & & & white & 3 \\
\hline & & & whole & 14 \\
\hline & & & wine & 12 \\
\hline & & & & \\
\hline \multirow{3}{*}{ Nasalização } & ---- & ---- & ham & 23 \\
\hline & & & ten & 2 \\
\hline & & & thin & 1 \\
\hline \multirow{2}{*}{$\begin{array}{l}\text { Omissão ou } \\
\text { Apagamento }\end{array}$} & ----- & ---- & whole & 1 \\
\hline & & & & \\
\hline \multirow{2}{*}{$\begin{array}{c}\text { Substituição ou } \\
\text { Transferência }\end{array}$} & of & 23 & Dutch & 3 \\
\hline & & & & \\
\hline \multirow{3}{*}{ Vocalização } & oil & 10 & foil & 13 \\
\hline & & & useful & 24 \\
\hline & & & & 24 \\
\hline
\end{tabular}


Figura 5: Ocorrência das Categorias de Erros de acordo com os Padrões Silábicos no Total dos Sujeitos ( $2^{\mathrm{a}}$ coleta)

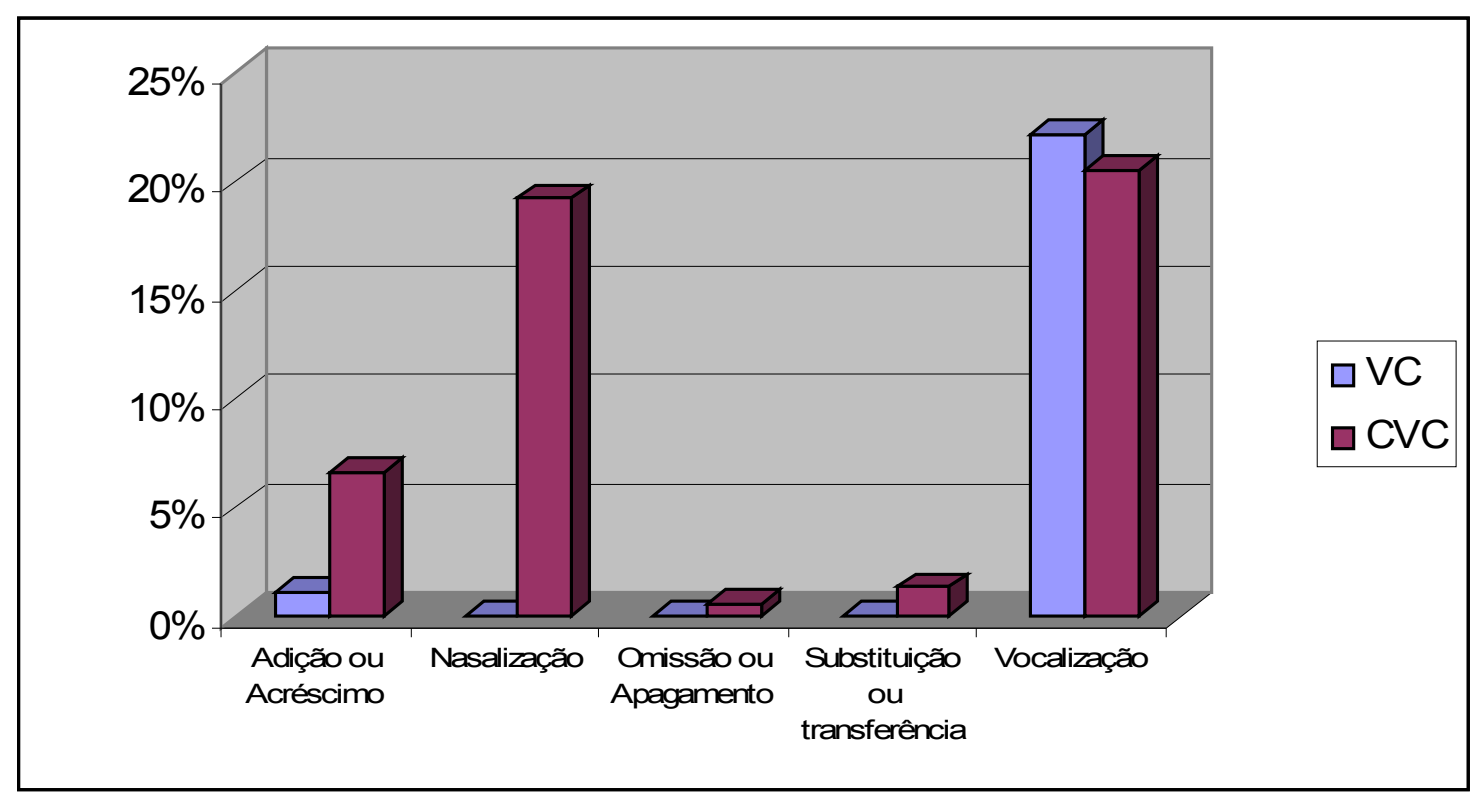

\subsection{Comparação entre as Duas Coletas}

Considerando as duas coletas, no Quadro 33 descrevemos e combinamos os padrões silábicos finais ingleses (CVC, VC) e os vocábulos articulados inadequadamente, dessa forma verificamos quais desses padrões silábicos estiveram presentes em todas as categorias de erros ou com o maior número de ocorrências, sem perder de vista a interferência da língua materna. 
Quadro 33: Categorias de Erros e Padrões Silábicos

\begin{tabular}{|l|c|}
\hline $\begin{array}{c}\text { Categorias } \\
\text { de Erros }\end{array}$ & $\begin{array}{c}\text { Padrões } \\
\text { Silábicos }\end{array}$ \\
\hline Adição ou Acréscimo & VC, CVC \\
\hline Nasalização & CVC \\
\hline \multicolumn{2}{|c|}{ CVC } \\
\hline Omissão ou Apagamento & VC, CVC \\
\hline Substituição ou Transferência & VC, CVC \\
\hline Vocalização
\end{tabular}

A partir de uma rápida leitura do Quadro 33, podemos identificar que o padrão silábico CVC esteve sempre presente em todas as categorias de erros, resultando num maior número de ocorrências. Não podemos deixar de mencionar que esse aspecto ocorreu porque a quantidade absoluta de vocábulos com esse padrão foi bem maior.

Embora possamos verificar que o padrão silábico CVC tenha sido articulado inadequadamente em todas as categorias de erros, sabemos que em algumas categorias de erros houve produções inadequadas também no início da sílaba e/ou vocábulo, no fonema consonantal inicial, mas que não fazem parte da análise dessa pesquisa. 


\subsubsection{Padrões Silábicos}

$\mathrm{Na}$ Figura 6 apresentamos o resultado das produções inadequadas dos sujeitos em cada uma das coletas, para cada padrão silábico, VC e CVC. Nela identificamos que o padrão silábico VC obteve um número absoluto menor que o padrão CVC. Podemos explicar esse fato pela quantidade de vocábulos pertencentes a cada um dos padrões. Enquanto para VC analisamos quatro vocábulos, para CVC tivemos vinte e cinco vocábulos, por isso a porcentagem de ocorrências numéricas foi maior para CVC.

Figura 6: Ocorrências de Erros em VC e CVC

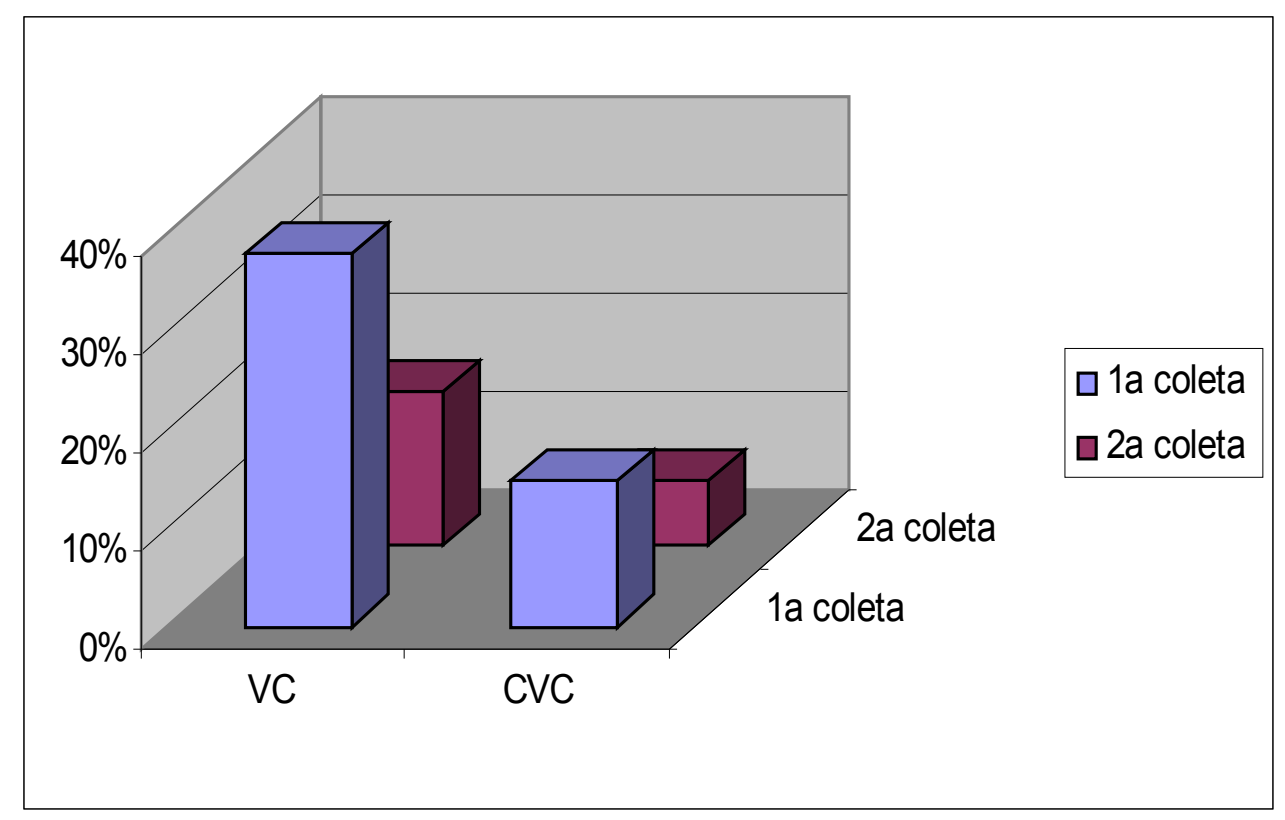


Na Tabela 9 observamos os totais absolutos de ocorrências de erros dos sujeitos, para os dois padrões silábicos, VC e CVC, e para as duas coletas. É importante mencionar que o levantamento realizado para as ocorrências engloba todas as produções inadequadas dos sujeitos, independente do número de vezes que o mesmo vocábulo foi articulado erroneamente.

Tabela 9: Ocorrência de Erros em Números Absolutos nas Coletas

\begin{tabular}{|c|c|c|c|}
\hline \multicolumn{4}{|c|}{ Ocorrência de Erros dos Sujeitos } \\
\hline $\begin{array}{c}\text { Padrões } \\
\text { Silábicos }\end{array}$ & $\begin{array}{c}1^{\text {a }} \\
\text { Coleta }^{|c|}\end{array}$ & $\begin{array}{c}\mathbf{2}^{\mathrm{a}} \\
\text { Coleta }^{\text {Total }}\end{array}$ & $\begin{array}{c}\text { Total } \\
\text { dos Erros }\end{array}$ \\
\hline VC & 85 & 35 & $\mathbf{1 2 0}$ \\
\hline CVC & 279 & 123 & $\mathbf{4 0 2}$ \\
\hline
\end{tabular}

A partir da Tabela 10, então, podemos afirmar que houve uma superação das dificuldades de produção oral dos vocábulos ingleses na $2^{\mathrm{a}}$ coleta, nos dois padrões silábicos no que se refere à quantidade numérica, tal qual aparece na Figura 6. Isso demonstra que a intervenção para a segunda gravação do texto foi valiosa para que algumas dificuldades de articulação de fonemas fossem superadas.

A estatística descritiva para os dois padrões silábicos para os 45 sujeitos encontra-se na Tabela 11, considerando-se os valores absolutos. Já na Figura 7 podemos observar a ocorrência dos erros nas duas coletas. 
Tabela 10: Estatística Descritiva dos Erros em Números Absolutos nos Padrões Silábicos - VC e CVC

\begin{tabular}{|l|r|r|}
\hline & \multicolumn{3}{|c|}{ VC } \\
\hline & $\begin{array}{c}\mathbf{1}^{\mathbf{a}} \\
\text { coleta }\end{array}$ & $\begin{array}{c}\mathbf{2}^{\mathbf{a}} \\
\text { coleta }\end{array}$ \\
\hline Total & $\mathbf{8 5}$ & $\mathbf{3 5}$ \\
\hline Média & $\mathbf{1 , 8}$ & $\mathbf{0 , 7}$ \\
\hline Máximo & $\mathbf{3}$ & $\mathbf{3}$ \\
\hline Mínimo & $\mathbf{0}$ & $\mathbf{0}$ \\
\hline Mediana & $\mathbf{2}$ & $\mathbf{1}$ \\
\hline
\end{tabular}

\begin{tabular}{|l|r|r|}
\hline \multicolumn{3}{|c|}{ CVC } \\
\hline & $\begin{array}{c}1^{\mathbf{a}} \\
\text { coleta }\end{array}$ & $\begin{array}{c}2^{\text {a }} \\
\text { coleta }\end{array}$ \\
\hline Total & $\mathbf{2 7 9}$ & $\mathbf{1 2 3}$ \\
\hline Média & $\mathbf{6 , 2}$ & $\mathbf{2 , 7}$ \\
\hline Máximo & 11 & 7 \\
\hline Mínimo & $\mathbf{1}$ & $\mathbf{0}$ \\
\hline Mediana & $\mathbf{6}$ & $\mathbf{3}$ \\
\hline
\end{tabular}

Tabela 11: Ocorrência Proporcional de Erros nos Padrões Silábicos

\begin{tabular}{|c|c|c|}
\hline & VC & CVC \\
\hline $1^{\text {a }}$ coleta & $38 \%$ & $15 \%$ \\
\hline $2^{\text {a }}$ coleta & $16 \%$ & $7 \%$ \\
\hline
\end{tabular}

O Test $T$ de Student pareado, o qual permite uma análise antes e depois do experimento, mostrou uma diferença significante tanto para o padrão silábico VC como para CVC, entre a $1^{\mathrm{a}}$ e a $2^{\mathrm{a}}$ coletas $(p<0,0001)$.

Os padrões silábicos analisados em nossa amostra estão elencados na Tabela 12, de acordo com a ocorrência de erros no total de sujeitos, em cada uma das coletas. 
Tabela 12: Vocábulos com Erros nas $1^{\mathrm{a}}$ e $2^{\mathrm{a}}$ Coletas

\begin{tabular}{|c|c|c|c|c|c|}
\hline $\begin{array}{l}\text { Padrões } \\
\text { Silábicos }\end{array}$ & $\begin{array}{l}\text { Vocábulos } \\
\text { com Erros }\end{array}$ & $\begin{array}{l}\text { Erros na } \\
1^{\mathrm{a}} \text { coleta }\end{array}$ & $\begin{array}{l}\text { Erros na } \\
2^{a} \text { coleta }\end{array}$ & \multicolumn{2}{|c|}{$\begin{array}{l}\text { Total de Erros } \\
\text { nas duas Coletas }\end{array}$} \\
\hline \multirow{4}{*}{ VC } & eight & 3 & 1 & 4 & \multirow{4}{*}{$=120$} \\
\hline & of & 40 & 23 & 63 & \\
\hline & oil & 40 & 10 & 49 & \\
\hline & olive & 2 & 1 & 3 & \\
\hline & & & & & \\
\hline \multirow{25}{*}{ CVC } & bag & 6 & 3 & 9 & \multirow{25}{*}{$=402$} \\
\hline & book & 10 & 6 & 16 & \\
\hline & cheese & 1 & 0 & 1 & \\
\hline & cure & 2 & 0 & 2 & \\
\hline & Dutch & 4 & 3 & 7 & \\
\hline & foil & 40 & 13 & 53 & \\
\hline & ham & 37 & 23 & 60 & \\
\hline & hot & 18 & 4 & 22 & \\
\hline & kilos & 2 & 0 & 2 & \\
\hline & light & 4 & 1 & 5 & \\
\hline & pot & 2 & 0 & 2 & \\
\hline & potatoes & 1 & 0 & 1 & \\
\hline & pure & 2 & 0 & 2 & \\
\hline & red & 5 & 1 & 6 & \\
\hline & sole & 31 & 2 & 34 & \\
\hline & some & 9 & 1 & 10 & \\
\hline & sure & 2 & 0 & 2 & \\
\hline & ten & 3 & 2 & 5 & \\
\hline & these & 0 & 1 & 1 & \\
\hline & thick & 3 & 0 & 3 & \\
\hline & thin & 7 & 1 & 8 & \\
\hline & useful & 38 & 24 & 62 & \\
\hline & white & 9 & 3 & 12 & \\
\hline & whole & 36 & 15 & 51 & \\
\hline & wine & 15 & 12 & 27 & \\
\hline
\end{tabular}

Ao observarmos as Figuras 5 e 7 verificamos que as ocorrências para o padrão silábico VC foi demasiadamente maior que para CVC. Foi a análise estatística que demonstrou uma inversão de valores. Isto quer dizer que quando 
tratamos o total das ocorrências para cada um dos padrões, proporcionalmente ao número absoluto de articulações inadequadas, temos como resultado inverso (Figura 7). E deste ponto de vista podemos afirmar que o padrão silábico CVC obteve uma superação maior das dificuldades de produção oral dos sujeitos.

Figura 7: Possibilidades de Ocorrências nos Padrões Silábicos, nas Duas Coletas

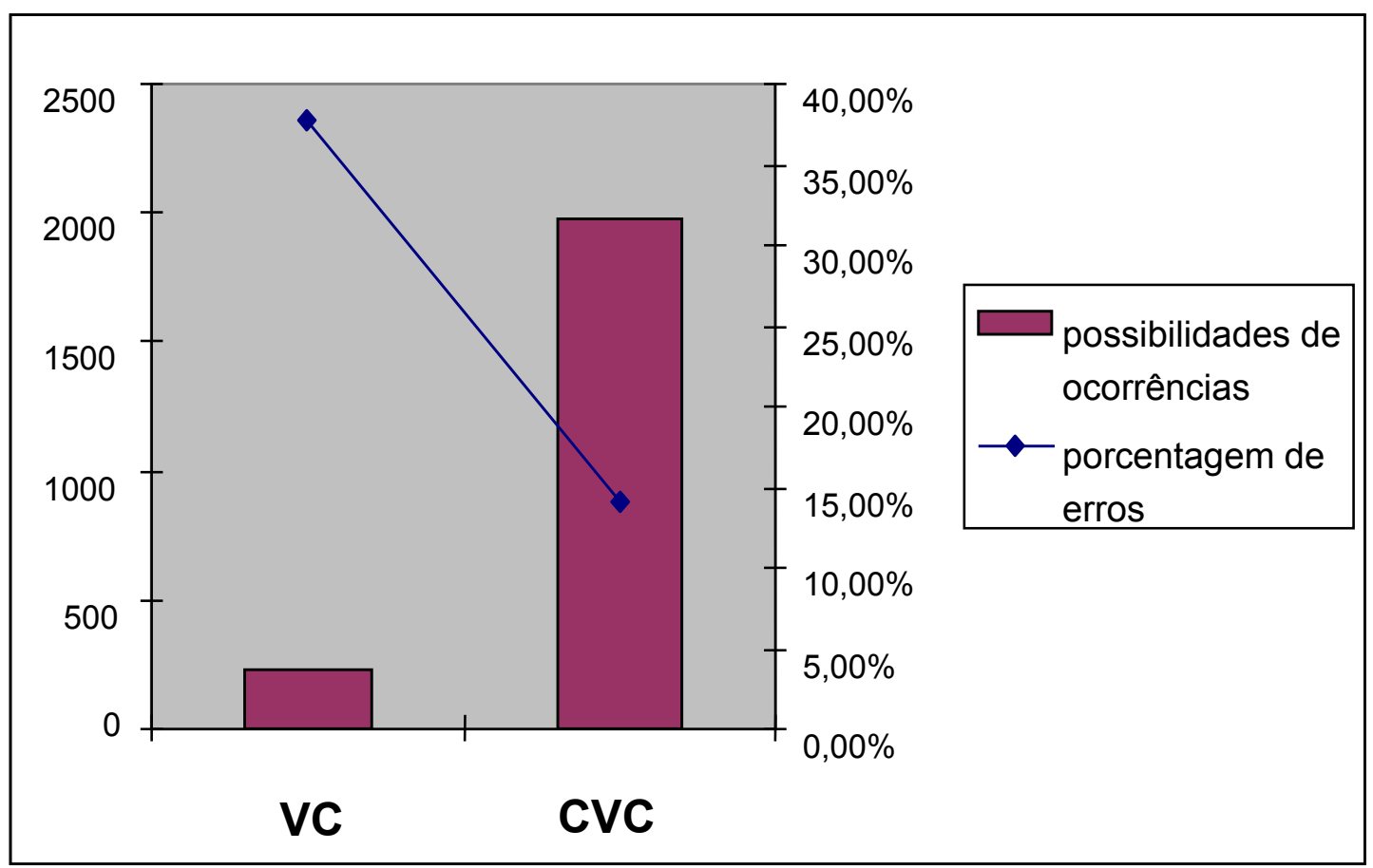

\subsubsection{Categorias de Erros}

Na Tabela 13 descrevemos as ocorrências para cada categoria de erros, dos dois padrões silábicos, VC e CVC, comparando-os nas duas coletas. 
Tabela 13: Ocorrência das Categorias de Erros nos Vocábulos da $1^{\mathrm{a}}$ e da $2^{\mathrm{a}}$ coletas

\begin{tabular}{|c|c|c|c|c|c|c|}
\hline \multirow{2}{*}{$\begin{array}{c}\text { Categorias } \\
\text { de Erros }\end{array}$} & \multicolumn{3}{|c|}{ VC } & \multicolumn{3}{|c|}{ CVC } \\
\hline & \multirow{2}{*}{$\begin{array}{l}\text { Vocábulo } \\
\text { eight }\end{array}$} & \multicolumn{2}{|c|}{$\begin{array}{c}\text { Ocorrências } \\
1^{\mathrm{a}} / 2^{\mathrm{a}}\end{array}$} & \multirow{2}{*}{$\begin{array}{l}\text { Vocábulo } \\
\text { bag }\end{array}$} & \multicolumn{2}{|c|}{$\begin{array}{c}\text { Ocorrências } \\
1^{a} / 2^{a}\end{array}$} \\
\hline \multirow{16}{*}{$\begin{array}{l}\text { Acréscimo ou } \\
\text { Adição }\end{array}$} & & 3 & 1 & & 6 & 3 \\
\hline & oil & 1 & 0 & book & 10 & 6 \\
\hline & olive & 2 & 1 & cheese & 1 & 0 \\
\hline & & & & cure & 2 & 0 \\
\hline & & & & hot & 19 & 4 \\
\hline & & & & light & 4 & 1 \\
\hline & & & & pot & 1 & 0 \\
\hline & & & & pure & 2 & 0 \\
\hline & & & & red & 5 & 1 \\
\hline & & & & sole & 11 & 2 \\
\hline & & & & some & 9 & 1 \\
\hline & & & & sure & 2 & 0 \\
\hline & & & & these & 0 & 1 \\
\hline & & & & white & 9 & 3 \\
\hline & & & & whole & 32 & 14 \\
\hline & & & & wine & 15 & 12 \\
\hline \multirow{4}{*}{ Nasalização } & & & & & & 20 \\
\hline & ---- & ---- & ---- & ham & 37 & 23 \\
\hline & & & & ten & 3 & 2 \\
\hline & & & & thin & 7 & 1 \\
\hline & & & & & & \\
\hline \multirow{4}{*}{$\begin{array}{l}\text { Omissão ou } \\
\text { Apagamento }\end{array}$} & ----- & ----- & ---- & kilos & 1 & 0 \\
\hline & & & & potatoes & 1 & 0 \\
\hline & & & & sole & 19 & 0 \\
\hline & & & & whole & 4 & 1 \\
\hline \multirow{3}{*}{$\begin{array}{l}\text { Substituição ou } \\
\text { Transferência }\end{array}$} & of & 40 & 23 & Dutch & 4 & 3 \\
\hline & & & & kilos & 1 & 0 \\
\hline & & & & thick & 3 & 0 \\
\hline & & & & & & \\
\hline \multirow{4}{*}{ Vocalização } & oil & 39 & 10 & foil & 40 & 13 \\
\hline & & & & sole & 1 & 0 \\
\hline & & & & useful & 38 & 24 \\
\hline & & & & whole & 2 & 0 \\
\hline
\end{tabular}

Nas Figuras 8 e 9 demonstramos a porcentagem de ocorrências nas categorias de erros nas duas coletas de acordo com os padrões silábicos no total de sujeitos. 
Figura 8: Ocorrência das Categorias de Erros do Padrão Silábico VC no Total dos Sujeitos

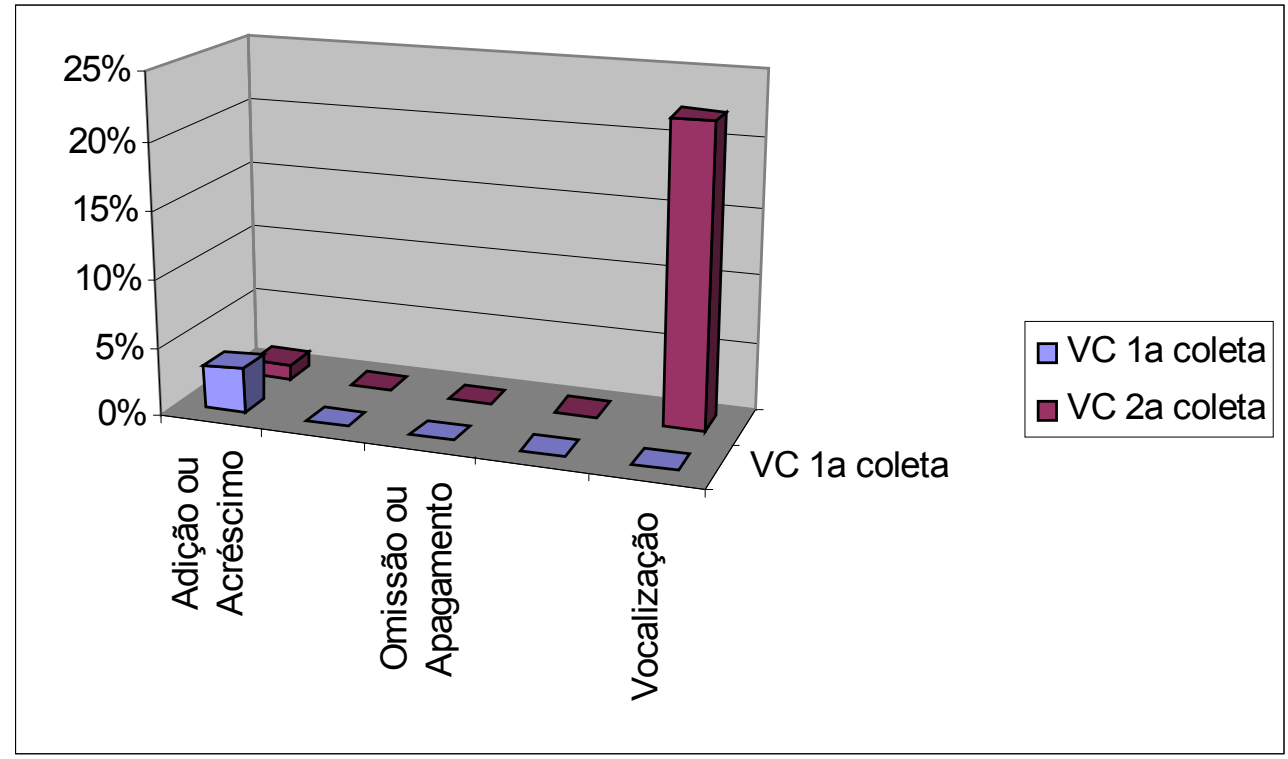

Figura 9: Ocorrência das Categorias de Erros do Padrão Silábico CVC no Total dos Sujeitos

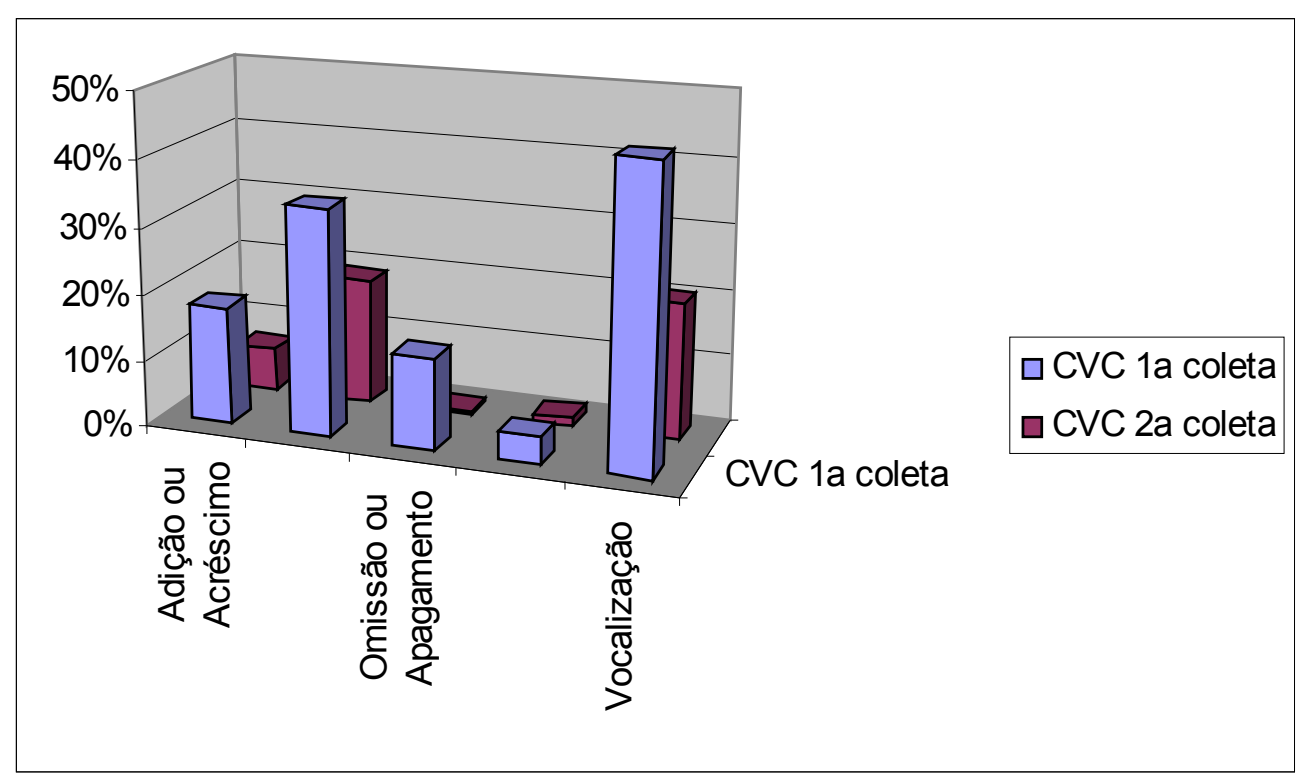




\subsection{Questionário}

Nas Tabelas 14, 15, 16, 17 e 18 são observados os dados pessoais dos sujeitos quanto ao local de nascimento, estado civil, situação ocupacional e tipo de escola do ensino médio.

De acordo com as questões de 1 a 4 , os sujeitos desta pesquisa são brasileiros, sendo 35 nascidos na cidade de São Paulo; 6 no Estado de São Paulo, um de Luiziânia, dois de Ribeirão Pires, um de Cananéia e os outros dois de São Caetano do Sul; e, 4 de outros estados do Brasil, Recife - Pernambuco, Teresina - Piauí, Aracajú - Sergipe e Guaranhuns - Pernambuco. Atualmente os 45 sujeitos do grupo residem em sua maioria na região norte e leste da cidade de São Paulo.

Tabela 14: Origem dos Sujeitos

\begin{tabular}{|c|c|c|}
\hline \multicolumn{3}{|c|}{ Sujeitos: nascidos em } \\
\hline $\begin{array}{c}\text { São Paulo } \\
\text { (cidade) }\end{array}$ & $\begin{array}{c}\text { São Paulo } \\
\text { (estado) }\end{array}$ & $\begin{array}{c}\text { Outros } \\
\text { estados }\end{array}$ \\
\hline 35 & 6 & 4 \\
\hline
\end{tabular}

A maioria dos sujeitos observados são solteiros, conforme as respostas nas questões 7 e 8 .

Tabela 15: Estado Civil dos Sujeitos

\begin{tabular}{|c|c|c|c|}
\hline \multicolumn{4}{|c|}{ Sujeitos } \\
\hline Solteiros & Casados & Divorciados & Com filhos \\
\hline 37 & 6 & 2 & 6 \\
\hline
\end{tabular}


Quanto à situação ocupacional dos sujeitos desta pesquisa, nas questões 9 e 10 notamos que há 6 sujeitos desempregados e a faixa de renda familiar com maior incidência aquela entre 5 e 10 salários (Tabela 16).

Tabela 16: Situação Ocupacional

\begin{tabular}{|c|c|c|}
\hline \multicolumn{3}{|c|}{ Sujeitos } \\
\hline Desempregados & Empregados & Renda familiar \\
\hline \multirow{3}{*}{6} & 39 & de 1 a 5 salários: 14 \\
& & de 5 a 10 salários: 18 \\
& & de 11 a 15 salários: 8 \\
& de 16 a 20 salários: 2 \\
& mais de 21 salários: 3 \\
\hline
\end{tabular}

Observamos na Tabela 17 que há uma grande parte dos sujeitos que cursou o ensino médio todo na escola pública e a concluiu antes do ano 2000, conforme as questões 11 e 12.

Tabela 17: Tipo de Escola de Ensino Médio

\begin{tabular}{|c|c|c|c|c|c|c|c|}
\hline \multicolumn{9}{|c|}{ Sujeitos } \\
\hline \multirow{2}{*}{$\begin{array}{c}\text { Escola } \\
\text { Pública }\end{array}$} & $\begin{array}{c}\text { Escola } \\
\text { Particular }\end{array}$ & $\begin{array}{l}\text { Pública e } \\
\text { Particular }\end{array}$ & Supletivo & $\begin{array}{c}\text { Antes } \\
\text { de 2000 }\end{array}$ & $\begin{array}{c}\text { Em } \\
\mathbf{2 0 0 1}\end{array}$ & $\begin{array}{c}\text { Em } \\
\mathbf{2 0 0 2}\end{array}$ & $\begin{array}{c}\text { Sem } \\
\text { data }\end{array}$ \\
\hline 33 & 4 & 7 & 1 & 3 & 6 & 1 & 3 \\
\hline
\end{tabular}

Além disso, nas questões 14 e 15 descritas na Tabela 18, a grande maioria dos sujeitos fez o ensino médio sem interrupção e apenas um sujeito já havia cursado outra graduação (Turismo). 
Tabela 18: Seqüência dos Estudos

\begin{tabular}{|c|c|c|}
\hline \multicolumn{3}{|c|}{ Sujeitos: estudos } \\
\hline Sem interrupção & $\begin{array}{c}\text { Outra } \\
\text { Graduação }\end{array}$ \\
\hline Sim & Não & Gran \\
\hline 33 & 12 & 1 \\
\hline
\end{tabular}

Conforme as questões 16 a 18 , na Tabela 19 , todos os sujeitos têm interesse em aprender uma outra língua estrangeira além do inglês. $O$ Espanhol é a língua que desperta o maior número de sujeitos interessados, seguida do Francês e do Alemão. Há 18 sujeitos que fizeram curso de inglês em diversas escolas, inclusive alguns sujeitos cursaram mais de uma escola diferente.

Tabela 19: Interesse dos Sujeitos em Aprender Línguas Estrangeiras

\begin{tabular}{|c|c|c|c|c|c|c|c|c|c|c|}
\hline \multicolumn{10}{|c|}{ Sujeitos } \\
\hline $\begin{array}{c}\text { Fizeram } \\
\text { curso de } \\
\text { Inglês }\end{array}$ & $\begin{array}{c}\text { Interesse } \\
\text { em outra } \\
\text { LE }\end{array}$ & \multicolumn{10}{|c|}{ Outra Língua Estrangeira de Interesse } \\
\hline Sim & Não & Sim & Não & Espanhol & Francês & Italiano & Alemão & Japonês & Chinês & Árabe \\
\hline 36 & 9 & 45 & 0 & 27 & 15 & 11 & 10 & 4 & 2 & 1 \\
\hline
\end{tabular}

A motivação dos sujeitos quanto à escolha do curso foi constatada na Tabela 20 que apresenta a profissão de Tradutor como objetivo maior para todos os sujeitos, de acordo com a questão 20. Se considerarmos que a resposta 'era o meu ideal' como também 'ser um tradutor', então teremos um número ainda maior de alunos com a mesma opção. 
Tabela 20: Motivo da Escolha do Curso de Tradutor

\begin{tabular}{|c|c|c|c|c|c|c|c|c|}
\hline \multicolumn{1}{|c|}{ Escolha do Curso } \\
\hline Ideal & $\begin{array}{c}\text { Profis } \\
- \\
\text { sional }\end{array}$ & $\begin{array}{c}\text { Professo } \\
\text { r de } \\
\text { inglês }\end{array}$ & $\begin{array}{c}\text { Professor de } \\
\text { português }\end{array}$ & $\begin{array}{c}\text { Professor de } \\
\text { literatura }\end{array}$ & $\begin{array}{c}\text { Traduto } \\
\mathbf{r}\end{array}$ & Intérprete & $\begin{array}{c}\text { Gosta de } \\
\text { inglês }\end{array}$ & $\begin{array}{c}\text { Sem } \\
\text { opção }\end{array}$ \\
\hline 9 & 2 & 2 & 1 & 1 & 18 & 11 & 4 & 0 \\
\hline
\end{tabular}

A questão 22 demonstra que os 45 sujeitos têm como maior motivação para estudar língua inglesa aprender mais 'sobre a cultura e os costumes do povo', 'falar e entender melhor' a língua, seguido de 'motivo profissional' e 'melhorar a habilidade de falar' (Tabela 21).

Tabela 21: Motivação para Estudar Língua Inglesa

\begin{tabular}{|c|c|c|c|c|c|c|c|c|c|}
\hline \multicolumn{10}{|c|}{ Por que estudar Língua Inglesa? } \\
\hline $\begin{array}{c}\text { Curiosi- } \\
\text { dade }\end{array}$ & $\begin{array}{c}\text { Profis- } \\
\text { sional }\end{array}$ & $\begin{array}{c}\text { Cultura } \\
\text { do } \\
\text { povo }\end{array}$ & $\begin{array}{c}\text { Falar e } \\
\text { entender } \\
\text { melhor a } \\
\text { lingua }\end{array}$ & $\begin{array}{c}\text { Melhorar } \\
\text { a leitura }\end{array}$ & $\begin{array}{c}\text { Melhorar } \\
\text { a escrita }\end{array}$ & $\begin{array}{c}\text { Melhorar } \\
\text { a fala }\end{array}$ & $\begin{array}{c}\text { Melhorar } \\
\text { a escuta }\end{array}$ inglesta \\
\hline 3 & 8 & 14 & 11 & 3 & 3 & 7 & 3 & 3 & $\begin{array}{c}\text { Melhorar a } \\
\text { capacidade } \\
\text { de traduzir }\end{array}$ \\
\hline
\end{tabular}

Para ilustrar as questões 23 e 24 detalhadamente, a Tabela 22 apresenta a opinião da maioria dos sujeitos com relação à facilidade em 'ler' a língua inglesa, enquanto outros têm mais dificuldade para 'falar' e 'ouvir' a mesma. 
Tabela 22: Níveis de Aquisição das Habilidades Lingüísticas

\begin{tabular}{|c|c|c|c|c|c|c|c|}
\hline \multicolumn{8}{|c|}{ Durante o Processo de Aquisição da LE } \\
\hline \multicolumn{3}{|c|}{ Mais fácil } & \multicolumn{5}{c|}{ Mais difícil } \\
\hline Falar & Ler & Ouvir & Escrever & Falar & Ler & Ouvir & Escrever \\
\hline 9 & 20 & 7 & 9 & 17 & 1 & 17 & 10 \\
\hline
\end{tabular}

Segundo as respostas dos sujeitos para as questões 25 e 26 , enumeradas na Tabela 23, o nível estrutural de maior dificuldade durante o processo de aquisição da língua inglesa é o 'fonético-fonológico', seguido do 'morfossintático' e do 'lexical'. Um ponto que todos os sujeitos estão de acordo é sobre a importância do aprendizado da pronúncia.

Tabela 23: Nível Estrutural e Pronúncia

\begin{tabular}{|c|c|c|c|c|c|}
\hline \multicolumn{3}{|c|}{ Nível estrutural da LE } & \multicolumn{2}{c|}{ Pronúncia } \\
\hline $\begin{array}{c}\text { Fonético- } \\
\text { fonológico }\end{array}$ & $\begin{array}{c}\text { Morfossin- } \\
\text { tático }\end{array}$ & Lexical & $\begin{array}{c}\text { Sem } \\
\text { resposta }\end{array}$ & Supérfluo & Importante \\
\hline 19 & 14 & 9 & 3 & 0 & 45 \\
\hline
\end{tabular}

Algumas questões aplicadas aos alunos buscaram relacionar-se às categorias de erros. As questões de 23 a 26 direcionam-se aos aspectos relativos ao processo durante a aquisição da língua estrangeira.

A Questão 23 aborda o aspecto: "Durante o processo de aquisição de uma língua estrangeira, você considera mais fácil: falar, ler, ouvir ou escrever?". Na Figura 10 nota-se que a maioria dos sujeitos considera mais fácil a leitura durante o processo de aquisição da língua inglesa. Quanto ao significado de $\mathbf{n} / \mathbf{c}$ representa que o sujeito assinalou mais de uma alternativa. 
Figura 10: Questão 23

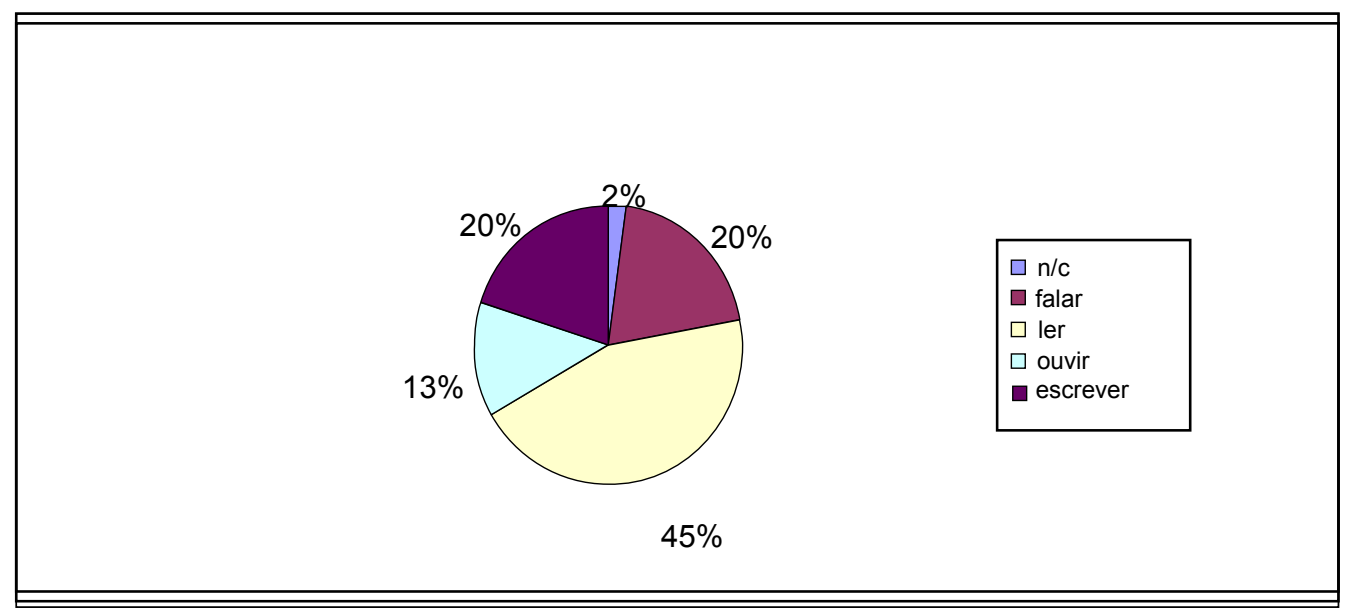

Para a Questão 24, cujo texto é "Durante o processo de aquisição de uma língua estrangeira, você considera mais difícil: falar, ler, ouvir ou escrever?", a maioria dos sujeitos considera mais difícil 'falar' e 'ouvir' durante o processo de aquisição da língua inglesa (Figura 11). Quanto ao significado de n/c representa que o sujeito não assinalou nenhuma das alternativas.

Figura 11: Questão 24

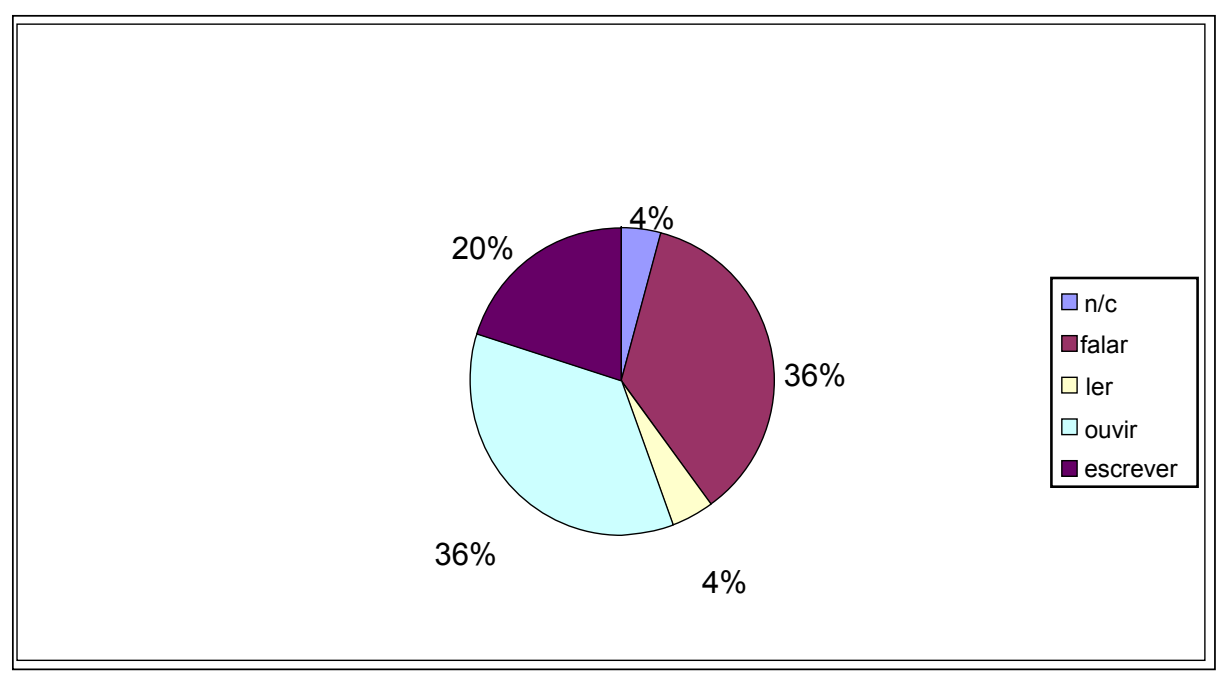


Já na Questão 25, "Que nível estrutural da língua estrangeira tem sido de mais difícil aquisição para você: fonético-fonológico, morfossintático ou lexical?", a maioria dos sujeitos demonstrou que o nível estrutural fonéticofonológico traz mais dificuldade durante o aprendizado do inglês como língua estrangeira, seguido do morfossintático e do lexical (Figura 12). $O$ item $\mathbf{n} / \mathbf{c}$ representa que o sujeito não assinalou nenhuma das alternativas.

Figura 12: Questão 25

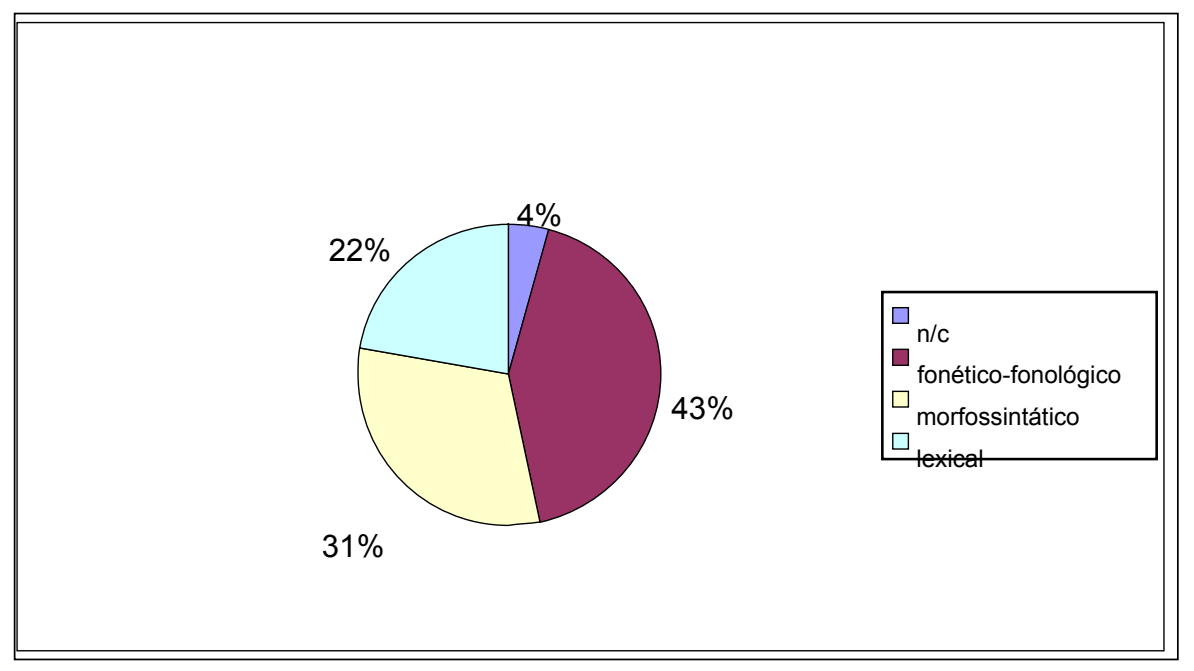

Para a questão 26, "Durante o processo de ensino/aprendizagem da língua inglesa, você considera o ensino da pronúncia: supérfluo ou importante?", todos os sujeitos desta pesquisa responderam que o ensino da pronúncia é o mais importante (Figura 13). 
Figura 13: Questão 26

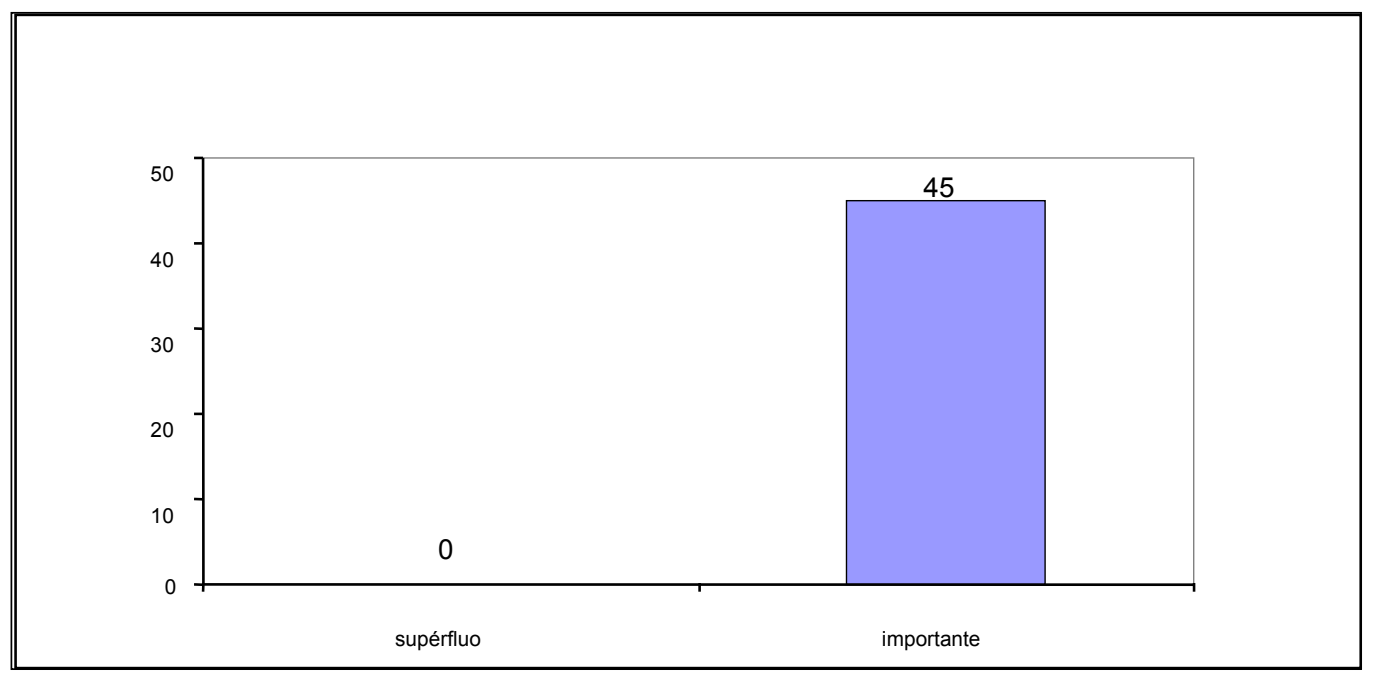

De forma geral, no questionário o item 'leitura' foi o processo considerado pelos sujeitos como de fácil aquisição, enquanto que o item 'fala' foi ressaltado como o de mais difícil aquisição.

Quanto ao nível estrutural de maior dificuldade os sujeitos identificaram o fonético-fonológico, seguido do morfossintático e este do lexical. Embora difícil de alcançar uma articulação próxima do falante-nativo, há indícios de que todos os sujeitos da pesquisa consideram fundamental a aquisição de uma produção dos fonemas da língua inglesa inteligível para a comunicação.

\subsection{Relação entre Itens do Questionário e Categorias de Erros}

Foram selecionadas as questões $23,24,25$ e 26 para as quais foram analisadas a porcentagem de erros e verificadas as ocorrências de erros nos padrões silábicos. 
Na questão 23, 17 sujeitos responderam que 'fala' é mais difícil. $\mathrm{Na}$ Figura 14 observamos a porcentagem erros de acordo com os padrões silábicos.

Figura 14: Falar é mais difícil (-VC e -CVC)

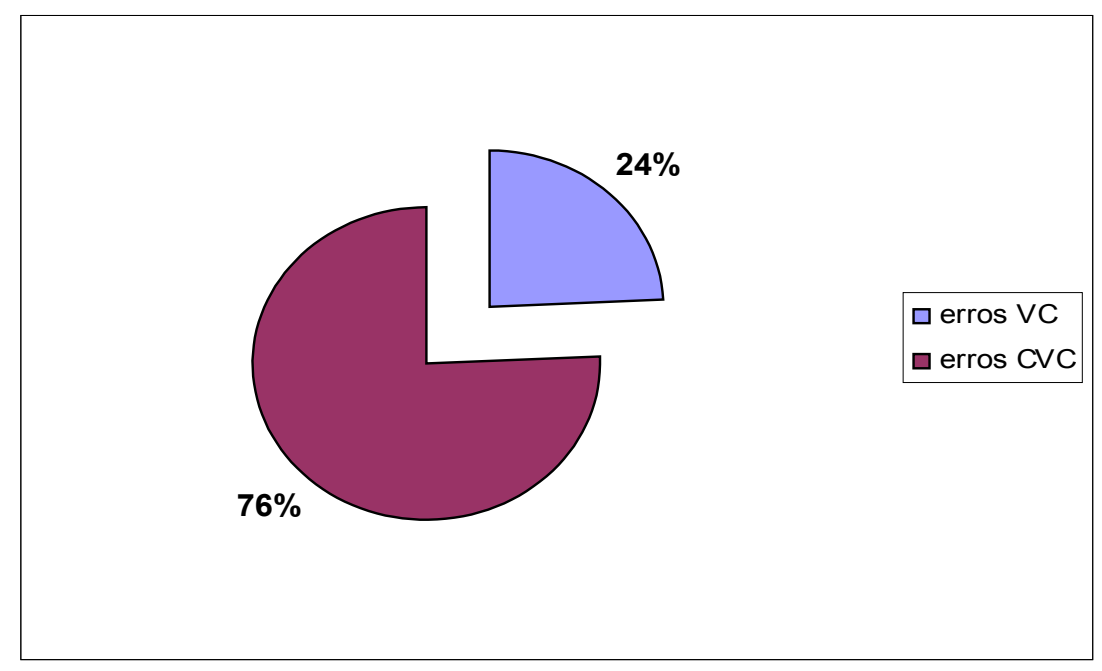

Na questão 24, 17 sujeitos responderam que 'ouvir' é mais difícil. $\mathrm{Na}$ Figura 15 verificamos a porcentagem erros de acordo com os padrões silábicos. 
Figura 15: Ouvir é mais difícil (-VC e -CVC)

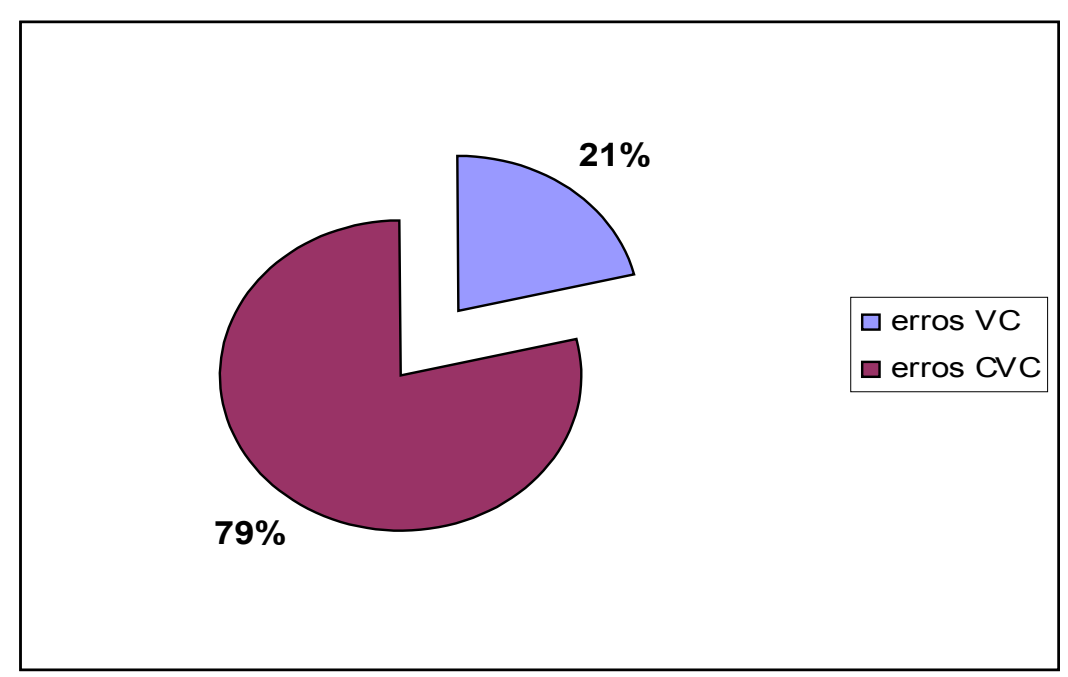

Na questão 25, 10 sujeitos responderam que 'escrever' é mais difícil. Na Figura 16 observamos a porcentagem erros de acordo com os padrões silábicos.

Figura 16: Escrever é mais difícil (-VC e -CVC)

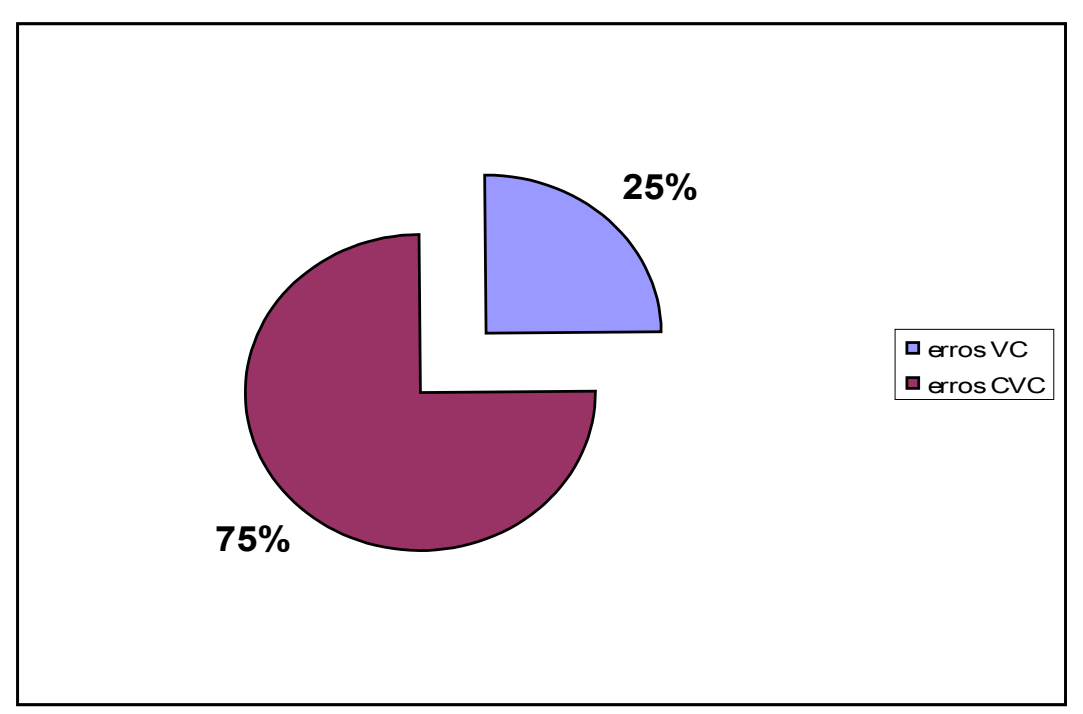


Nas questões 26, 1 sujeitos responderam que 'ler' é mais difícil. Na Figura 17 observamos a porcentagem erros de acordo com os padrões silábicos.

Figura 17: Ler é mais difícil (-VC e -CVC)

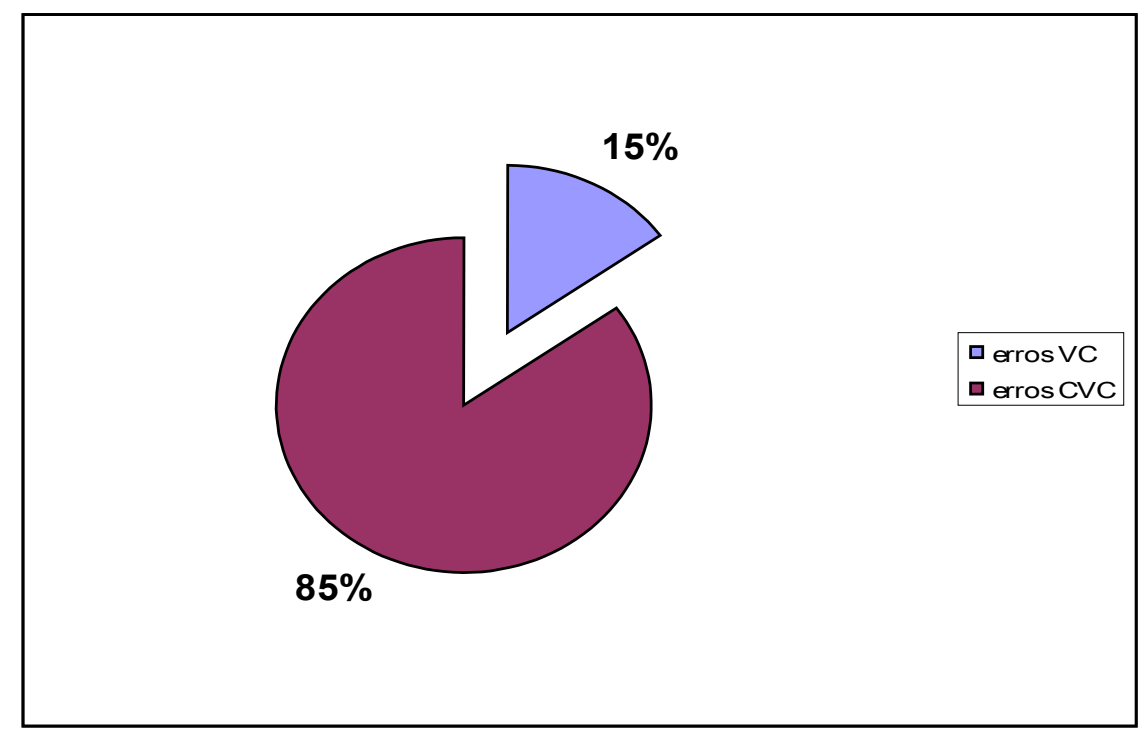

A partir das Figuras 14, 15, 16 e 17 entendemos que para os sujeitos, tanto a habilidade 'ouvir' como 'falar' são consideradas mais difíceis. Ambas foram utilizadas na leitura do texto. Embora na $1^{\text {a }}$ coleta os sujeitos tenham utilizado apenas a leitura oral, na $2^{\mathrm{a}}$ tiveram treino auditivo e oral antes da gravação. Ambas podem ser identificadas como problemáticas em nossa amostra. Fato esse que prova a veracidade da dificuldade dos sujeitos.

Na Figura 18 apresentamos as dificuldades dos sujeitos para cada uma das habilidades (falar, ler, escrever e ouvir). Nela há a proporcionalidade das escolhas dos sujeitos para as habilidades, quando consideramos o total das respostas às perguntas do questionário já mencionadas 
anteriormente. Assim, voltamos a afirmar que as habilidades consideradas pelos sujeitos como mais difíceis são 'falar' e 'ouvir', ambas com 38\% como resultado.

Figura 18: Habilidades Lingüísticas de Maior Dificuldade

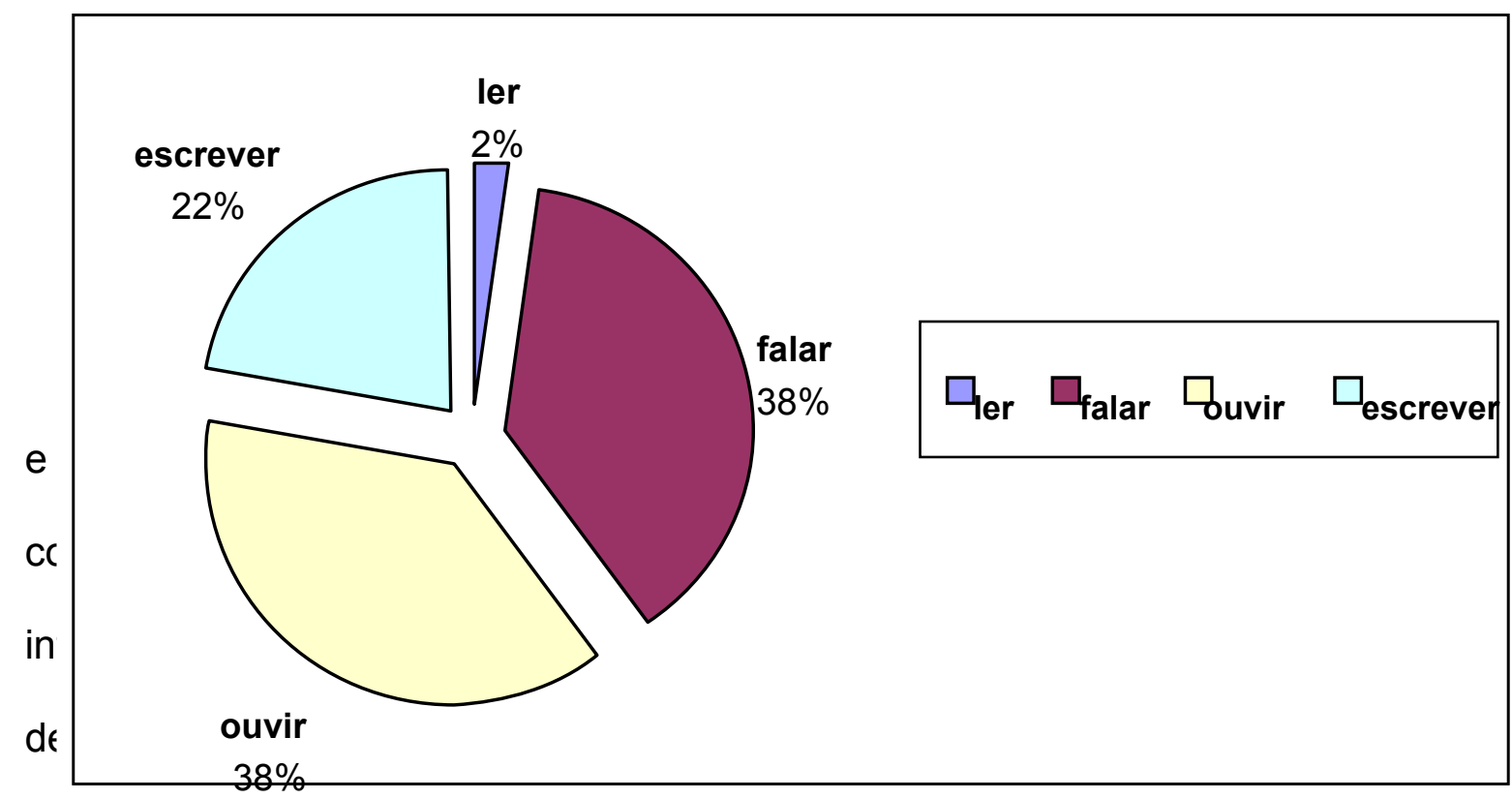

Esses erros cometidos pelos sujeitos da nossa pesquisa foram identificados e combinados com as categorias de erros. Há que se dizer aqui que já efetuamos essa relação quando a fizemos no item da análise dos padrões silábicos VC e CVC. 
DiscussÃo 


\section{Discussão}

Esse capítulo discutirá a comparação dos resultados da $1^{\mathrm{a}}$ e $2^{\mathrm{a}}$ coletas, primeiramente no que diz respeito aos padrões silábicos, as categorias de erros e as relações entre o questionário e as categorias de erros. Em seguida comentaremos sobre as implicações pedagógicas envolvidas no processo de aquisição fonológica de uma língua estrangeira, as interferências da língua materna, a importância de tratar dos contrastes entre as línguas envolvidas durante o período de aquisição, e finalmente sobre a inteligibilidade.

\subsection{As Duas Coletas}

\subsubsection{Padrões Silábicos}

$\mathrm{Na}$ amostra estudada por meio da leitura do texto, notamos que o padrão silábico VC teve mais erros proporcionalmente, principalmente em decorrência do vocábulo inglês of, o qual ocorreu com maior freqüência, apresentou na amostra uma grande influência da língua materna no momento da gravação do texto (Lado, 1957, O’Connor, 1980; Steinberg, 1985; Dalton \& Seidlhofer, 1994). Enquanto que no padrão silábico CVC embora o número absoluto de vocábulos tenha sido maior, a relação proporcional é exatamente inversa (cf. Figuras 2 e 4, p.95 e p.99). 


\section{- Os Padrões Silábicos Finais e Sua Relação com o Vocábulo Seguinte}

Dentre os aspectos importantes para a análise dos achados da pesquisa quanto aos padrões silábicos está a sua relação com o vocábulo seguinte. Tal análise permite identificar a presença de categorias de erros que possibilitam o entendimento do ocorrido durante a produção do texto pelos sujeitos.

Considerando-se o vocábulo of, em que detectamos grande ocorrência de erros, constatamos que a maioria dos sujeitos produziu articulações inadequadas, independentemente do fato do fonema inicial do vocábulo seguinte ser surdo ou sonoro. Nesse caso não houve a criação de uma regra, mas sim uma interferência da língua materna, conforme CaglaRI \& CAglaRI (2000), pois esse aspecto está relacionado à transparência da ortografia e à leitura oral da língua portuguesa, fato esse que não ocorre na língua inglesa. Para a produção oral do vocábulo em questão, o falante do Português Brasileiro, leu o mesmo fonema do da grafia, ou seja, a letra -f pelo fonema / -f /.

Ainda em relação a esse vocábulo identificamos outra possibilidade de explicação ao considerarmos as categorias de erros. Se a articulação correta do vocábulo of é / ov /, e a maioria dos sujeitos da nossa pesquisa articulou erroneamente o vocábulo como se fosse / of /, afirmamos que a categoria de erros 'substituição ou transferência' da língua materna dos sujeitos foi a responsável por esse fato (Lado, 1957; Klein, 1986; Caglari \& CagliarI, 2000). 
Observemos as ocorrências inadequadas dos sujeitos no momento da leitura do vocábulo of no texto:

$$
\begin{aligned}
& \text { of green } \rightarrow \text { / of 'gri:n / } \\
& \text { of mixed } \rightarrow \quad \text { / of 'mikst / } \\
& \text { of apples } \rightarrow \quad \text { / əf 'æplz / } \\
& \text { of large } \quad \rightarrow \quad \text { / of la:rdz / } \\
& \text { of hot } \rightarrow \quad \text { / of lhot / } \\
& \text { of_corn } \rightarrow \quad \text { / of lko:rn / } \\
& \text { of_bananas } \rightarrow \text { / əf bəlnænəz / } \\
& \text { of the } \rightarrow \quad \text { / әf Џә / } \\
& \text { of light } \rightarrow \quad \text { / of lait / } \\
& \text { of brown } \rightarrow \text { / of Ibraun / } \\
& \text { of_orange } \rightarrow \text { / of 'prindz / } \\
& \text { of_Dutch } \rightarrow \quad \text { / of } \mathrm{l} \mathrm{d} \wedge \mathrm{t} \int \mathrm{I}
\end{aligned}
$$

Não podemos deixar de mencionar que houve articulações corretas e tentar explicá-las é fácil. Os sujeitos realizaram naturalmente o / ov /, quando o vocábulo seguinte iniciava por um fonema vocálico (SILVEIRA, 1986 e 1988; Gass \& Selinker, 2001; Cristófaro-Silva, 2002). Neste caso também houve transferência da língua materna dos sujeitos, uma vez que em português estamos habituados a sonorizar, por exemplo, a letra $\mathbf{- s}$ final dos vocábulos, se em 
seguida ocorrer um vocábulo que inicie por uma vogal. Tal qual o exemplo da língua portuguesa:

$$
\text { casas_azuis } \rightarrow \text { /'kazaz a'zuIS / }
$$

Os sujeitos de nossa pesquisa utilizaram esse mesmo recurso para o vocábulo inglês some. A partir dessa contextualização dos vocábulos em ambas as línguas, afirmamos que as ocorrências variaram segundo o contexto fonológico do vocábulo seguinte, pois quando havia um vocábulo iniciado por um fonema vocálico, nem todos os sujeitos produziram uma vogal nasalizada no caso de some, mas sim o fonema / -m / unido ao vocábulo seguinte. Vejamos os exemplos:

$$
\begin{aligned}
& \text { of_orange } \rightarrow \text { / əv I Drindz / } \\
& \text { some_olive } \rightarrow \text { / som Ioliv / }
\end{aligned}
$$

No padrão silábico CVC notamos ainda um aspecto interessante do ponto de vista da superação dos erros de alguns vocábulos, ou seja, na $2^{\mathrm{a}}$ coleta os sujeitos articularam corretamente vocábulos que foram produzidos erroneamente na $1^{\text {a }}$ coleta. Assim, observamos que os vocábulos cheese, cure, kilos, pot, potatoes, pure, sure e thick não tiveram ocorrências inadequadas na segunda gravação, após treino em sala de aula com a professora da disciplina 'Pronúncia da Língua Inglesa'. Esse fato pode ser explicado por CelCE-MuRCiA \& Goodwin (1991) que concordam que os padrões silábicos podem trazer dificuldades para o estudante em ambas as línguas envolvidas, mas os 
professores devem se preparar para ajudar a superar tais dificuldades. E foi exatamente isto que aconteceu. Os alunos superaram suas dificuldades depois de treinar o texto da leitura.

Ressaltamos que os sujeitos dessa pesquisa repetidamente utilizaram recursos de sua própria língua para realizar a gravação do texto, tanto na $1^{a}$ como na $2^{a}$ gravação. Notamos uma melhora significativa para alguns dos sujeitos, o que prova que naturalmente são pessoas que têm mais facilidade para apreender e internalizar os ensinamentos da disciplina de Pronúncia da Língua Inglesa e, conseqüentemente articular os fonemas corretamente.

As seguintes ocorrências podem ser explicadas de formas diversas. Os vocábulos que seguiram cure, kilos, pot, potatoes, pure, sure e thick foram iniciados por uma vogal. Assim, segundo HARMER (1994) a memória auditiva do sujeito foi utilizada para a produção correta dos vocábulos, sendo realizada com facilidade, conforme as regras fonológicas do inglês e mesmo do português. Em outras palavras, as ocorrências inadequadas foram superadas não somente por causa do treino, mas afirmamos que mais uma vez as regras da língua materna para a produção dos vocábulos foram utilizadas pelos sujeitos ao articular contextos similares. 


$$
\begin{array}{ccc}
\begin{array}{c}
\text { cure_if } \\
\text { kilos_of }
\end{array} & \rightarrow \quad / \text { kujr If / } \\
\text { pot_of } & \rightarrow & / \text { pot ov / } \\
\text { potatoes_eight } & \rightarrow & / \text { po'teItouz eIt / } \\
\text { pure_and } & \rightarrow & / \text { pjur ond / } \\
\text { sure_it's } & \rightarrow & / \text { Jur Its / } \\
\text { thick_or } & \rightarrow & / \text { OIk o:r / }
\end{array}
$$

Quanto ao vocábulo cheese, esse é seguido por cut e a explicação para a realização desses vocábulos é que houve a introdução de uma pausa silenciosa, ou seja, houve a real produção para cada um dos fonemas dos vocábulos em questão. Pois nesse caso a articulação dos sujeitos foi realizada pausada e corretamente para ambos os vocábulos, demonstrando que as hipóteses de WIDDOWSON (1984) e KRASHEN (1987) estavam corretas ao afirmar que se a informação expressa estiver correta, a articulação dos vocábulos também estarão corretos.

$$
\text { cheese_cut } \rightarrow / \text { t } \mathrm{t} \text { iiz k^t / }
$$

Outro aspecto importante que devemos abordar aqui é o fato de apenas na $2^{\mathrm{a}}$ coleta houve uma única ocorrência inadequada do vocábulo these. Parece-nos que não houve relação com o vocábulo seguinte, pois a explicação que damos para essa seqüência está ligada à estratégia, chamada de elisão por autores tais como O'Connor (1980), RoAch (1983), Baker \& Goldstein (1990) e Dalton \& Seidlhofer (2004). É utilizada pelos falantes nativos da língua inglesa, e 
nada mais é que uma simplificação oral da língua, uma facilidade de se produzir os vocábulos sem esforço. Então, concordamos que essa estratégia foi corretamente utilizada pelos sujeitos de nossa pesquisa. Assim, pode ser entendida que um dos fonemas foi deixado de lado para que a fala fluente fosse alcançada.

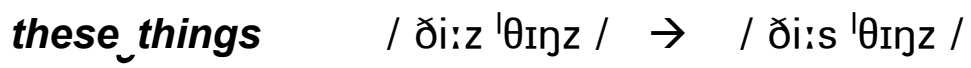

\subsubsection{Categorias de Erros}

Os resultados encontrados nas ocorrências para cada categoria de erros, nas duas coletas podem ter duas possibilidades de explicação. A relação dos fonemas no interior do vocábulo e a relação dos fonemas finais com os fonemas iniciais do vocábulo subseqüente. Então discutiremos cada uma das categorias e os vocábulos articulados erroneamente.

\section{a) Adição ou Acréscimo}

Nossa amostra obteve as seguintes ocorrências: eight, oil, olive, bag, book, cheese, cure, hot, light, pot, pure, red, sole, some, sure, these, white, whole e wine. Para todos os vocábulos foi adicionado uma vogal de apoio ao fonema consonantal final. Fato esse que é explicado pela interferência da língua materna, no caso dos nossos sujeitos, o português (LADo, 1957; Coseriu, 1979; Mascherpe, 1970; O’Connor, 1980, Steinberg, 1985; Klein, 1986; Celce-Murcia \& Goodwin, 1991; Dalton \& Seidlhofer, 1994; Schumaker, White \& Zanettini, 2002; 
Poedjosoedarmo, 2004). Devido ao fato de não ser comum existir sílabas terminadas em fonemas consonantais, o sujeito utiliza uma vogal de apoio para concluir o vocábulo.

b) Nasalização

Para essa categoria de erro seguem as ocorrências: ham, ten e thin. Nesses vocábulos a vogal que antecede o fonema consonantal final, foi nasalizada, como o falante do português está acostumado a fazê-lo. Assim podemos afirmar que por causa da interferência da língua materna, a categoria de erro 'nasalização' ocorreu em nossos dados (CÂMARA JR, 1970 e 1971; MASCHERPE, 1970; Silveira, 1988 e 1986; Cristófaro-SiLva, 2002).

c) Omissão ou Apagamento

Nessa categoria de erros obtivemos apenas algumas articulações inadequadas: sole, whole, kilos e potatoes. Para os vocábulos sole e whole, houve a omissão do fonema [ † ], enquanto para os vocábulos kilos e potatoes, o fonema consonantal final / $\mathrm{s}$ / foi apagado. Esses aspectos podem ser explicados de algumas maneiras: ou o sujeito ainda não havia internalizado o vocábulo corretamente (KLEIN, 1986), ou não houve uma memorização auditiva (HARMER, 1994), ou mesmo os fonemas não foram descriminados pelo ouvinte antes da leitura (SILVEIRA, 1988 E 1986). Pois os sons podem ser captados segundo um padrão acústico e psicológico que não atende a articulação exata do vocábulo (Coseriu, 1979; Steinberg, 1985; Callou \& Leite, 1995). 
d) Substituição ou Transferência

Essa categoria de erros também não teve uma quantidade significativa de ocorrências. Poderíamos tentar englobá-la em outras categorias, mas preferimos mantê-la de modo que pudéssemos melhor explicá-la.

As ocorrências foram: of, Dutch, thick e kilos. O vocábulo of, foi o que mais teve ocorrências do mesmo tipo, houve uma substituição do fonema inglês pela letra do vocábulo no momento da sua produção, ocasionando uma transferência por um fonema da língua materna (LADO, 1957; CoserIU, 1979; Mascherpe, 1970; O’Connor, 1980, Steinberg, 1985; Klein, 1986; Celce-Murcia \& Goodwin, 1991; Dalton \& Seidlhofer, 1994; Schumaker, White \& Zanettini, 2002; Poedjosoedarmo, 2004).

Para explicar a ocorrência de articulações inadequadas do vocábulo Dutch, declaramos que os sujeitos substituíram-no por outros vocábulos da língua inglesa, tais como: duck ou ducks e just. Todos as opções de produções dos sujeitos foram esdrúxulas, não cabendo no contexto da leitura nenhuma das possibilidades, ocasionando a substituição do vocábulo (LADO, 1957; KLEIN, 1986).

O vocábulo thick, por sua vez sofreu uma transferência de vocábulo, ou seja, o sujeito articulou-o como se fosse o vocábulo think. Houve uma substituição de vocábulos (LADO, 1957; CosERIU, 1979).

Quanto ao vocábulo kilos, houve apenas duas ocorrências na $1^{\text {a }}$ coleta. Os sujeitos apoiaram-se em sua língua materna para articular a letra $\mathbf{- s}$ final do vocábulo, mantendo a mesma articulação que utilizariam para falar a 
língua portuguesa (CÂmara JR, 1970 e 1971; Silveira, 1988 e 1986; CRIStófaroSilva, 2002; Silveira, 1988 e 1986; Schumaker, White \& ZanetTini, 2002).

e) Vocalização

Essa categoria de erros traz dificuldade para o falante do português da cidade de São Paulo, pois esse não produz o -I pós-vocálico. As ocorrências para esta categoria foram: oil, foil, sole, whole e useful. Todos foram vocalizados no momento da sua produção, ocasionando uma transferência por um fonema da língua materna (Lado, 1957; CÂmara JR, 1971; Coseriu, 1979; Steinberg, 1985; Silveira, 1988 e 1986; Callou \& Leite, 1995; Cristófaro-Silva, 2002). Os fonemas utilizados pelos sujeitos desta pesquisa foram $/ \mathrm{w} / \mathrm{e} / \mathrm{U} /$.

Portanto, a língua materna teve papel fundamental para a explicação das categorias de erros que utilizamos nessa pesquisa para justificar a ocorrência de produções inadequadas da nossa amostra ('adição ou acréscimo', 'nasalização', 'omissão ou apagamento', 'substituição ou transferência' e (vocalização'), verificamos que depois do treino auditivo e oral os sujeitos reduziram o número de vocábulos com erros (cf. Tabela 11). Isso nos leva a crer que a identificação das dificuldades nas habilidades 'ouvir' e 'falar' pelos sujeitos, foram escolhas adequadas para representar exatamente essas ocorrências. Para citarmos alguns estudiosos como Lado (1957); CÂmara JR, 1970 e 1971; MAScherpe (1970); Coseriu (1979); O'Connor (1980); Roach (1983); Widdowson (1984); Steinberg (1985, 2006); Silveira (1986, 1988); Krashen (1987); Odlin (1989); Dalton 
\& Seidlhofer (1994); Callou \& Leite (1995); Gass \& Selinker (2001); Cristófaro-Silva (2002); Jenkins (2002); Schumaker, White \& Zanettini (2002); Poedjosoedarmo (2004); SснÜтz (2004a, 2005), pesquisaram sobre ensino de língua materna e estrangeira. Todos discutem a importância do estudante em aprender a ouvir antes de produzir os sons da língua. Isso quer dizer que o ouvinte deve utilizar uma série de estratégias de aquisição da língua materna para alcançar a proficiência desejada na língua-alvo (Coseriu, 1979; Steinberg, 1885 e 2006; Harmer, 1994; Cagliari \& Cagliari, 2000; Gass \& Selinker, 2001).

Assim acreditamos que esse experimento pode contribuir com a melhoria do ensino do Inglês como língua estrangeira na medida em que faz constatações caracterizadas por categorias de erros, pois com elas foi possível prever as possíveis articulações inglesas incorretas na fala dos sujeitos adultos. E, acrescentamos que a descrição e apresentação das categorias de erros vão além da explicação baseada apenas na substituição, acréscimo ou omissão de um fonema por outro, visto que várias ocorrências são agrupadas numa mesma categoria de acordo com o tipo da articulação inadequada realizada pelo sujeito durante a gravação.

\subsection{Relação entre Questionário e Categorias de Erros}

Um dos interesses da presente pesquisa foi verificar a relação entre o julgamento do sujeito frente a aprendizagem do inglês como língua estrangeira. Assim, analisamos a ocorrência das categorias de erros propostas em função das respostas às questões 23 a 26 do questionário aplicado. De forma 
geral os estudantes afirmaram que: a leitura é mais fácil que as demais habilidades; é mais difícil falar e ouvir do que escrever e ler; a maior dificuldade está no nível fonético-fonológico; a pronúncia é muito importante para a profissão de intérprete.

Porém, esse aspecto nos faz refletir e afirmar que é absolutamente real a relação dos itens 'falar e ouvir' do ponto de vista do aprendizado fonético-fonológico de uma língua. Desta forma, se os sujeitos afirmam que a leitura é uma das habilidades mais fáceis e por outro lado, a fala é a mais difícil, parece que ler em voz alta torna-se uma habilidade que o estudante pode ter um certo grau de dificuldade, uma vez que os mesmos articularam os vocábulos com diversos tipos de erros (LADO, 1957; KLEIN, 1986; HARMER, 1994).

Quanto ao item do nível fonético-fonológico apresentar para os estudantes uma grande dificuldade, a explicação plausível nada mais é do que retomar a dificuldade da leitura oral ou da fala. E, ainda, podemos acrescentar o item sobre pronúncia que os sujeitos afirmam ser importantíssimo para profissão, principalmente para a de intérprete. Fato esse que nos leva a concordar que nessa pesquisa lidamos com a habilidade lingüística de maior dificuldade para os estudantes adultos que aprendem inglês como língua estrangeira. Este aspecto foi abordado por estudiosos como Lado (1957), Slama-Cazacu (1979), Krashen (1987), Schüтz (2003b e 2004b), et alli.

A produção correta dos vocábulos está diretamente ligada aos padrões silábicos e por conseqüência, às categorias de erros.

$\mathrm{Na}$ verdade as questões foram pensadas justamente para 
verificar se os estudantes entendem a necessidade que há em se aprender a articulação dos vocábulos ingleses, durante o período de aquisição fonológica da língua estrangeira. E, o que podemos declarar é que eles têm consciência disto, visto que além de afirmarem nas respostas do questionário, apresentaram diversos tipos de dificuldades no momento da $1^{\text {a }}$ gravação. E ao compararmos com a $2^{a}$ gravação do texto notamos que as dificuldades de articulação dos fonemas foram parcialmente solucionadas, pois sabemos que além dos estudantes realizarem vários tipos de treinos fonéticos e fonológicos nas aulas, também foram submetidos a um treino do texto com a professora da disciplina, uma semana antes da gravação (CRISTÓFARo-SILVA, 2002; JeNKINS 2002; SchUMACKER, White \& Zanettini, 2002; SchütZ, 2004a e 2005).

\subsection{Implicações Pedagógicas}

\subsubsection{A interferência da língua materna}

Uma vez decidido o corpus a ser trabalhado, identificamos vários aspectos que interferiram no aprendizado fonético-fonológico da língua inglesa. E, conhecendo a diversidade de problemas de interferência da língua materna durante o aprendizado de uma segunda língua, o que mais nos chamou a atenção nessa amostra foi a quantidade de ocorrências que apresentaram o acréscimo de uma sílaba aos vocábulos na leitura oral. Essa é uma das características da língua inglesa, possuir vocábulos que terminem com uma variedade de fonemas consonantais (Gimson, 1962; O'Connor, 1980; RoACH, 1983; Steinberg, 1985 e 2006; Schumaker, White \& Zanettini, 2002, et alli). As sílabas finais da língua 
portuguesa terminam com um número pequeno e restrito de fonemas consonantais (CÂmara JR., 1970; Silveira, 1986 e 1988; Cristófaro-Silva, 2002). Nossos dados também a comprovam. E embora essa já tenha sido amplamente discutida por vários estudiosos, reafirmamos que as interferências da língua materna ocorrem e se o professor as conhece, pode auxiliar o estudante a superar suas dificuldades.

Essa diferença entre as línguas envolvidas ocorre na nossa amostra, pois os sujeitos tiveram mais dificuldade na produção das consoantes inglesas em final de vocábulo durante a primeira coleta devido ao fato de realizarem a primeira gravação sem treino da leitura do texto em voz alta, o que algumas vezes resultou numa produção oral inadequada. Após a realização do treino oral durante a aula com o auxílio da professora, pudemos observar que os sujeitos superaram parte de suas dificuldades na segunda gravação. Houve uma adequação de apenas alguns vocábulos do texto (CELCE-MurCiA \& Goodwin, 1991). Essa ocorrência demonstra que não houve preparo suficiente por parte dos sujeitos da pesquisa e por esta razão, podemos concluir que o ensinoaprendizagem da pronúncia é importante para os sujeitos, como eles mesmos afirmaram no questionário.

Ao considerarmos as particularidades fonológicas (o plural dos substantivos, a $3^{a}$ pessoa do singular do tempo presente do indicativo, o caso genitivo ou possessivo, o passado dos verbos regulares) detectamos que muitas das ocorrências estão relacionadas às categorias de erros denominadas 'acréscimo ou adição de sílaba' ou 'substituição ou transferência' (LADO, 1957; Schumaker, White \& ZANETtINI, 2002, et alli). 
Quanto a alofonia diferente percebemos que para a ocorrência do fonema lateral há notoriamente ocorrências relacionadas à categoria de análise 'vocalização'. E quanto à ocorrência dos fonemas ingleses finais oclusivos e fricativos alveolares pudemos notar que o fato de serem semelhantes aos do português, apresentaram também as seguintes categorias de erros 'acréscimo ou adição de sílaba' ou 'substituição ou transferência' em sua produção. Ainda podemos afirmar que o ato de ler em voz alta faz com que tenhamos a interferência do vocábulo escrito, como afirmam O'CoNNOR (1980), STEINBERG (1985 e 2006), Cristófaro-Silva (2002), Schumaker, White \& Zanettini (2002) e Schütz (2004b). Do ponto de vista fonológico, podemos considerar que a língua portuguesa é mais fácil de ser pronunciada que a língua inglesa, uma vez que a maioria das letras é representada por símbolos fonéticos que são semelhantes a elas; assim a produção dos vocábulos torna-se menos problemática, porém o mesmo não acontece com a língua inglesa que possui seu inventário fonológico com distinções entre as letras e os fonemas. Enquanto em português a letra dos vocábulos pode coincidir com o fonema, em inglês o mesmo fonema pode ser produzido de diferentes maneiras, dependendo do vocábulo em que for inserido. Podemos citar como exemplo, a letra e, que está presente nos vocábulos me / $\mathrm{mi}$ /, set / set /, enough / in^f/ e mine / main /, mas cada uma delas com sua articulação específica. Cada um dos vocábulos apresenta uma possibilidade de produção, nas respectivas transcrições da vogal e encontramos: / i: /, / e /, / I / e nenhuma possibilidade de articulação. 
De acordo com a nossa pesquisa observamos que das três possibilidades de interferência da língua materna para o aprendizado da língua estrangeira, somente as particularidades fonológicas e a alofonia diferente fizeram parte de nossos dados, uma vez que não tivemos em nossa coleta vocábulos que terminem com os fonemas interdentais ou mesmo com o glotal desvozeado. Assim, foram desprezadas as interferências relacionadas à proximidade fonética.

É imprescindível comentar que o ambiente em que o último fonema consonantal de um vocábulo se une ao outro que inicia o seguinte, temos que explanar mais uma vez algumas das possibilidades de modo que possamos elencá-los sem perder de vista a nossa amostra.

Para facilitar nossa explicação e discussão começaremos pelos vocábulos que terminam num fonema consonantal e o seguinte que inicia por um fonema vocálico. É o caso das treze seqüências de fonemas: red or, book...a, thick or, bag of, of apples, of orange, olive oil, kilos of, cure if, pure...and, sure it's, some olive, wine...a. Todos esses fonemas consonantais sofrem no momento da fala de uma ligação (chamado em inglês de linking), isto é, há uma união de ambos vocábulos, que ao serem produzidos pelo falante parecem um só (Hewings, 2004; Hewings \& Goldstein, 2000). Por exemplo, thick or torna-se como a seqüência transcrita / ${ }^{\prime} \theta \mathrm{Ik}$ ər/21.

Esse aspecto, essa ligação dos dois vocábulos, com um fonema consonantal final e um vocálico inicial, é natural na comunicação tanto para a língua inglesa como para a língua portuguesa. Desta forma alguns de nossos

\footnotetext{
${ }^{21} \mathrm{O}$ linking pode acarretar num primeiro momento na confusão entre os vocábulos. Para sanar sua dúvida o ouvinte irá recorrer ao conjunto de vocábulos utilizados para aquele contexto, o que o fará ser capaz de identificar os vocábulos utilizados pelo falante.
} 
sujeitos que articularam corretamente a seqüência de fonemas entre os vocábulos, pois mantiveram o ritmo necessário durante a leitura do texto, nada mais fizeram que utilizar um recurso da sua própria língua materna.

Anteriormente já explicamos o que acontece com a seqüência Dutch cheese. Na verdade o fonema que inicia o vocábulo subseqüente é o mesmo que termina e que o antecede, tornando muito fácil para o falante produzir essa ligação, o linking, recurso este que mais uma fez foi efetuado pela maioria dos sujeitos da amostra (Hewings, 2004; Hewings \& Goldstein, 2000).

Destacamos que seria um estilo de fala bastante incomum se os vocábulos fossem pronunciados um por um, pausadamente, fato que levaria o falante a produzir todos os sons do vocábulo; e, isto com certeza não daria condições para que se criasse um ambiente confortável para a fala acontecer. Seria uma fala muito cuidadosa e incomum. A estratégia que o estudante pode utilizar chama-se elisão e é comumente utilizada pelos falantes nativos da língua inglesa, tornando a seqüência dos vocábulos mais fácil de ser produzida (BAKER \& Goldstein, 1990; Dalton \& Seidlhofer, 2004; O'Connor, 1980; e, Roach, 1983; et alli). Assim a fala fluente é atingida, proporcionando uma fala absolutamente confortável e correta.

Explicando as seqüências em que o -I pós-vocálico ocorreu em nossos dados, temos 3 exemplos: foil...some, oil and, useful new, que os sujeitos articularam a letra I como um fonema vocálico, 'o' ou 'u'. Esse recurso é utilizado pelo falante do português ao produzir vocábulos com o I pós-vocálico como fatal - [ faltaw ], pois é assim que esse fonema é produzido, o falante do português utiliza o processo fonológico conhecido como vocalização. 
Entretanto, as seqüências como sole ... five e whole Dover, algumas vezes tiveram a letra -e articulada pelos sujeitos, o que levou-os a adicionar uma sílaba ao primeiro vocábulo, sole ... five [ 'sow/I faIv ]. Esse aspecto também ocorre na língua portuguesa, ou seja, a letra -e final deve ser articulada, deve formar uma outra sílaba, fato este que não pode ocorrer na leitura ou fala de vocábulos da língua inglesa. Mais uma vez podemos comprovar, que a interferência da língua materna para na produção dos fonemas finais ingleses é um aspecto que se repete até o momento em que o estudante alcançar maturidade auditiva para ouvir corretamente e depois articular os fonemas e suas seqüências também corretamente (LADO, 1957). Desta forma o falante adulto adquire independência e autonomia lingüísticas para enfrentar qualquer situação de comunicação.

Entre os vocábulos eight paper, hot coffee, podemos observar em nossa amostra que todos os sujeitos que articularam o fonema / -t / final adicionando uma sílaba ao primeiro vocábulo, também notamos a interferência da língua materna. Por outro lado precisamos salientar que os fonemas ingleses plosivos / p btdkg / têm esse nome dada a característica explosiva, principalmente quando iniciam o vocábulo (O'CONNOR, 1980; ROACH, 1983). No caso das seqüências acima, seria correto e normal que os estudantes articulassem apenas um dos fonemas envolvidos. No caso da seqüência eight paper, esta poderia ser produzida como / ei lpeipər /, sem a articulação do / -t / (Hewings \& Goldstein, 2000). Para tanto o professor deve orientar seus alunos que pode haver a simplificação da seqüência de fonemas desde que não se 
pareça com um erro gramatical e que esse aspecto difere de um falante para outro, então não pode ser considerada uma regra, mas sim uma possibilidade de articulação. É o caso da seqüência I don't know, na qual o falante pode ou não produzir a letra t, esta é uma opção. Assim o estudante aos poucos se aproxima da fala nativa da língua inglesa.

Quanto às seqüências light white, white wine, os erros dos sujeitos tiveram a ver com acréscimo de sílaba. Fato este que ocorreu poucas vezes, mas que não podemos deixar de observar.

Ainda sobre as seqüências anteriores, há um aspecto que pode ser discutido do ponto de vista da seqüência de fonemas e vocábulos envolvidos. Há no texto a seqüência light white wine. O supostamente correto seria montar os fonemas finais / -t /, para light e white, mas não articulá-los, fazendo a juntura dos vocábulos (unreleased sounds), aspecto que ocorre freqüentemente na fala fluente dos nativos. O ouvinte reconhece a seqüência de vocábulos não somente pelo contexto, mas também porque ouve o que o falante produziu, articulando o fonema inicial do vocábulo seguinte. Ou ainda poderia juntar o fonema final / -t / com a semivogal seguinte (CELCE-MurCiA, 1991). Entretanto, alguns dos sujeitos produziram os três fonemas consonantais finais dos vocábulos em questão com o acréscimo de uma vogal epentética, um 'i’. Esse tipo de padrão silábico criado pelo falante da língua portuguesa pode ser justificado também com a interferência da língua materna para a produção dos fonemas, uma vez que o ambiente fonológico dos vocábulos favorece a adição de uma vogal pelos falantes do português. 
As seqüências de vocábulos of green, of mixed, of large, of hot, of corn, of bananas, of the, of light, of brown, of Dutch no ato da leitura efetuada pelos sujeitos houve a interferência do vocábulo escrito (STEINBERG, 1985 e 2006). O estudante ao ler o texto, produziu o fonema / - $f$ / ao invés do / - $\mathrm{v} /$ que é o correto. A princípio esse tipo de erro pode causar ao falante nativo uma certa estranheza, que pode gerar uma dúvida quanto à competência lingüística do aprendiz.

Ao elencarmos a seqüência de vocábulos kilos of, entendemos que o falante do português não utilizou o recurso de sua própria língua materna para articular a seqüência de fonemas, pois não produziu a letra $-\mathbf{s}$ com fonema de ' $z$ ' para poder unir os vocábulos, tornando assim a articulação da seqüência muito mais difícil de ser produzida (Schumaker, White \& Zanettinı, 2002). Acreditamos que nesse caso o sujeito foi influenciado pela grafia do vocábulo, articulou a letra -s com o fonema diretamente correspondente, o de / -s /.

Nas seqüências cheese cut e these few, os sujeitos adicionaram uma sílaba antes do vocábulo seguinte. Mais uma vez no momento da leitura os sujeitos articularam a letra -e, utilizando um recurso de sua língua materna (Schumaker, White \& ZANetTINI, 2002).

As seqüências de vocábulos seguintes possuem um fonema consonantal nasal final no primeiro vocábulo, ou / -m / ou / -n /: ham to, some butter, some first, some olive, some beer, some pears, some ham, ten red, thin...thanks, wine...a. Pudemos notar que quando esse fonema era o último do vocábulo, a consoante nasal foi articulada como uma vogal nasal do português, a 
língua materna dos sujeitos, que pode ser categorizado como um processo fonológico chamado nasalização (SILVEIRA, 1986). Enquanto que se o fonema consonantal nasal fosse seguido da letra -e que não pode ter produção na língua inglesa, os sujeitos de nossa pesquisa acrescentariam uma sílaba ao vocábulo. Enfim, em ambos os casos a interferência da língua materna foi observada nas ocorrências inadequadas.

Parece importante ressaltar que, embora o mesmo alfabeto latino seja utilizado por ambas as línguas envolvidas dessa pesquisa, sabemos que são dois sistemas lingüísticos diferentes, com um inventário fonético-fonológico também diferente e, assim não podemos deixar de mencionar que a grafia dos vocábulos ingleses, no momento da gravação da leitura, causou alterações relacionadas à interferência da língua materna na produção oral dos fonemas ingleses consonantais finais. Os sujeitos efetuaram a leitura do texto com base na correspondência utilizada em português, onde o fonema e a letra pela qual ele é representado apresentam identidade, o que obviamente acarretou em articulações inadequadas.

Refletindo sobre nossos dados, podemos notar que a $1^{\text {a }}$ gravação realizada pelos 45 sujeitos teve um maior número de erros, fato este que podemos justificar pela inexistência de treino antes da leitura do texto. Utilizando a mesma justificativa para os erros dos sujeitos para a $2^{\mathrm{a}}$ coleta, houve um número menor de vocábulos produzidos incorretamente, uma vez que houve a interferência da professora para o treino, resultando na leitura correta dos sujeitos para alguns dos vocábulos do texto, se a compararmos à coleta anterior. Cabe também lembrar que este aspecto referente às orientações da professora para o 
ensino da pronúncia e o treino são atividades práticas que tiveram como objetivo ajudar o estudante a atingir uma articulação dos fonemas consonantais mais próxima do falante nativo da língua inglesa.

Acreditamos que a descrição e a análise do ambiente da seqüência de vocábulos foi intensa, no entanto, enfatizamos que somente assim poderíamos justificar as ocorrências inadequadas e as categorias de erros encontradas em nossa amostra.

E, finalizando esse item, a interferência da língua materna para a leitura resultou na maioria das vezes no processo de adição de sílaba, os quais ocorreram repetidamente e se destacaram para as justificativas da seqüência de vocábulos do texto lido pelos sujeitos de nossa pesquisa.

\subsubsection{Importância do contraste das línguas envolvidas}

A princípio afirmamos, baseando-nos em autores como Godor, Gontow \& Marcelino (2006), Poedjosoedarmo (2004), Schumaker, White \& Zanettini (2002), Steinberg (1985 e 2006); que o conhecimento do inventário fonéticofonológico da língua-alvo é de grande ajuda para o entendimento dos estudantes na busca da produção correta de vocábulos desconhecidos. Embora saibamos que atualmente podemos ter acesso fácil à articulação de vocábulos por programas de computador, e são inúmeras as possibilidades, mesmo assim o estudante ainda pode recorrer ao dicionário para identificar e comparar vocábulos, desde que conheça e saiba produzir os fonemas da língua estrangeira.

Por esta razão, há de se atentar aqui para a necessidade de se conhecer o alfabeto fonético-fonológico da língua materna como podemos 
verificar na literatura, os autores Lado (1957), Harmer (1994), Poedjosoedarmo (2004) e Sснüтz (2004a). O professor, segundo nosso entendimento, deve apresentar os fonemas consonantais e vocálicos da língua-alvo, procurando sempre compará-los aos da língua materna, ou seja, o contraste fonéticofonológico das línguas envolvidas tem um papel fundamental para a aquisição da pronúncia da língua estrangeira (LADO, 1957). Não podemos perder de vista que o hábito do professor em comparar os fonemas de ambas as línguas envolvidas, ajuda o estudante a prestar maior atenção para o seu entendimento auditivo, o que o leva a obter melhoria para a produção dos fonemas também (O'ConNoR, 1980, Poedjoesoedarmo, 2004; Roach, 1983; Steinberg, 1985 e 2006). Quando o estudante recebe essas informações ele se instrumentaliza para tornar-se futuramente seu próprio orientador.

É preciso lembrar que deve haver treino para os fonemas diferentes ou aqueles que ocorrem em seqüências diferentes dos da língua materna, e conseqüentemente a importância em mostrar aos estudantes a possível inteligibilidade que ele poderá atingir, de acordo com seu nível de esforço e treino de suas dificuldades. Pois se os professores se preocuparem com as dificuldades de produção oral dos estudantes, haverá um resultado produtivo do ponto de vista da aprendizagem fonológica da língua estrangeira, uma vez que o estudante adquire uma compreensão mais clara das dificuldades fonológicas encontradas durante a aprendizagem da língua estrangeira.

Acrescentamos ainda que sem a ajuda do professor, o aluno não teria condições de adquirir a compreensão auditiva e produtiva dos problemas lingüísticos da língua-alvo. Isto significa que o professor tem um papel 
fundamental para aplicar seu conhecimento e ensiná-lo, ele deverá ser um diagnosticador de dificuldades e ajudar seus alunos realizando treinos para a solução necessária, mesmo que seja preciso apresentar materiais novos e atraentes sobre o mesmo tema, ao final o que interessa é que o estudante alcance a inteligibilidade. Por outro lado para que o estudante supere suas dificuldades de pronúncia da língua-alvo é imprescindível que haja uma conscientização do mesmo em perceber auditivamente e saber produzir os fonemas da maneira mais clara possível. Essa tarefa direcionada ao desenvolvimento dessas habilidades pode ser realizada com o auxílio do professor.

E é por isso que os pesquisadores da pronúncia da língua inglesa procuram identificar o que os alunos precisam ou não aprender, segundo experiências significativas que demonstram a superação das dificuldades de produção dos fonemas. Na verdade o tempo disponibilizado para os treinos e os exercícios que o estudante precisa realizar exige esforço, além disso, o estudante tem que lutar para pronunciar corretamente os fonemas diferentes de sua língua materna. Portanto, a recompensa por realizá-los é gratificante e compensadora.

$\mathrm{Na}$ medida em que os estudantes tomam conhecimento das semelhanças e das diferenças fonético-fonológicas, entre as línguas envolvidas, esse aspecto só tem a contribuir para criar a sua identidade oral. Vale lembrar que ao aprender o sistema fonológico da língua-alvo, o estudante irá assimilar os fonemas semelhantes por simples transferência, enquanto que por outro lado os fonemas que se estruturam de maneira diferente dos da língua nativa o seu aprendizado poderá ser mais lento e a dificuldade em produzi-los poderá demorar 
a ser superada (Lado, 1957; Mascherpe, 1970; Schumaker, White \& Zanettini, 2002). Essa atitude demonstrará que os estudantes têm a preocupação de uma fala inteligível e a compreensão da importância desse conhecimento. O professor sabendo do interesse dos alunos poderá trazer para a aula exercícios suplementares que tenham o conjunto das dificuldades que 0 falante do português tem ao aprender inglês, essa seria uma forma de corrigir os problemas e os estudantes ao exercitá-los, atingiria uma fala mais inteligível (HEWINGS, 2004).

Então, a partir dessa nossa afirmação temos a convicção de que oferecer aos estudantes a oportunidade de conhecer e treinar repetições dos fonemas da língua inglesa, utilizando materiais didáticos disponíveis no mercado com falantes nativos, esse tipo de conhecimento aliado aos materiais disponíveis na Internet ou mesmo em programas para serem utilizados no computador, traz ao estudante a possibilidade de aproveitar esse conhecimento para desenvolver e melhorar seu sotaque e desta forma tentar articular os vocábulos ingleses de uma maneira mais natural e que possa causar impacto positivo perante outros falantes, sejam eles nativos ou não (ScHütz, 2005).

Após a fase dos exercícios desenvolvidos em sala, há a necessidade de haver uma checagem para saber se o estudante aprendeu e internalizou sua dificuldades de articulação dos fonemas que são diferentes. Como o professor sabe quais são as dificuldades, facilita preparar uma avaliação oral para testá-las, dessa forma ele irá selecionar os problemas e poderá trabalhar com a comparação entre as línguas envolvidas, seja com frases ou vocábulos cuidadosamente escolhidos. Há muitas possibilidades que o professor deverá escolher cuidadosamente de forma que atinja seu objetivo na avaliação, 
ou seja, na comprovação de que os alunos saibam reconhecer e produzir suas dificuldades (LADO, 1957). No nosso caso, fizemos uma checagem preliminar, na qual foi possível identificar as dificuldades e no final do curso pudemos rever no mesmo texto se o aluno foi bem sucedido com relação à superação de seus problemas fonéticos e fonológicos.

Devemos ressaltar que a pronúncia padrão deve ser ensinada aos alunos, seja ela Americana ou Inglesa (Hewings, 2004; Medgres, 1994). Haverá uma aproximação da fala do nativo, porém nunca a perfeição será atingida. A fala do estrangeiro sempre carregará traços de articulação de sua língua materna (LADO, 1957).

Por outro lado, se considerarmos que o estudante poderá dispor da possibilidade de morar no exterior, esse aspecto faz com que o nível de produção da língua estrangeira que o estudante pode alcançar seja bastante significativo para seu desenvolvimento fonético-fonológico. Uma vez que durante todo o tempo ele estará ouvindo e tentando reproduzir a fala dos nativos no seu dia-a-dia.

Enfim, quanto ao ensino-aprendizagem do inglês como língua estrangeira, podemos identificar que para o estudante ser bem sucedido durante a comunicação, fatores como a motivação, a situação instrucional ou acadêmica, as atitudes que são tomadas perante a sociedade, se ele é introvertido ou extrovertido, bem como ansiedade e empatia, são fatores relevantes para sua aceitabilidade no grupo (HARmeR, 1994; Schütz, 2003b). De forma geral podemos considerar que mesmo quando nossa articulação se aproxima da fala do nativo, provavelmente haverá um leve sotaque estrangeiro com características fonéticas 
de nossa língua materna. E os professores devem considerar essa variação normal, pois apresenta a identidade social e individual do estudante.

\subsubsection{Inteligibilidade}

Uma vez que a opacidade da língua inglesa pode resultar em inúmeras produções errôneas de vocábulos pelos falantes do português do Brasil, segundo a distinção que há entre as línguas, essas dificuldades relacionadas a produção dos fonemas poderão ser sanadas se forem realizados exercícios orais adequados com os alunos.

O professor deve incentivar e conscientizar seus alunos sobre tornarem-se inteligíveis, deve apontar para o fato de que o estudante deve partir da fala do nativo para atingir seu próprio desenvolvimento e aproximação dessa fala.

Nas aulas de língua inglesa ao serem realizadas repetições identificando as semelhanças e diferenças entre as línguas envolvidas, não significa que os estudantes alcançarão uma produção como a do falante nativo. A variedade de exercícios tende a contribuir para a melhoria da percepção e da articulação dos vocábulos ingleses, sem significar uma produção idêntica aos falantes nativos, como afirmam Celce-Murcia (1991) e Cristófaro-Silva (2006). Ao atingi-la, essa ajuda o estudante a ser reconhecido como um falante competente. O falante nativo perceberá que a "fala do estrangeiro" possui características fonético-fonológicas bem trabalhadas e que podem perfeitamente identificar que ele se esforçou para atingir uma pronúncia inteligível (WALKER, 2001). Assim o falante estrangeiro pode ser aceito no que diz respeito a sua habilidade 
comunicativa. Por isso, concordamos com Kenworthy (1990) e Schumaker, White \& ZANETTINI (2002) quando afirmam que o aluno terá que se dedicar a ouvir e a produzir inúmeras vezes os fonemas produzidos por um falante nativo, até conseguir pronunciá-los corretamente sempre que quiser alcançar um nível suficiente de inteligibilidade.

Mas se observarmos a afirmação anterior sobre outro aspecto, o do ouvinte, do falante nativo, ele pode ter uma atitude de aceitabilidade e tolerância para com a fala do não-nativo, como afirma DALTON \& SEIDLHOfER (1994), uma vez que a fala pode depender de fatores como, por exemplo, da ocasião em que a comunicação está ocorrendo, os respectivos papéis que envolvem os falantes e seu respectivo status na sociedade. Esses aspectos podem ter um significado peculiar porque a comunicação pode resultar num fenômeno que pode ser identificado como 'inteligibilidade não recíproca'.

Uma implicação que nos parece positiva se coloca em o falante do português ser aceito perante os da língua inglesa, significa ser aceito também socialmente. E, no contexto sociolingüístico podemos afirmar que o falante do português deverá fazer ajustes em suas falas, reconhecendo suas limitações e deficiências para a articulação dos vocábulos. Não podemos nos esquecer que nossa própria experiência como ouvintes nos ensinam como devemos ou não proceder em determinadas situações, uma vez que ao falarmos estamos sujeitos a sofrer severos julgamentos relacionados a nossa origem, qual a classe social a que pertencemos, nosso nível educacional e até mesmo se somos uma pessoa agradável para o ouvinte ou não (LABOV, 1972). Todos esses aspectos aqui descritos são evidências de que a fala agrega a identidade individual, tornando-se 
um fator importantíssimo para nos colocarmos neste complexo sistema social em que vivemos.

Portanto, devemos ter em mente que cada pessoa é um indivíduo, que tem intenção de estabelecer sua identidade, por meio de um papel social pré-determinado de interação, isto é, não podemos perder de vista que fazemos parte de um grupo, de uma sociedade. Assim, tudo o que fazemos ou dizemos para nos comunicar está diretamente relacionado tanto ao aspecto consciente como ao inconsciente, seja em nossa língua materna ou estrangeira. 
Considerações Finais 
Tivemos como objetivo geral da pesquisa demonstrar e analisar as dificuldades em produzir os fonemas consonantais finais dos vocábulos ingleses, durante a aprendizagem dos falantes brasileiros, estudantes do curso de Tradutor de uma universidade privada da cidade de São Paulo.

Na primeira coleta, realizada antes do treino notamos que houve mais erros em VC (38\%) do que em CVC (15\%) com predomínio de 28 vocábulos. Para VC os vocábulos com mais produções inadequadas foram: of, oil. Enquanto para CVC os vocábulos são: foil, useful, ham, whole, sole. Em relação às categorias de erros verificamos que Adição ou Acréscimo, seguida pela Substituição ou Transferência, e por Vocalização ocorreu mais que Omissão ou Apagamento e Nasalização, respectivamente.

Na segunda coleta, realizada após o treino notamos que houve uma superação das dificuldades de produção totalizando 19 vocábulos. Em VC (16\%) os vocábulos como of e oil se repetiram e em CVC (7\%) tivemos a maior ocorrência de useful, ham, whole. Ao observarmos as categorias de erros notamos que Adição ou Acréscimo seguida de Vocalização ocorreram mais que Substituição ou Transferência, Nasalização e Omissão ou Apagamento.

Embora em números absolutos o padrão silábico CVC seja maior, a análise estatística foi fundamental para mostrar-nos que proporcionalmente o padrão VC ocorreu mais.

Ao compararmos as duas coletas verificamos a ocorrência repetida de vocábulos em mais de uma categoria de erros, por mais de um sujeito, resultando num total de 43 vocábulos, assim distribuídos: 180 ocorrências 
inadequadas de VC e 720 de CVC para a categoria de Adição ou Acréscimo; apenas 135 ocorrências de CVC para Nasalização; também apenas 180 de CVC para Omissão ou Apagamento; 45 de VC e 225 de CVC para Substituição ou Transferência; e, 45 de VC e 180 de CVC para Vocalização. Podemos afirmar que a maioria deles teve sua produção inadequada em ambas às coletas.

Para a categoria Adição e Acréscimo, VC e CVC tiveram doze vocábulos que ocorreram em ambas as coletas, em oposição a seis vocábulos na $1^{\mathrm{a}}$ coleta e apenas um na $2^{\mathrm{a}}$. Para Nasalização, os três vocábulos ocorreram em ambas às coletas. Enquanto para Omissão e Apagamento, um ocorreu nas duas coletas e três somente na $1^{\text {a }}$. Já para Substituição ou Transferência, três vocábulos ocorreram tanto nas duas coletas como apenas na $1^{\mathrm{a}}$. Finalmente, para Vocalização tivemos três ocorrências nas duas coletas e duas para a $1^{\text {a }}$.

Assim ao comparamos as duas coletas da amostra, verificamos que os erros dos sujeitos relacionaram-se também ao vocábulo seguinte, de forma que os estudantes utilizaram estratégias fonético-fonológicas de sua língua materna para articular os vocábulos consecutivos da língua estrangeira.

$\mathrm{Na}$ tentativa de encontrar respostas para o desempenho dos alunos durante as coletas tentamos verificar uma possível correlação entre as perguntas de 23 a 26 do questionário aplicado e as categorias de erros identificadas em nossa amostra. Em nossa pesquisa detectamos que os estudantes acreditam que a habilidade de 'ler' silenciosamente é mais fácil; que por outro lado à habilidade de 'falar' é a mais difícil; e que a pronúncia adequada é imprescindível para a profissão de intérprete. Com base nas respostas dos alunos podemos afirmar que ao realizarmos nossa coleta de dados lidamos com a 
habilidade lingüística de mais difícil aquisição. Mas que por outro lado pudemos também reconhecer que se o estudante for treinado, ele é capaz de superar a maioria das suas dificuldades. Acreditamos que o tempo entre uma gravação e outra não foi suficiente para que o sujeito alcançasse uma pronúncia realmente inteligível. Portanto, em nenhum momento intencionamos interpretar ou mesmo justificar o nível de proficiência dos sujeitos, com base em suas dificuldades.

Acreditamos que essa pesquisa pode contribuir para o falante do português, no que diz respeito ao ensino-aprendizagem do inglês como língua estrangeira. No corpo do trabalho descrevemos minuciosamente as dificuldades fonéticas e fonológicas das consoantes inglesas em final de vocábulo. Essas informações devem direcionar tanto o professor como o aluno a atingir uma pronúncia mais inteligível. Caberá ao professor guiar o aluno para a superação dos problemas de articulação. E caberá ao aluno buscar uma série de treinos orais focados em suas dificuldades de produção.

Fica aqui registrada a intenção de, num outro momento, podermos considerar a possibilidade de projeção dessa pesquisa ao analisarmos os dados do ponto de vista sociolingüístico, pois sabemos que há outras possibilidades para se analisar os dados a partir do questionário, tais como considerar para análise e discussão dados da faixa etária, do gênero dos sujeitos, entre outros. 
REFERÊNCIAS 


\section{Referências Bibliográficas}

Alten, W.S. Living English Speech. London: Longman, 1978.

Altwright, Dick; Bailey, Kathleen M. Focus on the Language Classroom. An introduction to classroom research for language teachers. Cambridge, New York: Cambridge University Press, 1991.

Almeida Filho, José Carlos Paes de. Dimensões Comunicativas no Ensino de Línguas. Campinas: Pontes, 1993.

Azevedo, Milton M. Contrastive Phonology of Portuguese and English. p. 113. Tese (Doutorado em Lingüística). Georgetown University Press, Washington D.C., 1981.

BARber, Charles. The English Language: a historical introduction. Cambridge/New York: Cambridge University Press, 1993.

Baker, Ann; Goldstein, Sharon. Pronunciation Pairs. Cambridge/New York: Cambridge University Press, 1990.

Bısol, Leda (org.). Introdução a Estudos de Fonologia do Português Brasileiro. 3. ed. Porto Alegre: EDIPUCRS, 2001.

Bohn, Hilário Inácio; Vandresen, Paulino. Tópicos de Lingüística Aplicada: o ensino de línguas estrangeiras. Florianópolis: UFSC, 1988.

Bowerman, Melissa; Levinson, Stephen C. (ed.). Language Acquisition and Conceptual Development. Cambridge: Cambridge University Press, 2000, p. 805820. 
Caglari, Gladis M.; Cagliarl, Luiz Carlos. "Fonética". In: Mussalin, Fernanda; Bentes, Anna Christina (org.). Introdução à Lingüística 1: domínios e fronteiras. São Paulo: Cortez, 2000, p.105-146.

Callou, Dinah; Leite, Yonne. Iniciação à Fonética e à Fonologia. 4a. ed. Rio de Janeiro: Jorge Zahar, 1995.

CÂmara JR, Joaquim. Estrutura da Língua Portuguesa. Petrópolis: Vozes, 1970. . Problemas da Lingüística Descritiva. Petrópolis: Vozes, 1971. . Princípios de Lingüística Geral. $4^{\text {a }}$. ed. Rio de Janeiro: Acadêmica, 1972. . Para o Estudo da Fonêmica Portuguesa. Rio de Janeiro: Padrão, 1977.

Catton, Julie C. A Pilot Study on a Holistic Model Incorporating a Psycholinguistic Approach Accelerating Second Language Acquisition. San Raphael: Dominican University of Califórnia, 2006.

Caronı, Lilia. "Aquisição de Segunda Língua: a teoria de Krashen". In: Bohn, H. I. \& VAndREsen, P. Tópicos em Lingüística Aplicada: o ensino de línguas estrangeiras. Florianópolis: Ed. da Universidade Federal de Santa Catarina, 1988, p. 50-74.

Celce-Murcia, Marianne. Teaching English as a Second Foreign Language. Massachusetts: Heinle \& Heinle Publishers, 1991.

; Goodwin, Janet M. "Teaching Pronunciation". In: Celce-Murcia, Marianne. Teaching English as a Second Foreign Language. Massachusetts: Heinle \& Heinle Publishers, 1991.

Coseriu, E. Teoria da Linguagem e Lingüística Geral. Rio de Janeiro / São Paulo: Presença / EDUSP, 1979. 
Cristófaro-Silva, Thaïs. "Palatalisation in Brazilian Portuguese". In: Living on the Edge: 28 Papers Honour of Jonathan Kaye. Studies in Generative Grammar 62. Stefan Ploch (ed.) ISBN 3-11-017619-X. Mouton de Gruyter Berlin - New York, 2003, p. 243-257.

. Exercícios de Fonética e Fonologia. São Paulo: Contexto, 2003.

. Fonética e Fonologia do Português. $6^{\text {a }}$. ed. São Paulo: Contexto, 2002.

; Martins, Raquel Fontes. "O Cancelamento de Líquidas em Posição Intervocálica”. In: César Reis (org.). Estudo em Fonética e Fonologia do Português. Minas Gerais: FALE-UFMG, 2002.

CRYSTAL, David. The Cambridge Encyclopedia of Language. Cambridge, New York: Cambridge University Press, 1987.

Chomsky, Noam; Halle, Morris. The Sound Pattern of English. Cambridge, MA: MIT Press, 1995.

Dale, Paulette; Poms, Lillian. English Pronunciation Vowels: for Spanish speakers. New Jersey: Prentice Hall, 1985.

. English Pronunciation Consonants: for Spanish speakers. New Jersey: Prentice Hall, 1986.

. English Pronunciation: made simple. 2 audio CDs. New York: Longman, 2005.

Dalton, Cristiane; Seidlhofer, Barbara. Pronunciation. New York/ Oxford: Oxford University Press, 1994.

Dictionary of English Language and Culture. Essex: Longman, 1992.

Duвoıs, Jean et all. Dicionário de Lingüística. Sao Paulo: Cultrix, 1973. 
EluIs, Rod. Second Language Acquisition. Oxford, New York: Oxford University Press, 1997.

FARrel, Thomas S.C. Planejamento de Atividades de Leitura para Aulas de Idiomas. Portfólio SBS 6. Tradução de Itana Summers Medrado. São Paulo: Special Book Services, 2003.

Fernandes, Paulo R. C. A Epêntese Vocálica na Interfonologia Português/Inglês. Dissertação (Mestrado em Letras), Universidade Católica de Pelotas, Pelotas, 1997.

Ferreira Netto, Waldemar. Introdução a Fonologia da Língua Portuguesa. São Paulo: Hedra, 2001.

FıoRIN, José Luiz (org.). Introdução à Lingüística II: princípios de análise. São Paulo: Contexto, 2003.

FontAine, Jacqueline. O Círculo Lingüístico de Praga. São Paulo: Cultrix, 1978.

FrançA, Ângela. "Dois Momentos no Problema da Pronúncia Padrão Brasileira (1937-1956)". In: VI Seminário do Projeto Para a Historia do Português Brasileiro. Itaparica - Bahia, de 29 de agosto a 02 de setembro de 2004.

Gass, S. M.; Selinker, L. Second Language Acquisition: an introductory course. 2. ed. Athens: Ohio University, 2001.

Gilbert, Judy B. Clear Speech. Pronunciation and listening Comprehension in North American English. 2a . ed. Cambridge/New York: Cambridge University Press, 1993.

Gimson, A. C. An Introduction to the Pronunciation of English. London: Edward Arnold, 1962. 
Gleason JR., H. A. Introdução à Lingüística Descritiva. Tradução de João Pinguelo. $2^{a}$. ed. Lisboa: Fundação Calouste Gulbenkian, 1961.

Godoy, Sonia M.B.; Gontow, Cris; Marcelino, Marcelo. English Pronunciation for Brazilians: the sounds of American English. São Paulo: Disal, 2006.

Grabe, W.; Kaplan, R. Introduction to Applied Linguistics. New York: AddisonWesley, 1992.

Hadley, Gregory. Pesquisa de Ação em Sala de Aula. Portfólio SBS 8. Tradução de Rinaldo Silveira. São Paulo: Special Book Services, 2004.

HARMer, Jeremy. The Practice of English Language Teaching. New edition. New York: Longman, 1994.

Haverson, Wayne W. "Adult Literacy Training". In: Celce-Murcia, Marianne. Teaching English as a Second Foreign Language. Massachusetts: Heinle \& Heinle Publishers, 1991.

Hewings, Martin. Pronunciation Practice Activities - a resource book for teaching English pronunciation. New York, Cambridge: Cambridge University Press, 2004.

; Goldstein, Sharon. Pronunciation Plus - practice through interaction. New York, Cambridge: Cambridge University Press, 2000.

Huelmslev, I. Prolegômeros a uma Teoria da Linguagem. Tradução de J. Teixeira Coelho Neto. São Paulo: Perspectiva, 1975.

Holden, Susan; Rofers, Mickey. O Ensino da Língua Inglesa. 2 a. ed. (revisada). São Paulo: Special Book Services, 2002.

Hornby, A. S. Oxford Advanced Learner's Dictionary of Current English. 3. ed. Oxford/New York: Oxford University Press, 1974. 
Houals, Antonio; Villar, Mauro Salles. Dicionário Houais da Língua Portuguesa. 1. ed. Rio de Janeiro: Objetiva, 2001.

loup, G. "Is there a structural foreign accent? A comparison of syntactic and phonological errors in second language acquisition". In: Language Learning. Vol. $34, n^{\circ} 2,1984$, Junho, 01-17.

Izarra, Laura P.Z.; Di Candia, Michela Rosa (org.), Ensino de Língua Inglesa Através do Texto Literário. São Paulo: Humanitas, 2007.

Jakobson, Roman. Lingüística e Comunicação. Tradução de Isidoro Blinkstein e Jose Paulo Paes. São Paulo: Cultrix, 1969.

. Fonema e Fonologia: ensaios. Rio de Janeiro: Acadêmica, 1972.

JenkINs, J. "The Phonology of English as an International Language". In: BrazTesol Newsletter. Sao Paulo, p.12, March, 2005.

Jones, Daniel. English Pronouncing Dictionary. $15^{\text {th }}$ edition. Cambridge, New York: Cambridge University Press, 1997.

Jubran, Safa Abou Chahla. Árabe e Português: Fonologia Contrastiva. São Paulo: Editora da Universidade de São Paulo/ Fapesp/CEAR, 2004.

Kenstowicz, Michael. Phonology in Generative Grammar. Oxford: Blackwell, 1994.

Kenworthy, Joanne. Teaching English Pronunciation. New York: Longman, 1990.

KHAN, L M. L. "A review of 16 major phonological processes". In: Language Speech and Hearing Services in Schools, 1982, p. 77-85.

KLEIN, Wolfgang. Second Language Acquisition. Cambridge, New York: Cambridge University Press, 1986. 
Krashen, Stephen D. Principles and Practice in Second Language Acquisition. New York: Prentice Hall, 1987.

. Second Language Acquisition and Second Language Learning. New York: Prentice Hall, 1988.

Labov, William. Sociolinguistic Patterns. Philadelphia, PA: University of Pennsylvania Press, 1972.

LADO, Robert. Linguistics Across Cultures. Ann Harbor, Michigan: University of Michigan, 1957.

. "Linguistics and Foreign Language Teaching". In: Language Learning, special issue, $n^{\circ} 2,1961$, p. 29-41.

Leffa, Vilson J. "Metodologia do Ensino de Línguas". In: Bohn, H. I. \& Vandresen, P. Tópicos em Lingüística Aplicada: o ensino de línguas estrangeiras. Florianópolis: Ed. da Universidade Federal de Santa Catarina, 1988, p. 211-236.

Lepschy, Giulio C. A Lingüística Estrutural. 2. ed. São Paulo: Perspectiva,1975.

LoPES, Edward. Fundamentos da Lingüística Contemporânea. São Paulo: Cultrix, 1991.

Longman Dictionary of English Language and Culture. With colour illustrations. Essex: Longman, 1992.

Longman Handy Learner's Dictionary of American English. Hong Kong: Longman, 1993.

MacMillan Essential Dictionary: for learners of American English. With CD-ROM. London: MacMillan Education, 2003. 
Malmberg, Bertil. As Novas Tendências da Lingüística. São Paulo: Companhia Editora Nacional, 1974.

MARTIN, M.H.C. Exercising Spoken English. London: MacMillan Education Ltd, 1970.

Martinet, André. Elementos de Lingüística Geral. Tradução de Jorge MoraisBarbosa. Lisboa: Sá da Costa, 1964.

A Lingüística Sincrônica. Tradução de Lílian Arantes. Rio de Janeiro: Tempo Brasileiro, 1971.

Mascherpe, Mário. Análise Comparativa dos Sistemas Fonológicos do Inglês e do Português. p. 156. Tese (Doutorado em Lingüística), EGTR, Assis, São Paulo, 1970.

Medgyes, P. The Non-Native Teacher. London: MacMillan, 1994.

Morettin, Luiz Gonzaga. Estatística Aplicada - Volume 2 - Inferência. São Paulo: Makron Books, 2000.

Morı, Angel C. "Fonologia”. In: Mussalin, Fernanda; Bentes, Anna Christina (org.). Introdução à Lingüística 1: domínios e fronteiras. São Paulo: Cortez, 2000, p.147180.

Mortimer, Colin. Elements of Pronunciation. Intensive practice for intermediate and more advanced students. Cambridge/New York: Cambridge University Press, 1985.

Mussalin, Fernanda; Bentes, Anna Christina (org.). Introdução à Lingüística 1: domínios e fronteiras. São Paulo: Cortez, 2000.

Nunan, David. Research Methods in Language Learning. Cambridge, New York: Cambridge University Press, 1992. 
. Second Language Teaching and Learning. Boston: Heinle \& Heinle Publishers, 1999.

O'Connor, J. D. Better English Pronunciation. 2a . ed. Cambridge, New York: Cambridge University Press, 1980.

OdLIN, Terence. Language Transfer. Cambridge, New York: Cambridge University Press, 1989.

OrION, Gertrude F. Pronouncing American English: sounds, stress, and intonation. $2^{\text {a }}$. ed. New York: Heinle \& Heinle Publishers, 1997.

Palomo, Sandra Maria Silva. Análise Contrastiva do Sistema Fonológico do Armênio e do Português: implicações pedagógicas. p. 392. Tese (Doutorado em Semiótica e Lingüística Geral), Faculdade de Filosofia, Ciências e Letras da Universidade de São Paulo, São Paulo, 1989.

Poedjosoedarmo, Gloria. O Ensino da Pronúncia: por quê, o quê, quando e como. Portfólio SBS 9. São Paulo: Special Book Services, 2004.

Richards, Jack C. The Context of Language Teaching. Cambridge, New York: Cambridge University Press, 1985.

O Ensino Comunicativo de Línguas Estrangeiras. Portfólio SBS 13. Tradução de Rosana S.R. Cruz Gouveia. São Paulo: Special Book Services, 2006.

; Platt, John; Platt, Heidi. Dictionary of Language Teaching \& Applied Linguistics. New Edition. Essex: Longman, 1995.

Riggenbach, Heidi; Lazaraton, Anne W. "Promoting Oral Communication Skills". In: Celce-Murcia, Marianne. Teaching English as a Second Foreign Language. Massachusetts: Heinle \& Heinle Publishers, 1991. 
RoACH, Peter. English Phonetics and Phonology. Cambridge, New York: Cambridge University Press, 1983.

Rogerson, Pamela; Gilbert, Judy B. Speaking Clearly - pronunciation and listening comprehension for learners of English. Cambridge, New York: Cambridge University Press, 1990.

Rubin, Joan; Thompson, Irene. How to be a More Successful Language Learner. 2a . ed. Massachusetts: Heinle \& Heinle Publishers, 2001.

Sant'Anna, Magali Rosa de. "A Interferência da Língua Materna e o Acréscimo da Vogal Epentética na Língua-Alvo". In: Fromm, Guilherme \& LimA-Hernandes, Maria Célia. Domínios da Linguagem V: diálogo entre a universidade, a escola e a sociedade. São Paulo: Plêiade, 2005, p. 197-220.

"A Sonoridade do TH na Língua Inglesa: um estudo de caso". In: FRomm, Guilherme \& Lima-HeRnandes, Maria Célia. Domínios da Linguagem IV: subsídios à formação lingüística. São Paulo: Yangraf Gráfica, 2004, p. 87-104.

. "As Interferências Fonológicas no Inglês como Língua Estrangeira para os Falantes do Português do Brasil”. In: Dialogia. Revista do Departamento de Educação do Centro Universitário Nove de Julho - UNINOVE. São Paulo: UNINOVE, v. 2, 2003, p. 57-70.

- Língua Inglesa como Língua Estrangeira no $3^{\circ}$ Grau: um estudo de desvios fonológicos. p. 183. Dissertação (Mestrado em Semiótica e Lingüística Geral) - Faculdade de Filosofia, Letras e Ciências Humanas da Universidade de São Paulo, São Paulo, 1997.

Saussure, Ferdinand de. Curso de Lingüística Geral. São Paulo: Cultrix, 1979.

Schumaker, C.; White, P.L.; Zanettini, M. Guia de Pronúncia do Inglês para Brasileiros. With CD-ROM. Rio de Janeiro: Campus, 2002. 
SilveIRA, Regina Célia Pagliucci de. Estudos de Fonologia Portuguesa. São Paulo: Cortez, 1986.

. Estudos de Fonética do Idioma Português. São Paulo: Cortez, 1988.

Slama-Cazacu, Tatiana. Psicolingüística Aplicada ao Ensino de Línguas. São Paulo: Pioneira, 1979.

Steinberg, Martha. Pronúncia do Inglês Norte-Americano. Série Princípios. São Paulo: Ática, 1985.

- Inglês Norte-Americano Pronúncia e Morfologia. São Paulo: Nova Alexandria, 2006.

Titone, Renzo. Psicolingüística Aplicada: introdução psicológica à didática das línguas. São Paulo: Summus, 1983.

Troubetzkóy, N.S. Príncipes de Fonologia. Paris: Klincksieck, 1961.

WALKER, Robin. "Pronunciation for International Intelligibility". In: English Teaching Professional, Issue 21, October 2001.

WaRdHAUGH, Ronald. Introduction to Linguistics. New York: McGraw-Hill, 1972.

Widdowson, H. G. Teaching English as Communication. Oxford/New York: Oxford University Press, 1978.

. Explorations in Applied Linguistics. Oxford: Oxford University Press, 1985. 


\section{Webgrafia}

Accent Tutor on Line. Disponível em

<http://www.speechcom.com/contest/contest.html>. Acesso em: 20 jun. 2005.

Bond, K. "Pronunciation Problems for Brazilian Students of English". In: Karen's Linguistics Issues. August, 2001. Disponível em

$<$ http://www3.telus.net/linguisticsissues/pronunciation.html>. Acesso em: 20 jun. 2005.

Cook, Vivian. "Acquisition in Phonology". In: Second Language

Acquisition Topics. Disponível em

<http://homepage.ntlworld.com/vivian.c/SLA/sla_phonology.html>. Acesso em 20 jun. 2005.

Cristófaro-Silva, Thaïs. "O Ensino de Pronúncia na Aula de Língua Estrangeira". 2006. Disponível em www.letras.ufmg.br/cristofaro. Acesso em: 25 ago. 2006.

. "On Phonological Generalizations and Sound Change". In: $10^{\text {th }}$ Manchester Phonology Meeting, 2002. Manchester. Disponível em www.letras.ufmg.br/cristofaro. Acesso em: 25 ago. 2006.

; OlIVEIRA, Marco Antônio. "Lateral Vocalization in Brazilian Portuguese". Paper presented at the $3^{\text {rd }}$ UKLVC-University of York - England - July 2001. Disponível em www.letras.ufmg.br/cristofaro. Acesso em: 25 ago. 2006.

Hashemian, Mahmood; Nezhad, Mohammed R. T. "The Development of Conceptual Fluency \& Metaphorical Competence in L2 Learners". In: Linguistik on Line 30, 1/07. Disponível em <http://www.linguistikonline.de/30_07/hashemianNezhad.htm>. Acesso em; 18 jul. 2007. 
Roseberry-McKibbin, Celeste; Brice, Alejandro. "Acquiring English as a Second Language". (s.d.) Disponível em

<http://www.asha.org/public/speech/development/easl.htm>. Acesso em: 16 out. 2005.

Sснӥтz, Ricardo. "O que Significa Aprender Inglês". 2007. Disponível em English Made in Brazil <http://www.sk.com.br/sk-conso.html>. Acesso em: 31 out. 2007. . "Aquisition and Learning". 2006. Disponível em English Made in Brazil <http://www.sk.com.br/sk-conso.html>. Acesso em: 17 nov. 2006.

. "As Consoantes do Inglês e do Português". 2005. Disponível em English Made in Brazil <http://www.sk.com.br/sk-conso.html>. Acesso em: 12 dez. 2005. _. "Assimilação Natural X Estudo Formal". 2004a. Disponível em English Made in Brazil <http://www.sk.com.br/sk-lax11.html>. Acesso em: 22 jan. 2004. . "A Correlação Ortografia x Pronúncia". Disponível em English Made in Brazil <http://www.sk.com.br/sk-interfer.html>. 2004b. Acesso em: 12 jun. 2004. . "Communicative Approach - Abordagem Comunicativa". 2003a.

Disponível em English Made in Brazil <http://www.sk.com.br/sk-comm.html>. Acesso em: 26 jul. 2003.

. "Motivação e Desmotivação no Aprendizado de Línguas". 2003b. Disponível em English Made in Brazil < http://www.sk.com.br/sk-motiv.html>. Acesso em: 10 nov. 2003. 
Anexos

(vide CD Rom) 


\section{Anexo A - Texto}

Texto utilizado para a gravação da pronúncia dos sujeitos dessa pesquisa:

If you're going shopping, John,

Could you get me these few things, please?

Three kilos of green beans,

Six tins of mixed pickles,

Ten red or yellow peppers,

A bag of apples,

Half a carton of large tomatoes,

A pot of hot coffee,

Four sorts of corn,

A cookery book,

A bunch of bananas and some butter,

Two tubes of the useful new glue,

Some first early potatoes,

Eight paper plates,

A whole Dover sole,

Five kinds of light white wine,

A pound of brown flour,

Some olive oil and cooking foil,

Some beer, not too dear,

Some pears to share,

Some ham to cure, if you're sure it's pure,

And a measure of orange juice,

And a chunk of Dutch cheese cut thick or thin.

Thanks very much, John.

(Autor desconhecido) 


\section{Anexo B - Vocábulos do texto com a transcrição da(s) pronúncia(s) correta(s)}

\begin{tabular}{|c|c|}
\hline Vocábulo & Transcrição \\
\hline$a$ & eI (strong form) - $\boldsymbol{\partial}$ (weak form) \\
\hline and & $\begin{array}{l}\text { ænd (strong form) - ənd, ən, nd, } n \text { (weak } \\
\text { forms) }\end{array}$ \\
\hline apples & 'æplz \\
\hline bag & bæg \\
\hline bananas & bə'nænəz (AmE) - bə'na:nəz (BrE) \\
\hline beans & bi:nz \\
\hline beer & bIr (AmE) - bIər (BrE) \\
\hline book & buk \\
\hline brown & braun \\
\hline bunch & b^nt \\
\hline butter & 'bAtre (AmE) - 'bAtər (BrE) \\
\hline carton & 'ka:rt'n (AmE) - 'ka:tən (BrE) \\
\hline cheese & t $\int i: z$ \\
\hline chunk & tfAnk \\
\hline coffee & 'ka:fI , 'ko:fI (AmE) - 'kbfI (BrE) \\
\hline cookery & 'kuk'ri \\
\hline cooking & 'kukın \\
\hline corn & ko:rn (AmE) - ko:n (BrE) \\
\hline
\end{tabular}

\begin{tabular}{|l|l|}
\hline \multicolumn{1}{|c|}{ Vocábulo } & \multicolumn{1}{c|}{ Transcrição } \\
\hline glue & glu: \\
\hline going & gouIn (AmE) - gəuIn (BrE) \\
\hline green & grian \\
\hline half & hæf (AmE) - ha:f (BrE) \\
\hline ham & hæm \\
\hline hot & ha:t (AmE) - hnt (BrE) \\
\hline if & If \\
\hline it's & Its \\
\hline John & d3a:n (AmE) - d3bn (BrE) \\
\hline juice & d3u:s \\
\hline kilos & 'ki:louz (AmE) - 'ki:ləuz (BrE) \\
\hline kinds & kaIndz \\
\hline large & la:rd3 (AmE) - la:d3 (BrE) \\
\hline light & lart \\
\hline me & $\begin{array}{l}\text { mi: (normal form) - mI (frequent weak } \\
\text { form) }\end{array}$ \\
\hline measure & Imezวr (AmE) - 'mezər (BrE) \\
\hline mixed & mikst \\
\hline much & m^t \\
\hline
\end{tabular}

\begin{tabular}{|c|c|}
\hline Vocábulo & Transcrição \\
\hline potatoes & pə'tertouz (AmE) - pə'tertəuz (BrE) \\
\hline pound & paund \\
\hline pure & pjur (AmE) - pjuər, pjo: (BrE) \\
\hline red & red \\
\hline share & $\int e r(A m E)-\int e e^{r}(B r E)$ \\
\hline shopping & 'Ja:pIn (AmE) - 'SppIn (BrE) \\
\hline six & siks \\
\hline sole & soul (AmE) - səul (BrE) \\
\hline some & /s^m/ (strong form) $-/ \mathbf{s} ə \mathrm{~m} /$ (weak form) \\
\hline sorts & so:rts (AmE) - so:rts (BrE) \\
\hline sure & 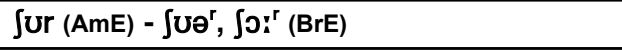 \\
\hline ten & ten \\
\hline thanks & $\theta æ j k s$ \\
\hline the & $\begin{array}{l}\begin{array}{l}\text { бi: (strong form) } / / \text { (weak forms): } \\
\text { consonants) }\end{array} \\
\end{array}$ \\
\hline these & бi:z \\
\hline thick & OIk \\
\hline thin & $\theta$ In \\
\hline things & $\theta$ Inz \\
\hline
\end{tabular}




\begin{tabular}{|c|c|}
\hline Vocábulo & Transcrição \\
\hline could & kUd (strong form) - kəd (weak form) \\
\hline cure & $\begin{array}{l}\text { kjur (AmE) - kjuər, kjo: } \\
(\mathrm{BrE})\end{array}$ \\
\hline cut & kıt \\
\hline dear & dir (AmE) - diə $\theta^{r}(B r E)$ \\
\hline Dutch & dıt \\
\hline early & $I_{3: r l I}$ (AmE) - I $3: r l I$ (BrE) \\
\hline eight & eit \\
\hline few & fju: \\
\hline first & f3:rst (AmE) - f3:st (BrE) \\
\hline five & farv \\
\hline flour & flaur (AmE) - flauər (BrE) \\
\hline foil & forl \\
\hline four & fo:r (AmE) - fo: $:^{r}(B r E)$ \\
\hline get & get \\
\hline
\end{tabular}

\begin{tabular}{|c|c|}
\hline Vocábulo & Transcrição \\
\hline new & nu: , nju: (AmE) - nju: (BrE) \\
\hline not & na:t (AmE) - not (BrE) \\
\hline of & $\begin{array}{l}\text { a:V (AmE) - DV (BrE) (strong forms) - əV (weak } \\
\text { form) }\end{array}$ \\
\hline oil & orl \\
\hline olive & 'a:IIV (AmE) - 'Dliv (BrE) \\
\hline or & O:r (AmE) - $\mathbf{O :}^{\mathrm{r}}$ (BrE) \\
\hline orange & 'O:rind3 (AmE) - 'Drind3 , 'o:rənd3 (BrE) \\
\hline paper & 'peipər (AmE) - 'peipər (BrE) \\
\hline pears & perz (AmE) - peər $(\mathrm{BrE})$ \\
\hline peppers & 'pepərz (AmE) - ' 'pepə'z (BrE) \\
\hline pickles & Iprklz \\
\hline plates & plerts \\
\hline please & pli:z \\
\hline pot & pa:t (AmE) - pDt (BrE) \\
\hline
\end{tabular}

\begin{tabular}{|c|c|}
\hline Vocábulo & Transcrição \\
\hline three & Ori: \\
\hline tins & $\operatorname{tInz}$ \\
\hline to & $\begin{array}{l}\text { tu: (strong form) } / / \text { tə , tə , tU (AmE) - tU , tə } \\
\text { (BrE) (weak forms) }\end{array}$ \\
\hline tomatoes & tə'mertouz (AmE) - tə'ma:təuz (BrE) \\
\hline tubes & $\begin{array}{l}\text { tu:bz, tju:bz (AmE) - tju:bz, t } \int u: b z \\
(B r E)\end{array}$ \\
\hline two & tu: \\
\hline useful & lju:sf'l, lju:sful \\
\hline very & 'verI \\
\hline white & wart \\
\hline whole & houl (AmE) - həul (BrE) \\
\hline wine & wain \\
\hline yellow & 'jelou (AmE) - ljeləu (BrE) \\
\hline you & ju: (strong form) - jU, jə (weak form) \\
\hline you're & 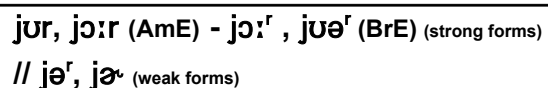 \\
\hline
\end{tabular}




\section{Anexo C - Tabela Com o Total dos Vocábulos do Texto}

Tabela com a Contagem TOTAL dos Vocábulos do Texto

\begin{tabular}{|c|c|c|}
\hline Vocábulos do Texto & $\begin{array}{c}\text { Vocábulos com Fonema } \\
\text { Consonantal Final }\end{array}$ & $\begin{array}{c}\text { Vocábulos com Fonema } \\
\text { Vocálico Final }\end{array}$ \\
\hline $\mathbf{9 8}$ & $\mathbf{7 7}$ & $\mathbf{2 1}$ \\
\hline
\end{tabular}




\section{Anexo D - Questionário}

\section{Questionário para Pesquisa Lingüística}

\section{Caros alunos,}

Primeiramente quero agradecer sua colaboração para nossa pesquisa.

E, também, instruí-los quanto à responsabilidade em responder sinceramente as questões.

O objetivo dessa pesquisa é observar a partir da fala gravada e transcrita dos falantes adultos do português, os aspectos que geraram dificuldades durante o processo de aquisição e aprendizagem fonológica da língua inglesa, no ensino superior.

Quanto à utilização da gravação da fala registrada em equipamentos eletrônicos para a referida pesquisa, bem como a sua reprodução para fins didáticos será garantido o sigilo e a privacidade dos dados coletados.

1) Você é natural do:
a) ( ) Brasil
b) ( ) outro país.
Qual?

2) Seu pai é natural do:
a) ( ) Brasil
b) ( ) outro país.
Qual?

3) Sua mãe é natural do:
a) ( ) Brasil
b) ( ) outro país.
Qual?

4) Você nasceu em:
a) ( ) São Paulo - capital
b) ( ) São Paulo - interior. Qual cidade?
c) ( ) outra cidade do Brasil. Qual?

5) Qual é sua idade?
a) ( ) 19 anos
h) ( ) 26 anos
b) ( ) 20 anos
i) ( ) 27 anos
c) ( ) 21 anos
j) ( ) 28 anos
d) ( ) 22 anos
k) ( ) 29 anos
e) ( ) 23 anos
l) ( ) 30 anos
f) ( ) 24 anos
m) ( ) Ou quantos anos?
g) ( ) 25 anos

6) Seu estado civil é:
a) ( ) solteiro(a)
c) ( ) viúvo(a)
b) ( ) casado(a)
d) ( ) outro. Qual?

7) Você tem filhos?
a) ( ) sim
b) ( ) não

8) Qual é o bairro que você reside (se você reside em São Paulo - capital)? 
9) Qual é sua atividade empregatícia?
a) ( ) possui empresa
b) ( ) vendedor
f) ( ) revisor de texto
c) ( ) bancário(a)
g) ( ) secretária
d) ( ) professor
h) ( ) jornalista
e) ( ) tradutor / intérprete
i) ( ) desempregado(a)
j) ( ) outra. Qual?

10) Qual é sua renda familiar (em salários mínimos)?
a) ( ) de 1 a 4
b) ( ) de 5 salários
c) ( ) de 6 salários
d) ( ) de 7 salários
e) ( ) de 8 salários
f) ( ) de 9 salários
g) ( ) de 10 salários
h) ( ) de 11 salários
i) ( ) de 12 salários
j) ( ) mais de 13 salários. Quantos?

11) Você fez o ensino médio:
a) ( ) todo na escola pública
b) ( ) todo na escola particular
c) ( ) parte na escola pública, parte na particular
d) ( ) no ensino supletivo

12) Em que ano você completou o ensino médio?
a) ( ) antes de 2000. Quando?
b) ( ) 2001
c) ( ) 2002

13) Com que idade?
a) ( ) 17 anos
d) ( ) 20 anos
b) ( ) 18 anos
e) ( ) mais de 20 anos. Quanto?
c) ( ) 19 anos

14) Você estudou sem interrupção?
a) ( ) $\operatorname{sim}$
b) ( ) não

15) Você possui outra graduação?
a) ( ) sim. Qual?
b) ( ) não

16) Você já freqüentou algum curso de inglês?
a) ( ) sim. Qual?
b) ( ) não

17) Você tem interesse em aprender outra língua estrangeira?
a) ( ) sim
b) ( ) não

18) Qual?
a) ( ) Espanhol
e) ( ) Japonês
b) ( ) Francês
f) ( ) Chinês
c) ( ) Italiano
d) ( ) Alemão

19) Você já sentiu necessidade em saber uma língua estrangeira em seu trabalho?
a) ( ) sim. Qual? 
b) ( ) não

20) O motivo pelo qual você optou por este curso foi:
a) ( ) porque era meu ideal
b) ( ) por motivos profissionais
c) ( ) porque quero ser professor de Inglês
d) ( ) porque quero ser professor de Português
e) ( ) porque quero ser professor de literatura
f) ( ) porque quero ser tradutor
g) ( ) porque quero ser intérprete
h) ( ) por falta de opção
i) ( ) por outro motivo. Qual?

21) Você pretende continuar seus estudos?
a) ( ) $\operatorname{sim}$
b) ( ) não

22) Qual é sua maior motivação para estudar língua inglesa?
a) ( ) por curiosidade
b) ( ) por motivo profissional
c) ( ) para conhecer melhor a cultura e os costumes do povo
d) ( ) para falar e entender melhor
e) ( ) para melhorar a habilidade de ler
f) ( ) para melhorar a habilidade de escrever
g) ( ) para melhorar a habilidade de ouvir
h) ( ) para melhorar a habilidade de falar
i) ( ) para melhorar a habilidade de traduzir
j) ( ) outra. Qual?

23) Durante o processo de aquisição de uma língua estrangeira, você considera mais fácil:
a) ( ) falar
b) ( ) ler
c) ( ) ouvir
e) ( ) Por que?
d) ( ) escrever

24) Durante o processo de aquisição de uma língua estrangeira, você considera mais difícil:
a) ( ) falar
c) ( ) ouvir
b) ( ) ler
d) ( ) escrever
e) ( ) Por que?

25) Até o momento, que nível estrutural da língua estrangeira tem sido de mais difícil aquisição e compreensão para você?
a) ( ) fonético-fonológico
b) ( ) morfossintático
c) ( ) lexical

26) Durante o processo de ensino-aprendizagem da língua inglesa, você considera o ensino da pronúncia:
a) ( ) supérfluo
c) ( ) outro. Qual?
b) ( ) importante

27) Você fala, lê ou escreve em outra língua, além do Português?
a) $(\quad) \operatorname{sim}$
b) ( ) não 
28) Qual?
a) ( ) Inglês
d) ( ) Italiano
b) ( ) Francês
e) ( ) Alemão
c) ( ) Espanhol
f) ( ) outra. Qual?

29) Desde quando você tem contato com essa língua?
a) ( ) de 6 meses a uma ano e meio
b) ( ) de 2 a 4 anos
c) ( ) de 4 anos e meio a 6 anos e meio
d) ( ) mais de 7 anos

30) Você aprendeu essa outra língua em uma escola especializada?
a) ( ) não
b) ( ) sim. Qual?

31) Durante quantos anos?
a) ( ) de um a 2 anos
d) ( ) de 3 a 4 anos
b) ( ) de 2 a 3 anos
e) ( ) de 4 a 5 anos
c) ( ) mais de 5 anos

32) Você sabe nessa língua estrangeira:

falar: ( ) bem

ler: ( ) bem

escrever: ( ) bem

ouvir: ( ) bem
( ) razoável

( ) razoável

( ) razoável
( ) sofrível

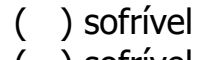

( ) sofrível

\section{Aluno cedente:}

Nome:

Dados Pessoais:

Telefone(s):

e-mail:

Dados Escolares:

Série: Turma: 


\section{Anexo E - Tabelas com a Articulação Inadequada dos Sujeitos}

\begin{tabular}{|c|c|c|c|c|}
\hline \multicolumn{5}{|c|}{ Sujeito $1-1^{a}$ coleta } \\
\hline $\begin{array}{c}\text { Fonemas } \\
\text { observados }\end{array}$ & $\begin{array}{c}\text { Vocábulos } \\
\text { escritos }\end{array}$ & $\begin{array}{c}\text { Fonemas } \\
\text { pronunciados } \\
\text { com "erro" }\end{array}$ & Transcrição fonológica correta & $\begin{array}{c}\text { Transcrição fonológica } \\
\text { com "erro" }\end{array}$ \\
\hline k & book & kI & /buk/ & /bu'kI/ \\
\hline $\mathrm{g}$ & bag & gI & /bæg/ & /'bægi/ \\
\hline $\mathrm{v}$ & of & $f$ & /a:v/ (AmE) - /pv/ (BrE) (strong forms) - /əv/ (weak form) & $/ \mathrm{dof} /$ \\
\hline Z & kilos & - & /'ki:louz/ (AmE) - /'ki:ləuz/ (BrE) & /'ki:lou_l \\
\hline \multirow{5}{*}{ I } & useful & w & /'ju:sfəl/, /lju:sful/ & l'ju:sfuw/ \\
\hline & sole & - & /soul/ (AmE) - /səul/ (BrE) & /sou/ \\
\hline & whole & II & /houl/ (AmE) - /həul/ (BrE) & /'Wolis/ \\
\hline & oil & $U$ & /วIl/ & /OIU/ \\
\hline & foil & $U$ & /forl/ & /foiv/ \\
\hline \multirow[t]{2}{*}{$\mathrm{m}$} & some & $\mathrm{mI}$ & /s^m/ (strong form) - /səm/ (weak form) & /salms/ \\
\hline & ham & - & /hæm/ & /raN/ \\
\hline $\mathrm{n}$ & wine & $\mathrm{nI}$ & /wain/ & /'naini/ \\
\hline
\end{tabular}

\begin{tabular}{|c|c|c|c|c|}
\hline \multicolumn{5}{|c|}{ Sujeito $1-2^{a}$ coleta } \\
\hline $\begin{array}{l}\text { Fonemas } \\
\text { observados }\end{array}$ & $\begin{array}{l}\text { Vocábulos } \\
\text { escritos }\end{array}$ & $\begin{array}{c}\text { Fonemas } \\
\text { pronunciados } \\
\text { com "erro" }\end{array}$ & Transcrição fonológica correta & $\begin{array}{c}\text { Transcrição fonológica } \\
\text { com "erro" }\end{array}$ \\
\hline $\mathrm{k}$ & book & $\mathrm{kI}$ & /buk/ & /bu'kI/ \\
\hline \multirow[t]{2}{*}{ v } & of & $\mathrm{f}$ & /a:v/ (AmE) - /Dv/ (BrE) (strong forms) - /əv/ (weak form) & $/ \mathrm{Df} /$ \\
\hline & olive & VI & /'a:IIv/ (AmE) - /'oliv/ (BrE) & /'olivi/ \\
\hline I & useful & w & /'ju:sfəl/, /ju:sful/ & lju:sfow/ \\
\hline $\mathrm{m}$ & ham & - & /hæm/ & /raN/ \\
\hline \multirow[t]{2}{*}{$\mathrm{n}$} & wine & nI & /wain/ & /'naini/ \\
\hline & thin & $\mathrm{t}$ & /Oin/ & $/ \theta \mathrm{iN} /$ \\
\hline
\end{tabular}




\begin{tabular}{|c|c|c|c|c|}
\hline \multicolumn{5}{|c|}{ Sujeito $2-1^{a}$ coleta } \\
\hline $\begin{array}{c}\text { Fonemas } \\
\text { observados }\end{array}$ & $\begin{array}{l}\text { Vocábulos } \\
\text { escritos }\end{array}$ & $\begin{array}{l}\text { Fonemas } \\
\text { pronunciados } \\
\text { com "erro" }\end{array}$ & Transcrição fonológica correta & $\begin{array}{c}\text { Transcrição fonológica } \\
\text { com "erro" }\end{array}$ \\
\hline V & of & $f$ & $\begin{array}{c}\text { /a:v/ (AmE) - /Dv/ (BrE) (strong forms) } \\
/ \text { /əv/ (weak form) }\end{array}$ & /pf/ \\
\hline \multirow{3}{*}{ I } & useful & $w$ & /'ju:sfəl/, /'ju:sful/ & /lju:sfow/ \\
\hline & oil & $U$ & /วIl/ & /OIU/ \\
\hline & foil & $U$ & /forl/ & /forU/ \\
\hline
\end{tabular}

\begin{tabular}{|c|c|c|c|c|}
\hline \multicolumn{5}{|c|}{ Sujeito $2-2^{a}$ coleta } \\
\hline $\begin{array}{c}\text { Fonemas } \\
\text { observados }\end{array}$ & $\begin{array}{l}\text { Vocábulos } \\
\text { escritos }\end{array}$ & $\begin{array}{l}\text { Fonemas } \\
\text { pronunciados } \\
\text { com "erro" }\end{array}$ & Transcrição fonológica correta & $\begin{array}{c}\text { Transcrição fonológica } \\
\text { com "erro" } \\
\end{array}$ \\
\hline $\mathbf{v}$ & of & $f$ & $\begin{array}{c}\text { /a:v/ (AmE) - /Dv/ (BrE) (strong forms) } \\
\text { /əv/ (weak form) }\end{array}$ & /of/ \\
\hline $\mathrm{I}$ & useful & w & /'ju:sfəl/, /lju:sful/ & /lju:sfuw/ \\
\hline
\end{tabular}




\begin{tabular}{|c|c|c|c|c|}
\hline \multicolumn{5}{|c|}{ Sujeito $3-1^{a}$ coleta } \\
\hline $\begin{array}{c}\text { Fonemas } \\
\text { observados }\end{array}$ & $\begin{array}{l}\text { Vocábulos } \\
\text { escritos }\end{array}$ & $\begin{array}{c}\text { Fonemas } \\
\text { pronunciados } \\
\text { com "erro" }\end{array}$ & Transcrição fonológica correta & $\begin{array}{l}\text { Transcrição } \\
\text { Fonológica } \\
\text { com "erro" }\end{array}$ \\
\hline $\mathrm{f}$ & of & $\mathrm{f}$ & $\begin{array}{c}\text { /a:v/ (AmE) - / } \mathrm{pv} / \text { (BrE) (strong forms) } \\
/ \text { /əv/ (weak form) }\end{array}$ & /pf/ \\
\hline \multirow{5}{*}{ I } & useful & w & /l'ju:sfəl/, /'ju:sful/ & /ju:sfuw/ \\
\hline & whole & II & /houl/ (AmE) - /həul// (BrE) & /'woulI/ \\
\hline & sole & _- & /soul/ (AmE) - /səul/ (BrE) & /soul \\
\hline & oil & $u$ & /oil/ & /oIU/ \\
\hline & foil & U & /fэil/ & /foIU/ \\
\hline
\end{tabular}

\begin{tabular}{|c|c|c|c|c|}
\hline \multicolumn{5}{|c|}{ Sujeito $3-2^{a}$ coleta } \\
\hline $\begin{array}{l}\text { Fonemas } \\
\text { observados }\end{array}$ & $\begin{array}{c}\begin{array}{l}\text { Vocábulos } \\
\text { escritos }\end{array} \\
\end{array}$ & $\begin{array}{l}\text { Fonemas } \\
\text { pronunciados } \\
\text { com "erro" }\end{array}$ & Transcrição fonológica correta & $\begin{array}{c}\text { Transcrição fonológica } \\
\text { com "erro" }\end{array}$ \\
\hline$f$ & of & $f$ & $\begin{array}{c}\text { /a:v/ (AmE) - /pv/ (BrE) (strong forms) } \\
/ \text { /əv/ (weak form) }\end{array}$ & /pf/ \\
\hline \multirow[t]{2}{*}{1} & apples & ou & I'æplzl & /'epouz/ \\
\hline & useful & w & /'ju:sfəl/, /'ju:sful/ & /'ju:sfuw/ \\
\hline
\end{tabular}




\begin{tabular}{|c|c|c|c|c|}
\hline \multicolumn{5}{|c|}{ Sujeito $4-1^{a}$ coleta } \\
\hline $\begin{array}{c}\text { Fonemas } \\
\text { observados }\end{array}$ & $\begin{array}{l}\text { Vocábulos } \\
\text { escritos }\end{array}$ & $\begin{array}{c}\text { Fonemas } \\
\text { pronunciados } \\
\text { com "erro" }\end{array}$ & Transcrição fonológica correta & $\begin{array}{c}\text { Transcrição fonológica } \\
\text { com "erro" }\end{array}$ \\
\hline \multirow[t]{2}{*}{$\mathrm{t}$} & light & $\mathrm{tI}$ & /lart/ & /'larti/ \\
\hline & white & tI & /wart/ & /'warti/ \\
\hline \multirow{4}{*}{ I } & whole & $\mathrm{w}$ & /houl/ (AmE) - /həul/ (BrE) & $/ \mathrm{hou}^{\mathrm{w}} /$ \\
\hline & sole & - & /soul/ (AmE) - /səul/ (BrE) & /sou/ \\
\hline & oil & U & /oil/ & /OIU/ \\
\hline & foil & $U$ & $/$ forl/ & /forv/ \\
\hline
\end{tabular}

\begin{tabular}{|c|c|c|c|c|}
\hline \multicolumn{2}{|c|}{ Sujeito 4-2 $\mathbf{2}^{\text {a }}$ coleta } \\
\hline $\begin{array}{c}\text { Fonemas } \\
\text { observados }\end{array}$ & $\begin{array}{c}\text { Vocábulos } \\
\text { escritos }\end{array}$ & $\begin{array}{c}\text { Fonemas } \\
\text { pronunciados } \\
\text { com "erro" }\end{array}$ & Transcrição fonológica correta & $\begin{array}{c}\text { Transcrição fonológica } \\
\text { com "erro" }\end{array}$ \\
\hline & & & & \\
\hline
\end{tabular}




\begin{tabular}{|c|c|c|c|c|}
\hline \multicolumn{5}{|c|}{ Sujeito $5-1^{a}$ coleta } \\
\hline \begin{tabular}{|l} 
Fonemas \\
observados
\end{tabular} & $\begin{array}{l}\text { Vocábulos } \\
\text { escritos }\end{array}$ & $\begin{array}{c}\text { Fonemas } \\
\text { pronunciados } \\
\text { com "erro" }\end{array}$ & Transcrição fonológica correta & $\begin{array}{c}\text { Transcrição fonológica } \\
\text { com "erro" }\end{array}$ \\
\hline $\mathrm{v}$ & of & $f$ & $\begin{array}{c}\text { /a:v/ (AmE) - /DV/ (BrE) (strong forms) } \\
\text { /əv/ (weak form) }\end{array}$ & /Df/ \\
\hline \multirow{5}{*}{ I } & useful & $w$ & /'ju:sfal/, /'ju:sful/ & /ju:sfuw/ \\
\hline & whole & $\mathrm{II}_{\mathrm{I}}$ & /houl/ (AmE) - /həul/ (BrE) & /'woulI/ \\
\hline & sole & - & /soul/ (AmE) - /səul/ (BrE) & /sou/ \\
\hline & oil & $U$ & /oil/ & /วIU/ \\
\hline & foil & $U$ & /foil/ & /foru/ \\
\hline $\mathrm{n}$ & wine & $\overline{\mathrm{nI}}$ & /wain/ & /'waini/ \\
\hline
\end{tabular}

\begin{tabular}{|c|c|c|c|c|}
\hline $\begin{array}{c}\text { Fonemas } \\
\text { observados }\end{array}$ & $\begin{array}{c}\text { Vocábulos } \\
\text { escritos }\end{array}$ & $\begin{array}{c}\text { Fonemas } \\
\text { pronunciados } \\
\text { com "erro" }\end{array}$ & Transcrição fonológica correta & $\begin{array}{c}\text { Transcrição fonológica } \\
\text { com "erro" }\end{array}$ \\
\hline $\mathrm{I}$ & useful & $\mathrm{w}$ & /'ju:sfal//,/ju:sful/ & /'ju:sfu'/ \\
\hline $\mathrm{n}$ & wine & $\mathrm{nI}$ & /waIn/ & /'waInI/ \\
\hline
\end{tabular}




\begin{tabular}{|c|c|c|c|c|}
\hline \multicolumn{5}{|c|}{ Sujeito $6-1^{a}$ coleta } \\
\hline $\begin{array}{c}\text { Fonemas } \\
\text { observados }\end{array}$ & $\begin{array}{l}\text { Vocábulos } \\
\text { escritos }\end{array}$ & $\begin{array}{c}\text { Fonemas } \\
\text { pronunciados } \\
\text { com "erro" }\end{array}$ & Transcrição fonológica correta & $\begin{array}{c}\text { Transcrição fonológica } \\
\text { com "erro" }\end{array}$ \\
\hline $\mathbf{v}$ & of & $f$ & $\begin{array}{c}\text { /a:v/ (AmE) - /ov/ (BrE) (strong forms) } \\
/ \text { /əv/ (weak form) }\end{array}$ & /pf/ \\
\hline \multirow{5}{*}{ I } & useful & w & /lju:sfəl/, /lju:sful/ & lju:sfuw/ \\
\hline & sole & II & /soul/ (AmE) - /səul/ (BrE) & /'souli/ \\
\hline & whole & II & /houl/ (AmE) - /həul/ (BrE) & /'wolı/ \\
\hline & oil & $\bar{U}$ & /วIl/ & /כıU/ \\
\hline & foil & $U$ & /forl/ & /forU/ \\
\hline $\mathrm{m}$ & ham & - & /hæm/ & /riN/ \\
\hline $\mathrm{n}$ & wine & $\mathrm{nI}$ & /wain/ & /'waini/ \\
\hline
\end{tabular}

\begin{tabular}{|c|c|c|c|c|}
\hline \multicolumn{5}{|c|}{ Sujeito $6-2^{a}$ coleta } \\
\hline $\begin{array}{c}\text { Fonemas } \\
\text { observados }\end{array}$ & $\begin{array}{c}\text { Vocábulos } \\
\text { escritos }\end{array}$ & $\begin{array}{c}\text { Fonemas } \\
\text { pronunciados } \\
\text { com "erro" }\end{array}$ & Transcrição fonológica correta & $\begin{array}{c}\text { Transcrição fonológica } \\
\text { com "erro" }\end{array}$ \\
\hline$v$ & of & $f$ & $\begin{array}{c}\text { /a:v/ (AmE) - /Dv/ (BrE) (strong forms) } \\
\text { /əv/ (weak form) }\end{array}$ & /pf/ \\
\hline \multirow[t]{2}{*}{ I } & whole & II & /houl/ (AmE) - /həul/ (BrE) & /'WoulI/ \\
\hline & useful & w & /lju:sfəl/, /lju:sful/ & /ju:sfuw/ \\
\hline $\mathrm{n}$ & wine & $\mathrm{nI}$ & /wain/ & /'wainI/ \\
\hline
\end{tabular}




\begin{tabular}{|c|c|c|c|c|}
\hline \multicolumn{5}{|c|}{ Sujeito $7-1^{a}$ coleta } \\
\hline $\begin{array}{c}\text { Fonemas } \\
\text { observados }\end{array}$ & $\begin{array}{l}\text { Vocábulos } \\
\text { escritos }\end{array}$ & $\begin{array}{c}\text { Fonemas } \\
\text { pronunciados } \\
\text { com "erro" }\end{array}$ & Transcrição fonológica correta & $\begin{array}{l}\text { Transcrição } \\
\text { fonológica } \\
\text { com "erro" }\end{array}$ \\
\hline $\mathrm{t}$ & hot & $\mathrm{tI}$ & /ha:t/ (AmE) - /hpt/ (BrE) & /'rotI/ \\
\hline $\mathrm{k}$ & book & kI & /buk/ & /bu'kI/ \\
\hline$g$ & bag & gI & /bæg/ & /'begI/ \\
\hline v & of & $f$ & $\begin{array}{c}\text { /a:v/ (AmE) - /pv/ (BrE) (strong forms) } \\
\text { /əv/ (weak form) }\end{array}$ & /pf/ \\
\hline \multirow{5}{*}{ I } & useful & w & /lju:sfəl/, /lju:sful/ & /ju:sfuw/ \\
\hline & sole & - & /soul/ (AmE) - /səul/ (BrE) & /sou/ \\
\hline & whole & II & /houl/ (AmE) - /həul/ (BrE) & /'rouli/ \\
\hline & oil & $U$ & /วIl/ & /วเU/ \\
\hline & foil & $U$ & /fכrl/ & /forU/ \\
\hline $\mathrm{m}$ & ham & - & /hæm/ & /raN/ \\
\hline $\mathrm{n}$ & thin & - & /OIn/ & /siN/ \\
\hline
\end{tabular}

\begin{tabular}{|c|c|c|c|c|}
\hline \multicolumn{5}{|c|}{ Sujeito $7-2^{a}$ coleta } \\
\hline $\begin{array}{l}\text { Fonemas } \\
\text { observados }\end{array}$ & $\begin{array}{l}\text { Vocábulos } \\
\text { escritos }\end{array}$ & $\begin{array}{l}\text { Fonemas } \\
\text { pronunciados } \\
\text { com "erro" }\end{array}$ & Transcrição fonológica correta & $\begin{array}{l}\text { Transcrição } \\
\text { fonológica } \\
\text { com "erro" }\end{array}$ \\
\hline $\mathrm{k}$ & book & $\mathrm{kI}$ & /buk/ & /bu'kI/ \\
\hline g & bag & gI & /bæg/ & /'begi/ \\
\hline \multirow[b]{2}{*}{ I } & useful & w & /lju:sfəl/, /ju:sful/ & /ju:sfow/ \\
\hline & whole & II & /houl/ (AmE) - /həul/ (BrE) & /'roulı/ \\
\hline
\end{tabular}




\begin{tabular}{|c|c|c|c|c|}
\hline \multicolumn{5}{|c|}{ Sujeito $8-1^{a}$ coleta } \\
\hline $\begin{array}{l}\text { Fonemas } \\
\text { observados }\end{array}$ & $\begin{array}{l}\text { Vocábulos } \\
\text { escritos }\end{array}$ & $\begin{array}{l}\text { Fonemas } \\
\text { pronunciados } \\
\text { com "erro" }\end{array}$ & Transcrição fonológica correta & $\begin{array}{c}\text { Transcrição fonológica } \\
\text { com "erro" }\end{array}$ \\
\hline $\mathrm{t}$ & hot & tI & /ha:t/ (AmE) - /hot/ (BrE) & /'roti/ \\
\hline V & of & $f$ & $\begin{array}{c}\text { /a:v/ (AmE) - /ov/ (BrE) (strong forms) } \\
/ \text { /əv/ (weak form) }\end{array}$ & /pf/ \\
\hline \multirow{4}{*}{ I } & sole & II & /soul/ (AmE) - /səul/ (BrE) & /'souli/ \\
\hline & whole & II & /houl/ (AmE) - /həul/ (BrE) & /'houlı/ \\
\hline & oil & U & /วIl/ & /วıU/ \\
\hline & foil & U & /fərl/ & /forv/ \\
\hline $\mathrm{m}$ & ham & - & /hæm/ & /raN/ \\
\hline \multirow{3}{*}{$\mathrm{n}$} & ten & - & /ten/ & /teiN/ \\
\hline & wine & $\mathrm{nI}$ & /wain/ & /'wainı/ \\
\hline & thin & - & /Oin/ & $/ \mathrm{fiN} /$ \\
\hline
\end{tabular}

\begin{tabular}{|c|c|c|c|c|}
\hline \multicolumn{5}{|c|}{ Sujeito $8-2^{a}$ coleta } \\
\hline $\begin{array}{c}\text { Fonemas } \\
\text { observados }\end{array}$ & $\begin{array}{c}\text { Vocábulos } \\
\text { escritos }\end{array}$ & $\begin{array}{l}\text { Fonemas } \\
\text { pronunciados } \\
\text { com "erro" }\end{array}$ & Transcrição fonológica correta & $\begin{array}{c}\text { Transcrição fonológica } \\
\text { com "erro" }\end{array}$ \\
\hline $\mathrm{t}$ & hot & tI & /ha:t/ (AmE) - /hot/ (BrE) & /'roti/ \\
\hline \multirow{3}{*}{ I } & whole & II & /houl/ (AmE) - /həul/ (BrE) & /'houlI/ \\
\hline & oil & $U$ & /OIl/ & /OIU/ \\
\hline & foil & $U$ & /fərl/ & /forU/ \\
\hline $\mathrm{m}$ & ham & - & /hæm/ & /haN/ \\
\hline $\mathrm{n}$ & ten & - & /ten/ & /teiN/ \\
\hline
\end{tabular}




\begin{tabular}{|c|c|c|c|c|}
\hline \multicolumn{5}{|c|}{ Sujeito $9-1^{a}$ coleta } \\
\hline $\begin{array}{l}\text { Fonemas } \\
\text { observados }\end{array}$ & $\begin{array}{l}\text { Vocábulos } \\
\text { escritos }\end{array}$ & $\begin{array}{c}\text { Fonemas } \\
\text { pronunciados } \\
\text { com "erro" } \\
\end{array}$ & Transcrição fonológica correta & $\begin{array}{l}\text { Transcrição } \\
\text { fonológica } \\
\text { com "erro" }\end{array}$ \\
\hline $\mathrm{t}$ & hot & tI & /ha:t/ (AmE) - /hot/ (BrE) & /'roti/ \\
\hline $\mathrm{k}$ & book & $\mathrm{kI}$ & /buk/ & /bu'ks/ \\
\hline $\mathrm{v}$ & of & $f$ & $\begin{array}{c}\text { /a:v/ (AmE) - /ov/ (BrE) (strong forms) } \\
\text { /əv/ (weak form) }\end{array}$ & /of/ \\
\hline \multirow{5}{*}{ I } & useful & $\mathrm{w}$ & /'ju:sfəl/, /'ju:sful/ & /ju:sfow/ \\
\hline & sole & II & /soul/ (AmE) - /səul/ (BrE) & /'soulI/ \\
\hline & whole & II & /houl/ (AmE) - /həul/ (BrE) & /'houlı/ \\
\hline & oil & $U$ & /OII/ & /OIU/ \\
\hline & foil & U & /fうil/ & /forU/ \\
\hline \multirow[t]{2}{*}{$\mathrm{m}$} & some & $\mathrm{mI}$ & /s^m/ (strong form) - /səm/ (weak form) & /səlmI/ \\
\hline & ham & - & /hæm/ & /haN/ \\
\hline $\mathrm{n}$ & wine & $\mathrm{nI}$ & /wain/ & /'waini/ \\
\hline
\end{tabular}

\begin{tabular}{|c|c|c|c|c|}
\hline \multicolumn{5}{|c|}{ Sujeito $9-2^{a}$ coleta } \\
\hline $\begin{array}{l}\text { Fonemas } \\
\text { observados }\end{array}$ & $\begin{array}{l}\text { Vocábulos } \\
\text { escritos }\end{array}$ & \begin{tabular}{|c|} 
Fonemas \\
pronunciados \\
com "erro"
\end{tabular} & Transcrição fonológica correta & $\begin{array}{l}\text { Transcrição } \\
\text { fonológica } \\
\text { com "erro" }\end{array}$ \\
\hline \multirow[t]{2}{*}{$\mathrm{I}$} & whole & II & /houl/ (AmE) - /həul/ (BrE) & /'houlı/ \\
\hline & useful & w & /lju:sfəl/, /lju:sful/ & /ju:sfow/ \\
\hline
\end{tabular}




\begin{tabular}{|c|c|c|c|c|}
\hline \multicolumn{5}{|c|}{ Sujeito $10-1^{a}$ coleta } \\
\hline $\begin{array}{c}\text { Fonemas } \\
\text { observados }\end{array}$ & $\begin{array}{l}\text { Vocábulos } \\
\text { escritos }\end{array}$ & $\begin{array}{c}\text { Fonemas } \\
\text { pronunciados } \\
\text { com "erro" } \\
\end{array}$ & Transcrição fonológica correta & $\begin{array}{c}\text { Transcrição fonológica } \\
\text { com "erro" }\end{array}$ \\
\hline$t$ & hot & $\mathrm{tI}$ & /ha:t/ (AmE) - /hpt/ (BrE) & /'hotI/ \\
\hline $\mathrm{d}$ & red & $\mathrm{dI}$ & /red/ & /'redi/ \\
\hline v & of & $f$ & $\begin{array}{c}\text { /a:v/ (AmE) - /ov/ (BrE) (strong forms) } \\
/ \text { /əv/ (weak form) }\end{array}$ & $/ \mathrm{pf} /$ \\
\hline z & kilos & s & /'kilouz/ (AmE) - /'kiləuz/ (BrE) & /'kalous/ \\
\hline \multirow{5}{*}{ I } & useful & $\mathrm{w}$ & /lju:sfəl/, /'ju:sful/ & /ju:sfow/ \\
\hline & sole & II & /soul/ (AmE) - /səul/ (BrE) & /Solis/ \\
\hline & whole & II & /houl/ (AmE) - /həul/ (BrE) & /ro'lis/ \\
\hline & oil & $U$ & /OIl/ & /วIU/ \\
\hline & foil & $U$ & /forl/ & /foiv/ \\
\hline $\mathrm{m}$ & ham & - & /hæm/ & /haN/ \\
\hline
\end{tabular}

\begin{tabular}{|c|c|c|c|c|}
\hline \multicolumn{5}{|c|}{ Sujeito $10-2^{a}$ coleta } \\
\hline $\begin{array}{l}\text { Fonemas } \\
\text { observados }\end{array}$ & $\begin{array}{c}\text { Vocábulos } \\
\text { escritos }\end{array}$ & $\begin{array}{c}\text { Fonemas } \\
\text { pronunciados } \\
\text { com "erro" }\end{array}$ & Transcrição fonológica correta & $\begin{array}{c}\text { Transcrição fonológica } \\
\text { com "erro" }\end{array}$ \\
\hline $\mathrm{t}$ & hot & $\mathrm{tI}$ & /ha:t/ (AmE) - /hot/ (BrE) & /'hotI/ \\
\hline \multirow[t]{2}{*}{ I } & useful & w & /lju:sfəl/, /lju:sful/ & /ju:sfuw/ \\
\hline & foil & $U$ & /forl/ & /foiv/ \\
\hline $\mathrm{m}$ & ham & - & /hæm/ & /haN/ \\
\hline
\end{tabular}




\begin{tabular}{|c|c|c|c|c|}
\hline \multicolumn{5}{|c|}{ Sujeito $11-1^{a}$ coleta } \\
\hline $\begin{array}{c}\text { Fonemas } \\
\text { observados }\end{array}$ & $\begin{array}{c}\text { Vocábulos } \\
\text { escritos }\end{array}$ & $\begin{array}{l}\text { Fonemas } \\
\text { pronunciados } \\
\text { com "erro" }\end{array}$ & Transcrição fonológica correta & $\begin{array}{l}\text { Transcrição } \\
\text { fonológica } \\
\text { com "erro" }\end{array}$ \\
\hline $\mathrm{k}$ & book & kI & /buk/ & /bu'kI/ \\
\hline v & of & $f$ & $\begin{array}{c}\text { /a:v/ (AmE) - /ov/ (BrE) (strong forms) } \\
/ \text { /əv/ (weak form) }\end{array}$ & /of/ \\
\hline \multirow{3}{*}{ I } & useful & w & /lju:sfəl/, /lju:sful/ & /ju:sfuw/ \\
\hline & oil & $U$ & /OIl/ & /OIU/ \\
\hline & foil & $U$ & /forl/ & /forU/ \\
\hline \multirow[t]{2}{*}{$\mathrm{m}$} & some & $\mathrm{mI}$ & /s^m/ (strong form) - /səm/ (weak form) & /sə'mI/ \\
\hline & ham & - & /hæm/ & /haN/ \\
\hline$n$ & thin & - & /Oin/ & $/ \mathrm{tiN} /$ \\
\hline
\end{tabular}

\begin{tabular}{|c|c|c|c|c|}
\hline \multicolumn{5}{|c|}{ Sujeito $11-2^{a}$ coleta } \\
\hline $\begin{array}{l}\text { Fonemas } \\
\text { observados }\end{array}$ & $\begin{array}{c}\text { Vocábulos } \\
\text { escritos }\end{array}$ & $\begin{array}{c}\text { Fonemas } \\
\text { pronunciados } \\
\text { com "erro" }\end{array}$ & Transcrição fonológica correta & $\begin{array}{l}\text { Transcrição } \\
\text { fonológica } \\
\text { com "erro" }\end{array}$ \\
\hline $\mathrm{I}$ & useful & $w$ & /'ju:sfəl/, /'ju:sful/ & /'ju:sfuw/ \\
\hline \multirow[t]{2}{*}{$\mathrm{m}$} & some & $\mathrm{mI}$ & /s^m/ (strong form) - /səm/ (weak form) & /sə'mI/ \\
\hline & ham & - & /hæm/ & /haN/ \\
\hline
\end{tabular}




\begin{tabular}{|c|c|c|c|c|}
\hline \multicolumn{5}{|c|}{ Sujeito $12-1^{a}$ coleta } \\
\hline $\begin{array}{c}\text { Fonemas } \\
\text { observados }\end{array}$ & $\begin{array}{l}\text { Vocábulos } \\
\text { escritos }\end{array}$ & $\begin{array}{c}\text { Fonemas } \\
\text { pronunciados } \\
\text { com "erro" } \\
\end{array}$ & Transcrição fonológica correta & $\begin{array}{l}\text { Transcrição } \\
\text { fonológica } \\
\text { com "erro" }\end{array}$ \\
\hline v & of & $f$ & $\begin{array}{c}\text { /a:v/ (AmE) - /pv/ (BrE) (strong forms) } \\
/ \partial v / \text { (weak form) }\end{array}$ & /pf/ \\
\hline \multirow{5}{*}{ I } & useful & $\mathrm{w}$ & /lju:sfəl/, /lju:sful/ & /ju:sfuw/ \\
\hline & whole & $\mathrm{w}$ & /houl/ (AmE) - /həul/ (BrE) & /'wolI/ \\
\hline & sole & - & /soul/ (AmE) - /səul/ (BrE) & /sou/ \\
\hline & oil & U & /วIl/ & /OIU/ \\
\hline & foil & U & /fうil/ & /forU/ \\
\hline $\mathrm{m}$ & ham & - & /hæm/ & /haN/ \\
\hline $\mathrm{n}$ & wine & $\mathrm{nI}$ & /wain/ & /wai'nI/ \\
\hline
\end{tabular}

\begin{tabular}{|c|c|c|c|c|}
\hline \multicolumn{5}{|c|}{ Sujeito $12-2^{a}$ coleta } \\
\hline $\begin{array}{c}\text { Fonemas } \\
\text { observados }\end{array}$ & $\begin{array}{l}\text { Vocábulos } \\
\text { escritos }\end{array}$ & $\begin{array}{c}\text { Fonemas } \\
\text { pronunciados } \\
\text { com "erro" }\end{array}$ & Transcrição fonológica correta & $\begin{array}{l}\text { Transcrição } \\
\text { fonológica } \\
\text { com "erro" }\end{array}$ \\
\hline \multirow[t]{2}{*}{$\mathrm{I}$} & useful & $\mathrm{w}$ & /'ju:sfəl/, /lju:sful/ & l'ju:sfow/ \\
\hline & whole & w & /houl/ (AmE) - /həul/ (BrE) & /'wolı/ \\
\hline$m$ & ham & - & /hæm/ & /haN/ \\
\hline
\end{tabular}




\begin{tabular}{|c|c|c|c|c|}
\hline \multicolumn{5}{|c|}{ Sujeito $13-1^{a}$ coleta } \\
\hline $\begin{array}{l}\text { Fonemas } \\
\text { observados }\end{array}$ & $\begin{array}{l}\text { Vocábulos } \\
\text { escritos }\end{array}$ & $\begin{array}{l}\text { Fonemas } \\
\text { pronunciados } \\
\text { com "erro" }\end{array}$ & Transcrição fonológica correta & $\begin{array}{l}\text { Transcrição } \\
\text { fonológica } \\
\text { com "erro" }\end{array}$ \\
\hline \multirow[t]{2}{*}{$\mathrm{I}$} & useful & w & /ju:sfəl/, /ju:sful/ & /lju:sfuw/ \\
\hline & whole & w & /houl/ (AmE) - /həul/ (BrE) & /'roulI/ \\
\hline $\mathrm{m}$ & ham & - & /hæm/ & /haN/ \\
\hline \multicolumn{5}{|c|}{ Sujeito $13-2^{a}$ coleta } \\
\hline $\begin{array}{l}\text { Fonemas } \\
\text { observados }\end{array}$ & $\begin{array}{l}\text { Vocábulos } \\
\text { escritos }\end{array}$ & \begin{tabular}{|c|} 
Fonemas \\
pronunciados \\
com "erro"
\end{tabular} & Transcrição fonológica correta & $\begin{array}{l}\text { Transcrição } \\
\text { fonológica } \\
\text { com "erro" }\end{array}$ \\
\hline I & useful & w & /ju:sfəl/, /ju:sful/ & /ju:sfuw/ \\
\hline $\mathrm{m}$ & ham & | & /hæm/ & /haN/ \\
\hline
\end{tabular}




\begin{tabular}{|c|c|c|c|c|}
\hline \multicolumn{5}{|c|}{ Sujeito $14-1^{a}$ coleta } \\
\hline $\begin{array}{c}\text { Fonemas } \\
\text { observados }\end{array}$ & $\begin{array}{l}\text { Vocábulos } \\
\text { escritos }\end{array}$ & $\begin{array}{c}\text { Fonemas } \\
\text { pronunciados } \\
\text { com "erro" }\end{array}$ & Transcrição fonológica correta & $\begin{array}{l}\text { Transcrição } \\
\text { fonológica } \\
\text { com "erro" }\end{array}$ \\
\hline \multirow[t]{2}{*}{$\mathrm{t}$} & eight & $\mathrm{tI}$ & /eit/ & /'erti/ \\
\hline & white & tI & /wait/ & /wiN'ti/ \\
\hline $\mathrm{k}$ & book & $\mathrm{kI}$ & /buk/ & /bu'ks/ \\
\hline g & bag & gI & /bæg/ & /'bægI/ \\
\hline $\mathrm{v}$ & of & $f$ & /a:v/ (AmE) - /ov/ (BrE) (strong forms) - /əv/ (weak form) & $/ \mathrm{pf} /$ \\
\hline $\mathrm{t} \int$ & Dutch & ks & $/ \mathrm{d} \wedge \mathrm{t} \int /$ & /duks/ \\
\hline$r$ & sure & rI & 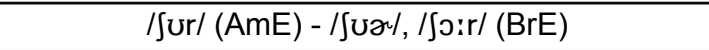 & / $\mathrm{SaNrI} /$ \\
\hline \multirow{5}{*}{ I } & useful & w & /'ju:sfəl/, /lju:sful/ & /'ju:sfuw/ \\
\hline & whole & le & /houl/ (AmE) - /həul/ (BrE) & /ru'le/ \\
\hline & sole & le & /soul/ (AmE) - /səul/ (BrE) & /solle/ \\
\hline & oil & U & /oil/ & loiv/ \\
\hline & foil & $U$ & /forl/ & /foiv/ \\
\hline $\mathrm{m}$ & ham & - & /hæm/ & /raN/ \\
\hline
\end{tabular}

\begin{tabular}{|c|c|c|c|c|}
\hline \multicolumn{5}{|c|}{ Sujeito $14-2^{a}$ coleta } \\
\hline $\begin{array}{c}\text { Fonemas } \\
\text { observados }\end{array}$ & $\begin{array}{l}\text { Vocábulos } \\
\text { escritos }\end{array}$ & \begin{tabular}{|c|} 
Fonemas \\
pronunciados \\
com "erro"
\end{tabular} & Transcrição fonológica correta & $\begin{array}{l}\text { Transcrição } \\
\text { fonológica } \\
\text { com "erro" }\end{array}$ \\
\hline $\mathrm{t}$ & eight & $\mathrm{tI}$ & leit/ & /'erti/ \\
\hline $\mathrm{v}$ & of & f & /a:v/ (AmE) - /Dv/ (BrE) (strong forms) - /əv/ (weak form) & $/ \mathrm{pf} /$ \\
\hline$t \int$ & Dutch & st & $/ \mathrm{d} \wedge \mathrm{t} \int /$ & /dzuks/ \\
\hline \multirow{5}{*}{ I } & useful & w & /'ju:sfal/, /'ju:sful/ & /ju:sfow/ \\
\hline & whole & le & /houl/ (AmE) - /həul/ (BrE) & /roulle/ \\
\hline & sole & le & /soul/ (AmE) - /səul/ (BrE) & /soule/ \\
\hline & oil & $U$ & /OIl/ & loiv/ \\
\hline & foil & U & /forl/ & /foiv/ \\
\hline $\mathrm{m}$ & ham & - & /hæm/ & /raN/ \\
\hline
\end{tabular}




\begin{tabular}{|c|c|c|c|c|}
\hline \multicolumn{5}{|c|}{ Sujeito $15-1^{a}$ coleta } \\
\hline $\begin{array}{c}\text { Fonemas } \\
\text { observados }\end{array}$ & $\begin{array}{l}\text { Vocábulos } \\
\text { escritos }\end{array}$ & $\begin{array}{l}\text { Fonemas } \\
\text { pronunciados } \\
\text { com "erro" }\end{array}$ & Transcrição fonológica correta & $\begin{array}{l}\text { Transcrição } \\
\text { fonológica } \\
\text { com "erro" }\end{array}$ \\
\hline \multirow{4}{*}{$\mathrm{t}$} & hot & tI & /ha:t/ (AmE) - /hnt/ (BrE) & /'hoti/ \\
\hline & eight & tI & /ert/ & /'eiti/ \\
\hline & light & tI & /lart/ & /lai'til/ \\
\hline & white & tI & /wart/ & /waI'ti/ \\
\hline $\mathrm{k}$ & book & $\mathrm{kI}$ & /buk/ & /'bu:ki/ \\
\hline v & of & $f$ & $\begin{array}{c}\text { /a:v/ (AmE) - /pv/ (BrE) (strong forms) } \\
\text { /əv/ (weak form) }\end{array}$ & /Df/ \\
\hline \multirow{5}{*}{1} & useful & $\mathrm{w}$ & /'ju:sfəl/, /lju:sful/ & /ju:sfuw/ \\
\hline & whole & - & /houl/ (AmE) - /həul/ (BrE) & /hou/ \\
\hline & sole & - & /soul/ (AmE) - /səul/ (BrE) & /sou/ \\
\hline & oil & $U$ & /OIl/ & /OIU/ \\
\hline & foil & 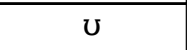 & /forl/ & /foru/ \\
\hline $\mathrm{m}$ & ham & - & /hæm/ & /haN/ \\
\hline \multirow[t]{2}{*}{$\mathrm{n}$} & wine & $\mathrm{nI}$ & /waIn/ & /waI'nI/ \\
\hline & thin & - & $/ \theta \mathrm{in} /$ & $/ \mathrm{fiN} /$ \\
\hline
\end{tabular}

\begin{tabular}{|c|c|c|c|c|}
\hline \multicolumn{5}{|c|}{ Sujeito $15-2^{a}$ coleta } \\
\hline $\begin{array}{c}\text { Fonemas } \\
\text { observados }\end{array}$ & $\begin{array}{l}\text { Vocábulos } \\
\text { escritos }\end{array}$ & $\begin{array}{c}\text { Fonemas } \\
\text { pronunciados } \\
\text { com "erro" }\end{array}$ & Transcrição fonológica correta & $\begin{array}{l}\text { Transcriçãa } \\
\text { fonológica } \\
\text { com "erro" }\end{array}$ \\
\hline \multirow[t]{2}{*}{$\mathrm{t}$} & light & $\mathrm{tI}$ & /lait/ & /lai'tr/ \\
\hline & white & $\mathrm{tI}$ & /waIt/ & /waI'ts/ \\
\hline \multirow[t]{2}{*}{1} & whole & II & /houl/ (AmE) - /həul/ (BrE) & /'rouli/ \\
\hline & useful & w & /lju:sfəl/, /lju:sful/ & /ju:sfuw/ \\
\hline $\mathrm{m}$ & ham & - & /hæm/ & /haN/ \\
\hline \multirow[t]{2}{*}{$\mathrm{n}$} & wine & $\mathrm{nI}$ & /wain/ & /WaI'nI/ \\
\hline & thin & - & /Oin/ & $/ \theta \mathrm{iN} /$ \\
\hline
\end{tabular}




\begin{tabular}{|c|c|c|c|c|}
\hline \multicolumn{5}{|c|}{ Sujeito $16-1^{a}$ coleta } \\
\hline $\begin{array}{c}\text { Fonemas } \\
\text { observados }\end{array}$ & $\begin{array}{l}\text { Vocábulos } \\
\text { escritos }\end{array}$ & $\begin{array}{l}\text { Fonemas } \\
\text { pronunciados } \\
\text { com "erro" }\end{array}$ & Transcrição fonológica correta & $\begin{array}{l}\text { Transcrição } \\
\text { fonológica } \\
\text { com "erro" }\end{array}$ \\
\hline v & of & $f$ & $\begin{array}{c}\text { /a:v/ (AmE) - /ov/ (BrE) (strong forms) } \\
/ \text { /əv/ (weak form) }\end{array}$ & /of/ \\
\hline$r$ & cure & rI & /kjur/ (AmE) - /kjuəl, /kjo:r/ (BrE) & /'kãNrı/ \\
\hline \multirow{5}{*}{ I } & useful & w & /lju:sfəl/, /lju:sful/ & /ju:sfow/ \\
\hline & whole & II & /houl/ (AmE) - /həul/ (BrE) & I'roulı/ \\
\hline & sole & - & /soul/ (AmE) - /səul/ (BrE) & /sou/ \\
\hline & oil & $U$ & /วIl/ & /כIU/ \\
\hline & foil & $U$ & /forl/ & /faiu/ \\
\hline
\end{tabular}

\begin{tabular}{|c|c|c|c|c|}
\hline \multicolumn{5}{|c|}{ Sujeito $16-2^{a}$ coleta } \\
\hline $\begin{array}{l}\text { Fonemas } \\
\text { observados }\end{array}$ & $\begin{array}{l}\text { Vocábulos } \\
\text { escritos }\end{array}$ & $\begin{array}{l}\text { Fonemas } \\
\text { pronunciados } \\
\text { com "erro" } \\
\end{array}$ & Transcrição fonológica correta & $\begin{array}{l}\text { Transcrição } \\
\text { fonológica } \\
\text { com "erro" }\end{array}$ \\
\hline v & of & $f$ & $\begin{array}{c}\text { /a:v/ (AmE) - /Dv/ (BrE) (strong forms) } \\
/ \partial v / \text { (weak form) }\end{array}$ & /of/ \\
\hline \multirow{3}{*}{1} & useful & $\mathrm{w}$ & /lju:sfəl/, /lju:sful/ & /ju:sfuw/ \\
\hline & oil & $U$ & /OIl/ & /OIU/ \\
\hline & foil & $U$ & /fうil/ & /faru/ \\
\hline
\end{tabular}




\begin{tabular}{|c|c|c|c|c|}
\hline \multicolumn{5}{|c|}{ Sujeito $17-1^{a}$ coleta } \\
\hline $\begin{array}{c}\text { Fonemas } \\
\text { observados }\end{array}$ & $\begin{array}{l}\text { Vocábulos } \\
\text { escritos }\end{array}$ & $\begin{array}{c}\text { Fonemas } \\
\text { pronunciados } \\
\text { com "erro" } \\
\end{array}$ & Transcrição fonológica correta & $\begin{array}{l}\text { Transcrição } \\
\text { fonológica } \\
\text { com "erro" }\end{array}$ \\
\hline $\mathrm{t}$ & hot & tI & /ha:t/ (AmE) - /hbt/ (BrE) & /hotı/ \\
\hline v & of & $f$ & $\begin{array}{c}\text { /a:v/ (AmE) - /ov/ (BrE) (strong forms) } \\
\text { /əv/ (weak form) }\end{array}$ & /Df/ \\
\hline \multirow[t]{2}{*}{ I } & oil & $\bar{U}$ & /วтl/ & /כIU/ \\
\hline & foil & U & /forl/ & /forU/ \\
\hline $\mathrm{m}$ & ham & - & /hæm/ & /raN/ \\
\hline
\end{tabular}

\begin{tabular}{|c|c|c|c|c|}
\hline \multicolumn{2}{|c|}{ Sujeito 17 - 2a coleta } \\
\hline $\begin{array}{c}\text { Fonemas } \\
\text { observados }\end{array}$ & $\begin{array}{c}\text { Vocábulos } \\
\text { escritos }\end{array}$ & $\begin{array}{c}\text { Fonemas } \\
\text { pronunciados } \\
\text { com "erro" }\end{array}$ & Transcrição fonológica correta & $\begin{array}{c}\text { Transcrição } \\
\text { fonológica } \\
\text { com "erro" }\end{array}$ \\
\hline $\mathrm{m}$ & ham & - & $/ \mathrm{hæm} /$ & $/ \mathrm{raN} /$ \\
\hline
\end{tabular}




\begin{tabular}{|c|c|c|c|c|}
\hline \multicolumn{5}{|c|}{ Sujeito $18-1^{a}$ coleta } \\
\hline $\begin{array}{c}\text { Fonemas } \\
\text { observados }\end{array}$ & $\begin{array}{l}\text { Vocábulos } \\
\text { escritos }\end{array}$ & $\begin{array}{c}\text { Fonemas } \\
\text { pronunciados } \\
\text { com "erro" }\end{array}$ & Transcrição fonológica correta & $\begin{array}{l}\text { Transcrição } \\
\text { fonológica } \\
\text { com "erro" }\end{array}$ \\
\hline \multirow{3}{*}{$\mathrm{t}$} & hot & $\mathrm{tI}$ & /ha:t/ (AmE) - /hpt/ (BrE) & /'hotI/ \\
\hline & light & tI & /lait/ & /lai'tI/ \\
\hline & white & $\mathrm{tI}$ & /wart/ & /WaI'tr/ \\
\hline v & of & $f$ & $\begin{array}{c}\text { /a:v/ (AmE) - /pv/ (BrE) (strong forms) } \\
\text { /əv/ (weak form) }\end{array}$ & /pf/ \\
\hline \multirow{3}{*}{ I } & useful & w & /lju:sfəl/, /'ju:sful/ & /ju:sfuw/ \\
\hline & whole & le & /houl/ (AmE) - /həul/ (BrE) & /'houle/ \\
\hline & sole & II & /soul/ (AmE) - /səul/ (BrE) & /sou'lI/ \\
\hline
\end{tabular}

\begin{tabular}{|c|c|c|c|c|}
\hline \multicolumn{5}{|c|}{ Sujeito $18-2^{a}$ coleta } \\
\hline $\begin{array}{c}\text { Fonemas } \\
\text { observados }\end{array}$ & $\begin{array}{l}\text { Vocábulos } \\
\text { escritos }\end{array}$ & $\begin{array}{c}\text { Fonemas } \\
\text { pronunciados } \\
\text { com "erro" }\end{array}$ & Transcrição fonológica correta & $\begin{array}{l}\text { Transcrição } \\
\text { fonológica } \\
\text { com "erro" }\end{array}$ \\
\hline $\mathrm{t}$ & hot & tI & /ha:t/ (AmE) - /hpt/ (BrE) & /'hoti/ \\
\hline \multirow{3}{*}{1} & useful & $\mathrm{w}$ & /'ju:sfəl/, /'ju:sful/ & /'ju:sfow/ \\
\hline & whole & le & /houl/ (AmE) - /həul/ (BrE) & /houle/ \\
\hline & sole & II & /soul/ (AmE) - /səul/ (BrE) & /sou'l|I/ \\
\hline
\end{tabular}




\begin{tabular}{|c|c|c|c|c|}
\hline \multicolumn{5}{|c|}{ Sujeito $19-1^{a}$ coleta } \\
\hline $\begin{array}{c}\text { Fonemas } \\
\text { observados }\end{array}$ & $\begin{array}{l}\text { Vocábulos } \\
\text { escritos }\end{array}$ & $\begin{array}{l}\text { Fonemas } \\
\text { pronunciados } \\
\text { com "erro" }\end{array}$ & Transcrição fonológica correta & $\begin{array}{l}\text { Transcrição } \\
\text { fonológica } \\
\text { com "erro" }\end{array}$ \\
\hline $\mathrm{t}$ & hot & $\mathrm{tI}$ & /ha:t/ (AmE) - /hot/ (BrE) & /hoti/ \\
\hline $\mathrm{v}$ & of & $f$ & $\begin{array}{c}\text { /a:v/ (AmE) - /pv/ (BrE) (strong forms) } \\
\text { /əv/ (weak form) }\end{array}$ & /pf/ \\
\hline \multirow{5}{*}{ I } & useful & w & /'ju:sfal/, /lju:sful/ & /ju:sfow/ \\
\hline & whole & II & /houl/ (AmE) - /həul/ (BrE) & /'woulI/ \\
\hline & sole & - & /soul/ (AmE) - /səul/ (BrE) & /sou/ \\
\hline & oil & U & /OIl/ & /OIU/ \\
\hline & foil & U & /forl/ & /fכIU/ \\
\hline \multirow[t]{2}{*}{$\mathrm{m}$} & some & $\mathrm{mI}$ & /s^m/ (strong form) - /səm/ (weak form) & /sə'mI/ \\
\hline & ham & - & /hæm/ & /raN/ \\
\hline
\end{tabular}

\begin{tabular}{|c|c|c|c|c|}
\hline \multicolumn{5}{|c|}{ Sujeito $19-2^{a}$ coleta } \\
\hline $\begin{array}{c}\text { Fonemas } \\
\text { observados }\end{array}$ & $\begin{array}{c}\text { Vocábulos } \\
\text { escritos }\end{array}$ & $\begin{array}{c}\text { Fonemas } \\
\text { pronunciados } \\
\text { com "erro" }\end{array}$ & Transcrição fonológica correta & $\begin{array}{l}\text { Transcrição } \\
\text { fonológica } \\
\text { com "erro" }\end{array}$ \\
\hline$z$ & these & ZI & /ði:z/ & /'di:zI/ \\
\hline \multirow[t]{4}{*}{ I } & useful & w & /'ju:sfəl/, /'ju:sful/ & /ju:sfow/ \\
\hline & whole & II & /houl/ (AmE) - /həul/ (BrE) & /'WoulI/ \\
\hline & oil & U & /OIl/ & /วгU/ \\
\hline & foil & $U$ & /fכil/ & /foIU/ \\
\hline $\mathrm{m}$ & ham & - & /hæm/ & /raN/ \\
\hline $\mathrm{n}$ & wine & $\mathrm{nI}$ & /wain/ & /waI'nI/ \\
\hline
\end{tabular}




\begin{tabular}{|c|c|c|c|c|}
\hline \multicolumn{5}{|c|}{ Sujeito $20-1^{a}$ coleta } \\
\hline Fonemas observados & Vocábulos escritos & $\begin{array}{c}\text { Fonemas pronunciados } \\
\text { com "erro" }\end{array}$ & Transcrição fonológica correta & $\begin{array}{c}\text { Transcrição fonológica } \\
\text { com "erro" }\end{array}$ \\
\hline \multirow[t]{2}{*}{$\mathrm{v}$} & of & $f$ & $\begin{array}{c}/ \mathrm{a}: \mathrm{v} /(\mathrm{AmE})-/ \mathrm{Dv} / \text { (BrE) (strong forms) } \\
/ \text { /əv/ (weak form) }\end{array}$ & $/ \mathrm{pf} /$ \\
\hline & olive & - & /'a:liv/ (AmE) - /'oliv/ (BrE) & /'Dlivi/ \\
\hline $\mathrm{t} \int$ & Dutch & st & $/ \mathrm{d} \wedge \mathrm{t} \int /$ & /dzəst/ \\
\hline \multirow{5}{*}{1} & useful & w & /'ju:sfəl/, /lju:sful/ & /lju:sfuw/ \\
\hline & whole & II & /houl/ (AmE) - /həul/ (BrE) & /houli/ \\
\hline & sole & II & /soul/ (AmE) - /səul/ (BrE) & /'soulI/ \\
\hline & oil & u & /oIl/ & loul \\
\hline & foil & u: & /forl// & /fu:/ \\
\hline $\mathrm{m}$ & ham & - & /hæm/ & $/ \mathrm{raN} /$ \\
\hline $\mathrm{n}$ & thin & - & /Oin/ & $/ \mathrm{siN} /$ \\
\hline
\end{tabular}

\begin{tabular}{|c|c|c|c|c|}
\hline \multicolumn{5}{|c|}{ Sujeito $20-2^{a}$ coleta } \\
\hline $\begin{array}{c}\text { Fonemas } \\
\text { observados }\end{array}$ & $\begin{array}{c}\text { Vocábulos } \\
\text { escritos }\end{array}$ & $\begin{array}{c}\text { Fonemas } \\
\text { pronunciados } \\
\text { com "erro" }\end{array}$ & Transcrição fonológica correta & $\begin{array}{l}\text { Transcrição } \\
\text { fonológica } \\
\text { com "erro" }\end{array}$ \\
\hline $\mathrm{t} \int$ & Dutch & st & $/ \mathrm{d} \wedge \mathrm{t} \int /$ & /dzost/ \\
\hline \multirow{4}{*}{ I } & whole & II & /houl/ (AmE) - /həul/ (BrE) & /houli/ \\
\hline & sole & II & /soul/ (AmE) - /səul/ (BrE) & /'soulI/ \\
\hline & oil & U & /OIl/ & /ov/ \\
\hline & foil & כU & /fวil/ & /fつU/ \\
\hline$m$ & ham & - & /hæm/ & /raN/ \\
\hline
\end{tabular}




\begin{tabular}{|c|c|c|c|c|}
\hline \multicolumn{5}{|c|}{ Sujeito $21-1^{a}$ coleta } \\
\hline $\begin{array}{l}\text { Fonemas } \\
\text { observados }\end{array}$ & $\begin{array}{l}\text { Vocábulos } \\
\text { escritos }\end{array}$ & $\begin{array}{l}\text { Fonemas } \\
\text { pronunciados } \\
\text { com "erro" }\end{array}$ & Transcrição fonológica correta & $\begin{array}{l}\text { Transcrição } \\
\text { fonológica } \\
\text { com "erro" }\end{array}$ \\
\hline $\mathrm{t}$ & hot & $\mathrm{tI}$ & /ha:t/ (AmE) - /hot/ (BrE) & /'hoti/ \\
\hline$d$ & red & dI & /red/ & /'redi/ \\
\hline $\mathrm{v}$ & of & $f$ & $\begin{array}{c}\text { /a:v/ (AmE) - /pv/ (BrE) (strong forms) } \\
\text { /əv/ (weak form) }\end{array}$ & /Df/ \\
\hline $\mathrm{t} \int$ & Dutch & st & $/ \mathrm{d} \wedge \mathrm{t} \int /$ & /dzust/ \\
\hline \multirow{5}{*}{ I } & useful & w & /lju:sfəl/, /ju:sful/ & /ju:sfuw/ \\
\hline & whole & II & /houl/ (AmE) - /həul/ (BrE) & /'rouli/ \\
\hline & sole & - & /soul/ (AmE) - /səul/ (BrE) & /sou/ \\
\hline & oil & $U$ & /orl/ & /oul \\
\hline & foil & $U$ & /fכil/ & /fual \\
\hline $\mathrm{m}$ & ham & - & /hæm/ & /raN/ \\
\hline $\mathrm{n}$ & wine & $\mathrm{nI}$ & /wain/ & /wai'nI/ \\
\hline
\end{tabular}

\begin{tabular}{|c|c|c|c|c|}
\hline \multicolumn{5}{|c|}{ Sujeito $21-2^{a}$ coleta } \\
\hline $\begin{array}{l}\text { Fonemas } \\
\text { observados }\end{array}$ & $\begin{array}{c}\text { Vocábulos } \\
\text { escritos }\end{array}$ & $\begin{array}{c}\text { Fonemas } \\
\text { pronunciados } \\
\text { com "erro" }\end{array}$ & Transcrição fonológica correta & $\begin{array}{l}\text { Transcrição } \\
\text { fonológica } \\
\text { com "erro" }\end{array}$ \\
\hline $\mathrm{t} \int$ & Dutch & st & $/ \mathrm{d} \wedge \mathrm{t} \int /$ & /dzust/ \\
\hline $\mathrm{m}$ & ham & - & /hæm/ & /raN/ \\
\hline $\mathrm{n}$ & wine & $\mathrm{nI}$ & /wain/ & /wai'ni/ \\
\hline
\end{tabular}




\begin{tabular}{|c|c|c|c|c|}
\hline \multicolumn{5}{|c|}{ Sujeito $22-1^{a}$ coleta } \\
\hline $\begin{array}{c}\text { Fonemas } \\
\text { observados }\end{array}$ & $\begin{array}{l}\text { Vocábulos } \\
\text { escritos }\end{array}$ & $\begin{array}{c}\text { Fonemas } \\
\text { pronunciados } \\
\text { com "erro" } \\
\end{array}$ & Transcrição fonológica correta & $\begin{array}{l}\text { Transcrição } \\
\text { fonológica } \\
\text { com "erro" }\end{array}$ \\
\hline $\mathrm{t}$ & hot & $\mathrm{tI}$ & /ha:t/ (AmE) - /hot/ (BrE) & /hotI/ \\
\hline v & of & $f$ & $\begin{array}{c}\text { /a:v/ (AmE) - /ov/ (BrE) (strong forms) } \\
/ \text { /əv/ (weak form) }\end{array}$ & /pf/ \\
\hline \multirow[t]{3}{*}{ I } & useful & $\mathrm{w}$ & /lju:sfəl/, /ju:sful/ & lju:zfow/ \\
\hline & oil & $\bar{U}$ & /วil/ & /OIU/ \\
\hline & foil & $U$ & /forl/ & /foIU/ \\
\hline
\end{tabular}

\begin{tabular}{|c|c|c|c|c|}
\hline \multicolumn{5}{|c|}{ Sujeito $22-2^{a}$ coleta } \\
\hline $\begin{array}{l}\text { Fonemas } \\
\text { observados }\end{array}$ & $\begin{array}{l}\text { Vocábulos } \\
\text { escritos }\end{array}$ & $\begin{array}{l}\text { Fonemas } \\
\text { pronunciados } \\
\text { com "erro" }\end{array}$ & Transcrição fonológica correta & $\begin{array}{l}\text { Transcrição } \\
\text { fonológica } \\
\text { com "erro" }\end{array}$ \\
\hline $\mathrm{t}$ & hot & tI & /ha:t/ (AmE) - /hpt/ (BrE) & /'hoti/ \\
\hline v & of & $f$ & $\begin{array}{c}\text { /a:v/ (AmE) - /ov/ (BrE) (strong forms) } \\
/ \text { /əv/ (weak form) }\end{array}$ & /of/ \\
\hline \multirow{3}{*}{ I } & useful & w & /ju:sfəl/, /ju:sful/ & /ju:zfuw/ \\
\hline & oil & $U$ & /OIl/ & loiv/ \\
\hline & foil & $U$ & /forl/ & /forv/ \\
\hline
\end{tabular}




\begin{tabular}{|c|c|c|c|c|}
\hline \multicolumn{5}{|c|}{ Sujeito $23-1^{a}$ coleta } \\
\hline $\begin{array}{l}\text { Fonemas } \\
\text { observados }\end{array}$ & $\begin{array}{l}\text { Vocábulos } \\
\text { escritos }\end{array}$ & $\begin{array}{l}\text { Fonemas } \\
\text { pronunciados } \\
\text { com "erro" }\end{array}$ & Transcrição fonológica correta & $\begin{array}{l}\text { Transcrição } \\
\text { fonológica } \\
\text { com "erro" }\end{array}$ \\
\hline$d$ & red & dI & /red/ & /'redi/ \\
\hline v & of & $f$ & $\begin{array}{c}\text { /a:v/ (AmE) - /ov/ (BrE) (strong forms) } \\
\text { /əv/ (weak form) }\end{array}$ & /Df/ \\
\hline \multirow{5}{*}{ I } & useful & w & /ju:sfəl/, /lju:sful/ & /ju:zfuw/ \\
\hline & whole & II & /houl/ (AmE) - /həul/ (BrE) & /'rouli/ \\
\hline & sole & - & /soul/ (AmE) - /səul/ (BrE) & /sou/ \\
\hline & oil & $U$ & /orl/ & /OIU/ \\
\hline & foil & $\bar{U}$ & /fכil/ & /forU/ \\
\hline $\mathrm{m}$ & ham & - & /hæm/ & $/ \mathrm{raN} /$ \\
\hline
\end{tabular}

\begin{tabular}{|c|c|c|c|c|}
\hline \multicolumn{5}{|c|}{ Sujeito $23-2^{a}$ coleta } \\
\hline $\begin{array}{l}\text { Fonemas } \\
\text { observados }\end{array}$ & $\begin{array}{l}\text { Vocábulos } \\
\text { escritos }\end{array}$ & $\begin{array}{c}\text { Fonemas } \\
\text { pronunciados } \\
\text { com "erro" }\end{array}$ & Transcrição fonológica correta & $\begin{array}{l}\text { Transcrição } \\
\text { fonológica } \\
\text { com "erro" }\end{array}$ \\
\hline d & red & dI & /red/ & /'redI/ \\
\hline 1 & whole & II & /houl/ (AmE) - /həul/ (BrE) & /rou/ \\
\hline $\mathrm{m}$ & ham & - & /hæm/ & /raN/ \\
\hline
\end{tabular}




\begin{tabular}{|c|c|c|c|c|}
\hline \multicolumn{5}{|c|}{ Sujeito $24-1^{a}$ coleta } \\
\hline $\begin{array}{c}\text { Fonemas } \\
\text { observados }\end{array}$ & $\begin{array}{l}\text { Vocábulos } \\
\text { escritos }\end{array}$ & $\begin{array}{l}\text { Fonemas } \\
\text { pronunciados } \\
\text { com "erro" }\end{array}$ & Transcrição fonológica correta & $\begin{array}{l}\text { Transcrição } \\
\text { fonológica } \\
\text { com "erro" }\end{array}$ \\
\hline v & of & $f$ & $\begin{array}{c}\text { /a:v/ (AmE) - /Dv/ (BrE) (strong forms) } \\
\text { /əv/ (weak form) }\end{array}$ & /pf/ \\
\hline $\mathrm{z}$ & cheese & SI & $/ \mathrm{t} \int \mathrm{i} i z /$ & /ltei:si/ \\
\hline \multirow[t]{3}{*}{$\mathrm{I}$} & whole & lə & /houl/ (AmE) - /həul/ (BrE) & /'woule/ \\
\hline & oil & $U$ & /OIl/ & /วIU/ \\
\hline & foil & 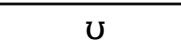 & /forl/ & /fכIU/ \\
\hline \multirow[t]{2}{*}{$\mathrm{m}$} & some & $\mathrm{mI}$ & /s^m/ (strong form) - /səm/ (weak form) & /salmI/ \\
\hline & ham & - & /hæm/ & /reiN/ \\
\hline
\end{tabular}

\begin{tabular}{|c|c|c|c|c|}
\hline \multicolumn{5}{|c|}{ Sujeito $24-2^{a}$ coleta } \\
\hline $\begin{array}{l}\text { Fonemas } \\
\text { observados }\end{array}$ & $\begin{array}{l}\text { Vocábulos } \\
\text { escritos }\end{array}$ & $\begin{array}{l}\text { Fonemas } \\
\text { pronunciados } \\
\text { com "erro" }\end{array}$ & Transcrição fonológica correta & $\begin{array}{l}\text { Transcrição } \\
\text { fonológica } \\
\text { com "erro" }\end{array}$ \\
\hline v & of & $f$ & $\begin{array}{c}\text { /a:v/ (AmE) - /Dv/ (BrE) (strong forms) } \\
\text { /əv/ (weak form) }\end{array}$ & /pf/ \\
\hline \multirow{3}{*}{ I } & whole & II & /houl/ (AmE) - /həul/ (BrE) & /'houlI/ \\
\hline & oil & $U$ & /OIl/ & /כIU/ \\
\hline & foil & $\bar{U}$ & /fวIl/ & /forU/ \\
\hline $\mathrm{m}$ & ham & & /hæm/ & /reiN/ \\
\hline
\end{tabular}




\begin{tabular}{|c|c|c|c|c|}
\hline \multicolumn{5}{|c|}{ Sujeito $25-1^{a}$ coleta } \\
\hline $\begin{array}{l}\text { Fonemas } \\
\text { observados }\end{array}$ & $\begin{array}{l}\text { Vocábulos } \\
\text { escritos }\end{array}$ & \begin{tabular}{|c} 
Fonemas \\
pronunciados \\
com "erro"
\end{tabular} & Transcrição fonológica correta & $\begin{array}{c}\text { Transcrição fonológica } \\
\text { com "erro" }\end{array}$ \\
\hline $\mathrm{v}$ & of & $f$ & $\begin{array}{c}\text { /a:v/ (AmE) - /Dv/ (BrE) (strong forms) } \\
\text { /əv/ (weak form) }\end{array}$ & /of/ \\
\hline $\mathrm{m}$ & ham & - & /hæm/ & /haN/ \\
\hline
\end{tabular}

\begin{tabular}{|c|c|c|c|c|}
\hline \multicolumn{5}{|c|}{ Sujeito $25-2^{a}$ coleta } \\
\hline $\begin{array}{l}\text { Fonemas } \\
\text { observados }\end{array}$ & $\begin{array}{l}\text { Vocábulos } \\
\text { escritos }\end{array}$ & \begin{tabular}{|c} 
Fonemas \\
pronunciados \\
com "erro"
\end{tabular} & Transcrição fonológica correta & $\begin{array}{c}\text { Transcrição fonológica } \\
\text { com "erro" }\end{array}$ \\
\hline v & of & $f$ & $\begin{array}{c}\text { /a:v/ (AmE) - /Dv/ (BrE) (strong forms) } \\
\text { /əv/ (weak form) }\end{array}$ & /of/ \\
\hline
\end{tabular}




\begin{tabular}{|c|c|c|c|c|}
\hline \multicolumn{5}{|c|}{ Sujeito $26-1^{a}$ coleta } \\
\hline \begin{tabular}{c|} 
Fonemas \\
observados
\end{tabular} & $\begin{array}{l}\text { Vocábulos } \\
\text { escritos }\end{array}$ & \begin{tabular}{|c} 
Fonemas \\
pronunciados \\
com "erro"
\end{tabular} & Transcrição fonológica correta & $\begin{array}{l}\text { Transcrição } \\
\text { fonológica } \\
\text { com "erro" }\end{array}$ \\
\hline d & red & dI & /red/ & /'redi/ \\
\hline $\mathrm{k}$ & book & kI & /buk/ & /'buki/ \\
\hline g & bag & gI & /bæg/ & /'bægI/ \\
\hline $\mathrm{v}$ & of & $f$ & $\begin{array}{c}\text { /a:v/ (AmE) - /Dv/ (BrE) (strong forms) } \\
/ \text { /əv/ (weak form) }\end{array}$ & $/ \mathrm{dof} /$ \\
\hline \multirow{5}{*}{ I } & useful & $\mathrm{w}$ & /lju:sfəl/, /ju:sful/ & /ju:sfuw/ \\
\hline & whole & II & /houl/ (AmE) - /həul/ (BrE) & /'waiu/ \\
\hline & sole & w & /soul/ (AmE) - /səul/ (BrE) & /souw/ \\
\hline & oil & U & /OIl/ & /כIU/ \\
\hline & foil & $U$ & /forl/ & /forU/ \\
\hline \multirow[t]{2}{*}{$\mathrm{m}$} & some & $\mathrm{mI}$ & /s^m/ (strong form) - /səm/ (weak form) & /sə'mI/ \\
\hline & ham & - & /hæm/ & /raN/ \\
\hline
\end{tabular}

\begin{tabular}{|c|c|c|c|c|}
\hline \multicolumn{5}{|c|}{ Suieito $26-2^{a}$ coleta } \\
\hline $\begin{array}{c}\text { Fonemas } \\
\text { observados }\end{array}$ & $\begin{array}{c}\text { Vocábulos } \\
\text { escritos }\end{array}$ & \begin{tabular}{|c} 
Fonemas \\
pronunciados \\
com "erro"
\end{tabular} & Transcrição fonológica correta & $\begin{array}{l}\text { Transcrição } \\
\text { fonológica } \\
\text { com "erro" }\end{array}$ \\
\hline $\mathrm{k}$ & book & $\mathrm{kI}$ & /buk/ & /'buki/ \\
\hline $\mathrm{g}$ & bag & gI & /bæg/ & /'bægi/ \\
\hline $\mathrm{v}$ & of & $f$ & $\begin{array}{c}\text { /a:v/ (AmE) - /Dv/ (BrE) (strong forms) } \\
/ \partial v / \text { (weak form) }\end{array}$ & $/ \mathrm{dof} /$ \\
\hline
\end{tabular}




\begin{tabular}{|c|c|c|c|c|}
\hline \multicolumn{5}{|c|}{ Sujeito $27-1^{a}$ coleta } \\
\hline $\begin{array}{l}\text { Fonemas } \\
\text { observados }\end{array}$ & $\begin{array}{l}\text { Vocábulos } \\
\text { escritos }\end{array}$ & \begin{tabular}{|c|} 
Fonemas \\
pronunciados \\
com "erro"
\end{tabular} & Transcrição fonológica correta & $\begin{array}{l}\text { Transcrição } \\
\text { fonológica } \\
\text { com "erro" }\end{array}$ \\
\hline \multirow[t]{2}{*}{$\mathrm{t}$} & pot & tI & /pa:t/ (AmE) - /ppt/ (BrE) & /'ppti/ \\
\hline & hot & tI & /ha:t/ (AmE) - /hpt/ (BrE) & /'hoti/ \\
\hline k & book & kI & /buk/ & /'buki/ \\
\hline $\mathbf{v}$ & of & $f$ & $\begin{array}{c}\text { /a:v/ (AmE) - /ov/ (BrE) (strong forms) } \\
/ \partial v /(\text { weak form) }\end{array}$ & $/ \mathrm{Df} /$ \\
\hline t5 & Dutch & $\mathrm{k}$ & $/ \mathrm{d} \wedge \mathrm{t} \int /$ & $/ \mathrm{d} \wedge \mathrm{k} /$ \\
\hline \multirow[t]{2}{*}{ I } & oil & $U$ & /OIl/ & /OIU/ \\
\hline & foil & $U$ & /forl/ & /foru/ \\
\hline $\mathrm{m}$ & ham & - & /hæm/ & /haN/ \\
\hline $\mathrm{n}$ & wine & $\mathrm{nI}$ & /wain/ & /'waini/ \\
\hline
\end{tabular}

\begin{tabular}{|c|c|c|c|c|}
\hline \multicolumn{7}{|c|}{$\begin{array}{c}\text { Sujeito 27 - 2a coleta } \\
\text { Fonemas } \\
\text { observados }\end{array}$} & $\begin{array}{c}\text { Vocábulos } \\
\text { escritos }\end{array}$ & $\begin{array}{c}\text { Fonemas } \\
\text { pronunciados } \\
\text { com “erro" }\end{array}$ & Transcrição fonológica correta & $\begin{array}{c}\text { Transcrição } \\
\text { fonológica } \\
\text { com "erro" }\end{array}$ \\
\hline $\mathrm{I}$ & oil & $\mathrm{U}$ & /oIl/ & /OIU/ \\
\cline { 2 - 6 } & foil & $\mathrm{U}$ & /forl/ & /foru/ \\
\hline $\mathrm{n}$ & wine & $\mathrm{nI}$ & /waIn/ & /WaInI/ \\
\hline
\end{tabular}




\begin{tabular}{|c|c|c|c|c|}
\hline \multicolumn{5}{|c|}{ Sujeito $28-1^{a}$ coleta } \\
\hline $\begin{array}{l}\text { Fonemas } \\
\text { observados }\end{array}$ & $\begin{array}{l}\text { Vocábulos } \\
\text { escritos }\end{array}$ & \begin{tabular}{|c|} 
Fonemas \\
pronunciados \\
com "erro"
\end{tabular} & Transcrição fonológica correta & $\begin{array}{l}\text { Transcrição } \\
\text { fonológica } \\
\text { com "erro" }\end{array}$ \\
\hline $\mathrm{v}$ & of & $f$ & $\begin{array}{c}\text { /a:v/ (AmE) - /pv/ (BrE) (strong forms) } \\
/ \text { /əv/ (weak form) }\end{array}$ & $/ \mathrm{pf} /$ \\
\hline $\mathrm{s}$ & potatoes & $s$ & /pə'tertouz/ (AmE) - /pə'tertəuz/ (BrE) & /to'meitou_/ \\
\hline \multirow{4}{*}{ I } & useful & $\mathrm{w}$ & /lju:sfəl/, /lju:sful/ & /ju:sfuw/ \\
\hline & whole & II & /houl/ (AmE) - /həul/ (BrE) & /houlı/ \\
\hline & oil & $\bar{U}$ & /วIl/ & /OIU/ \\
\hline & foil & $U$ & /forl/ & /forU/ \\
\hline $\mathrm{m}$ & ham & - & /hæm/ & /haN/ \\
\hline
\end{tabular}

\begin{tabular}{|c|c|c|c|c|}
\hline \multicolumn{2}{|c|}{ Sujeito 28 - 2 $\mathbf{2}^{\mathbf{a}}$ coleta } \\
$\begin{array}{c}\text { Fonemas } \\
\text { observados }\end{array}$ & $\begin{array}{c}\text { Vocábulos } \\
\text { escritos }\end{array}$ & $\begin{array}{c}\text { Fonemas } \\
\text { pronunciados } \\
\text { com "erro" }\end{array}$ & $\begin{array}{c}\text { Transcrição fonológica correta } \\
\text { franscrição } \\
\text { fonológica } \\
\text { com "erro" }\end{array}$ & /haN/ \\
\hline $\mathrm{m}$ & ham & - & $/ \mathrm{hæm} /$ & \\
\hline
\end{tabular}




\begin{tabular}{|c|c|c|c|c|}
\hline \multicolumn{5}{|c|}{ Sujeito $29-1^{a}$ coleta } \\
\hline $\begin{array}{c}\text { Fonemas } \\
\text { observados }\end{array}$ & $\begin{array}{c}\text { Vocábulos } \\
\text { escritos }\end{array}$ & \begin{tabular}{|c|} 
Fonemas \\
pronunciados \\
com "erro"
\end{tabular} & Transcrição fonológica correta & $\begin{array}{l}\text { Transcrição } \\
\text { fonológica } \\
\text { com "erro" }\end{array}$ \\
\hline$d$ & red & dI & /red/ & /'redI/ \\
\hline k & thick & nk & /OIk/ & /tink/ \\
\hline$v$ & of & $f$ & $\begin{array}{c}\text { /a:v/ (AmE) - /Dv/ (BrE) (strong forms) } \\
\text { /əv/ (weak form) }\end{array}$ & $/ \mathrm{dof} /$ \\
\hline \multirow{5}{*}{ I } & useful & $\mathrm{w}$ & /ju:sfəl/, /lju:sful/ & /ju:sfow/ \\
\hline & whole & - & /houl/ (AmE) - /həul// (BrE) & /hou/ \\
\hline & sole & - & /soul/ (AmE) - /səul/ (BrE) & /sou/ \\
\hline & oil & U & /OIl/ & /Uou/ \\
\hline & foil & $U$ & /forl/ & /'fuiəu/ \\
\hline $\mathrm{m}$ & ham & - & /hæm/ & /raN/ \\
\hline
\end{tabular}

\begin{tabular}{|c|c|c|c|c|}
\hline \multicolumn{5}{|c|}{ Suieito $29-2^{a}$ coleta } \\
\hline $\begin{array}{c}\text { Fonemas } \\
\text { observados }\end{array}$ & $\begin{array}{l}\text { Vocábulos } \\
\text { escritos }\end{array}$ & \begin{tabular}{|c|} 
Fonemas \\
pronunciados \\
com "erro"
\end{tabular} & Transcrição fonológica correta & $\begin{array}{l}\text { Transcrição } \\
\text { fonológica } \\
\text { com "erro" }\end{array}$ \\
\hline $\mathrm{v}$ & of & $f$ & $\begin{array}{c}\text { /a:v/ (AmE) - /Dv/ (BrE) (strong forms) } \\
/ \text { /əv/ (weak form) }\end{array}$ & $/ \mathrm{dof} /$ \\
\hline $\mathrm{m}$ & ham & - & /hæm/ & /raN/ \\
\hline
\end{tabular}




\begin{tabular}{|c|c|c|c|c|}
\hline \multicolumn{5}{|c|}{ Sujeito $30-1^{a}$ coleta } \\
\hline $\begin{array}{c}\text { Fonemas } \\
\text { observados }\end{array}$ & $\begin{array}{c}\text { Vocábulos } \\
\text { escritos }\end{array}$ & \begin{tabular}{|c|} 
Fonemas \\
pronunciados \\
com "erro" \\
\end{tabular} & Transcrição fonológica correta & $\begin{array}{l}\text { Transcrição } \\
\text { fonológica } \\
\text { com "erro" }\end{array}$ \\
\hline $\mathrm{t}$ & white & tI & /wart/ & /war'tr/ \\
\hline k & book & kI & /buk/ & /'bu:kI/ \\
\hline \multirow[t]{2}{*}{$\mathrm{v}$} & of & $f$ & $\begin{array}{c}\text { /a:v/ (AmE) - /ov/ (BrE) (strong forms) } \\
/ \partial v / \text { (weak form) }\end{array}$ & $/ \mathrm{pf} /$ \\
\hline & olive & - & /a:liv/ (AmE) - /'oliv/ (BrE) & /'olivi/ \\
\hline \multirow{5}{*}{ I } & useful & $\mathrm{w}$ & /lju:sfəl/, /lju:sful/ & l'ju:sfuw/ \\
\hline & whole & II & /houl/ (AmE) - /həul/ (BrE) & /houli/ \\
\hline & sole & - & /soul/ (AmE) - /səul/ (BrE) & /sou/ \\
\hline & oil & U & /OIl/ & /อIU/ \\
\hline & foil & $U$ & /fərl/ & /'fэiU/ \\
\hline $\mathrm{m}$ & ham & - & /hæm/ & /haN/ \\
\hline $\mathrm{n}$ & ten & - & /ten/ & /teiN/ \\
\hline
\end{tabular}

\begin{tabular}{|c|c|c|c|c|}
\hline \multicolumn{5}{|c|}{ Sujeito $30-2^{a}$ coleta } \\
\hline $\begin{array}{c}\text { Fonemas } \\
\text { observados }\end{array}$ & $\begin{array}{l}\text { Vocábulos } \\
\text { escritos }\end{array}$ & $\begin{array}{c}\text { Fonemas } \\
\text { pronunciados } \\
\text { com "erro" }\end{array}$ & Transcrição fonológica correta & $\begin{array}{l}\text { Transcrição } \\
\text { fonológica } \\
\text { com "erro" }\end{array}$ \\
\hline $\mathrm{k}$ & book & kI & /buk/ & /'bu:kI/ \\
\hline $\mathrm{v}$ & of & $f$ & $\begin{array}{c}\text { /a:v/ (AmE) - /Dv/ (BrE) (strong forms) } \\
/ \text { /əv/ (weak form) }\end{array}$ & $/ \mathrm{pf} /$ \\
\hline $\mathrm{n}$ & ten & & /ten/ & /teiN/ \\
\hline
\end{tabular}




\begin{tabular}{|c|c|c|c|c|}
\hline \multicolumn{5}{|c|}{ Sujeito $31-1^{a}$ coleta } \\
\hline $\begin{array}{c}\text { Fonemas } \\
\text { observados }\end{array}$ & $\begin{array}{l}\text { Vocábulos } \\
\text { escritos }\end{array}$ & \begin{tabular}{|c|} 
Fonemas \\
pronunciados \\
com "erro"
\end{tabular} & Transcrição fonológica correta & $\begin{array}{l}\text { Transcrição } \\
\text { fonológica } \\
\text { com "erro" }\end{array}$ \\
\hline \multirow[t]{2}{*}{$\mathrm{t}$} & light & $\mathrm{tI}$ & /lait/ & /larltis/ \\
\hline & white & tI & /wart/ & /waI'tr/ \\
\hline I & useful & $\mathrm{w}$ & /lju:sfəl/, /lju:sful/ & /ju:sfuw/ \\
\hline $\mathrm{m}$ & some & $\mathrm{mI}$ & /s^m/ (strong form) - /səm/ (weak form) & /səlmI/ \\
\hline $\mathrm{n}$ & wine & $\mathrm{nI}$ & /wain/ & /wai'nI/ \\
\hline
\end{tabular}

\begin{tabular}{|c|c|c|c|c|}
\hline \multicolumn{5}{|c|}{ Sujeito $31-2^{a}$ coleta } \\
\hline $\begin{array}{c}\text { Fonemas } \\
\text { observados }\end{array}$ & $\begin{array}{l}\text { Vocábulos } \\
\text { escritos }\end{array}$ & \begin{tabular}{|c|} 
Fonemas \\
pronunciados \\
com "erro"
\end{tabular} & Transcrição fonológica correta & $\begin{array}{l}\text { Transcrição } \\
\text { fonológica } \\
\text { com "erro" }\end{array}$ \\
\hline $\mathrm{n}$ & wine & $\mathrm{nI}$ & /wain/ & /wai'nI/ \\
\hline
\end{tabular}




\begin{tabular}{|c|c|c|c|c|}
\hline \multicolumn{5}{|c|}{ Sujeito $32-1^{a}$ coleta } \\
\hline $\begin{array}{c}\text { Fonemas } \\
\text { observados }\end{array}$ & $\begin{array}{l}\text { Vocábulos } \\
\text { escritos }\end{array}$ & \begin{tabular}{|c|} 
Fonemas \\
pronunciados \\
com "erro"
\end{tabular} & Transcrição fonológica correta & $\begin{array}{l}\text { Transcrição } \\
\text { fonológica } \\
\text { com "erro" }\end{array}$ \\
\hline $\mathrm{t}$ & hot & tI & /ha:t/ (AmE) - /hot/ (BrE) & /'hoti/ \\
\hline $\mathrm{k}$ & thick & $\mathrm{nk}$ & /OIk/ & /tink/ \\
\hline \multirow{5}{*}{ I } & useful & w & /lju:sfəl/, /ju:sful/ & /ju:sfuw/ \\
\hline & whole & II & /houl/ (AmE) - /həul/ (BrE) & /'rouli/ \\
\hline & sole & - & /soul/ (AmE) - /səul/ (BrE) & /sou/ \\
\hline & oil & $U$ & /OII/ & /OIU/ \\
\hline & foil & U & /fərl/ & /foru/ \\
\hline$m$ & ham & - & /hæm/ & /haN/ \\
\hline $\mathrm{n}$ & ten & - & /ten/ & /teiN/ \\
\hline $\mathrm{n}$ & wine & $\mathrm{nI}$ & /wain/ & /'waini/ \\
\hline
\end{tabular}

\begin{tabular}{|c|c|c|c|c|}
\hline \multicolumn{7}{|c|}{ Sujeito 32-2 $\mathbf{2}^{2}$ coleta } & $\begin{array}{c}\text { Transcrição } \\
\text { fonológica } \\
\text { com "erro" }\end{array}$ \\
\hline $\begin{array}{c}\text { Fonemas } \\
\text { observados }\end{array}$ & $\begin{array}{c}\text { Vocábulos } \\
\text { escritos }\end{array}$ & $\begin{array}{c}\text { Fonemas } \\
\text { pronunciados } \\
\text { com "erro" }\end{array}$ & Transcrição fonológica correta & /haN/ \\
\hline $\mathrm{m}$ & ham & - & $/ \mathrm{hæm} /$ & \\
\hline
\end{tabular}




\begin{tabular}{|c|c|c|c|c|}
\hline \multicolumn{5}{|c|}{ Sujeito $33-1^{a}$ coleta } \\
\hline $\begin{array}{c}\text { Fonemas } \\
\text { observados }\end{array}$ & $\begin{array}{l}\text { Vocábulos } \\
\text { escritos }\end{array}$ & \begin{tabular}{|c|} 
Fonemas \\
pronunciados \\
com "erro"
\end{tabular} & Transcrição fonológica correta & $\begin{array}{l}\text { Transcrição } \\
\text { fonológica } \\
\text { com "erro" }\end{array}$ \\
\hline $\mathrm{t}$ & hot & $\mathrm{tI}$ & /ha:t/ (AmE) - /hot/ (BrE) & /'hoti/ \\
\hline$v$ & of & $f$ & $\begin{array}{c}\text { /a:v/ (AmE) - /Dv/ (BrE) (strong forms) } \\
\text { /əv/ (weak form) }\end{array}$ & $/ \mathrm{pf} /$ \\
\hline \multirow[t]{2}{*}{ I } & whole & lə & /houl/ (AmE) - /həul/ (BrE) & /'houlə/ \\
\hline & sole & - & /soul/ (AmE) - /səul/ (BrE) & /sou/ \\
\hline $\mathrm{m}$ & ham & - & /hæm/ & /haN/ \\
\hline
\end{tabular}

\begin{tabular}{|c|c|c|c|c|}
\hline \multicolumn{2}{|c|}{ Sujeito 33-2 $\mathbf{2}^{\text {a coleta }}$} \\
$\begin{array}{c}\text { Fonemas } \\
\text { observados }\end{array}$ & $\begin{array}{c}\text { Vocábulos } \\
\text { escritos }\end{array}$ & $\begin{array}{c}\text { Fonemas } \\
\text { pronunciados } \\
\text { com "erro" }\end{array}$ & Transcrição fonológica correta & $\begin{array}{c}\text { Transcrição } \\
\text { fonológica } \\
\text { com "erro" }\end{array}$ \\
\hline & & & & \\
\hline
\end{tabular}




\begin{tabular}{|c|c|c|c|c|}
\hline \multicolumn{5}{|c|}{ Sujeito $34-1^{a}$ coleta } \\
\hline $\begin{array}{c}\text { Fonemas } \\
\text { observados }\end{array}$ & $\begin{array}{l}\text { Vocábulos } \\
\text { escritos }\end{array}$ & $\begin{array}{c}\text { Fonemas } \\
\text { pronunciados } \\
\text { com "erro" }\end{array}$ & Transcrição fonológica correta & $\begin{array}{l}\text { Transcrição } \\
\text { fonológica } \\
\text { com "erro" }\end{array}$ \\
\hline $\mathrm{v}$ & of & $f$ & $\begin{array}{c}\text { /a:v/ (AmE) - /Dv/ (BrE) (strong forms) } \\
\text { /əv/ (weak form) }\end{array}$ & $/ \mathrm{pf} /$ \\
\hline \multirow{5}{*}{ I } & useful & $\mathrm{w}$ & /'ju:sfəl/, /lju:sful/ & /ju:sfuw/ \\
\hline & whole & II & /houl/ (AmE) - /həul/ (BrE) & /houlı/ \\
\hline & sole & - & /soul/ (AmE) - /səul/ (BrE) & /sou/ \\
\hline & oil & U & /วIl/ & /כIU/ \\
\hline & foil & $U$ & /forl/ & /foIU/ \\
\hline $\mathrm{m}$ & ham & - & /hæm/ & /haN/ \\
\hline
\end{tabular}

\begin{tabular}{|c|c|c|c|c|}
\hline \multicolumn{5}{|c|}{ Sujeito $34-2^{a}$ coleta } \\
\hline $\begin{array}{l}\text { Fonemas } \\
\text { observados }\end{array}$ & $\begin{array}{l}\text { Vocábulos } \\
\text { escritos }\end{array}$ & $\begin{array}{c}\text { Fonemas } \\
\text { pronunciados } \\
\text { com "erro" }\end{array}$ & Transcrição fonológica correta & $\begin{array}{l}\text { Transcrição } \\
\text { fonológica } \\
\text { com "erro" }\end{array}$ \\
\hline $\mathrm{v}$ & of & $f$ & $\begin{array}{c}\text { /a:v/ (AmE) - /Dv/ (BrE) (strong forms) } \\
\text { /əv/ (weak form) }\end{array}$ & $/ \mathrm{pf} /$ \\
\hline
\end{tabular}




\begin{tabular}{|c|c|c|c|c|}
\hline \multicolumn{5}{|c|}{ Sujeito $35-1^{a}$ coleta } \\
\hline $\begin{array}{c}\text { Fonemas } \\
\text { observados }\end{array}$ & $\begin{array}{l}\text { Vocábulos } \\
\text { escritos }\end{array}$ & \begin{tabular}{|c|} 
Fonemas \\
pronunciados \\
com "erro"
\end{tabular} & Transcrição fonológica correta & $\begin{array}{l}\text { Transcrição } \\
\text { fonológica } \\
\text { com "erro" }\end{array}$ \\
\hline \multirow[t]{2}{*}{$t$} & hot & t 5 & /ha:t/ (AmE) - /hnt/ (BrE) & /hot $\int \mathrm{I} /$ \\
\hline & white & tI & /wart/ & /'wartI/ \\
\hline $\mathrm{v}$ & of & $f$ & $\begin{array}{c}\text { /a:v/ (AmE) - /pv/ (BrE) (strong forms) } \\
\text { /əv/ (weak form) }\end{array}$ & $/ \mathrm{dof} /$ \\
\hline \multirow{4}{*}{ I } & useful & w & /'ju:sfəl/, /lju:sful/ & l'ju:zfuw/ \\
\hline & whole & IəU & /houl/ (AmE) - /həul/ (BrE) & /'hãIləu/ \\
\hline & oil & $U$ & /OIl/ & /OIU/ \\
\hline & foil & $U$ & /fכil/ & /foul \\
\hline $\mathrm{m}$ & ham & - & /hæm/ & /haN/ \\
\hline$n$ & wine & $\mathrm{nI}$ & /wain/ & /'wains/ \\
\hline
\end{tabular}

\begin{tabular}{|c|c|c|c|c|}
\hline \multicolumn{5}{|c|}{ Sujeito $35-2^{a}$ coleta } \\
\hline $\begin{array}{c}\text { Fonemas } \\
\text { observados }\end{array}$ & $\begin{array}{c}\text { Vocábulos } \\
\text { escritos }\end{array}$ & $\begin{array}{l}\text { Fonemas } \\
\text { pronunciados } \\
\text { com "erro" }\end{array}$ & Transcrição fonológica correta & $\begin{array}{l}\text { Transcrição } \\
\text { fonológica } \\
\text { com "erro" }\end{array}$ \\
\hline $\mathrm{v}$ & of & $f$ & $\begin{array}{c}\text { /a:v/ (AmE) - /Dv/ (BrE) (strong forms) } \\
/ \text { əəv/ (weak form) }\end{array}$ & /Df/ \\
\hline \multirow[b]{2}{*}{ I } & whole & II & /houl/ (AmE) - /həul/ (BrE) & /'holə/ \\
\hline & useful & w & /'ju:sfəl/, /lju:sful/ & /ju:zfuw/ \\
\hline $\mathrm{m}$ & ham & - & /hæm/ & /haN/ \\
\hline $\mathrm{n}$ & wine & $\mathrm{nI}$ & /wain/ & /'waini/ \\
\hline
\end{tabular}




\begin{tabular}{|c|c|c|c|c|}
\hline \multicolumn{5}{|c|}{ Sujeito $36-1^{a}$ coleta } \\
\hline $\begin{array}{c}\text { Fonemas } \\
\text { observados }\end{array}$ & $\begin{array}{l}\text { Vocábulos } \\
\text { escritos }\end{array}$ & $\begin{array}{l}\text { Fonemas } \\
\text { pronunciados } \\
\text { com "erro" }\end{array}$ & Transcrição fonológica correta & $\begin{array}{l}\text { Transcrição } \\
\text { fonológica } \\
\text { com "erro" }\end{array}$ \\
\hline $\mathrm{t}$ & eight & tI & /eit/ & /'erti/ \\
\hline $\mathrm{v}$ & of & $f$ & $\begin{array}{c}\text { /a:v/ (AmE) - /Dv/ (BrE) (strong forms) } \\
\text { /əv/ (weak form) }\end{array}$ & $/ \mathrm{dof} /$ \\
\hline \multirow[t]{4}{*}{ I } & useful & w & /'ju:sfəl/, /'ju:sful/ & lju:zfow/ \\
\hline & whole & lə & /houl/ (AmE) - /həul/ (BrE) & /'houlə/ \\
\hline & oil & U & /Oil/ & /วIU/ \\
\hline & foil & $U$ & /fכil/ & /forU/ \\
\hline $\mathrm{m}$ & ham & - & /hæm/ & /haN/ \\
\hline
\end{tabular}

\begin{tabular}{|c|c|c|c|c|}
\hline \multicolumn{5}{|c|}{ Sujeito $36-2^{a}$ coleta } \\
\hline $\begin{array}{c}\text { Fonemas } \\
\text { observados }\end{array}$ & $\begin{array}{l}\text { Vocábulos } \\
\text { escritos }\end{array}$ & \begin{tabular}{|c|} 
Fonemas \\
pronunciados \\
com "erro"
\end{tabular} & Transcrição fonológica correta & $\begin{array}{l}\text { Transcrição } \\
\text { fonológica } \\
\text { com "erro" }\end{array}$ \\
\hline $\mathrm{v}$ & of & $f$ & $\begin{array}{c}\text { /a:v/ (AmE) - /ov/ (BrE) (strong forms) } \\
/ \partial v / \text { (weak form) }\end{array}$ & $/ \mathrm{dof} /$ \\
\hline I & useful & $\bar{w}$ & /lju:sfəl/, /lju:sful/ & l'ju:zfow/ \\
\hline $\mathrm{m}$ & ham & | & /hæm/ & /haN/ \\
\hline
\end{tabular}




\begin{tabular}{|c|c|c|c|c|}
\hline \multicolumn{5}{|c|}{ Sujeito $37-1^{a}$ coleta } \\
\hline $\begin{array}{c}\text { Fonemas } \\
\text { observados }\end{array}$ & $\begin{array}{c}\text { Vocábulos } \\
\text { escritos }\end{array}$ & \begin{tabular}{|c|} 
Fonemas \\
pronunciados \\
com "erro" \\
\end{tabular} & Transcrição fonológica correta & $\begin{array}{l}\text { Transcrição } \\
\text { fonológica } \\
\text { com "erro" }\end{array}$ \\
\hline $\mathrm{t}$ & white & tI & /wart/ & /'waiti/ \\
\hline g & bag & gI & /bæg/ & /'bægi/ \\
\hline $\mathrm{v}$ & of & $f$ & $\begin{array}{c}\text { /a:v/ (AmE) - /Dv/ (BrE) (strong forms) } \\
\text { /əv/ (weak form) }\end{array}$ & $/ \mathrm{dof} /$ \\
\hline \multirow{5}{*}{ I } & useful & $\mathrm{w}$ & /'ju:sfəl/, /'ju:sful/ & /'u:zfuw/ \\
\hline & whole & II & /houl/ (AmE) - /həul/ (BrE) & /'houli/ \\
\hline & sole & - & /soul/ (AmE) - /səul/ (BrE) & /sou/ \\
\hline & oil & $U$ & /OIl/ & /OIU/ \\
\hline & foil & $\bar{U}$ & /forl/ & /ford/ \\
\hline $\mathrm{m}$ & ham & - & /hæm/ & /haN/ \\
\hline $\mathrm{n}$ & wine & $\mathrm{nI}$ & /wain/ & /'wains/ \\
\hline
\end{tabular}

\begin{tabular}{|c|c|c|c|c|}
\hline \multicolumn{5}{|c|}{ Sujeito $37-2^{a}$ coleta } \\
\hline $\begin{array}{c}\text { Fonemas } \\
\text { observados }\end{array}$ & $\begin{array}{l}\text { Vocábulos } \\
\text { escritos }\end{array}$ & \begin{tabular}{|c|} 
Fonemas \\
pronunciados \\
com "erro" \\
\end{tabular} & Transcrição fonológica correta & $\begin{array}{l}\text { Transcrição } \\
\text { fonológica } \\
\text { com "erro" }\end{array}$ \\
\hline $\mathrm{t}$ & white & tI & /wart/ & /'wartI/ \\
\hline $\mathrm{k}$ & book & $\mathrm{kI}$ & /buk/ & /bu'ks/ \\
\hline $\mathrm{v}$ & of & $f$ & $\begin{array}{c}\text { /a:v/ (AmE) - /Dv/ (BrE) (strong forms) } \\
\text { /əv/ (weak form) }\end{array}$ & $/ \mathrm{dof} /$ \\
\hline \multirow[t]{2}{*}{ I } & useful & w & /l'ju:sfəl/, /lju:sful/ & /lu:zfuw/ \\
\hline & foil & U & /forl/ & /forU/ \\
\hline $\mathrm{m}$ & ham & - & /hæm/ & /haN/ \\
\hline$n$ & wine & $\mathrm{nI}$ & /wain/ & /'waini/ \\
\hline
\end{tabular}




\begin{tabular}{|c|c|c|c|c|}
\hline \multicolumn{5}{|c|}{ Sujeito $38-1^{a}$ coleta } \\
\hline $\begin{array}{l}\text { Fonemas } \\
\text { observados }\end{array}$ & $\begin{array}{l}\text { Vocábulos } \\
\text { escritos }\end{array}$ & \begin{tabular}{|c|} 
Fonemas \\
pronunciados \\
com "erro"
\end{tabular} & Transcrição fonológica correta & $\begin{array}{l}\text { Transcrição } \\
\text { fonológica } \\
\text { com "erro" }\end{array}$ \\
\hline \multirow{3}{*}{ I } & useful & w & /'ju:sfəl/, /lju:sful/ & /'ju:sfow/ \\
\hline & oil & $\bar{U}$ & /วIl/ & /כIU/ \\
\hline & foil & $U$ & /fərl/ & /forU/ \\
\hline$m$ & ham & - & /hæm/ & /haN/ \\
\hline
\end{tabular}

\begin{tabular}{|c|c|c|c|c|}
\hline \multicolumn{2}{|c|}{ Sujeito 38 - 2 $\mathbf{2}$ coleta } & $\begin{array}{c}\text { Transcrição } \\
\text { fonológica } \\
\text { com "erro" }\end{array}$ \\
\hline $\begin{array}{c}\text { Fonemas } \\
\text { observados }\end{array}$ & $\begin{array}{c}\text { Vocábulos } \\
\text { escritos }\end{array}$ & $\begin{array}{c}\text { Fonemas } \\
\text { pronunciados } \\
\text { com "erro" }\end{array}$ & Transcrição fonológica correta & \\
\hline & & & & \\
\hline
\end{tabular}




\begin{tabular}{|c|c|c|c|c|}
\hline \multicolumn{5}{|c|}{ Sujeito $39-1^{a}$ coleta } \\
\hline $\begin{array}{c}\text { Fonemas } \\
\text { observados }\end{array}$ & $\begin{array}{c}\text { Vocábulos } \\
\text { escritos }\end{array}$ & $\begin{array}{c}\text { Fonemas } \\
\text { pronunciados } \\
\text { com "erro" }\end{array}$ & Transcrição fonológica correta & $\begin{array}{c}\text { Transcrição fonológica } \\
\text { com "erro" }\end{array}$ \\
\hline $\mathrm{v}$ & of & $f$ & $\begin{array}{c}\text { /a:v/ (AmE) - /ov/ (BrE) (strong forms) } \\
/ \text { /əv/ (weak form) }\end{array}$ & $/ \mathrm{pf} /$ \\
\hline \multirow{5}{*}{ I } & useful & - & /lju:sfəl/, /lju:sful/ & /lju:sful \\
\hline & whole & II & /houl/ (AmE) - /həul/ (BrE) & /houli/ \\
\hline & sole & - & /soul/ (AmE) - /səul/ (BrE) & /sou/ \\
\hline & oil & $U$ & /OIl/ & /วIU/ \\
\hline & foil & $\bar{U}$ & /forl/ & /foiv/ \\
\hline$m$ & ham & - & /hæm/ & /raN/ \\
\hline
\end{tabular}

\begin{tabular}{|c|c|c|c|c|}
\hline \multicolumn{5}{|c|}{ Sujeito $39-2^{a}$ coleta } \\
\hline $\begin{array}{c}\text { Fonemas } \\
\text { observados }\end{array}$ & $\begin{array}{l}\text { Vocábulos } \\
\text { escritos }\end{array}$ & \begin{tabular}{|c} 
Fonemas \\
pronunciados \\
com "erro"
\end{tabular} & Transcrição fonológica correta & $\begin{array}{c}\text { Transcrição fonológica } \\
\text { com "erro" }\end{array}$ \\
\hline $\mathrm{v}$ & of & $f$ & $\begin{array}{c}\text { /a:v/ (AmE) - /ov/ (BrE) (strong forms) } \\
\text { /əv/ (weak form) }\end{array}$ & $/ \mathrm{pf} /$ \\
\hline \multirow[t]{2}{*}{ I } & whole & II & /houl/ (AmE) - /həul/ (BrE) & /'houli/ \\
\hline & foil & U & /forl/ & /foru/ \\
\hline \multirow[t]{2}{*}{$\mathrm{m}$} & some & $\mathrm{mI}$ & /s^m/ (strong form) - /səm/ (weak form) & /so'mI/ \\
\hline & ham & - & /hæm/ & /haN/ \\
\hline
\end{tabular}




\begin{tabular}{|c|c|c|c|c|}
\hline \multicolumn{5}{|c|}{ Sujeito $40-1^{a}$ coleta } \\
\hline $\begin{array}{l}\text { Fonemas } \\
\text { observados }\end{array}$ & $\begin{array}{l}\text { Vocábulos } \\
\text { escritos }\end{array}$ & \begin{tabular}{|c} 
Fonemas \\
pronunciados \\
com "erro"
\end{tabular} & Transcrição fonológica correta & $\begin{array}{l}\text { Transcrição } \\
\text { fonológica } \\
\text { com "erro" }\end{array}$ \\
\hline $\mathrm{v}$ & of & $f$ & $\begin{array}{c}\text { /a:v/ (AmE) - /pv/ (BrE) (strong forms) } \\
/ \text { /əv/ (weak form) }\end{array}$ & $/ \mathrm{df} /$ \\
\hline \multirow[t]{4}{*}{1} & useful & w & /lju:sfəl/, /lju:sful/ & /ju:zfuw/ \\
\hline & whole & lə & /houl/ (AmE) - /həul/ (BrE) & /'houle/ \\
\hline & oil & $\bar{U}$ & /orl/ & /OIU/ \\
\hline & foil & $\bar{U}$ & /forl/ & /foIU/ \\
\hline$m$ & ham & - & /hæm/ & /haN/ \\
\hline
\end{tabular}

\begin{tabular}{|c|c|c|c|c|}
\hline \multicolumn{5}{|c|}{ Sujeito $40-2^{a}$ coleta } \\
\hline $\begin{array}{l}\text { Fonemas } \\
\text { observados }\end{array}$ & $\begin{array}{l}\text { Vocábulos } \\
\text { escritos }\end{array}$ & $\begin{array}{c}\text { Fonemas } \\
\text { pronunciados } \\
\text { com "erro" }\end{array}$ & Transcrição fonológica correta & $\begin{array}{l}\text { Transcrição } \\
\text { fonológica } \\
\text { com "erro" }\end{array}$ \\
\hline $\mathrm{v}$ & of & $\mathrm{f}$ & $\begin{array}{c}\text { /a:v/ (AmE) - /pv/ (BrE) (strong forms) } \\
/ \text { /əv/ (weak form) }\end{array}$ & $/ \mathrm{pf} /$ \\
\hline
\end{tabular}




\begin{tabular}{|c|c|c|c|c|}
\hline \multicolumn{5}{|c|}{ Sujeito $41-1^{a}$ coleta } \\
\hline $\begin{array}{l}\text { Fonemas } \\
\text { observados }\end{array}$ & $\begin{array}{l}\text { Vocábulos } \\
\text { escritos }\end{array}$ & \begin{tabular}{|c|} 
Fonemas \\
pronunciados \\
com "erro"
\end{tabular} & Transcrição fonológica correta & $\begin{array}{l}\text { Transcrição } \\
\text { fonológica } \\
\text { com "erro" }\end{array}$ \\
\hline \multirow[t]{2}{*}{$\mathrm{t}$} & hot & tI & /ha:t/ (AmE) - /hot/ (BrE) & $/ \mathrm{ho}^{\mathrm{l}} \mathrm{tI} /$ \\
\hline & pot & tI & /pa:t/ (AmE) - /ppt/ (BrE) & /'poti/ \\
\hline$g$ & bag & gI & /bæg/ & /bæ'gi/ \\
\hline $\mathrm{v}$ & of & $f$ & $\begin{array}{c}\text { /a:v/ (AmE) - /Dv/ (BrE) (strong forms) } \\
\text { /əv/ (weak form) }\end{array}$ & /pf/ \\
\hline \multirow[t]{4}{*}{$\mathrm{I}$} & useful & w & /'ju:sfəl/, /'ju:sful/ & l'ju:zfuw/ \\
\hline & whole & II & /houl/ (AmE) - /həul/ (BrE) & /'rouli/ \\
\hline & oil & $U$ & /OIl/ & /OIU/ \\
\hline & foil & $U$ & /fכIl/ & /foiv/ \\
\hline $\mathrm{n}$ & wine & $\mathrm{nI}$ & /wain/ & /'waini/ \\
\hline
\end{tabular}

\begin{tabular}{|c|c|c|c|c|}
\hline \multicolumn{5}{|c|}{ Sujeito $41-2^{a}$ coleta } \\
\hline $\begin{array}{l}\text { Fonemas } \\
\text { observados }\end{array}$ & $\begin{array}{c}\text { Vocábulos } \\
\text { escritos }\end{array}$ & $\begin{array}{l}\text { Fonemas } \\
\text { pronunciados } \\
\text { com "erro" }\end{array}$ & Transcrição fonológica correta & $\begin{array}{l}\text { Transcrição } \\
\text { fonológica } \\
\text { com "erro" }\end{array}$ \\
\hline $\mathrm{t}$ & white & tI & /wart/ & /'waItI/ \\
\hline g & bag & gI & /bæg/ & /bæ'gi/ \\
\hline $\mathrm{v}$ & of & $f$ & $\begin{array}{c}\text { /a:v/ (AmE) - /Dv/ (BrE) (strong forms) } \\
\text { /əv/ (weak form) }\end{array}$ & $/ \mathrm{pf} /$ \\
\hline l & useful & w & /lju:sfəl/, /'ju:sful/ & /ju:zfuw/ \\
\hline $\mathrm{n}$ & wine & nI & /wain/ & /'wainI/ \\
\hline
\end{tabular}

Sujeito $42-1^{a}$ coleta 


\begin{tabular}{|c|c|c|c|c|}
\hline $\begin{array}{c}\text { Fonemas } \\
\text { observados }\end{array}$ & $\begin{array}{c}\text { Vocábulos } \\
\text { escritos }\end{array}$ & $\begin{array}{c}\text { Fonemas } \\
\text { pronunciados } \\
\text { com "erro" }\end{array} \mid$ & Transcrição fonológica correta & $\begin{array}{l}\text { Transcrição } \\
\text { fonológica } \\
\text { com "erro" }\end{array}$ \\
\hline \multirow[t]{3}{*}{$\mathrm{t}$} & pot & $\mathrm{tI}$ & /pa:t/ (AmE) - /ppt/ (BrE) & /'poti/ \\
\hline & hot & $\mathrm{tI}$ & /ha:t/ (AmE) - /hbt/ (BrE) & /'hotI/ \\
\hline & white & $\mathrm{tI}$ & /wart/ & /'waiti/ \\
\hline 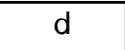 & red & dI & $/ \mathrm{red} /$ & /'RedI/ \\
\hline $\mathrm{v}$ & of & $f$ & $\begin{array}{c}\text { /a:v/ (AmE) - /pv/ (BrE) (strong forms) } \\
\text { /əv/ (weak form) }\end{array}$ & $/ \mathrm{pf} /$ \\
\hline \multirow[t]{5}{*}{$\mathrm{I}$} & useful & w & /lju:sfəl/, /lju:sful/ & /ju:sfow/ \\
\hline & whole & lə & /houl/ (AmE) - /həul/ (BrE) & /'houlə/ \\
\hline & sole & lə & /soul/ (AmE) - /səul/ (BrE) & /solle/ \\
\hline & oil & U & /OIl/ & /כIU/ \\
\hline & foil & U & /forl/ & /forU/ \\
\hline $\mathrm{m}$ & ham & - & /hæm/ & /haN/ \\
\hline $\mathrm{n}$ & wine & $\mathrm{nI}$ & /wain/ & /'wains/ \\
\hline
\end{tabular}

\begin{tabular}{|c|c|c|c|c|}
\hline \multicolumn{5}{|c|}{ Sujeito $42-2^{a}$ coleta } \\
\hline $\begin{array}{l}\text { Fonemas } \\
\text { observados }\end{array}$ & $\begin{array}{l}\text { Vocábulos } \\
\text { escritos }\end{array}$ & \begin{tabular}{|c|} 
Fonemas \\
pronunciados \\
com "erro"
\end{tabular} & Transcrição fonológica correta & $\begin{array}{l}\text { Transcrição } \\
\text { fonológica } \\
\text { com "erro" }\end{array}$ \\
\hline $\mathrm{v}$ & of & $f$ & $\begin{array}{c}\text { /a:v/ (AmE) - / } \mathrm{Dv} /(\mathrm{BrE}) \text { (strong forms) } \\
/ \text { /əv/ (weak form) }\end{array}$ & $/ \mathrm{dof} /$ \\
\hline \multirow{3}{*}{ I } & useful & $\mathrm{w}$ & /'ju:sfəl/, /'ju:sful/ & l'ju:zfow/ \\
\hline & oil & $U$ & /OIl/ & /ОIU/ \\
\hline & foil & $U$ & /fכIl/ & /forU/ \\
\hline $\mathrm{m}$ & ham & - & /hæm/ & /haN/ \\
\hline $\mathrm{n}$ & wine & $\mathrm{nI}$ & /wain/ & /'waini/ \\
\hline
\end{tabular}




\begin{tabular}{|c|c|c|c|c|}
\hline \multicolumn{5}{|c|}{ Sujeito $43-1^{a}$ coleta } \\
\hline $\begin{array}{l}\text { Fonemas } \\
\text { observados }\end{array}$ & $\begin{array}{l}\text { Vocábulos } \\
\text { escritos }\end{array}$ & $\begin{array}{l}\text { Fonemas } \\
\text { pronunciados } \\
\text { com "erro" }\end{array}$ & Transcrição fonológica correta & $\begin{array}{l}\text { Transcrição } \\
\text { fonológica } \\
\text { com "erro" }\end{array}$ \\
\hline $\mathrm{v}$ & of & $f$ & $\begin{array}{c}\text { /a:v/ (AmE) - /Dv/ (BrE) (strong forms) } \\
/ \text { /əv/ (weak form) }\end{array}$ & $/ \mathrm{Df} /$ \\
\hline \multirow{5}{*}{ I } & useful & w & /lju:sfəl/, /lju:sful/ & /ju:zfuw/ \\
\hline & whole & lə & /houl/ (AmE) - /həul/ (BrE) & /'houlə/ \\
\hline & sole & lə & /soul/ (AmE) - /səul/ (BrE) & /'soulə/ \\
\hline & oil & $U$ & /OIl/ & /OIU/ \\
\hline & foil & $U$ & /fərl/ & /foiv/ \\
\hline $\mathrm{m}$ & ham & - & /hæm/ & /haN/ \\
\hline
\end{tabular}

\begin{tabular}{|c|c|c|c|c|}
\hline \multicolumn{2}{|c|}{ Sujeito 43 - 2 coleta } \\
\hline $\begin{array}{c}\text { Fonemas } \\
\text { observados }\end{array}$ & $\begin{array}{c}\text { Vocábulos } \\
\text { escritos }\end{array}$ & $\begin{array}{c}\text { Fonemas } \\
\text { pronunciados } \\
\text { com "erro" }\end{array}$ & Transcrição fonológica correta & $\begin{array}{c}\text { Transcrição } \\
\text { fonológica } \\
\text { com "erro" }\end{array}$ \\
\hline $\mathrm{v}$ & of & $\mathrm{f}$ & /a:v/ (AmE) - /Dv/ (BrE) (strong forms) & /Df/ \\
\hline $\mathrm{I}$ & useful & $\mathrm{w}$ & /əv/ (weak form) & /lju:sfəl/, /lju:sful/ \\
\hline
\end{tabular}




\begin{tabular}{|c|c|c|c|c|}
\hline \multicolumn{5}{|c|}{ Sujeito $44-1^{a}$ coleta } \\
\hline $\begin{array}{c}\text { Fonemas } \\
\text { observados }\end{array}$ & $\begin{array}{l}\text { Vocábulos } \\
\text { escritos }\end{array}$ & \begin{tabular}{|c|} 
Fonemas \\
pronunciados \\
com "erro"
\end{tabular} & Transcrição fonológica correta & $\begin{array}{l}\text { Transcrição } \\
\text { fonológica } \\
\text { com "erro" }\end{array}$ \\
\hline $\mathrm{t}$ & hot & $\mathrm{tI}$ & /ha:t/ (AmE) - /hot/ (BrE) & /'hotI/ \\
\hline $\mathrm{v}$ & of & $f$ & $\begin{array}{c}\text { /a:v/ (AmE) - /Dv/ (BrE) (strong forms) } \\
\text { /əv/ (weak form) }\end{array}$ & $/ \mathrm{pf} /$ \\
\hline \multirow[t]{2}{*}{$r$} & sure & rI & 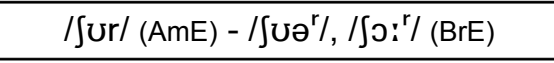 & /sə'rI/ \\
\hline & pure & rI & /pjur/ (AmE) - /pjuər/, /pjo:'/ (BrE) & /pã'rı/ \\
\hline \multirow{5}{*}{ I } & useful & w & /'ju:sfal/, /lju:sful/ & /ju:sfow/ \\
\hline & whole & II & /houl/ (AmE) - /həul/ (BrE) & /'hulI/ \\
\hline & sole & II & /soul/ (AmE) - /səul/ (BrE) & /'souli/ \\
\hline & oil & U & /OIl/ & loIU/ \\
\hline & foil & U & /forl/ & /foiv/ \\
\hline \multirow[t]{2}{*}{$m$} & some & $\mathrm{mI}$ & /s^m/ (strong form) - /səm/ (weak form) & /sə'mI/ \\
\hline & ham & - & /hæm/ & /raN/ \\
\hline
\end{tabular}

\begin{tabular}{|c|c|c|c|c|}
\hline \multicolumn{5}{|c|}{ Sujeito $44-2^{a}$ coleta } \\
\hline $\begin{array}{c}\text { Fonemas } \\
\text { observados }\end{array}$ & $\begin{array}{l}\text { Vocábulos } \\
\text { escritos }\end{array}$ & \begin{tabular}{|c|} 
Fonemas \\
pronunciados \\
com "erro"
\end{tabular} & Transcrição fonológica correta & $\begin{array}{l}\text { Transcrição } \\
\text { fonológica } \\
\text { com "erro" }\end{array}$ \\
\hline $\mathrm{k}$ & book & $\mathrm{kI}$ & /buk/ & /bu'kI/ \\
\hline $\mathrm{v}$ & of & $f$ & $\begin{array}{c}\text { /a:v/ (AmE) - /pv/ (BrE) (strong forms) } \\
/ \text { /əv/ (weak form) }\end{array}$ & $/ \mathrm{pf} /$ \\
\hline \multirow{4}{*}{ I } & useful & w & /lju:sfəl/, /'ju:sful/ & lju:zfuw/ \\
\hline & whole & II & /houl/ (AmE) - /həul/ (BrE) & /'houli/ \\
\hline & oil & $U$ & /วIl/ & /oIU/ \\
\hline & foil & U & /forl/ & /foiv/ \\
\hline $\mathrm{m}$ & ham & - & /hæm/ & /haN/ \\
\hline
\end{tabular}




\begin{tabular}{|c|c|c|c|c|}
\hline \multicolumn{5}{|c|}{ Sujeito $45-1^{a}$ coleta } \\
\hline $\begin{array}{c}\text { Fonemas } \\
\text { observados }\end{array}$ & $\begin{array}{l}\text { Vocábulos } \\
\text { escritos }\end{array}$ & \begin{tabular}{|c|} 
Fonemas \\
pronunciados \\
com "erro"
\end{tabular} & Transcrição fonológica correta & $\begin{array}{c}\text { Transcrição fonológica } \\
\text { com "erro" }\end{array}$ \\
\hline $\mathrm{t}$ & hot & $\mathrm{tI}$ & /ha:t/ (AmE) - /hbt/ (BrE) & /'hotI/ \\
\hline \multirow[t]{2}{*}{$\mathrm{k}$} & book & $\mathrm{kI}$ & /buk/ & /bu'kI/ \\
\hline & thick & nk & /OIk/ & /tink/ \\
\hline $\mathrm{v}$ & of & $f$ & $\begin{array}{c}\text { /a:v/ (AmE) - /Dv/ (BrE) (strong forms) } \\
\text { /əv/ (weak form) }\end{array}$ & $/ \mathrm{pf} /$ \\
\hline \multirow[t]{2}{*}{$r$} & cure & $\mathrm{rI}$ & /kjur/ (AmE) - /kjuər/, /kjə: $:^{r} /(\mathrm{BrE})$ & /kãN'ri/ \\
\hline & pure & rI & /pjur/ (AmE) - /pjuər/, /pjo: 'r/ (BrE) & /pju'rI/ \\
\hline \multirow{5}{*}{1} & useful & - & /lju:sfəl/, /'ju:sful/ & /ju:sful \\
\hline & whole & lə & /houl/ (AmE) - /həul/ (BrE) & /'houlə/ \\
\hline & sole & - & /soul/ (AmE) - /səul/ (BrE) & /sou/ \\
\hline & oil & II & /OIl/ & /loulı/ \\
\hline & foil & U & /forl/ & /foiv/ \\
\hline $\mathrm{m}$ & ham & - & /hæm/ & /raN/ \\
\hline
\end{tabular}

\begin{tabular}{|c|c|c|c|c|}
\hline \multicolumn{5}{|c|}{ Sujeito $45-2^{a}$ coleta } \\
\hline $\begin{array}{l}\text { Fonemas } \\
\text { observados }\end{array}$ & $\begin{array}{l}\text { Vocábulos } \\
\text { escritos }\end{array}$ & \begin{tabular}{|c|} 
Fonemas \\
pronunciados \\
com "erro"
\end{tabular} & Transcrição fonológica correta & $\begin{array}{c}\text { Transcrição fonológica } \\
\text { com "erro" }\end{array}$ \\
\hline V & of & $f$ & $\begin{array}{c}\text { /a:v/ (AmE) - /Dv/ (BrE) (strong forms) } \\
/ \text { /əv/ (weak form) }\end{array}$ & /of/ \\
\hline $\mathrm{m}$ & ham & - & /hæm/ & /raN/ \\
\hline
\end{tabular}




\section{Anexo F - Tópicos das Aulas de 'Pronúncia da Língua Inglesa'}

\begin{tabular}{|c|c|c|c|}
\hline Tema & Atividade & Local & Duração \\
\hline $\begin{array}{l}\text { Leitura oral do } \\
\text { texto } \\
\text { (Lista de compras) }\end{array}$ & $\begin{array}{l}1^{\text {a }} \text { gravação do texto - sem treino anterior a } \\
\text { gravação. }\end{array}$ & $\begin{array}{l}\text { Laboratório } \\
\text { de Línguas }\end{array}$ & 2 aulas \\
\hline $\begin{array}{l}\text { Alfabeto Fonético } \\
\text { da } \\
\text { Língua Inglesa }\end{array}$ & $\begin{array}{l}\text { Reconhecimento de fonemas semelhantes e } \\
\text { diferentes em ambas às línguas. Os } \\
\text { fonemas consonantais da língua inglesa. }\end{array}$ & $\begin{array}{l}\text { Sala de } \\
\text { aula }\end{array}$ & 2 aulas \\
\hline $\begin{array}{l}\text { Treino de } \\
\text { discriminação } \\
\text { auditiva }\end{array}$ & $\begin{array}{l}\text { A partir de material didático previamente } \\
\text { gravado, houve produção oral dos pares } \\
\text { mínimos dos fonemas consonantais. }\end{array}$ & $\begin{array}{l}\text { Laboratório } \\
\text { de Línguas }\end{array}$ & 2 aulas \\
\hline $\begin{array}{l}\text { As terminações } \\
\text {-S e -ED }\end{array}$ & $\begin{array}{l}\text { A partir da explicação da regra para as três } \\
\text { diferentes realizações da terminação dos } \\
\text { verbos regulares e as três diferentes } \\
\text { realizações da terminação -s do plural dos } \\
\text { substantivos, } 3^{a} \text { pessoa do singular dos } \\
\text { verbos no presente, caso possessivo. }\end{array}$ & $\begin{array}{l}\text { Sala de } \\
\text { aula }\end{array}$ & 2 aulas \\
\hline $\begin{array}{l}\text { Treino e } \\
\text { discriminação } \\
\text { auditiva }\end{array}$ & $\begin{array}{l}\text { A professora incentivou os alunos a } \\
\text { produzirem oralmente as diferenças } \\
\text { existentes para as terminações. }\end{array}$ & $\begin{array}{l}\text { Laboratório } \\
\text { de Línguas }\end{array}$ & 2 aulas \\
\hline $\begin{array}{l}\text { Treino e } \\
\text { discriminação } \\
\text { auditiva }\end{array}$ & $\begin{array}{l}\text { Houve uma série de repetições de diálogos } \\
\text { de material didático gravado por nativos } \\
\text { sobre encontros consonantais. }\end{array}$ & $\begin{array}{l}\text { Laboratório } \\
\text { de Línguas }\end{array}$ & 2 aulas \\
\hline $\begin{array}{l}\text { Alfabeto Fonético } \\
\text { da Língua } \\
\text { Inglesa }\end{array}$ & Os fonemas vocálicos da língua inglesa. & $\begin{array}{l}\text { Sala de } \\
\text { aula }\end{array}$ & 2 aulas \\
\hline $\begin{array}{l}\text { Treino de } \\
\text { discriminação } \\
\text { auditiva }\end{array}$ & $\begin{array}{l}\text { A partir de material didático previamente } \\
\text { gravado, houve produção oral dos pares } \\
\text { mínimos dos fonemas vocálicos. }\end{array}$ & $\begin{array}{l}\text { Laboratório } \\
\text { de Línguas }\end{array}$ & 2 aulas \\
\hline $\begin{array}{l}\text { Contraste } \\
\text { fonético- } \\
\text { fonológico dos } \\
\text { fonemas }\end{array}$ & $\begin{array}{l}\text { Discussão das interferências fonológicas do } \\
\text { português do Brasil durante o aprendizado } \\
\text { da pronúncia do inglês como língua } \\
\text { estrangeira. }\end{array}$ & $\begin{array}{l}\text { Sala de } \\
\text { aula }\end{array}$ & 2 aulas \\
\hline $\begin{array}{l}\text { Treino de } \\
\text { discriminação } \\
\text { auditiva }\end{array}$ & $\begin{array}{l}\text { A partir de material didático previamente } \\
\text { gravado, houve produção oral dos sons das } \\
\text { formas tônicas e átonas nas sentenças e da } \\
\text { união dos vocábulos no discurso. }\end{array}$ & $\begin{array}{l}\text { Laboratório } \\
\text { de Línguas }\end{array}$ & 2 aulas \\
\hline $\begin{array}{l}\text { Treino de } \\
\text { discriminação } \\
\text { auditiva }\end{array}$ & $\begin{array}{l}\text { A partir de material didático previamente } \\
\text { gravado, houve produção oral da tonicidade } \\
\text { da sílaba e das sentenças, e do ritmo e da } \\
\text { entonação da língua inglesa. }\end{array}$ & $\begin{array}{l}\text { Laboratório } \\
\text { de Línguas }\end{array}$ & 2 aulas \\
\hline $\begin{array}{l}\text { Leitura oral do } \\
\text { texto } \\
\text { (Lista de compras) }\end{array}$ & $\begin{array}{l}2^{\mathrm{a}} \text { gravação do texto - com treino realizado } \\
\text { pela professora anterior a gravação. }\end{array}$ & $\begin{array}{l}\text { Laboratório } \\
\text { de Línguas }\end{array}$ & 2 aulas \\
\hline
\end{tabular}




\section{Anexo G - Análise com 'Test T' - Padrão Silábico 'VC'}

- 'VC'

Paired Samples Statistics

\begin{tabular}{|l|r|r|r|r|}
\hline Coleta & Média & N & $\begin{array}{l}\text { Desvio } \\
\text { Padrão }\end{array}$ & $\begin{array}{l}\text { Erro Padrão } \\
\text { da Média }\end{array}$ \\
\hline Primeira & 1,8444 & 45,0000 & 0,6014 & 0,0896 \\
\hline Segunda & 0,7556 & 45,0000 & 0,7433 & 0,1108 \\
\hline
\end{tabular}

Paired Samples Correlation (Pearson Coefficient)

\begin{tabular}{|l|r|r|r|}
\hline Coleta & N & Correlação & Significância \\
\hline Primeira e Segunda & 45,0000 & 0,4210 & 0,0040 \\
\hline
\end{tabular}

Paired Samples Test

\begin{tabular}{|l|l|l|l|l|l|l|l|l|}
\hline Coleta & Média & $\begin{array}{l}\text { Desvio } \\
\text { Padrão }\end{array}$ & $\begin{array}{l}\text { Erro } \\
\text { Padrão } \\
\text { da Média }\end{array}$ & \multicolumn{2}{|l|}{$\begin{array}{l}\text { Intervalo de } \\
\text { confiança =95\% }\end{array}$} & $\mathbf{t}$ & $\begin{array}{l}\text { Grau de } \\
\text { Liberdade }\end{array}$ & $\begin{array}{l}\text { Valor de } \\
\text { significância }\end{array}$ \\
\hline & & & & Lower & Upper & & & \\
\hline $\begin{array}{l}\text { Primeira e } \\
\text { Segunda }\end{array}$ & 1,08889 & 0,73306 & 0,10928 & 0,86865 & 1,30912 & $\mathbf{9 , 9 6 4}$ & 44 & 0 \\
\hline
\end{tabular}

Resultado do teste t para amostras emparelhadas:

Se valor de significância $<0,05$ a Hipótese é rejeitada.

- ' $(V C) V C$ '

Paired Samples Statistics

\begin{tabular}{|l|l|r|r|r|r|}
\hline & Coleta & Média & N & $\begin{array}{l}\text { Desvio } \\
\text { Padrão }\end{array}$ & $\begin{array}{l}\text { Erro Padrão } \\
\text { da Média }\end{array}$ \\
\hline Pair 1 & Primeira & 0,0444 & 45,0000 & 0,2084 & 0,0311 \\
\hline & Segunda & 0,0222 & 45,0000 & 0,1491 & 0,0222 \\
\hline
\end{tabular}

Paired Samples Correlation (Pearson Coefficient)

\begin{tabular}{|l|l|l|r|r|}
\hline & Coleta & N & Correlação & Significância \\
\hline Pair 1 & Primeira e Segunda & 45 & $-0,033$ & 0,832 \\
\hline
\end{tabular}

Paired Samples Test

\begin{tabular}{|l|l|l|l|l|l|l|l|l|r|}
\hline & Coleta & Média & $\begin{array}{l}\text { Desvio } \\
\text { Padrã } \\
\text { o }\end{array}$ & $\begin{array}{l}\text { Erro } \\
\text { Padrão } \\
\text { da Média }\end{array}$ & \multicolumn{2}{|l|}{$\begin{array}{l}\text { Intervalo de } \\
\text { confiança } \\
\text { =95\% }\end{array}$} & $\mathbf{t}$ & $\begin{array}{l}\text { Grau de } \\
\text { Liberdad } \\
\text { e }\end{array}$ & $\begin{array}{l}\text { Valor de } \\
\text { significância }\end{array}$ \\
\hline & & & & & Lower & Upper & & & \\
\hline $\begin{array}{l}\text { Pair } \\
\mathbf{1}\end{array}$ & $\begin{array}{l}\text { Primeira e } \\
\text { Segunda }\end{array}$ & 0,0222 & 0,2602 & 0,0388 & $-0,0559$ & 0,1004 & $\begin{array}{r}\mathbf{0 , 5 7 3} \\
\mathbf{0}\end{array}$ & 44,0000 & $\mathbf{0 , 5 7 0 0}$ \\
\hline
\end{tabular}

Resultado do teste t para amostras emparelhadas:

Se valor de significância $<0,05$ a Hipótese é rejeitada. 
- Total: ' $V C$ '

Paired Samples Statistics

\begin{tabular}{|rr|r|r|r|r|}
\hline & & Média & N & Desvio padrão & Erro padrão da média \\
\hline Pair 1 & Tot VC 1a & 1,8889 & 45,0000 & 0,6475 & 0,0965 \\
& Tot VC 2a & 0,7778 & 45,0000 & 0,7654 & 0,1141 \\
\hline
\end{tabular}

Paired Samples Correlation (Pearson Coefficient)

\begin{tabular}{|l|l|r|r|r|}
\hline & Coleta & N & Correlação & Significância \\
\hline Pair 1 & Tot VC 1a e Tot VC 2a & 45 & 0,408 & 0,005 \\
\hline
\end{tabular}

Paired Samples Test

\begin{tabular}{|l|l|l|l|l|l|l|l|l|l|}
\hline & Coleta & Média & $\begin{array}{l}\text { Desvio } \\
\text { Padrã } \\
\mathbf{0}\end{array}$ & $\begin{array}{l}\text { Erro } \\
\text { Padrão } \\
\text { da Média }\end{array}$ & $\begin{array}{l}\text { Intervalo de } \\
\text { confiança } \\
\text { =95\% }\end{array}$ & $\mathbf{t}$ & $\begin{array}{l}\text { Grau de } \\
\text { Liberdad } \\
\mathbf{e}\end{array}$ & $\begin{array}{l}\text { Valor de } \\
\text { significância }\end{array}$ \\
\hline & & & & & Lower & Upper & & & \\
\hline $\begin{array}{l}\text { Pair } \\
\mathbf{1}\end{array}$ & $\begin{array}{l}\text { Tot VC 1a e } \\
\text { Tot VC 2a }\end{array}$ & 1,1111 & 0,7753 & 0,1156 & 0,8782 & 1,3440 & $\begin{array}{r}\mathbf{9 , 6 1 4} \\
\mathbf{0}\end{array}$ & 44,0000 & $\mathbf{0 , 0 0 0 0}$ \\
\hline
\end{tabular}

Hipótese inicial Rejeitada.

Se valor de significância $<0,05$ houve mudanças entre a primeira e a segunda coletas. 


\section{Anexo H - Análise com 'Test T' - Padrão Silábico 'CVC'}

- 'CVC'

Paired Samples Statistics

\begin{tabular}{|l|r|r|r|r|}
\hline Coleta & Média & $\mathbf{N}$ & $\begin{array}{l}\text { Desvio } \\
\text { Padrão }\end{array}$ & $\begin{array}{l}\text { Erro Padrão } \\
\text { da Média }\end{array}$ \\
\hline Primeira & 5,2000 & 45,0000 & 2,3316 & 0,3476 \\
\hline Segunda & 2,1778 & 45,0000 & 1,7747 & 0,2646 \\
\hline
\end{tabular}

Paired Samples Correlation (Pearson Coefficient)

\begin{tabular}{|l|r|r|r|}
\hline Coleta & N & Correlação & Significância \\
\hline Primeira e Segunda & 45,0000 & 0,612 & 0,000 \\
\hline
\end{tabular}

Paired Samples Test

\begin{tabular}{|l|l|l|l|r|r|l|l|l|}
\hline Coleta & Média & $\begin{array}{l}\text { Desvio } \\
\text { Padrão }\end{array}$ & $\begin{array}{l}\text { Erro } \\
\text { Padrão } \\
\text { da Média }\end{array}$ & \multicolumn{2}{|l|}{$\begin{array}{l}\text { Intervalo de } \\
\text { confiança =95\% }\end{array}$} & $\mathbf{t}$ & $\begin{array}{l}\text { Grau de } \\
\text { Liberdade }\end{array}$ & $\begin{array}{l}\text { Valor de } \\
\text { significância }\end{array}$ \\
\hline & & & & Lower & Upper & & & \\
\hline $\begin{array}{l}\text { Primeira e } \\
\text { Segunda }\end{array}$ & 3,0222 & 1,8768 & 0,2798 & 2,4584 & 3,5861 & $\# \# \#$ & 44,0000 & $\mathbf{0 , 0 0 0 0}$ \\
\hline
\end{tabular}

Resultado do teste $t$ para amostras emparelhadas:

Se valor de significância $<0,05$ a Hipótese é rejeitada.

- '(VC)CVC'

Paired Samples Statistics

\begin{tabular}{|l|l|r|r|r|r|}
\hline & Coleta & Média & N & $\begin{array}{l}\text { Desvio } \\
\text { Padrão }\end{array}$ & $\begin{array}{l}\text { Erro Padrão } \\
\text { da Média }\end{array}$ \\
\hline Pair 1 & Primeira & 0,8222 & 45,0000 & 0,3867 & 0,0576 \\
\hline & Segunda & 0,5333 & 45,0000 & 0,5045 & 0,0752 \\
\hline
\end{tabular}

Paired Samples Correlation (Pearson Coefficient)

\begin{tabular}{|l|l|l|r|r|}
\hline & Coleta & N & Correlação & Significância \\
\hline Pair 1 & Primeira e Segunda & 45,0000 & 0,4970 & 0,0010 \\
\hline
\end{tabular}

Paired Samples Test

\begin{tabular}{|l|l|l|l|l|r|r|r|r|r|}
\hline & Coleta & Média & $\begin{array}{l}\text { Desvio } \\
\text { Padrã } \\
\text { o }\end{array}$ & $\begin{array}{l}\text { Erro } \\
\text { Padrão } \\
\text { da Média }\end{array}$ & \multicolumn{2}{|l|}{$\begin{array}{l}\text { Intervalo de } \\
\text { confiança =95\% }\end{array}$} & t & $\begin{array}{l}\text { Grau de } \\
\text { Liberdad } \\
\text { e }\end{array}$ & $\begin{array}{l}\text { Valor de } \\
\text { significância }\end{array}$ \\
\hline $\begin{array}{l}\text { Pair } \\
\mathbf{1}\end{array}$ & $\begin{array}{l}\text { Primeira e } \\
\text { Segunda }\end{array}$ & 0,2889 & 0,45837 & 0,06833 & $\begin{array}{r}0,1511 \\
8\end{array}$ & 0,4266 & $\begin{array}{r}\mathbf{4 , 2 2 8} \\
\mathbf{0}\end{array}$ & 44,0000 & $\mathbf{0 , 0 0 0 0}$ \\
\hline
\end{tabular}

Resultado do teste t para amostras emparelhadas:

Se valor de significância $<0,05$ a Hipótese é rejeitada. 
- '(CV)CVC'

Paired Samples Statistics

\begin{tabular}{|l|l|r|r|r|r|}
\hline & Coleta & Média & N & $\begin{array}{l}\text { Desvio } \\
\text { Padrão }\end{array}$ & $\begin{array}{l}\text { Erro Padrão } \\
\text { da Média }\end{array}$ \\
\hline Pair 1 & Primeira & 0,1556 & 45,0000 & 0,4240 & 0,0632 \\
\hline & Segunda & 0,0222 & 45,0000 & 0,1491 & 0,0222 \\
\hline
\end{tabular}

Paired Samples Correlation (Pearson Coefficient)

\begin{tabular}{|l|l|l|r|r|}
\hline & Coleta & N & Correlação & Significância \\
\hline Pair 1 & Primeira e Segunda & 45,0000 & 0,3040 & 0,0430 \\
\hline
\end{tabular}

Paired Samples Test

\begin{tabular}{|l|l|l|l|l|l|l|l|l|r|}
\hline & Coleta & Média & $\begin{array}{l}\text { Desvio } \\
\text { Padrã } \\
\text { o }\end{array}$ & $\begin{array}{l}\text { Erro } \\
\text { Padrão } \\
\text { da Média }\end{array}$ & \multicolumn{2}{|l|}{$\begin{array}{l}\text { Intervalo de } \\
\text { confiança } \\
\text { =95\% }\end{array}$} & $\mathbf{t}$ & $\begin{array}{l}\text { Grau de } \\
\text { Liberdad } \\
\text { e }\end{array}$ & $\begin{array}{l}\text { Valor de } \\
\text { significância }\end{array}$ \\
\hline & & & & & Lower & Upper & & & \\
\hline $\begin{array}{l}\text { Pair } \\
\mathbf{1}\end{array}$ & $\begin{array}{l}\text { Primeira e } \\
\text { Segunda }\end{array}$ & 0,1333 & 0,4045 & 0,0603 & 0,0118 & 0,2549 & $\begin{array}{r}\mathbf{2 , 2 1 1} \\
\mathbf{0}\end{array}$ & 44,0000 & $\mathbf{0 , 0 3 2 0}$ \\
\hline
\end{tabular}

Resultado do teste $t$ para amostras emparelhadas:

Se valor de significância $<0,05$ a Hipótese é rejeitada.

- '(CVCV)CVC'

Paired Samples Statistics

\begin{tabular}{|l|l|r|r|r|r|}
\hline & Coleta & Média & N & $\begin{array}{l}\text { Desvio } \\
\text { Padrão }\end{array}$ & $\begin{array}{l}\text { Erro Padrão } \\
\text { da Média }\end{array}$ \\
\hline Pair 1 & Primeira & 0,0222 & 45,0000 & 0,1491 & 0,0222 \\
\hline & Segunda & 0,0000 & 45,0000 & 0,0000 & 0,0000 \\
\hline
\end{tabular}

Paired Samples Correlation (Pearson Coefficient)

\begin{tabular}{|l|l|l|l|l|}
\hline & Coleta & N & Correlação & Significância \\
\hline Pair 1 & Primeira e Segunda & 45,0000 & & \\
\hline
\end{tabular}

Paired Samples Test
\begin{tabular}{|l|l|l|l|l|l|l|l|l|l|}
\hline & Coleta & Média & $\begin{array}{l}\text { Desvio } \\
\text { Padrã } \\
\text { o }\end{array}$ & $\begin{array}{l}\text { Erro } \\
\text { Padrão } \\
\text { da Média }\end{array}$ & \multicolumn{2}{|l|}{$\begin{array}{l}\text { Intervalo de } \\
\text { confiança } \\
=95 \%\end{array}$} & $\mathbf{t}$ & $\begin{array}{l}\text { Grau de } \\
\text { Liberdad } \\
\text { e }\end{array}$ & $\begin{array}{l}\text { Valor de } \\
\text { significância }\end{array}$ \\
\hline & & & & & Lower & Upper & & & \\
\hline $\begin{array}{l}\text { Pair } \\
\mathbf{1}\end{array}$ & $\begin{array}{l}\text { Primeira e } \\
\text { Segunda }\end{array}$ & 0,0222 & 0,1491 & 0,0222 & $-0,0226$ & 0,0670 & $\begin{array}{r}\mathbf{1 , 0 0 0} \\
\mathbf{0}\end{array}$ & 44,0000 & $\mathbf{0 , 3 2 3 0}$ \\
\hline
\end{tabular}

Resultado do teste $t$ para amostras emparelhadas:

Se valor de significância $<0,05$ a Hipótese é rejeitada. 
- Total: 'CVC'

Paired Samples Statistics

\begin{tabular}{|rr|r|r|r|r|}
\hline & & Média & N & Desvio padrão & Erro padrão da média \\
\hline Pair 1 & Tot CVC 1a & 6,2000 & 45,0000 & 2,5549 & 0,3809 \\
& Tot CVC 2a & 2,7333 & 45,0000 & 2,0271 & 0,3022 \\
\hline
\end{tabular}

Paired Samples Correlation (Pearson Coefficient)

\begin{tabular}{|l|l|r|r|r|}
\hline & Coleta & N & Correlação & Significância \\
\hline Pair 1 & Tot CVC 1a e Tot CVC 2a & 45 & 0,6070 & 0,000 \\
\hline
\end{tabular}

Paired Samples Test

\begin{tabular}{|l|l|l|l|l|l|l|l|l|l|}
\hline & Coleta & Média & $\begin{array}{l}\text { Desvio } \\
\text { Padrão }\end{array}$ & $\begin{array}{l}\text { Erro } \\
\text { Padrão } \\
\text { da } \\
\text { Média }\end{array}$ & \multicolumn{2}{l}{$\begin{array}{l}\text { Intervalo de } \\
\text { confiança } \\
\mathbf{= 9 5 \%}\end{array}$} & $\mathbf{t}$ & $\begin{array}{l}\text { Grau de } \\
\text { Liberdade }\end{array}$ & $\begin{array}{l}\text { Valor de } \\
\text { significância }\end{array}$ \\
\hline & & & & & Lower & Upper & & & \\
\hline $\begin{array}{l}\text { Pair } \\
\mathbf{1}\end{array}$ & $\begin{array}{l}\text { Tot CVC 1a e } \\
\text { Tot CVC 2a }\end{array}$ & 3,4667 & 2,0846 & 0,3108 & 2,8404 & 4,0929 & $\mathbf{1 1 , 1 5 6 0}$ & 44,0000 & $\mathbf{0 , 0 0 0 0}$ \\
\hline
\end{tabular}

Hipótese inicial Rejeitada.

Se valor de significância $<0,05$ houve mudanças entre a primeira e a segunda coletas. 


\section{Anexo I - Proporcionalidade 'VC' e 'CVC'}

- Proporcionalidade 'VC' e 'CVC' - 1a. coleta

Paired Samples Statistics

\begin{tabular}{|ll|r|r|r|r|}
\hline & & Média & N & Desvio padrão & Erro padrão da média \\
\hline Pair 1 & VC(5) 1a & 1,8889 & 45,0000 & 0,5730 & 0,0854 \\
& CVC(42) 1a & 6,2000 & 45,0000 & 2,5549 & 0,3809 \\
\hline
\end{tabular}

Paired Samples Correlation (Pearson Coefficient)

\begin{tabular}{|l|l|l|r|r|}
\hline & Coleta & N & Correlação & Significância \\
\hline Pair 1 & VC(5) 1a e CVC(42) 1a & 45,0000 & 0,4500 & 0,0020 \\
\hline
\end{tabular}

Paired Samples Test

\begin{tabular}{|l|l|l|l|l|l|l|l|l|l|}
\hline & Coleta & Média & $\begin{array}{l}\text { Desvio } \\
\text { Padrã } \\
\text { o }\end{array}$ & $\begin{array}{l}\text { Erro } \\
\text { Padrão } \\
\text { da Média }\end{array}$ & $\begin{array}{l}\text { Intervalo de } \\
\text { confiança } \\
=95 \%\end{array}$ & $\mathbf{t}$ & $\begin{array}{l}\text { Grau de } \\
\text { Liberda- } \\
\text { de }\end{array}$ & $\begin{array}{l}\text { Valor de } \\
\text { significância }\end{array}$ \\
\hline & & & & & Lower & Upper & & & \\
\hline $\begin{array}{l}\text { Pair } \\
\mathbf{1}\end{array}$ & $\begin{array}{l}\text { VC(5) 1a e } \\
\text { CVC(42) 1a }\end{array}$ & $-4,3111$ & 2,3532 & 0,3508 & $-5,0181$ & $-3,6041$ & $-12,2900$ & 44,0000 & 0,0000 \\
\hline
\end{tabular}

Hipótese Rejeitada.

Como a significância foi menor que a hipótese indica que houve significado entre as coletas.

- Proporcionalidade 'VC' e 'CVC' - 2a. coleta

Paired Samples Statistics

\begin{tabular}{|ll|r|r|r|r|}
\hline & & Média & N & Desvio padrão & Erro padrão da média \\
\hline Pair 1 & VC(5) 2a & 0,7778 & 45,0000 & 0,7654 & 0,1141 \\
& CVC(42) 2a & 2,7333 & 45,0000 & 2,0271 & 0,3032 \\
\hline
\end{tabular}

Paired Samples Correlation (Pearson Coefficient)

\begin{tabular}{|l|l|l|r|r|}
\hline & Coleta & N & Correlação & Significância \\
\hline Pair 1 & VC(5) 2a e CVC(42) 2a & 45,0000 & 0,2830 & 0,0590 \\
\hline
\end{tabular}

Paired Samples Test

\begin{tabular}{|l|l|l|l|l|l|l|l|l|l|}
\hline & Coleta & Média & $\begin{array}{l}\text { Desvio } \\
\text { Padrã } \\
\mathbf{0}\end{array}$ & $\begin{array}{l}\text { Erro } \\
\text { Padrão } \\
\text { da Média }\end{array}$ & $\begin{array}{l}\text { Intervalo de } \\
\text { confiança } \\
=95 \%\end{array}$ & $\mathbf{t}$ & $\begin{array}{l}\text { Grau de } \\
\text { Liberda- } \\
\text { de }\end{array}$ & $\begin{array}{l}\text { Valor de } \\
\text { significân- } \\
\text { cia }\end{array}$ \\
\hline & & & & & Lower & Upper & & & \\
\hline $\begin{array}{l}\text { Pair } \\
\mathbf{1}\end{array}$ & $\begin{array}{l}\text { VC(5) 2a e } \\
\text { CVC(42) 2a }\end{array}$ & $-1,9556$ & 1,9535 & 0,2912 & $-2,5425$ & $-1,3687$ & $-6,7150$ & 44,0000 & 0,0000 \\
\hline
\end{tabular}

Hipótese Rejeitada.

Como a significância foi menor que a hipótese indica que houve significado entre as coletas. 